\title{
Relação entre demandas coletivas, com ênfase no dano ambiental
}

Dissertação apresentada à Faculdade de Direito da Universidade de São Paulo USP, na área de concentração de Direito Processual, como requisito para obtenção do título de Mestre.

Orientador: Prof. Dr. Rodolfo de Camargo Mancuso 


\section{AGRADECIMENTOS}

Muitas foram as pessoas que contribuíram para que o presente trabalho se concretizasse. A todas elas devo meus sinceros agradecimentos.

De início, agradeço ao meu orientador, Professor Doutor Rodolfo de Camargo Mancuso. A admiração que eu já nutria por ele, enquanto doutrinador, só aumentou ao longo desses três anos de convivência. Os ensinamentos foram vários e não se limitaram ao Direito Processual Coletivo. Foi um verdadeiro privilégio ser sua orientanda.

Agradeço, também, aos Professores Carlos Alberto de Salles e Walter Santin, que muito contribuíram para a configuração final do trabalho, por ocasião do exame de qualificação. Igualmente, sou grata aos Professores Ada Pellegrini Grinover, Kazuo Watanabe e ao já citado Carlos Alberto de Salles, pelas inesquecíveis aulas ministradas nas disciplinas Processos Coletivos I e II. Expresso, ainda, meus agradecimentos aos Professores José Rogério Cruz e Tucci e Ricardo de Barros Leonel, que permitiram uma melhor compreensão da "teoria da identidade da relação jurídica".

À amiga do coração Joana Setzer, por seus valiosos conselhos, pelas substanciosas revisões e pelas longas conversas via Skype, o meu 'muito obrigada'. Agradeço, também, à minha tão querida amiga Eduarda Passarelli Hamann-Nielebock, que me ajudou com dicas e conselhos próprios de quem vive intensamente o mundo acadêmico.

Aos amigos Gustavo Milaré e Priscila Artigas, agradeço por toda a ajuda dispensada, desde a época do ingresso no mestrado, até a data de depósito da dissertação. Agradeço, também, ao amigo Rodrigo Barioni, por todas as dicas "processualísticas".

Meus agradecimentos, ainda, ao Yuri Marinho e à Aline Bevenuto, do escritório Pires Castanho Advogados | Consultoria Ambiental, que me auxiliaram na conciliação do mestrado com a advocacia. 
Meu especial agradecimento aos meus pais, Eduardo e Silvia, não só por servirem de exemplo e inspiração, mas por terem me apoiado em mais esta importante decisão.

Acima de tudo, agradeço ao meu marido, Daniel Russo Checchinato, que tanto me ajudou e me apoiou, desde o início desta jornada, discutindo questões jurídicas, auxiliando na estruturação dos tópicos, fazendo a revisão final do trabalho e - por que não dizer? agüentando as minhas mudanças de humor... Obrigada, meu amor. 


\section{RESUMO}

O presente trabalho tem por escopo analisar a possibilidade de aplicação, nos processos coletivos, dos atuais institutos do Direito de Processual Civil, criados para solucionar os problemas decorrentes da relação entre demandas intersubjetivas, i.e., conexão, continência, litispendência e coisa julgada.

Devido às características intrínsecas dos interesses metaindividuais, a propositura de mais de uma demanda coletiva, por diferentes legitimados ativos, todas com efeitos erga omnes e objeto indivisível, pode levar à prolação de comandos contraditórios, com desdobramentos no plano prático, podendo gerar situações insustentáveis especificamente nos conflitos ambientais, dado o caráter difuso do bem tutelado.

Diante das peculiaridades dos processos coletivos, o legislador e os operadores do direito podem optar por um de dois caminhos: adotar o sistema tradicional ou inovar. O presente trabalho propõe a inovação, a modernização, a adequação, a adaptação, enfim, a flexibilização dos institutos processuais clássicos - sem a pretensão de formular qualquer resposta definitiva. As inovações aqui propostas iniciam-se pelo próprio conceito de identidade de ações, perpassando por uma releitura dos elementos objetivos da demanda (pedido e causa de pedir), com foco no bem jurídico tutelado e no resultado prático visado pelos processos. Na seqüência, os institutos conexão, continência, litispendência e coisa julgada são revisitados, adaptando-se às necessidades da jurisdição coletiva.

Em suma, o trabalho conclui que a transposição, sic et simpliciter, dos institutos processuais clássicos voltados à relação entre demandas individuais para o plano da jurisdição coletiva não é cabível, sendo necessário flexibilizar e modernizar algumas figuras, com vistas a impedir que a mesma situação de fato receba tratamentos diferenciados em duas ou mais demandas. Tudo em prol da efetividade do processo coletivo e dos princípios da economia processual, da isonomia e da certeza das relações jurídicas.

PALAVRAS-CHAVE: pedido e causa de pedir, processos coletivos, meio ambiente, flexibilização, conexão e litispendência. 


\begin{abstract}
The scope of this study is to analyze the possibility of applying, in collective lawsuits, the current tools of the Civil Procedural Law, created to solve problems arising out of the relation between inter-subjective claims (i.e. same cause of action, encompassing lawsuit, collateral estoppel and res judicata).
\end{abstract}

Due to the intrinsic characteristics of the meta-individual interests, the proposal of another collective claim, by different parties, all with erga omnes effect and indivisible object, may lead to the issuance of contradictory orders, affecting its practical aspect, and possibly generating unsustainable situations - specifically in environmental conflicts, due to the public nature of the matter.

Given the peculiarities of collective claims, legislators and Law operators may decide to adopt either the traditional system, or innovate. This paper proposes innovating, updating, adequating and adapting the classical procedural tools - with no intention of reaching a definitive answer. The innovations proposed herein start by the identity of action concept itself, revisiting the objective elements of the claim (pleading and cause of action), focusing on the core of the matter and on the practical result sought by the lawsuits. Subsequently, tools such as same cause of action, encompassing lawsuit, collateral estoppel and res judicata are also revisited, adapting to the needs of collective jurisdiction.

In short, this study concludes that transferring, sic et simpliciter, the classic procedural tools regarding the relations between individual claims to the collective jurisdiction is not possible, being necessary to adapt/update some concepts, so that the expected result is reached, preventing the same situation in fact is treated differently in two or more claims (on behalf of the effectiveness of the collective lawsuit and of the principles of the procedural economy, the isonomy and the certainty of the legal relations).

KEYWORDS: pleading and cause of action, collective lawsuits, environment, adaptation, same cause of action and collateral estoppel. 


\section{SUMÁRIO}

Introdução. .09

Capítulo I - A sistemática do Código de Processo Civil para solução dos problemas decorrentes da relação entre demandas intersubjetivas

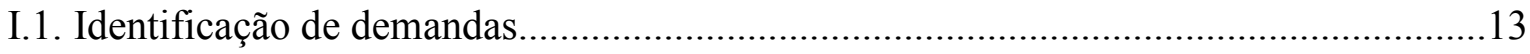

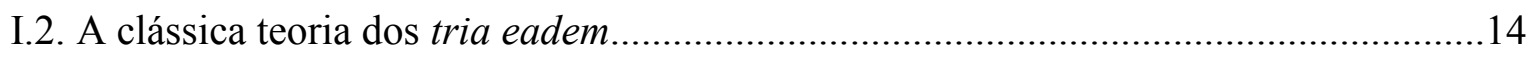

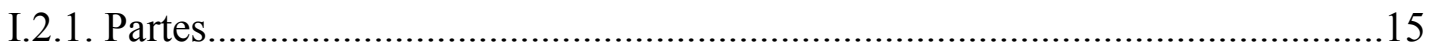

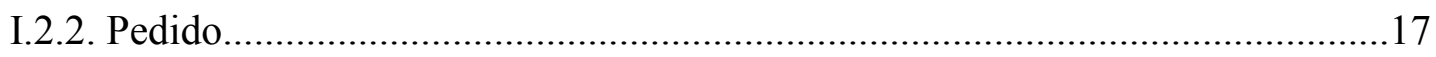

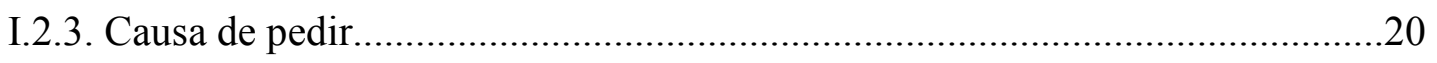

I.2.3.1. Objeto do processo (Streitgegenstand).........................................21

I.2.3.2. O que compõe a causa petendi? ...................................................24

I.2.3.2.1. Teoria da substanciação.......................................................25

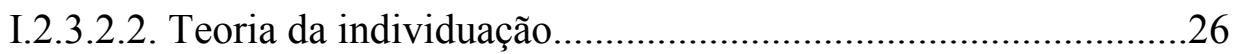

I.2.3.2.3. Importância do tema: estabilização da demanda......................27

I.2.3.2.4. Proposta de aproximação.....................................................29

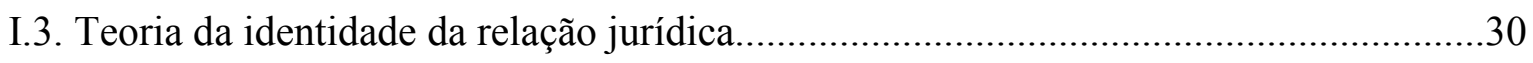

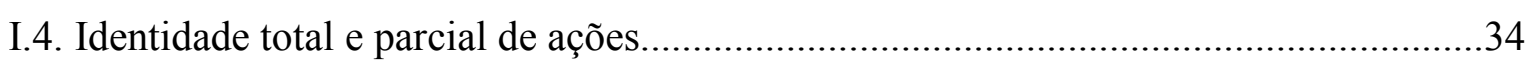

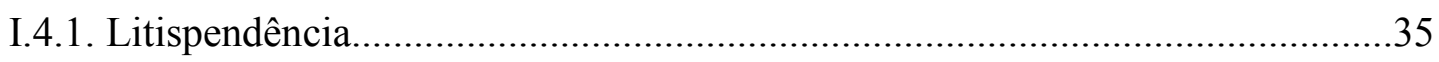

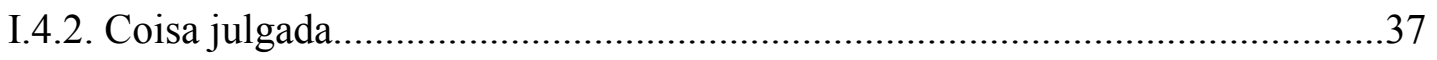

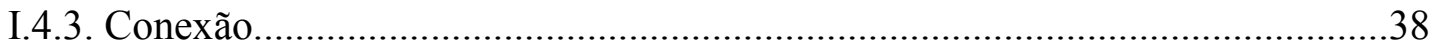

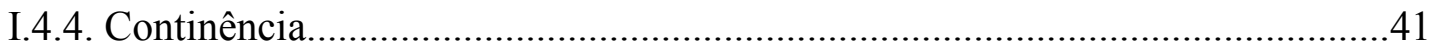

\section{Capítulo II - Aspectos intrínsecos da Jurisdição Coletiva}

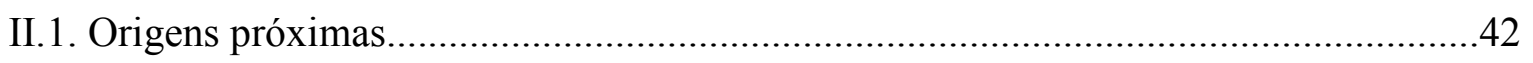

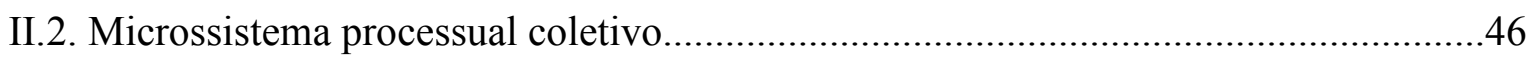

II.3. Visão geral sobre os interesses metaindividuais: Difusos $x$ Coletivos (stricto sensu) $x$

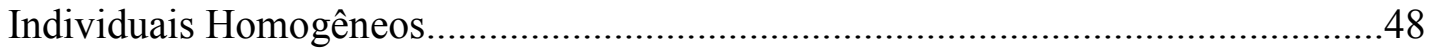

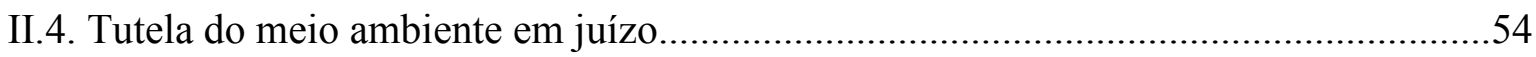

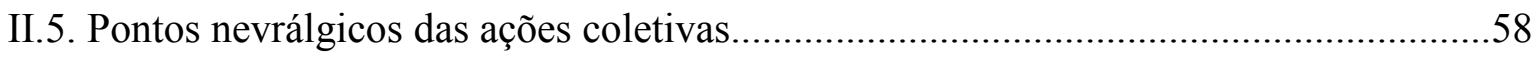


II.5.1. Legitimação para agir .58

II.5.2. Indivisibilidade do objeto 63

II.5.3. Coisa julgada .65

II.5.3.1. Coisa julgada nos direitos difusos. .67

II.5.3.2. Coisa julgada nos direitos coletivos (stricto sensu). 68

II.5.3.3. Coisa julgada nos direitos individuais homogêneos .69

II.6. A Lei n. 9.494/97. .72

II.6.1. Evolução histórica. .72

II.6.2. Involução histórica. .74

II.6.3. Disciplina da competência. .75

II.6.4. Inoperância da Lei n. 9.494/97 nas ações ambientais.....................................78

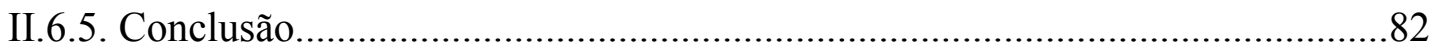

II.6.6. O conflito de competência n. 47731/DF..........................................................84

II.7. Efetividade do processo coletivo. 85

\section{Capítulo III - Relação entre Demandas Coletivas}

III.1. Problemas decorrentes da concomitância/concorrência de ações coletivas.................93

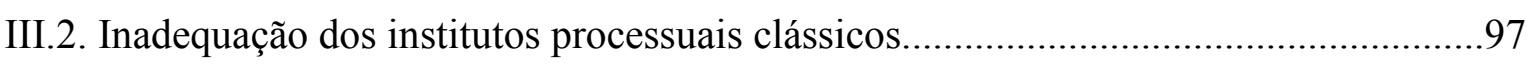

III.2.1. Necessidade de flexibilização das regras processuais...................................99

III.2.1.1. Instrumentalidade do processo e instrumentalidade das formas......101

III.3. Teoria da tríplice identidade obtemperada pela teoria da identidade da relação jurídica..... 104

III.4. Elemento subjetivo: irrelevância da identidade física do legitimado.........................106

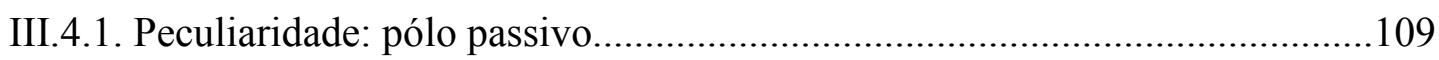

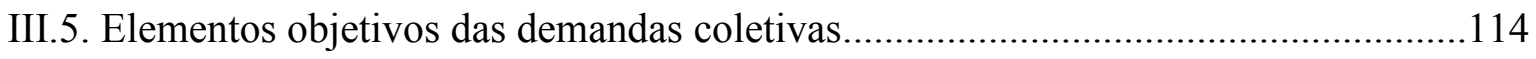
III.5.1. Foco no núcleo essencial / no thema decidendum / no bem jurídico coletivo /

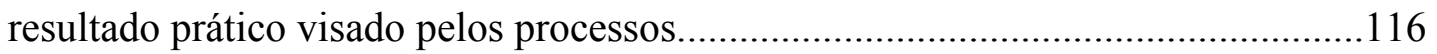

III.5.2. Interpretação extensiva da causa de pedir remota e do pedido mediato........121

III.5.3. Causa de pedir próxima e pedido imediato: elementos secundários..............126

III.6. Conclusão Preliminar: Identidade de seis elementos $x$ semelhança de dois

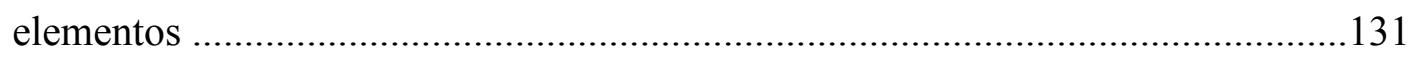

III.7. Ações coletivas $x$ ações individuais: exceção que confirma a regra..........................135

III.7.1. Peculiaridade: Ações pseudo-individuais 141 


\section{Capítulo IV - Possíveis soluções para o conflito}

IV.1. Qual a solução para o conflito?

IV.1.1. Reunião para julgamento conjunto (conexão/continência).............................145

IV.1.2. Extinção das demandas subseqüentes (litispendência/coisa julgada)............149

IV.1.2.1. Molecularização = uma única demanda.............................159

IV.1.2.2. Proposta de solução: possibilidade de ampliação da primeira

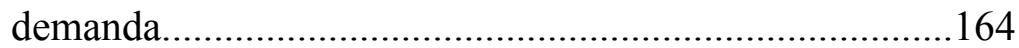

IV.1.2.3. Nova equação das regras de estabilização da demanda. 166

IV.1.3. A relação entre demandas coletivas no ANTEPROJETO DA USP e na Proposta do MinISTÉRIO DA JUSTIÇA.......................................................171

Conclusão 174 


\section{INTRODUÇÃO}

O presente trabalho tem por objeto a Relação entre Demandas Coletivas, com ênfase no dano ambiental, e, como escopo, a análise da efetividade da aplicação, nos processos coletivos, dos atuais institutos do Direito de Processual Civil, criados para solucionar os problemas decorrentes da relação entre demandas intersubjetivas.

No plano da jurisdição singular, o Código de Processo Civil soluciona essa questão de maneira razoavelmente eficaz, por meio dos institutos da conexão, continência, litispendência e coisa julgada. Para tanto, é necessário identificar as demandas, o que, via de regra, se faz por meio dos seus elementos constitutivos: partes, causa de pedir e pedido. Mas, na linha do que propõem alguns processualistas, mais importante do que identificar os elementos da ação é saber o resultado prático visado pelo processo, considerando que a teoria dos tria eadem nem sempre se mostra suficiente para delimitar, com precisão, o âmbito de incidência do impedimento causado pela litispendência.

O que já vem sendo proposto no processo civil individual ganha maior relevância no plano da jurisdição coletiva, tendo em vista que aqui o problema se apresenta de forma muito mais complexa. De fato, as demandas coletivas têm por objeto interesses metaindividuais, que se caracterizam, dentre outros fatores, pela indeterminação dos seus titulares, pela indivisibilidade do seu objeto e por sua alta conflituosidade interna. Diante dessas especificidades, algumas regras de direito positivo e processual foram reestruturadas, com o objetivo de oferecer uma prestação jurisdicional mais completa e adequada.

Neste cenário, destacam-se a Lei n. 4.717/65 (Ação Popular), a Lei n. 7.347/85 (Ação Civil Pública) e a Lei n. 8.078/90 (Código de Defesa do Consumidor), as quais se integram e complementam-se, formando um verdadeiro microssistema processual coletivo, voltado à tutela dos interesses difusos, coletivos e individuais homogêneos. No âmbito desse microssistema, os institutos tradicionais e individualistas do processo civil - 
de resto inadequados à tutela dos interesses metaindividuais - foram modernizados, alterando-se profundamente. Dentre os institutos processuais clássicos que foram flexibilizados, cabe destacar: (i) a legitimação para agir, que passou a ser extraordinária, sob a forma concorrente-disjuntiva, facultando-se a vários co-legitimados a propositura de ação, em nome próprio, no interesse da coletividade; e (ii) a coisa julgada, que tem eficácia erga omnes ou ultra partes, ampliando-se os limites subjetivos do julgado.

Tais peculiaridades, somadas à indivisibilidade do objeto, típica das demandas coletivas, levam à constatação de que a legitimação aberta pode ensejar a propositura de mais de uma ação coletiva por diferentes co-legitimados, todas com efeitos erga omnes e objeto indivisível. Em outras palavras, "a virtual prolação de comandos de conteúdo diverso vai propiciar contradição que não se conterá apenas no plano lógico, mas desdobrará para o plano prático"1.

Com efeito, a concomitância de mais de uma ação coletiva, com objetos idênticos ou semelhantes, pode ocasionar decisões judiciais conflitantes, trazendo insegurança jurídica e ferindo o princípio constitucional da isonomia, acarretando, assim, sérias consequências no campo prático, pois cada uma dessas ações produzirá efeitos sobre toda a coletividade. Para GRINOVER, a multiplicidade de ações coletivas, versando sobre a mesma situação material, pode gerar situações insustentáveis, que põem em sério risco o próprio prestígio do Poder Judiciário ${ }^{2}$.

Com vistas a sanar este tipo de problema, atualmente, socorre-se dos clássicos e individualistas institutos da conexão, continência, litispendência e coisa julgada (valendose, para tanto, exclusivamente da teoria da tríplice identidade), os quais, todavia, não se mostram plenamente adequados para solucionar o problema no âmbito da jurisdição coletiva.

\footnotetext{
${ }^{1}$ MANCUSO, Rodolfo de Camargo. A concomitância de ações coletivas, entre si, e em face das ações individuais. In Revista dos Tribunais, ano 89, v. 782, São Paulo, dez. 2000, p. 38.

${ }^{2}$ GRINOVER, Ada Pellegrini et alii. Código Brasileiro de Defesa do Consumidor comentado pelos autores do Anteprojeto. Rio de Janeiro: Forense Universitária, 2004, p. 940.
} 
No que tange aos elementos pedido e causa de pedir, por exemplo, seus conceitos rígidos têm dificultado a reunião/extinção de processos, provocando a condução fragmentária de demandas, com decisões contraditórias. Verifica-se, a partir dessa constatação, uma necessidade de flexibilizar tais institutos, de tal modo que a atenção do operador do direito passe a recair sobre o bem jurídico a ser protegido. No que diz respeito ao elemento subjetivo, este também deve ser considerado à luz da qualidade jurídica da parte, e não da sua identidade física.

É justamente em função dessas peculiaridades da jurisdição coletiva que o presente trabalho busca questionar se os institutos processuais hoje existentes para a solução dos problemas decorrentes da relação entre demandas são suficientes e adequados para o processo coletivo. Com o intuito de contribuir para o aprimoramento do tema, alguns institutos clássicos do Processo Civil foram repensados, sob o enfoque do Direito Processual Civil Coletivo, ao qual se somam as inovações trazidas pelas propostas de criação de um Código Brasileiro De Processos Coletivos. Toda essa análise tem como foco os conflitos ambientais, delimitando-se o direito material objeto das lides coletivas concomitantes, que se caracteriza por ser tipicamente difuso.

Definido o escopo do trabalho, faz-se uma breve apresentação dos Capítulos que compõem a presente dissertação.

O Capítulo I destina-se a analisar, sinteticamente, a atual sistemática do Código de Processo Civil para solução dos problemas decorrentes da relação entre demandas intersubjetivas, de tal forma que seja possível compreender determinados fenômenos nas ações coletivas. Da mesma forma, é preciso conhecer os institutos clássicos da jurisdição singular para que se possa, mais adiante, avaliar o cabimento do seu traslado para a jurisdição coletiva.

Adentrando nas peculiaridades da jurisdição coletiva, o Capítulo II apresenta os diferentes feixes e características intrínsecas dos interesses metaindividuais, sendo conferido maior destaque aos interesses difusos, eis que o trabalho concentra-se nos conflitos ambientais. $\mathrm{O}$ estudo dessas características mostra-se importante, porque permite uma melhor compreensão das peculiaridades da jurisdição coletiva, o que pode vir a justificar a adaptação de alguns conceitos processuais clássicos. 
Com base nos conceitos explorados nos capítulos anteriores, faz-se um confronto entre os institutos clássicos de lides intersubjetivas e as peculiaridades da jurisdição coletiva, com vistas a investigar a possibilidade ou não de traslado daqueles conceitos para a jurisdição de massa. O Capítulo III aborda, principalmente, o conceito de identidade de ações, flexibilizando sua aplicação no plano da jurisdição coletiva, com ênfase no núcleo essencial da demanda, no thema decidendum, enfim, no bem jurídico tutelado.

O Capítulo IV, por fim, analisa as possíveis soluções práticas para a concomitância/concorrência de demandas coletivas, ponderando prós e contras das duas opções naturais: reunião para julgamento conjunto (conexão) ou extinção das demandas subseqüentes (litispendência).

Como se verá ao longo do presente trabalho, muitas das propostas aqui apresentadas são de lege ferenda, o que, todavia, não retira sua contribuição para o debate, pois é justamente a discussão de idéias, mesmo as polêmicas, que enriquece o cenário acadêmico. Afinal, seguindo o conselho do Professor MANCUSO, "é preferível um trabalho ousado, do que usado". 


\section{CAPÍtulo I - A SISTEMÁtica do Código DE PROCESSO CIVIL PARA SOLUÇÃO DOS PROBLEMAS DECORRENTES DA RELAÇÃO ENTRE DEMANDAS INTERSUBJETIVAS}

\section{I.1. Identificação de demandas}

Há muito os processualistas discorrem sobre o tema identificação de demandas, seja quanto a sua importância e finalidade, seja quanto aos elementos necessários para tanto, seja, ainda, quanto às correntes doutrinárias que tratam do assunto.

A mais abrangente razão de identificar-se uma demanda está na necessidade de estabelecer os limites a serem observados na atividade jurisdicional: o juiz deverá julgar cada demanda "nos limites em que ela tiver sido proposta (art. 128), a saber, para as pessoas ali indicadas, pelos fundamentos lançados na petição inicial e com relação ao bem da vida que o autor declarou pretender" ${ }^{3}$. Além disso, a identificação de demandas também fornece informações para solucionar alguns fenômenos processuais importantes, como a litispendência, a coisa julgada, a conexão e a continência.

Segundo a clássica lição de CHIOVENDA, "conhece-se por identificação das ações a operação por meio da qual se confrontam entre si várias ações com o fim de estabelecer se são idênticas ou diversas"4. O instrumento facilitador dessa operação é a petição inicial, por meio da qual são definidos, pelo autor, os elementos da demanda. Não por outro motivo o Código de Processo Civil (“CPC”), em seu artigo 282, exige que a petição inicial explicite, dentre outros, as partes, autor e réu; os fatos e fundamentos jurídicos do pedido, isto é, a causa petendi; e o pedido, com suas especificações. Uma inicial apta deve oferecer claramente os elementos necessários à identificação da demanda.

\footnotetext{
${ }^{3}$ DINAMARCO, Cândido Rangel. Instituições de Direito Processual Civil. São Paulo: Malheiros, 2005, p. 129, passim.

${ }^{4}$ CHIOVENDA, Giuseppe. Instituições de Direito Processual Civil. MENEGALE, J. Guimarães (Trad.). LIEBMAN, Enrico Tullio (Notas). São Paulo: Saraiva, v. I, 1965, p. 353, passim.
} 
A bem ver, portanto, a finalidade de identificar demandas é permitir a tomada de decisão quanto (i) à reunião dos processos, em atenção à regra da economia processual; ou (ii) à extinção de ações repetitivas, impedindo-se a reprodução simultânea ou sucessiva de ações idênticas. Isso porque, como é notório e intuitivo, "para evitar decisões contraditórias, tem-se que coibir a pendência de ações iguais"

Embora haja consenso quanto à utilidade da identificação, é possível haver alguma divergência quanto aos elementos necessários para tanto: de um lado, a teoria das três identidades propõe que a operação de identificar demandas abranja, necessariamente, seus três elementos individualizadores (partes, pedido e causa de pedir); de outro lado, a teoria da identidade da relação jurídica contenta-se com a individuação da relação jurídica substancial. Segundo CRUZ E TUCCI, as duas teorias precursoras e provenientes das fontes romanas são: “ $a$ ) a da tríplice identidade - pessoas, causa de pedir e pedido; e $b$ ) a da identidade da relação jurídica, a qual, no século passado, encontrou em SAVIGNY o seu grande propagador"6.

Em que pesem as visões extremadas de um ou outro doutrinador, a verdade é que uma teoria não exclui a outra; ao contrário, complementam-se, pois ambas destinam-se a uma única finalidade: "dizer quando o conteúdo de um processo é idêntico ao de outro, para vedar-se a reprodução simultânea ou sucessiva (litispendência ou coisa julgada) de duas demandas, porque isso atenta contra o bom funcionamento da justiça"7.

\section{I.2. A clássica teoria dos tria eadem}

Inicialmente, serão analisados os elementos que compõem a clássica teoria dos tria eadem ou teoria da tríplice identidade. Largamente adotada pela doutrina brasileira, essa teoria fundamenta-se na assertiva de que as ações apresentam três elementos essenciais: partes, causa de pedir e pedido, assim descritos por CHIOVENDA:

\footnotetext{
5 ARRUDA ALVIM. Manual de Direito Processual Civil. São Paulo: Revista dos Tribunais, 1996, v. I, p. 379.

${ }^{6}$ CRUZ E TUCCI, José Rogério. A causa petendi no processo civil. São Paulo: Revista dos Tribunais, 2001, p. 26, passim.

7 ARRUDA ALVIM. Ensaio sobre a litispendência no Direito Processual Civil. São Paulo: Revista dos Tribunais, 1970, v. II, p. 62, passim.
} 
$1^{\circ}$ ) Os sujeitos, isto é, o sujeito ativo (autor), a quem pertence o poder de agir, e o passivo (réu), em face de quem se exerce o poder de agir (personae); $2^{\circ}$ ) A causa da ação, isto é, um estado de fato e de direito, que é a razão pela qual se exerce uma ação, e que habitualmente se cinde, por sua vez, em dois elementos: uma relação jurídica e um estado de fato contrário ao direito (causa petendi); $3^{\circ}$ ) O objeto, isto é, o efeito a que tende o poder de agir. Aquilo que se pede (petitum $)^{8}$.

A alusão aos três elementos está expressa no CPC de 1973, artigo 301, §2º, conforme verbis: "uma ação é idêntica a outra, quando tem as mesmas partes, a mesma causa de pedir e o mesmo pedido". Segundo a teoria da tríplice identidade, para identificarse uma demanda, é necessário saber:

(a) o sujeito que a propõe, (b) aquele em relação ao qual a demanda é proposta, (c) os fatos que o autor alega para demonstrar seu alegado direito, (d) a proposta de enquadramento desses fatos em uma categoria jurídico-material, (e) a postulação de um provimento jurisdicional de determinada natureza e (f) a especificação do concreto bem da vida pretendido ${ }^{9}$.

Confiram-se, um a um, os elementos acima descritos.

\section{I.2.1. Partes}

Na clássica lição de CHIOVENDA, "parte é aquele que demanda em seu próprio nome (ou em cujo nome é demandado) a atuação duma vontade da lei, e aquele em face de quem essa atuação é demandada"10. Para o autor, o conceito de parte está relacionado, unicamente, com a condição de sujeito ativo ou passivo da demanda judicial.

\footnotetext{
${ }^{8}$ CHIOVENDA, Giuseppe. Instituições..., op. cit, v. I, p. 32 e 33.

${ }^{9}$ DINAMARCO, Cândido Rangel. Instituições de Direito Processual Civil. São Paulo: Malheiros, $2005, \mathrm{v}$. II, p. 112.

${ }^{10}$ CHIOVENDA, Giuseppe. Instituições de Direito Processual Civil. MENEGALE, J. Guimarães (Trad.). LIEBMAN, Enrico Tullio (Notas). São Paulo: Saraiva, v.II, 1943, p. 320/321, passim.
} 
Já para LIEBMAN, "são partes do processo os sujeitos do contraditório instituído perante o juiz (os sujeitos do processo diversos do juiz, para os quais este deve proferir o seu provimento)" " 11 A diferença entre ambos os conceitos é facilmente percebida na figura do assistente, por exemplo. Para LIEBMAN, o assistente é parte, porque está em contraditório perante o juiz, ao passo que, para CHIOVENDA, o mesmo raciocínio não se aplica, pois o assistente não pede, nem com relação a ele é pedido ${ }^{12}$.

Pode acontecer de uma pessoa agir, no processo, em nome de outra. Trata-se do instituto da representação (voluntária ou legal). Nesses casos, a parte é o representado e não o representante ${ }^{13}$. De outro lado, também se admite que alguém exerça em nome próprio direito alheio. Trata-se da substituição processual, na qual aquele que ingressa em juízo, o substituto, é que é parte formal no processo ${ }^{14}$.

Em uma visão processualista, portanto, a condição de parte resulta do fato objetivo de estar incluído em uma relação processual, na qualidade de sujeito interessado (parcial). Partes são os titulares de direitos e deveres processuais (situações ativas e passivas inerentes à relação processual), com oportunidade de participação em contraditório perante o juiz. Pouco importa, processualmente falando, se as partes são legítimas ou não, isto é, se as pessoas que figuram no processo correspondem aos titulares da relação jurídicomaterial. A questão da legitimidade diz respeito às condições da ação, fugindo ao escopo do presente tópico, que se cinge ao conceito de parte formal - seja ela legítima ou ilegítima.

Visto isso, cumpre ressaltar que a tarefa de identificar as partes de um litígio (eadem personae) implica perquirir, necessariamente, sua identidade jurídica, analisandose em que qualidade a pessoa apresenta-se no processo $^{15}$ (por qualidade, entenda-se a posição da parte em relação ao bem jurídico objeto da demanda). Daí se dizer que

\footnotetext{
${ }^{11}$ LIEBMAN, Enrico Tullio. Manual de Direito Processual Civil. DINAMARCO, Cândido Rangel (Trad.).. Rio de Janeiro: Forense, 1984, p. 89. No original: "sono parti del processo i soggetti del contraddittorio instituto davanti al giudice, i soggetti del processo diversi dal giudice, nei cui confronti quest'ultimo deve pronunciarei il suo provvedimento" (Manuale di Diritto Processuale Civile. Milano: Dott A. Giuffrè Editore, 1984, p. 75).

${ }^{12}$ Cf. DINAMARCO, Cândido Rangel, Nota 86. In LIEBMAN, Enrico Tullio. Ibidem, p. 115. Mesmo raciocínio é válido para o Ministério Público na condição de custos legis.

${ }^{13}$ Cf. LIEBMAN, Enrico Tullio. Ibidem, p. 90

${ }^{14}$ Cf. CHIOVENDA, Giuseppe. Instituições..., op. cit, v. II, p. 346.

${ }^{15}$ Nesse sentido, ARRUDA ALVIM. Ensaio..., op. cit., v. II, p. 65.
} 
a identidade física da parte não tem relevância, pois nem sempre identidade da pessoa física/natural produz identidade subjetiva de ações.

Nessa linha, CHIOVENDA ressalta a importância da qualidade com que determinada pessoa figure no processo para a identidade subjetiva. Segundo o autor, duas ações só são subjetivamente idênticas quando as partes se apresentam na mesma qualidade. E vice-versa, "a mudança da pessoa física como sujeito de uma ação não tem como conseqüência que o direito trate a ação como diversa" ${ }^{" 16}$. A mudança de pessoa física com manutenção da qualidade no processo ocorre, por exemplo, nos casos de solidariedade, em que a mesma coisa é devida por diversos ou a diversos sujeitos, ou de direitos potestativos correspondentes a diversas pessoas e tendentes à cessação do mesmo estado ou ato jurídico, como ocorre, por exemplo, com o direito de todos os sócios de impugnar as deliberações da assembléia geral ou com o direito à propositura de Ação Popular ${ }^{17}$.

\section{I.2.2. Pedido}

Como o próprio nome já indica, o pedido é aquilo que se pede ao Estado-juiz, constituindo o mérito ou objeto do processo. É no pedido que se identifica a pretensão do autor, no sentido da afirmação do seu direito ${ }^{18}$, a qual, por força do princípio da adstrição ou correlação do julgado, delimitará e definirá os contornos da futura sentença, de forma que o objeto do litígio fique estabelecido, desde logo, pelo próprio autor na petição inicial $^{19}$.

Tradicionalmente, a doutrina qualifica o pedido como imediato e mediato. Para CHIOVENDA:

\footnotetext{
${ }^{16}$ CHIOVENDA, Giuseppe. Instituições..., op. cit., v. I, p. 355/356 (g.n.).

${ }^{17}$ Idem, ibidem, p. 356.

${ }^{18}$ Nesse sentido, ARRUDA ALVIM assevera que "se a pretensão é afirmação de direito, é o pedido uma declaração de vontade, através da qual, enunciado o direito, objetiva-se a respectiva realização ou reconhecimento mercê da ação" (Ensaio..., op. cit., v. II, p. 68).

${ }^{19}$ Importa esclarecer que os fatos constitutivos, modificativos ou extintivos do direito afirmado pelo autor, trazidos pelo réu na contestação, não têm o condão de ampliar ou modificar o pedido, permanecendo inalterado o âmbito dentro do qual toca ao órgão jurisdicional decidir a lide da futura decisão.
} 
O que imediatamente se pede é a atuação da lei, a qual, nas diferentes ações, se apresenta individuada em determinado ato (condenação a restituir o imóvel; condenação a pagar 100; rescisão da venda; declaração de falsidade dum documento). $\mathrm{O}$ objeto, pois, a cuja consecução se coordena a atuação da lei (imóvel a restituir; soma a pagar) denomina-se objeto mediato da ação ${ }^{20}$.

Por igual, BARBOSA MOREIRA ensina que o objeto imediato do pedido é "a providência jurisdicional solicitada (ex: a condenação do réu ao pagamento de $x)^{\text {"21 }}$, enquanto o objeto mediato é "o bem que o autor pretende conseguir por meio dessa providência (ex: a importância $x)^{, 22}$.

Especificamente sobre o pedido mediato, vale salientar que este é o bem jurídico colimado pelo autor, sendo irrelevante a identidade física do bem. "O que se deseja é a sua identidade jurídica, daí dizer-se, ao que nos parece com mais propriedade, bem jurídico" ${ }^{, 23}$. Nas palavras de DINAMARCO, o bem da vida "é o preciso bem que o demandante pretende haver, como resultado final do processo" ${ }^{, 24}$.

A importância do pedido como elemento identificador da demanda é notória, como aponta CHIOVENDA: "lógico é que se deva falar de demanda diversa quando diverso é o bem contestado" 25 . Para que se possa identificar o pedido (eadem res), primeiro, é necessário analisar o ato que ao juiz se pede (pedido imediato). Mas não é só, é preciso analisar, também, o pedido mediato da ação, isto é, o bem garantido pela lei cuja atuação se requer. Conforme a abalizada doutrina de ARRUDA ALVIM,

A identificação de ações (...) baseia-se nas pretensões de ambos os processos, levando-se em consideração, também, o tipo de ação utilizado. Ou seja, baseia-se em duas afirmações de direito (isto é, duas pretensões $)^{26}$.

\footnotetext{
${ }^{20}$ CHIOVENDA, Giuseppe. Instituições..., op. cit., v. I, p. 32 e 33.

21 BARBOSA MOREIRA, José Carlos. O novo processo civil brasileiro: exposição sistemática do procedimento. Rio de Janeiro: Forense, 1999, p. 10.

${ }^{22}$ Idem, ibidem..

${ }^{23}$ ARRUDA ALVIM. Ensaio..., op. cit., v. II, p. 76.

${ }^{24}$ DINAMARCO, Cândido Rangel. Instituições..., op. cit., p. 119.

${ }^{25}$ CHIOVENDA, Giuseppe. Ibidem, p. 360.

${ }^{26}$ ARRUDA ALVIM. Ibidem, p.70.
} 
A guisa de exemplo, saliente-se que nas ações declaratórias e constitutivas, em geral, o pedido imediato coincide com o mediato, pois o autor já se satisfaz com a declaração/constituição. Nas ações condenatórias, ao contrário, é necessário executar a sentença, de modo que o objeto imediato (provimento jurisdicional) não se confunde com o objeto mediato (bem da vida, que se obterá futuramente ao final da execução). Complementando tal raciocínio, DINAMARCO salienta que um pedido é diferente de outro "sempre que em cada um deles se postule uma espécie de provimento, mesmo que ambos se refiram ao mesmo bem da vida (p.ex., a condenação a entregar o bem e a declaração de que o demandante tem direito de propriedade sobre ele)"27.

Não há dúvida, pois, de que o pedido é de altíssima relevância para identificar demandas, uma vez que ele aponta o bem da vida pretendido pelo autor. Mais do que isso. Para muitos autores, o pedido - e só ele - consiste no próprio objeto litigioso do processo, tendo em vista que, no processo civil de resultados, é o acolhimento ou a rejeição do pedido que gera efeitos práticos na vida do autor e do réu ${ }^{28}$. Para os adeptos dessa corrente, os fundamentos de fato e de direito não integram o objeto do processo, limitando-se a auxiliar na construção do raciocínio lógico-jurídico que conduz ao direito afirmado. Por via de conseqüência, a causa de pedir, analisada na motivação da sentença, não fíca imunizada pela coisa julgada material.

Todavia, a questão não é, nem de longe, pacífica, conforme se verá no tópico seguinte. Isso porque "o bem controverso não coincide com o objeto; (...) é necessário saber-se ainda a que título se reclama o objeto e a que utilidade deve servir; porquanto o bem varia em razão do título e da utilidade. A isso atende outro elemento objetivo, a causa" ${ }^{29}$. Vale dizer, o pedido deve decorrer logicamente dos fatos, segundo a roupagem jurídica que o autor lhes houver dado (cf. artigo 295, parágrafo único, II, do CPC).

Por fim, saliente-se que, embora os pedidos imediato e mediato venham delineados na petição inicial e tornem-se imutáveis após a estabilização da demanda (com a citação do réu), a lei faculta sua alteração, desde que isso ocorra antes da citação do réu (art. 264,

\footnotetext{
${ }^{27}$ DINAMARCO, Cândido Rangel. Instituições..., op. cit., p. 118 (grifos no original).

${ }^{28}$ Cf. DINAMARCO, Cândido Rangel. Ibidem, p. 184.

${ }^{29}$ CHIOVENDA, Giuseppe. Instituições..., op. cit., , v. I, p. 357 (g.n.).
} 
caput, do CPC, a contrario sensu) ou, se posterior, com o consentimento deste (art. 264, parágrafo único, do CPC). Nessas hipóteses, no entanto, há de assegurar-se ao réu novo prazo para resposta, “pois, alterado o pedido, a ação passa a ser diversa (art. 301, §2 , do CPC, a contrario sensu) ${ }^{, 30}$.

Nesse sentido, CHIOVENDA lembra que o princípio da economia processual está a recomendar sua utilização o máximo possível, favorecendo a mudança da demanda. $\mathrm{O}$ autor lembra que os legisladores austríaco e alemão foram levados a "sacrificar os rigorosos princípios da identificação das ações, admitindo que possa mudar-se a demanda quando o magistrado julga que a defesa do réu não seja substancialmente agravada"31. Porém, o sistema brasileiro não agasalha essa possibilidade, dispondo que, uma vez estabilizada a demanda, não é permitido inovar no processo, nem para acrescentar, nem para substituir pedidos (arts. 294 e 264, do CPC).

\section{I.2.3. Causa de pedir}

De forma geral, identifica-se a causa petendi respondendo-se à pergunta: "Perchè litigamo?"32. Porém, do ponto de vista acadêmico-científico, a questão coloca-se de forma muito mais ampla.

Dos três elementos da demanda, a causa de pedir apresenta-se como a mais complexa e controvertida. Os autores discordam quanto à profundidade do seu conteúdo e quanto aos elementos mínimos que a compõem. A falta de um denominador comum entre os doutrinadores reflete-se, na prática, em uma grande dificuldade de saber-se quando duas ações são ou não iguais, tendo-se em vista a identidade da causa petend $i^{33}$.

\footnotetext{
30 BARBOSA MOREIRA, José Carlos. O novo processo civil brasileiro: exposição sistemática do procedimento. Rio de Janeiro: Forense, 1999, p. 13.

${ }^{31}$ CHIOVENDA, Giuseppe. Instituições..., op. cit., , v. I, p. 364.

32 CALAMANDREI, Piero. Instituzioni di diritto processuale civile secondo Il nuovo codice. Padova: Cedam, 1943, v. I, p. 139. No mesmo sentido, BARBOSA MOREIRA, José Carlos. Ibidem, p. 15.

${ }^{33}$ ARRUDA ALVIM. Ensaio..., op. cit., v. II, p. 76.
} 
CANOVA destaca que o estudo de causa de pedir e da identificação do conteúdo da demanda civil é marcado por uma dificuldade de sistematizar idéias e estabelecer um posicionamento uniforme, em face da multiplicidade de inferências e momentos processuais em que o tema revela-se imperativo ${ }^{34}$. Um dos principais pontos acerca do qual doutrinadores divergem diz respeito ao conteúdo da causa de pedir (teoria da individuação $x$ teoria da substanciação). Mas, antes de enfrentar tal questão, importa analisar se a causa petendi integra ou não o objeto litigioso do processo.

\section{I.2.3.1. Objeto do processo (Streitgegenstand)}

Como visto, grande parte da doutrina entende que o objeto litigioso do processo "é a pretensão a determinado bem da vida, quando apresentada ao Estado-juiz em busca de

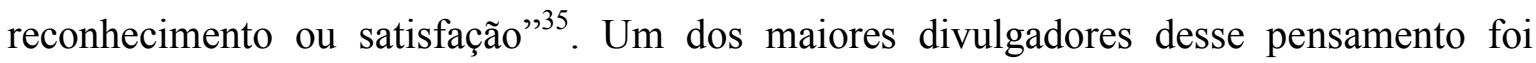
SCHWAB, para quem o objeto litigioso define-se apenas e tão-somente pelo pedido (Antrag), sem o concurso de qualquer fundamento ou fato constitutivo (Lebensvorgang) / causa petendi (Sachverhalt), salvo para a delimitação da coisa julgada ${ }^{36}$.

Em que pesem os inúmeros estudos produzidos nessa linha, outros tantos autores entendem que o objeto do processo abrange, também, a causa de pedir, especialmente porque o pedido, por si só, não é suficiente para resolver questões como estabilização, alteração ou acúmulo de demanda, litispendência e coisa julgada. Com efeito, a mera pretensão do demandante não permite a exata identificação da demanda, sendo necessário investigar, do ponto de vista objetivo, os fundamentos que delimitam ou contornam o pedido.

${ }^{34}$ CANOVA, Augusto Cerino. La domanda giudiziale ed il suo contenuto. Comentario del Codice di Procedura Civile. Torino: Uted, 1980, p. 10. Apud LEONEL, Ricardo de Barros. A causa petendi nas ações coletivas. In Causa de pedir e pedido no processo civil. CRUZ E TUCCI, José Rogério e BEDAQUE, José Roberto dos Santos (Coords.). São Paulo: Revista dos Tribunais, 2002, p. 126.

${ }^{35}$ DINAMARCO, Cândido Rangel. Instituições..., op. cit., p. 180 (g.n.).

${ }^{36}$ SCHAWB, Karl Heinz. El objeto litigioso en el processo civil. BANZHAF, Tomas (Trad.). Buenos Aires: Ediciones Jurídicas Euopa-America, 1968. No mesmo sentido LIEBMAN: "o pedido do autor é o objeto do processo" (LIEBMAN, Enrico Tullio. Estudos sobre o Processo Civil brasileiro. São Paulo: Bushatsky, 1976, p. 132). 
Opondo-se a SCHWAB, HABSCHEID decompôs o objeto litigioso em dois elementos: as pretensões do autor e o estado de fato em que se funda a pretensão. A razão para se conjugarem ambos os elementos objetivos da demanda na conformação do objeto litigioso do processo residiria no fato de que a causa de pedir representa na demanda elemento indissociável do pedido, sendo impossível o entendimento deste sem a ocorrência daquela. De fato, somente com a análise de ambos os elementos pode-se depreender o objeto do processo, principalmente para fins de identificação de demandas.

A doutrina de HABSCHEID encontrou eco na Itália, tendo GIANOZZI defendido que integram o objeto litigioso o petitum e a causa petendi, esta última integrada pelo fato constitutivo do direito controvertido. Por seu turno, FAZZALARI ${ }^{37}$ propugnou que a causa de pedir introduz o direito subjetivo (substancial) no processo. É a partir dessa alegação que se tem o parâmetro para definir a jurisdição, a competência, a legitimação para agir etc.. Sintetizando o pensamento do autor italiano, TUCCI ressalta que a causa petendi “corresponde, em última análise, ao elo de ligação entre a norma de direito material supostamente violada e o juízo, a partir do momento em que a situação substancial, retratada na petição inicial, é levada à cognição judicial"38.

Prosseguindo nesse raciocínio, pode-se dizer que a mesma dificuldade existente para cindir completamente a pretensão processual da pretensão material existe também para "separar em dois campos opostos o pedido e a causa de pedir, dada a relação de instrumentalidade que existe entre os mesmos, na definição do objeto do processo" ${ }^{\text {„3 }}$. Nas palavras de MESQUITA:

Causa petendi e petitum, intimamente ligados, qual verso e reverso da mesma medalha, ou alicerces e paredes de mesmo edifício, são por excelência os elementos identificadores do objeto do processo, pois o petitum é condição da existência da causa petendi e esta, por sua vez, não se limita a qualificá-lo ou restringi-lo, mas o individua plenamente ${ }^{40}$.

\footnotetext{
${ }^{37}$ FAZZALARI, Elio. Note in tema di diritto e processo. Milano: Giuffrè, 1957, p. 122.

${ }^{38}$ CRUZ E TUCCI, José Rogério. A causa petendi...,op. cit., p. 127.

39 GABBAY, Daniela. Processo coletivo e elementos objetivos da demanda. Dissertação (Mestrado). 23.10.2007. Orientador: Prof. Dr. Carlos Alberto de Salles. São Paulo, 2007. Faculdade de Direito, Universidade de São Paulo, p. 45, citando DINAMARCO. Capítulos de sentença. São Paulo: Malheiros, 2006, p. 48.

${ }^{40}$ MESQUITA, José Ignácio Botelho de. A causa petendi nas ações reivindicatórias. Teses, Estudos e Pareceres de Processo Civil. São Paulo: Revista dos Tribunais, 2005, p. 140.
} 
A bem ver, portanto, pode-se concluir que a inclusão dos fatos no objeto litigioso do processo é indispensável para a tarefa de identificar demandas, pois "no estudo do objeto litigioso encontramos o elemento material da litispendência»"41. Ao analisar a importância do fato na geração do direito, ARRUDA ALVIM exemplifica com uma questão possessória, em que 'A' demanda ' $B$ ' reivindicando sua posse e vence a demanda. Passados alguns anos, 'B' volta a invadir a área, dando ensejo à propositura de uma segunda ação, em que 'A' demanda 'B' reivindicando sua posse. Por tratar-se das mesmas partes ('A' $x$ 'B'), do mesmo objeto material (a área) e, aparentemente, da mesma causa de pedir (a posse), a segunda ação poderia, em tese, ser extinta por exceção de causa julgada, segundo a teoria das três identidades. Porém, se atentarmos para o fato que originou a segunda ação, ver-se-á que se trata de fato novo e, portanto, de nova causa petendi, não se lhe aplicando a exceção da coisa julgada. "Com isto se constata que o fato é elemento integrativo do direito e, pois, de sua própria identificação" ${ }^{, 42}$.

De qualquer forma, ainda que não se considere a causa de pedir como integrante do objeto do processo, é preciso reconhecer que a pretensão do demandante "não pode ser corretamente compreendida e delimitada sem a visualização daqueles, pois é por meio de tais fundamentos que os limites do objeto litigioso são precisamente definidos" ${ }^{\text {"43 }}$. Daí se dizer que, no mínimo, o objeto litigioso do processo deva ser entendido como pretensão processual iluminada pela sua motivação, consistente na causa de pedir (= thema decidendum $)^{44}$.

Para o fim de resolverem-se questões como identificação, estabilização, alteração ou acúmulo de demandas, não há dúvida de que a eadem causa petendi deva ser considerada. Isso porque, como visto acima, a diversidade de causa petendi implica ação diversa $^{45}$. Pois bem. Partindo da premissa de que a causa de pedir integra o objeto litigioso do processo, resta, ainda, analisar seu conteúdo, à luz das teorias da substanciação e da individuação.

\footnotetext{
${ }^{41}$ ARRUDA ALVIM. Ensaio..., op. cit., v. II, p. 58.

${ }^{42}$ Idem, ibidem, v. II, p. 61/62.

${ }^{43}$ LEONEL, Ricardo de Barros. Causa de pedir e pedido: o direito superveniente. São Paulo: Método, 2006, p. 103, passim.

${ }^{44}$ Idem, ibidem, p. 86.

${ }^{45}$ Nesse sentido, ARRUDA ALVIM salienta que "a diversidade de causa petendi inviabiliza a litispendência, como pressuposto processual negativo" (Ibidem, p. 76).
} 


\section{I.2.3.2. O que compõe a causa petendi?}

Admitindo-se, portanto, que a causa de pedir integra o objeto do processo, cumpre analisar quais elementos da causa de pedir estariam inclusos nesse conceito. Em linhas gerais, o conceito de causa petendi resulta da conjugação de três elementos:

a) A afirmação da existência de uma relação jurídica (propriedade, compra e venda, mútuo, locação, mandato e semelhantes); $b$ ) A afirmação da existência do fato particular que, no âmbito daquela relação jurídica, dá origem ao direito particular invocado [ex. vencimento da prestação] $(\ldots)$; c) A afirmação da existência do fato de que decorre o interesse de agir (inadimplemento, fato determinante da incerteza na ação declaratória) $)^{46}$.

Didática e resumidamente, tais elementos são conhecidos como causa de pedir remota, assim entendido o fato constitutivo do qual se originou a relação jurídica substancial entre autor e réu; e causa de pedir próxima, isto é, a repercussão jurídica desses fatos, o efeito que o ordenamento jurídico lhes atribui ${ }^{47}$.

A respeito da inclusão de ambos ou de apenas um desses elementos no conceito de causa de pedir - e, por conseguinte, no objeto do processo -, duas correntes se opõem: a teoria da substanciação e a teoria da individuação.

Em apertada síntese, pode-se dizer que, de acordo com a teoria da individuação, basta que o autor esclareça o direito ou a relação jurídica afirmada, ao passo que, para a teoria da substanciação, é necessário descrever os fatos constitutivos do direito alegado para identificar-se uma demanda ${ }^{48}$.

\footnotetext{
${ }^{46}$ CHIOVENDA, Giuseppe. Instituições..., op. cit., v. I, p. 359 (g.n.).

${ }^{47}$ Não há que se confundir fundamento jurídico com fundamento legal, este totalmente dispensável por força do princípio iuria novit curia.

48 Exemplificando: pela teoria da individualização, bastaria conhecer a relação jurídica (direito de propriedade - causa próxima), ao passo que, pela teoria da substanciação, seria necessário conhecer o modo de aquisição da propriedade (causa remota).
} 


\section{I.2.3.2.1. Teoria da substanciação}

A teoria da substanciação dispõe que uma ação se individualiza por meio dos elementos de fato que tornaram concreta a vontade da lei. Segundo essa teoria, os fatos constitutivos são imperativos para identificar a ação; ou, em outras palavras, os acontecimentos da vida em virtude dos quais nasce o interesse ou a necessidade de agir são decisivos para estabelecer-se o conteúdo da causa petendi.

Logicamente, nem todo fato deduzido no processo tem importância para a determinação da causa. Os fatos que constituem a causa de pedir (e, por conseguinte, o objeto do processo) são somente os fatos jurídicos, isto é, aqueles fatos carregados de efeito pelo ordenamento jurídico, que "podem ter influência na formação da vontade concreta da lei" $" 49$.

A esse respeito, TUCCI salienta que, para a teoria da substanciação, a causa de pedir, inclusive no que tange aos direito absolutos, "corresponde ao fato gerador do direito. Afloram diferentes as demandas sempre que diversificado for o fato constitutivo invocado (diverso como acontecimento concreto) ${ }^{\natural 50}$.

Segundo a teoria da substanciação, a descrição do fato, em concreto, tem importância para identificar a demanda, pois não basta apenas indicar o direito e sua natureza (de propriedade, de crédito etc.); “é necessário revelar o fato pelo qual o direito afeta uma determinada pessoa, e não o fato em abstrato (depósito, compra e venda etc.), mas em concreto (tal depósito, tal compra e venda etc.) ${ }^{\natural 51}$.

\footnotetext{
${ }^{49}$ A esse respeito, destaque-se a lição de CHIOVENDA: "Denominam-se fatos jurídicos aqueles de que se deriva a existência, a modificação ou a cessação de uma vontade concreta de lei: como tais, distinguem-se dos fatos simples ou motivos, que só têm importância para o direito enquanto possam servir a provar a existência de um fato jurídico. Temos, pois, diversas categorias de fatos jurídicos, cuja exata determinação é de suma relevância para o processo (em particular para a doutrina das exceções, dos poderes do juiz, do ônus da prova)". (In Instituições..., op. cit., v. I, p. 7, 358 e 359).

${ }^{50}$ CRUZ E TUCCI, José Rogério. $A$ causa petendi..., op. cit., p. 121 (g.n.).

${ }^{51}$ ZANZUCCHI, Marco Túlio. Nuove demande, nuove prove in appello. Milão, Giuffrè, 1916, p. 336.
} 
Na mesma linha, ARRUDA ALVIM pondera que "os fatos jurídicos (...) que constituem o complexo da causa petendi, integram uma dada ação, para a finalidade de identificá-la" ${ }^{, 52}$. Na visão do autor, é impossível, na tarefa de identificação de demandas, desvincular totalmente o fato do direito; até porque os acontecimentos da vida (fatos) só têm relevância ou significância jurídica se alguma norma assim o reconhecer (no sentido de que a norma qualifica ofato). Diante disso, conclui:

É nesse sentido que se deve entender a junção, a verdadeira simbiose existente entre fato e direito. $\mathrm{O}$ fato ou os fatos representativos da causa petendi têm que ser indicados para que o juiz possa bem compreender dentro do ordenamento jurídico, qual a categoria jurídica a respeito da qual se discute e, em função da qual se pretendam tais ou quais conseqüências $^{53}$.

Isso tudo demonstra que os fatos fazem parte do objeto litigioso. Tanto que, se forem mudados os fatos, a relação jurídica deduzida poderá ser inevitavelmente alterada. Isso indica que a relação jurídica é qualificada em função dos fatos sobre os quais ela se $\operatorname{assenta}^{54}$. Daí se dizer que, mudados os fatos jurídicos, altera-se o objeto litigioso, com reflexos diretos em questões como estabilização, alteração ou acúmulo de demanda, litispendência e coisa julgada. Na lição de CHIOVENDA, “l'azione s'individua per il fatto e non per la norma di legge,

\section{I.2.3.2.2. Teoria da individuação}

Grosso modo, pela teoria da individuação, entende-se que a indicação da relação jurídica que se pretende fazer valer jurisdicionalmente é suficiente para identificar a demanda como fundamento do pedido. No lugar dos fatos, assume relevância a individuação da relação jurídica invocada, que deve ser diferenciada das demais.

\footnotetext{
${ }^{52}$ ARRUDA ALVIM. Ensaio..., op. cit., v. II, p. 80.

${ }^{53}$ Idem, ibidem, p. 81 (g.n.).

${ }^{54}$ Cf. Idem, ibidem, p. 81 (g.n.).

${ }^{55}$ Apud ARRUDA ALVIM. Ibidem, p. 142 (nota 33).
} 
Pela teoria da individuação, o que importa é apenas o fundamento jurídico, a relação constitutiva do direito, que traça o perfil jurídico dos fatos constantes da demanda e dá apoio ao pedido; vale dizer, a "relação jurídica que será submetida a exame e em função da qual pleiteiam-se conseqüências jurídicas" "56. Nesse contexto, a alegação dos fatos pode até ser usada, mas não é imprescindível, pois os fatos jurídicos servem apenas para a prova do direito alegado, mas não para a identificação da demanda ${ }^{57}$. Com efeito, identifica-se a demanda pelo conteúdo do direito deduzido, ficando absorvidos todos os fatos que servem à sustentação do direito invocado em juízo. Destarte, inviabiliza-se que, em ulterior ação, seja formulada a mesma pretensão, com amparo em fatos já existentes na época da primeira ação, ainda que não alegados ${ }^{58}$.

Exemplo clássico da aplicação da teoria da individuação diz respeito a ações envolvendo direitos reais. Para o fim de identificarem-se tais demandas, bastaria conhecer a relação jurídica, como, por exemplo, o direito de propriedade, sendo dispensável conhecer o modo de aquisição da propriedade. Isso se justifica pela premissa segundo a qual, nessas ações, "a identificação da res in iudicio deducta pelo conteúdo do direito deduzido leva em consideração, de forma prática, não a espécie de direito, mas a impossibilidade de repetição, simultânea, da mesma situação de direito material, entre as mesmas partes"

\section{I.2.3.2.3. Importância do tema: estabilização da demanda}

A adoção de uma ou de outra corrente gera conseqüências distintas quanto à possibilidade de alteração da demanda e, em última análise, atinge os institutos da litispendência e da coisa julgada. Isso porque, admitindo-se que apenas o fundamento jurídico integra o objeto do processo, entende-se que somente a alteração do direito alegado induziria à modificação da demanda. Por via de conseqüência, seria "livre" a alteração dos fatos, sem que isso implicasse demanda diversa.

\footnotetext{
${ }^{56}$ ARRUDA ALVIM. Ensaio..., op. cit., v. II, p. 80.

${ }^{57}$ LEONEL, Ricardo de Barros. Causa de pedir..., op. cit., p. 88.

${ }^{58}$ Idem, ibidem, p. 88/89.

${ }^{59}$ Idem, ibidem, p. 98.
} 
É natural, pois, que a adoção da teoria da individuação acarrete demora na solução da demanda; mas, em contrapartida, aumenta-se a possibilidade de eliminação definitiva do conflito, aproximando-se de um dos escopos do processo: a pacificação social. Até porque, como é sabido, o processo "alimenta-se das crises jurídicas preexistentes e, quando termina, apresenta um resultado consistente na sua eliminação"

Por outro lado, adotando-se a teoria da substanciação, conclui-se que, mudados os fatos jurídicos, altera-se o objeto litigioso, tratando-se de demanda diversa. Com isso, fica obstada a alteração dos fatos após a estabilização da demanda (art. 264, CPC), de forma que fatos novos - leia-se: não trazidos ao processo - só podem ser deduzidos em nova demanda. Por conseguinte, a coisa julgada só abrange os pontos de direito material que tenham sido decididos pelo juiz, não abrangendo outras questões que, embora relacionadas com a mesma pretensão, não tenham sido trazidas ao processo ${ }^{61}$.

Não obstante seja vedado ao autor "incluir" nova causa remota na mesma demanda, nada impede de fazê-lo em processo autônomo ${ }^{62}$, tratando-se, em tese, de ações distintas, por diversidade da causa de pedir (erro $x$ dolo). Nesse caso, não se tratará de litispendência, mas sim de conexão e o juiz poderá reunir os feitos para julgamento conjunto.

Ao impedir a alteração dos fatos após a estabilização da demanda, a teoria da substanciação acarreta, de certa forma, uma aceleração no procedimento, sem, contudo, encerrar definitivamente a crise de direito material, dando margem à propositura de ulterior demanda a respeito do mesmo problema concreto. Talvez por isso, no direito brasileiro, vigore o princípio da eventualidade, segundo o qual autor e réu devem alegar, em um mesmo momento, todos os meios de ataque e defesa, o que, nos parece, não deixa de ser uma homenagem à teoria da individuação.

\footnotetext{
${ }^{60}$ DINAMARCO, Cândido Rangel. Instituições..., op. cit., p. 181.

${ }^{61}$ ARRUDA ALVIM. Ensaio..., op. cit., v. II, p. 84.

${ }^{6}$ Nesse sentido, o artigo 157 do Código de Processo Civil de 1939 dizia que: "quando o autor houver omitido, na petição inicial, pedido que lhe era lícito fazer, só em ação distinta poderá formulá-lo”.
} 
Apesar da adoção da teoria da substanciação (art. 282, III, do CPC), a regra da eventualidade impõe um sistema rígido de preclusões, a tal ponto que, "passada em julgado uma sentença de mérito, reputar-se-ão deduzidas e repelidas todas as alegações e defesas, que a parte poderia opor assim ao acolhimento como à rejeição do pedido" (art. 474, CPC).

Nesse sentido, sem abrir mão dos fatos constitutivos no objeto litigioso, pode ser preferível flexibilizar e permitir a modificação da demanda, com vistas a eliminar a crise de direito, em vez de aplicar extremo rigor na estabilização da demanda e provocar uma nova ação - conforme se verá, mais detidamente, no Capítulo IV, infra.

Como conclusão do presente subitem, merece destaque a lição de CHIOVENDA, que, ao tratar dos elementos objetivos da demanda, pedido e causa de pedir, asseverou: "são esses dois últimos elementos que, em verdade, se referem à identificação do bem da vida de que se trata nas ações que são objeto de confronto: o outro elemento [subjetivo pessoas] tem em vista a pertinência ativa ou passiva desse bem" ${ }^{\prime 63}$.

\section{I.2.3.2.4. Proposta de aproximação ${ }^{64}$}

Como ocorre em inúmeros outros casos de dissonância acadêmica (corrente ' $A$ ' $x$ corrente 'B'), aqui também se propõe uma aproximação entre as teorias da individuação e da substanciação. O fundamento para tal aproximação estaria no próprio artigo 282, inciso III, do CPC, que exige que o autor especifique, na petição inicial, não só os fatos, como também os fundamentos jurídicos do pedido. Afinal, "há uma relação de causa e efeito entre a relação jurídica e o fato de que ela emerge" ${ }^{, 65}$.

Enquanto muitos autores partem do pressuposto de que nosso legislador teria adotado, apenas e tão somente, a teoria da substanciação, outros entendem que o Código de Processo Civil incluiu algo da teoria da individuação, obtemperando aquela corrente. Nessa linha, destaca-se a lição de CRUZ E TUCCI, bem sentida por LEONEL:

\footnotetext{
${ }^{63}$ CHIOVENDA, Giuseppe. Instituições..., op. cit., v. I, p. 355 (g.n.).

${ }^{64}$ Este tema será analisado, novamente, no Capítulo III, infra.

${ }^{65}$ ARRUDA ALVIM. Ensaio..., op. cit., v. II, p. 61/62.
} 
"não se trata de opção por uma ou outra teoria (...). Trata-se sim da espécie de bem jurídico tutelado na demanda, a indicar a necessidade de maior ou menor detalhamento na descrição da causa de pedir" ${ }^{\prime 66}$.

A proposta de ambos os autores é atrelar o nível de detalhamento dos fatos à modalidade de direito material deduzido, in status assertionis - direitos reais $x$ direitos obrigacionais. Resgatando alguns conceitos e prosseguindo no raciocínio, LEONEL assevera que:

A identificação da demanda deve ser realizada por meio da observação do direito material afirmado pelo autor (in status assertionis), que se traduz, em outros termos, pela pretensão processual, ou pedido devidamente iluminado pela causa de pedir. E, para a especificação do direito substancial feito valer, terá maior relevância ou o fato constitutivo, ou então o próprio conteúdo do direito: tudo a depender da possibilidade, ou não, de coexistência de mais de uma situação jurídica similar, contemporaneamente, entre as mesmas partes ${ }^{67}$.

\section{I.3. Teoria da identidade da relação jurídica}

Como visto, a teoria da tríplice identidade foi positivada pelo CPC, em seu artigo $301, \S 2^{\circ}$, segundo o qual a modificação de qualquer dos elementos diferencia uma demanda da outra. Ocorre, porém, que nem sempre a mudança deste ou daquele elemento constitutivo da ação, isoladamente considerado, pode causar a mudança da ação mesma, pois, como ensina PARÁ FILHO, "no exame do problema, não há como desprezar a identidade da relação jurídica substancial" ${ }^{\prime 68}$.

\footnotetext{
${ }^{66}$ CRUZ E TUCCI, José Rogério. A causa petendi..., op. cit., p. 256. Apud LEONEL, Ricardo de Barros. Causa de pedir..., op. cit., p. 82 (g.n.).

${ }^{67}$ LEONEL, Ricardo de Barros. Causa de pedir..., op. cit., p. 98.

${ }^{68}$ PARÁ FILHO, Tomás Francisco de Madureira. Estudo sobre a conexão de causas no processo civil. São Paulo: Revista dos Tribunais, 1964. Apud CRUZ E TUCCI, José Rogério. Ibidem, p. 212.
} 
É bem verdade que:

Perante várias situações concretas, a teoria da tríplice identidade desponta insuficiente para desempenhar o papel que lhe é reservado no confronto de duas ou mais ações. E, a despeito de sua adoção expressa pelo nosso Código, não pode restar dúvida de que a doutrina e a jurisprudência devem procurar soluções para determinadas questões que extravasam os lindes daquela ${ }^{69}$.

Essa constatação autoriza a conclusão de CRUZ E TUCCI no sentido de que:

Diante de tais situações excepcionais, que revelam a insuficiência da teoria dos tria eadem, duas regras devem ser observadas: a) não constitui ela um critério absoluto, mas, sim, uma 'boa hipótese de trabalho', até porque ninguém se arriscou a apontar outra que a superasse; e $b$ ) quando for inaplicável, perante uma situação concreta, deve ser relegada a segundo plano, empregando-se, em seu lugar, a teoria da identidade da relação jurídica ${ }^{70}$.

Com efeito, se os fatos das duas demandas deixarem margem à dúvida, quanto à respectiva identificação, ARRUDA ALVIM propõe que o intérprete se aprofunde no "exame da relação jurídica deduzida em juízo e, entendendo que são idênticas (a da primeira e da segunda ação), como também as conseqüências jurídicas pedidas, deverá obstar a segunda demanda" ${ }^{, 71}$.

A aplicação de uma e não de outra teoria pode trazer resultados surpreendentes na relação entre demandas, como, por exemplo, no caso de duas ações relacionadas ao mesmo contrato de locação, uma revisional de aluguel e outra renovatória. Nesse caso, a conexão entre as ações poderia ser reconhecida "não pela identidade de fundamentos, mas pela afinidade concernente à relação jurídica material", 72 .

${ }^{69}$ CRUZ E TUCCI, José Rogério. A causa petendi..., op. cit., p. 213.

${ }^{70}$ Idem, ibidem, p. 213.

${ }^{71}$ ARRUDA ALVIM. Ensaio..., op. cit., v. II, p. 103 (g.n.).

${ }^{72}$ CRUZ E TUCCI, José Rogério. Ibidem. , p. 215. 
SAVIGNY foi um dos precursores dessa teoria, segundo a qual a identificação das ações depende, exclusivamente, da identidade da questão jurídica ("identität der Rechtsfrage"). Outro expoente dessa corrente foi COGLIOLO, para quem "o ponto central do problema consiste em saber quando dois direitos são iguais e, para se conseguir a resposta a essa questão, necessário se faz saber, em primeiro lugar, o que 'è il rapporto giuridico in sè'”. A partir disso, o autor propõe substituir a teoria das três identidades, com base no seguinte raciocínio: "due diritti sono identici quando contengono lo stesso repporto giuridico nascente dallo stesso fatto" ${ }^{73}$.

A teoria não está tão longe do nosso direito positivo, como se observa nas disposições do CPC relacionadas ao litisconsórcio. Enquanto o inciso I do artigo 46 (comunhão de direitos ou obrigações relativamente à lide) adota o critério da identidade da relação jurídica, os demais incisos adotam o tria eadem. Isso porque o critério do inciso I está fundado no direito alemão e significa "co-titularidade da relação jurídico-material ativa (direito) ou passiva (obrigação) posta no processo como seu objeto principal”"74.

A esta altura, vale abrir um parêntese para salientar que substanciação tem íntima relação com a teoria da tríplice identidade, ao passo que a individuação guarda estreita relação com a teoria da identidade da relação jurídica, sendo aquela primeira "dupla" a mais aceita doutrinária e legislativamente.

Para ARRUDA ALVIM - com quem concordamos -, uma teoria não exclui a outra; ao contrário, se complementam, pois, como visto, ambas destinam-se a uma única finalidade: dizer quando o conteúdo de um processo é idêntico ao de outro ${ }^{75}$. Assim, o primeiro passo para identificar as ações seria a individuação da relação jurídica e do fato de que ela decorre. Em seguida, o critério dos três elementos pode auxiliar nessa tarefa, consistindo em um "verdadeiro meio, cujo fim é, realmente, o da identificação de uma relação jurídica litigiosa" ${ }^{, 76}$.

\footnotetext{
${ }^{73}$ COGLIOLO, Pietro. Trattato teorico e pratico della eccezione di cosa giudicata, secondo il diritto romano e il codice civile italiano, con accenni al diritto intermedio, dell'avv. Fratelli Bocca, 1883, p. 209 e 212. Apud ARRUDA ALVIM. Ensaio..., op. cit., v. II, p. 61.

${ }^{74}$ DINAMARCO, Cândido Rangel. Litisconsórcio. São Paulo: Malheiros, 1994, p. 85.

${ }^{75}$ ARRUDA ALVIM. Ensaio..., op. cit., v. II, p. 62.

${ }^{76}$ Idem, ibidem, p. 63.
} 
Ao discutir o que vêm a ser ações idênticas, o citado autor salienta que:

O problema pode não se apresentar e, comumente não se apresenta, com essa clareza meridiana. Normalmente o que ocorre é que as demandas apresentam-se, por assim dizer, tentando camuflar a identidade jurídica existente ente elas, justamente no intuito de tentar-se evitar a 'exceção' de litispendência oponível na segunda demanda, com o objetivo final de alcançar-se nesta, e não na primeira, a coisa julgada ${ }^{77}$.

Não se pode desconsiderar a hipótese de o próprio autor, intencionalmente, invocar fatos diversos na segunda demanda, objetivando, porém, o mesmo resultado jurídico pedido na primeira. "Neste caso, é de se convir, ter inteiro cabimento a exceção de litispendência" ${ }^{\text {78 }}$, por força da teoria da individualização da relação jurídica.

Para concluir essa breve explanação acerca da teoria da identidade da relação jurídica (a qual será retomada no Capítulo III, infra), pede-se vênia para transcrever os três tópicos desenvolvidos por LEONEL:

1) A idéia dos três elementos das ações, com sua concepção histórica, especialmente, e com maior importância e relevo a causa petendi serve efetivamente como ponto de partida para a identificação e individualização das demandas, mas não é necessariamente o único e exclusivo critério adotado no sistema processual brasileiro para este fim; 2) Em diversos momentos, no estudo de distintos institutos processuais, chega-se à conclusão de que a teoria dos tria eadem é insuficiente para o equacionamento de todos os dilemas vertentes do sistema, sendo, destarte, necessária a adoção de critérios subsidiários que sirvam ao mesmo fim, ou seja, a identificação das ações e solução de fenômenos processuais correlatos a esta questão, entre os quais podemos citar a litispendência, a coisa julgada, o litisconsórcio, a conexão e a continência;

3) A constatação de que a teoria dos três elementos de identificação é insuficiente, embora figure como hipótese razoável de trabalho, se manifesta inicialmente no processo civil tradicional, de cunho individual,

${ }^{77}$ ARRUDA ALVIM. Ensaio..., op. cit., v. II, p. 102.

${ }^{78}$ Idem, ibidem. 
mas ganha maior relevo e evidência, referida observação, quando se estuda o processo coletivo. Neste, pelas peculiaridades inerentes à natureza dos direitos tutelados (difusos, coletivos e individuais homogêneos), surge espaço ainda maior de verificação da necessidade de critérios subsidiários ao difícil mister relacionado à individualização da demanda e à solução de problemas verificados em fenômenos processuais correlatos $^{79}$.

\section{I.4. Identidade total e parcial de ações}

Ainda dentro deste primeiro Capítulo, cumpre recordar os conceitos e as conseqüências jurídicas, no processo civil clássico, dos principais fenômenos relacionados à identidade de ações, a saber: litispendência, coisa julgada, conexão e continência.

De início, importa salientar que há diferentes graus de afinidade entre duas ações. Valendo-se de uma comparação entre duas pessoas, CHIOVENDA dizia que elas podem até ter diferentes graus de afinidade, mas “quanto a ser ou não o mesmo indivíduo, não há graduação possível" ${ }^{\prime 80}$. Os institutos processuais clássicos que tratam da identidade absoluta são a litispendência e a coisa julgada, ambos pressupostos processuais negativos, enquanto a conexão e a continência tratam da identidade parcial de ações, que comporta diferentes graus de aproximação entre elas.

A razão das exceções de litispendência e coisa julgada é a mesma: evitar inútil duplicação de atividade pública. Porém, enquanto a litispendência formula-se perante uma demanda em curso, a coisa julgada supõe um julgado, isto é, um pronunciamento definitivo e, pois, "funda-se preponderantemente no motivo de que o Estado não deve permitir que um bem, já por ele reconhecido, sofra diminuição ou prejuízo por uma nova decisão sua" ${ }^{\sharp 1}$ (= exceptio rei iudicatae). Com efeito, o que é primordial para ambos os institutos é

\footnotetext{
${ }^{79}$ LEONEL, Ricardo de Barros. A causa petendi nas ações coletivas. In Causa de pedir e pedido no processo civil. CRUZ E TUCCI, José Rogério e BEDAQUE, José Roberto dos Santos (Coords.). São Paulo: Revista dos Tribunais, 2002, p. 186.

${ }^{80}$ CHIOVENDA, Giuseppe. Instituições..., op. cit., v. I, p. 355.

${ }^{81}$ Idem, ibidem, v.II, p. 386/388 (g.n.).
} 
não possibilitar pronunciamentos contraditórios sobre um mesmo bem jurídico ou uma mesma situação da vida ${ }^{82}$.

As hipóteses de ocorrência da exceção de litispendência e coisa julgada estão delineadas no artigo $301, \S \S 1^{\circ}, 2^{\circ}$ e $3^{\circ}$, do CPC, in verbis:

$\S 1^{\circ}$. Verifica-se a litispendência ou a coisa julgada, quando se reproduz ação anteriormente ajuizada.

$\S 2^{\circ}$. Uma ação é idêntica à outra quando tem as mesmas partes, a mesma causa de pedir e o mesmo pedido.

$\S 3^{\circ}$. Há litispendência, quando se repete ação, que está em curso; há coisa julgada, quando se repete ação que já foi decidida por sentença, de que não caiba recurso.

\section{I.4.1. Litispendência}

$\mathrm{Na}$ preciosa lição de FREDERICO MARQUES, litispendência é o fenômeno resultante da apresentação de uma lide. "Com a propositura da ação, o litígio adquire tonalidade processual e, em torno da área demarcada pelo pedido do autor, forma-se a litispendência" ${ }^{\sharp 3}$. Ou seja, como o próprio nome diz, litispendência significa apenas a pendência de uma lide.

ARRUDA ALVIM, que estudou profundamente o tema, analisa as diferentes facetas da litispendência, com destaque para seus efeitos de direito material e seus efeitos processuais. A primeira faceta revela a influência da litispendência sobre aspectos do direito material, com os seguintes efeitos: tornar a coisa litigiosa, constituir o devedor em mora e interromper a prescrição (o que se dá com a citação válida - art. 219, CPC). A segunda faceta diz respeito aos seus efeitos processuais, quais sejam, a prevenção do juízo

${ }^{82}$ Cf. ARRUDA ALVIM. Ensaio..., op. cit., v. II, p. 99.

${ }^{83}$ FREDERICO MARQUES, José. Instituições de direito processual civil. Rio de Janeiro: Forense, 1962, vol. III, p. 196. Acerca do tema, POTHIER assim se expressou: "Lorsqu'il y a um procès pendant entre les mêmes personnes, pour la même chose, et pour la même cause, dans une autre jurisdiction que celle où le defendeur est assignè, le defendeur peut demander son renvoi dans la jurisdiction où il y procès pour le même fait" (Traité de la Procédure Civile, p. 28. Apud ARRUDA ALVIM. Ibidem, p. 64). 
e "o próprio pressuposto processual negativo da litispendência, isto é, o estado assumido pelo processo mercê do qual se impede a reprodução da mesma causa, noutro processo" ${ }^{\text {" }}$.

Um dos efeitos negativos da litispendência, que comumente gera a confusão com o próprio fenômeno, é o de impedir o bis in idem, ou seja, impedir que haja um segundo processo para decidir as mesmas questões já sub judice ${ }^{85}$.

Considerando que a tutela jurisdicional deva ser proporcionada pelo Estado somente uma única vez, sendo vedada a existência, sobre a mesma causa, de mais de uma relação processual pendente, importa saber quando um "objeto litigioso (lide ou Streitgegenstand) é igual a outro, ou mais rigorosamente, é o mesmo, para, estabelecida essa identidade eliminar-se um dos processos, que correm simultaneamente" ${ }^{, 86}$.

Conforme se depreende dos artigos 267, V, e 301, V, do CPC, a propositura de uma demanda cria um obstáculo intransponível à repropositura e à constituição válida do novo processo, vedação esta que se justifica, em primeiro lugar, pelo princípio da economia processual, para evitar a duplicidade de esforços tendentes à obtenção do mesmo resultado ou à solução do mesmo conflito de interesses; além, é claro, de afastar-se a possibilidade de decisões conflitantes, que comprometeriam a credibilidade, o prestígio e a autoridade do Poder Judiciário e provocariam incertezas no meio social ${ }^{87}$. Em suma, a exceção de litispendência evita, a um só tempo, a duplicação de esforços dos integrantes do processo e a contradição das decisões ${ }^{88}$.

\footnotetext{
${ }^{84}$ ARRUDA ALVIM. Ensaio..., op. cit., v. I, p. 235/237 (g.n.). A propósito, vale lembrar a definição de pressupostos processuais: "condições para obtenção de um pronunciamento qualquer, favorável ou desfavorável, sobre a demanda" (Cf. CHIOVENDA, Instituições..., op. cit., p. 110/111). A diferença principal em relação às condições de ação está no fato de que estas, se presentes, asseguram o direito a uma sentença de mérito, favorável ou desfavorável (Cf. LIEBMAN, Manuale..., op. cit., p. 58).

${ }^{85}$ Cf. DINAMARCO, Pedro Silva. Competência, conexão e prevenção nas ações coletivas. In Ação Civil Pública após 20 anos: efetividade e desafios. MILARÉ, Édis (Coord.). São Paulo: Revista dos Tribunais, 2005, p. 513.

${ }^{86}$ ARRUDA ALVIM. Ibidem, v. II, p. 57.

${ }^{87}$ Cf. MATTOS, Luiz Norton Baptista de. A litispendência e a coisa julgada nas ações coletivas segundo o Código de Defesa do Consumidor e os anteprojetos do Código Brasileiro de Processos Coletivos. In Direito Processual Coletivo e o Anteprojeto de Código Brasileiro de Processos Coletivos. GRINOVER, Ada Pellegrini, MENDES, Aluisio Gonçalves de Castro e WATANABE, Kazuo (Coords.). São Paulo: Revista dos Tribunais, 2007, p. 194/215, passim.

${ }^{88}$ CRUZ E TUCCI, José Rogério. $A$ causa petendi..., op. cit., p. 221.
} 


\title{
I.4.2. Coisa julgada
}

Por seu turno, a coisa julgada tem um espectro maior de atuação, a começar pelo fato de se constituir garantia constitucional, nos termos do artigo $5^{\circ}, \mathrm{XXXV}$, da CF.

Trata-se da qualidade de imutabilidade do comando da sentença, que, a exemplo dos institutos da decadência e da prescrição, tem como objetivo evitar a perduração de situações indefinidas na vida social, o que é indesejável, pois compromete nossa própria segurança $^{89}$. A coisa julgada configura, assim, impedimento à rediscussão da mesma ação, já julgada definitivamente, em processo autônomo.

Como qualidade da sentença, a coisa julgada pode ser formal ou material. A distinção entre ambas foi exposta por GIDI de maneira bastante didática: ambas são uma espécie de preclusão. A coisa julgada formal é uma preclusão "comum”, gerada pelo esgotamento das instâncias recursais, ao passo que a coisa julgada material é aquela que ocorre quando a lide (= mérito) é julgada ${ }^{90}$.

Quanto aos seus limites objetivos, a coisa julgada é delineada pelos artigos 468 , 469, 470 e 471 do CPC, de cuja conjugação extrai-se que:

\begin{abstract}
A coisa julgada material atinge o pedido formulado na petição inicial relativamente à causa de pedir lá indicada, o que forma a res in iudicium deducta, de sorte que é lícito ao Poder Judiciário decidir o mesmo pedido com base em causa de pedir não invocada na primeira demanda, pois não haverá a tripla identidade. Por outro lado, apenas a parte dispositiva da sentença está sujeita à coisa julgada material, o que não se passa com o pronunciamento do órgão jurisdicional sobre as questões prejudiciais na fundamentação da decisão ${ }^{91}$.
\end{abstract}

\footnotetext{
${ }^{89}$ GIDI, Antonio. Coisa julgada e litispendência em ações coletivas. São Paulo: Saraiva, 1995, p. 6, passim.

${ }^{90}$ Idem, ibidem, p. 10.

${ }^{91}$ MATTOS, Luiz Norton Baptista de. A litispendência..., op. cit., p. 200 (g.n.).
} 
Já no aspecto subjetivo, a coisa julgada vem disciplinada pelo artigo 472 do CPC, que acolheu o princípio do res inter alios iudicata aliis nec nocet nec prodest, ou seja, a sentença é lei (apenas) para as partes entre as quais é proferida. Vale salientar que a sentença, como ato de império do Estado, tem eficácia contra todos (eficácia natural da sentença); porém, a imutabilidade do comando da sentença (autoridade da coisa julgada) só se aplica às partes.

Mas além de ser um elemento estabilizador das relações jurídicas e imunizador da decisão, a coisa julgada também é fator de impedimento de nova decisão, para o que depende da confluência dos elementos identificadores da demanda (em especial, os elementos objetivos: pedido e causa de pedir) ${ }^{92}$. Tal qual ocorre na litispendência, o julgamento em definitivo de uma demanda cria um obstáculo intransponível à repropositura e à constituição válida do novo processo, nos termos dos artigos 267, V, e 301, VI, do CPC.

\section{I.4.3. Conexão}

Decorre do artigo 103 do CPC que duas ações são conexas "quando lhes for comum o objeto ou a causa de pedir”. A identidade ou a semelhança deve recair, pois, sobre os elementos objetivos das demandas.

Embora CHIOVENDA tenha dito que "a simples circunstância de haverem duas causas em comum o mesmo elemento subjetivo, ou, por outra, correrem entre as mesmas pessoas, não basta a fazerem-se considerar como conexas em sentido próprio" "93, BARBOSA MOREIRA, ao tratar do artigo 103 do CPC, explica que a teoria dos três elementos não recebeu, quando da edição do Código, "consagração na sua forma pura", de acordo com a qual seria necessária e suficiente, para configurar a conexão, a coincidência das causas em qualquer um dos elementos (pernonae, res, causa petendi). Aduz o autor

\footnotetext{
${ }^{92}$ Nesse sentido, GABBAY, Daniela. Processo coletivo..., op. cit., p. 45, citando DINAMARCO. Capitulos de sentença. São Paulo: Malheiros, 2006, p. 59.

${ }_{93}$ CHIOVENDA, Giuseppe. Instituições..., op. cit., v.II, p. 297.
} 
que "o Projeto e o Código passaram a contentar-se com a coincidência ou no objeto, ou na causa de pedir, silenciando quanto às partes" ${ }^{94}$.

MONIZ DE ARAGÃO, citado por CRUZ E TUCCI, afirma que para caracterizarse a conexão, é indiferente que os elementos 'comuns', exigidos pela lei, sejam, ou não, idênticos. Tanto poderá ocorrer identidade entre um, ou dois, deles, como poderá dar-se de serem 'comuns', isto é, semelhantes. "A comunhão ou semelhança, pode levar a identidade parcial. Assim é que são 'comuns' as 'ações' se em uma delas a causa petendi imediata for a mesma, embora seja diversa a causa petendi imediata" ${ }^{\text {95. }}$.

Uma vez constatada a ocorrência de conexão, o artigo 105 do CPC dispõe que "o juiz, de ofício ou a requerimento de qualquer das partes, pode ordenar a reunião de ações propostas em separado, a fim de que sejam decididas simultaneamente". Referido dispositivo segue a regra básica segundo a qual todas as causas que se poderiam propor unidas podem, a fortiori, unir-se, se propostas em separado ${ }^{96}$. A reunião das causas visa, em síntese, à decisão delas com uma única sentença (simultaneus processus), tendo em vista que "os nexos existentes entre elas aconselham solução harmônica, o que equivale a dizer contemporânea" 97 .

A reunião das demandas conexas para julgamento simultâneo justifica-se tanto pela economia processual que representa, quanto pelo efeito de evitar a prolação de decisões contraditórias, que pode gerar a ineficácia das decisões judiciais. Com efeito,

A possibilidade de que duas questões conexas venham a ser objeto de decisões distintas acarreta situação de extremo desconforto para o Poder Judiciário, ao expor um de seus maiores problemas, que é justamente o de controlar a existência de demandas conexas e a possibilidade de que venham a ser objeto de decisões que possam ocasionar conflitos ou contradições ${ }^{98}$.

\footnotetext{
${ }^{94}$ BARBOSA MOREIRA, José Carlos. A conexão de causas como pressuposto da reconvenção. São Paulo: Saraiva, 1979, p. 124.

${ }_{95}$ MONIZ DE ARAGÃO. Conexão e 'tríplice identidade'. Revista de Processo, 29 (1983):55. Apud TUCCI, José Rogério Cruz e. $A$ causa petendi..., op. cit., p. 214 (g.n.).

${ }^{96}$ CHIOVENDA, Giuseppe. Principii di diritto processualie civile. Nápoles: Jovene, 1928, p. 556.

${ }^{97}$ CHIOVENDA, Giuseppe. Instituições..., op. cit., v.II, p. 303.

${ }^{98}$ SILVA, Edward Carlyle. Conexão de causas. São Paulo: Revista dos Tribunais, 2006, p. 123.
} 
Quanto à obrigatoriedade da reunião para julgamento conjunto, a doutrina diverge, especialmente em razão da expressão "pode" empregada no artigo 105 do CPC. NERY \& NERY entendem que se trata de matéria de ordem pública, de forma que "o juiz é obrigado a determinar a reunião de ações conexas para julgamento, nada obstante esteja consignado na norma ora comentada que o juiz "pode ordenar", 99 . Para os autores, o comando emergente do CPC 105 é cogente, tanto que o artigo 253, I, do CPC, determina a distribuição por dependência quando os feitos se relacionarem por conexão ou continência.

No mesmo sentido, THEODORO JR. confirma ser de ordem pública o princípio que recomenda o julgamento comum das ações conexas, para impedir decisões contraditórias e evitar perda de tempo da Justiça e das partes com exame de questões em processos diferentes. Segundo o autor, "não pode, por isso, o juiz deixar de acolher o pedido de reunião de ações" 100 , advertindo que poderá haver "nulidade da sentença que julgar separadamente apenas uma das ações, se se verificar, de fato, o risco de julgamentos conflitantes" ${ }^{\prime 101}$.

A posição, contudo, não é unânime, como se verá mais adiante no Capítulo IV.

É preciso mencionar, ainda, os efeitos da conexão sobre a competência, pois, embora ela não constitua, em si, um critério de competência, ela se revela um critério de deslocamento da competência. De fato, quando as causas a serem unidas couberem a juízos distintos, o simultaneus processus influirá nas regras de competência, tendo em vista que, nesta hipótese, um dentre os diferentes juízes deverá julgar as causas unidas e, assim, passará a ter competência em causas para as quais não era (relativamente) competente. "Constitui-se, então, o fórum connexitatis materialis (fórum continentiae causarum ex identitate fundamenti agendi personali em caso de litisconsórcio)"102.

\footnotetext{
99 NERY JR., Nelson, NERY, Rosa Maria de Andrade. Código de Processo Civil Comentado. São Paulo: Revista dos Tribunais, 2003, nota $7^{\mathrm{a}}$ ao art. 105 do CPC.

100 THEODORO JR., Humberto. Curso de direito processual civil. São Paulo: Malheiros, 2002, p. 167.

${ }^{101}$ Idem, ibidem.

${ }^{102}$ CHIOVENDA, Giuseppe. Instituições..., op. cit., v.II, p. 303. No mesmo sentido, CRUZ E TUCCI salienta que "A causa de pedir assume papel fundamental para a fixação da competência ratione materiae. E, em inúmeras hipóteses, a conexão pela causa petendi é motivo suficiente para a prorrogação da competência tácita ou legal, ensejando que o juiz, em princípio relativamente incompetente, transforme-se em competente" (In A causa petendi..., op. cit., p. 220 - g.n.).
} 


\section{I.4.4. Continência}

Por fim, a continência veio tratada no CPC da seguinte forma: "Art. 104. Dá-se a continência entre duas ou mais ações sempre que há identidade quanto às partes e à causa de pedir, mas o objeto de uma, por ser mais amplo, abrange o das outras".

Embora a continência esteja estruturalmente relacionada à conexão, é certo que alguns autores a classificam como uma litispendência parcial ${ }^{103}$. Isso porque, diferentemente do art. 103, que se vale da expressão 'comum', o art. 104 utiliza-se da expressão 'identidade', mas limita-se aos elementos partes e causa de pedir, assumindo que, na continência, "essa identidade será tão-só parcial no que tange ao pedido, que em uma causa é mais amplo e por isso contém o outro (ou outros)" 104.

Por força do artigo 105 do CPC, a conseqüência prática decorrente da continência é a mesma da conexão, vista acima.

\footnotetext{
${ }^{103}$ Nesse sentido, AZEVEDO, Antonio Junqueira de. Conceito, identificação e conexão de causas no direito processual civil. São Paulo: Escolas Profissionais Salesianas, 1967.

${ }^{104}$ Nesse sentido, MONIZ DE ARAGÃO. Conexão..., op. cit., p 54.
} 


\section{CAPÍTULO II - ASPECTOS INTRÍNSECOS DA JURISDIÇÃO COLETIVA}

Analisados, de um lado, os institutos processuais clássicos voltados à solução dos problemas decorrentes da relação entre demandas intersubjetivas, cumpre abordar, de outro lado, os interesses metaindividuais: suas origens, suas características intrínsecas e, principalmente, seu tratamento processual diferenciado. $\mathrm{O}$ estudo das peculiaridades desses interesses mostra-se importante para que se possa, mais adiante, avaliar o cabimento do traslado daqueles institutos processuais analisados no Capítulo I para o plano da jurisdição coletiva e, eventualmente, justificar algumas propostas de flexibilização.

\section{II.1. Origens próximas ${ }^{105}$}

A Revolução Industrial, iniciada em meados do século XVIII na Inglaterra, espalhou-se para os demais países da Europa, América e Ásia por volta dos anos 1880,

\footnotetext{
${ }^{105}$ Com relação às origens remotas das ações coletivas, valemo-nos da lição de MORI, in verbis: Os doutrinadores divergem sobre as origens das ações coletivas, e durante muito tempo situaram tais origens no Bill of Peace do direito medieval inglês que, no final do século XVII, permitiu aos representantes de determinadas comunas ou segmentos da sociedade, agissem em juízo, perante as Courts of Chancery, em nome de toda a comuna ou segmento social. Normalmente, os autores e réus eram obrigados a comparecer pessoalmente e atuar juntos na defesa de direitos comuns. Entretanto, quando o número de autores, ou de réus, era tão grande que se tornasse impraticável, física ou legalmente, exigir que todos estivessem presentes, a corte permitia que o caso fosse apresentado em nome de todos os potenciais autores, os réus, presentes ou ausentes. Os representantes eram obrigados a demonstrar, logo no início do caso, que representavam adequadamente os interesses do grupo inteiro, porque o julgamento que viesse a ser proferido seria vinculado para todos os indivíduos do grupo, presentes ou ausentes (Zechariah Chafee, Same Problems of Equity, University of Michigan Press, 1950). Permitia-se que uma coleção de réus ou autores, pertencentes a um mesmo grupamento e unidos fossem representados em juízo por um dos integrantes do grupo. Note-se e repita-se: a representação coletiva poderia se dar tanto no pólo ativo, quanto no pólo passivo da ação. Essa permissão foi expressa no artigo 10 do Court of Judicature Act de 1873: 'Havendo multiplicidade de partes podem acionar ou serem acionados ou serem autorizadas pela Corte para litigar em benefício de todas as demais'. O professor Stephen Yeazell, da Universidade da Califórnia, entretanto contestou essa versão no livro From Medieval Group Litigation to the Modern Class Action (Yale University Press, 1950), sustentando que o conceito de grupo litigante surgiu por múltiplas formas, centenas de anos antes de Bill of Peace. Relata que constituía longa tradição na Inglaterra e em outros países da Europa o fato de grupos organizados ou indivíduos precariamente associados formularem pleitos em razão de lesões à comuna, pleitos esses que eram ouvidos e julgados. São citados os exemplos de mercadores manipulando o mercado, pregadores de igrejas diversas perturbando a paz religiosa, ou famílias poderosas intimidando jurados. O mais antigo caso citado por Stephen Yeazell está situado fora da Inglaterra. Em 1179, os aldeões da vila de Rosnysous-Bois reivindicaram aos seus senhores, ao abade e aos clérigos de Santa Genoveva, em Paris, o fim da condição de servos. Estas origens históricas são, além de curiosas, relevantes para se fixar a idéia de que desde sempre o motivo principal para se aceitarem as ações coletivas, de interesses comuns a um determinado grupo, foi evitar a multiplicidade de feitos e evitar que determinadas questões relevantes deixassem de ser julgadas, pela impossibilidade de identificar e reunir todos os interessados (Cf. MORI, Celso Cintra. A litispendência entre ações individuais e ações coletivas em defesa de interesses individuais homogêneos. Revista do Advogado. Ano XXIV, n. 84. São Paulo: AASP, dez. 2005, p. 28 - g.n.).
} 
dando início à era do consumo de massa. A modernização das infra-estruturas de transporte e comunicação, v.g., estradas de ferro, telégrafo e telefone, permitiu o desenvolvimento do comércio de grande escala, abrindo caminho para a sociedade de consumo de massasegundo o filósofo LIPOVETSKY ${ }^{106}$-, o que impactou profundamente a estrutura da sociedade.

Essas transformações não significaram apenas desenvolvimento e progresso, mas trouxeram consigo a explosão demográfica, as grandes concentrações urbanas, a produção e o consumo de massa, as multinacionais, os parques industriais, os grandes conglomerados financeiros e todos os problemas e convulsões inerentes a esses fenômenos sociais.

Tais mudanças fizeram eclodir, no seio da sociedade, novos conflitos, denominados conflitos de massa ou megaconflitos (o mass tort cases, do processo norte-americano) ${ }^{107}$.

O Direito, a exemplo das demais ciências, não podia passar ao largo de tão sensíveis mudanças. Assim é que surge, na Itália, o estudo dos chamados interesses difusos ou coletivos, cujos aspectos fundamentais foram discutidos sobretudo por DENTI, CAPPELLETTI, PROTO PISANI, VIGORITI e TROCKER, no Congresso de Pavia de 1974, destacando suas principais características:

\begin{abstract}
Indeterminados pela titularidade; indivisíveis com relação ao objeto; colocados a meio caminho entre os interesses públicos e os privados [cf. a consagrada lição de Mauro Cappelletti $\left.{ }^{108}\right]$; próprios de uma sociedade de massa e resultado de conflitos de massa; carregados de relevância política e capazes de transformar conceitos jurídicos estratificados ${ }^{109}$.
\end{abstract}

\footnotetext{
${ }^{106}$ LIPOVETSKY, Gilles. A felicidade paradoxal: ensaio sobre a sociedade de hiperconsumo. MACHADO, Maria Lucia (Trad.). São Paulo: Companhia das Letras, 2007, p. 26 e 34.

${ }^{107}$ Cf. MANCUSO, Rodolfo de Camargo. A concomitância entre ações de natureza coletiva. In Direito Processual Coletivo e o Anteprojeto de Código Brasileiro de Processos Coletivos. GRINOVER, Ada Pellegrini, MENDES, Aluisio Gonçalves de Castro e WATANABE, Kazuo (Coords.). São Paulo: Revista dos Tribunais, 2007, p. 162, passim.

${ }^{108}$ Formações sociais e interesses coletivos diante da Justiça Civil. Revista de Processo n. 5, São Paulo: Revista dos Tribunais, 1977.

${ }^{109}$ GRINOVER, Ada Pellegrini. Defesa do meio ambiente em juízo como conquista da cidadania. Revista de Direitos Difusos, v. 2, 2000, p. 121/128.
} 
Trata-se de interesses sociais comuns a um conjunto de pessoas, que comportam ofensas de massa e que colocam em contraste grupos, categorias, classes de pessoas - os corpos intermediários. Esses interesses deram origem a uma nova "geração" de direitos fundamentais. Como ensina PELLEGRINI:

Aos direitos de primeira geração, representados pelas tradicionais liberdades negativas, próprias do Estado liberal, com o correspondente dever de abstenção por parte do Poder Público; aos direitos de segunda geração, de caráter econômico-social, compostos por liberdades positivas, com o correlato dever do Estado a uma obrigação de 'dare', 'facere' ou 'praestare', acrescentou-se o reconhecimento dos direitos de terceira geração, representados pelos direitos de solidariedade, decorrentes dos interesses sociais. E assim foi que, o que aparecia inicialmente como mero interesse, elevou-se à dimensão de verdadeiro direito, conduzindo à reestruturação de conceitos jurídicos, que se amoldassem à nova realidade ${ }^{110}$.

Com efeito, esta nova ordem coletiva apontou a necessidade de reestruturação das regras do direito positivo e processual, em especial a alteração da prestação jurisdicional, que passaria a enfrentar conflitos entre interesses metaindividuais, sem prejuízo das já conhecidas lides individuais. Em uma visão progressista (ou social) da ciência processual, diz-se que o processo, a exemplo do direito material, deve evoluir conforme as mudanças sociais trazidas pelos novos tempos. Assim, nesse contexto de efervescência e constante mutação das relações sociais, surge a necessidade de pacificar conflitos relacionados a esse fenômeno por meio do processo coletivo.

Nas palavras de CAPPELLETTI e GARTH:

A concepção tradicional do processo civil não deixava espaço para a proteção dos direitos difusos. O processo era visto apenas como um assunto entre duas partes, que se destinava à solução de uma controvérsia entre essas mesmas partes a respeito de seus próprios interesses

${ }^{110}$ GRINOVER, Ada Pellegrini. Defesa..., op. cit.. 
individuais. Direitos que pertencessem a um grupo, ao público em geral ou a um segmento do público não se enquadravam bem nesse esquema ${ }^{111}$.

Em adição, VIGORITI salienta que "não se podem resolver problemas de dimensão superindividual (...) pensando sempre na controvérsia apenas do Tício contra o Caio"112. Nesse sentido, justifica-se um redimensionamento do processo civil, para atender às peculiaridades dos conflitos existentes na sociedade moderna. Afinal, como indaga BARBOSA MOREIRA, se temos produção de massa, distribuição de massa, cultura de massa, comunicação de massa, por que não processo de massa? E somente por meio da releitura dos instrumentos processuais clássicos será possível dar voz e voto a esses interesses a non domino, mas socialmente muito relevantes ${ }^{113}$.

A esse respeito, NERY JR. ressalta que "As soluções do direito privado tradicional, bem como do processo civil ortodoxo não mais atendem às necessidades do povo brasileiro quanto aos conflitos metaindividuais" ${ }^{\prime 114}$. Na visão do autor, isso explica porque esses conflitos requerem a aplicação de regras específicas de processo civil coletivo.

A título de exemplo, citem-se as condições da ação, que, nas demandas coletivas, são mais complexas: a legitimação ativa é extraída a partir do binômio representatividade adequada + relevância social do interesse metaindividual; o interesse de agir requer, em alguns casos, a conferência da pertinência temática, além da superioridade do trato coletivo da matéria (em face da jurisdição singular); e a possibilidade jurídica do pedido é mais ampla, tendo em vista que muitos podem ser os interesses metaindividuais (art. $1^{\mathrm{o}}$, da Lei n. $7.347 / 85)$.

\footnotetext{
${ }^{111}$ CAPPELLETTI, Mauro e GARTH, Bryant. Acesso à justiça. Porto Alegre: Fabris, 1998, p. 49.

${ }^{112}$ VIGORITI, Vincenzo. Interessi coletivi e processo: La legittimazione ad agire. Milão: Giuffrè, 1979, p. 225. No mesmo sentido, MANCUSO assevera que "quando essas massas de interesses sem dono certo (...) entram em conflito com outras massas também de largo espectro, o conflito escapa totalmente aos limites e características das conhecidas disputas intersubjetivas de tipo Tício versus Caio, de que se ocupa a jurisdição singular" (In A concomitância de ações coletivas, entre si, e em face das ações individuais. Revista dos Tribunais, ano 89, v. 782, São Paulo, dez. 2000, p. 27/28, passim).

${ }^{113}$ Cf. MANCUSO, Rodolfo de Camargo. A concomitância de ações coletivas, entre si..., op. cit., p. 27/28.

${ }^{114}$ NERY JUNIOR, Nelson. O Ministério Público e as Ações Coletivas. In Ação Civil Pública: Lei 7.347/85 - reminiscências e reflexões após 10 anos de aplicação. MILARÉ, Édis (Coord.). São Paulo: Revista dos Tribunais, 1995, p. 365. No mesmo sentido, GIDI adverte que "muitos problemas na aplicação do direito seriam causados se fizéssemos o 'transplante' puro e simples - sem as necessárias adaptações - do regime jurídico da coisa julgada nas ações individuais para as ações coletivas" (In Coisa julgada e litispendência em ações coletivas. São Paulo: Saraiva, 1995, p. 14 e 57).
} 
Por essas e outras peculiaridades, já se tornou quase pacífico, hoje, que não é possível tutelar direitos coletivos "por intermédio das regras do direito processual civil clássico, as quais foram concebidas por uma filosofia liberal-individualista arraigada, no final do séc. XIX"115.

\section{II.2. Microssistema processual coletivo}

Nessa esteira, a história do Direito Processual Coletivo brasileiro, embora inspirada no sistema das class actions da common law, estruturou-se em técnicas próprias, mais adequadas à nossa realidade social e política.

De início, merece destaque a Lei n. 4.717/65, que rompeu paradigmas ao criar a Ação Popular, a ser proposta por qualquer cidadão no gozo de seus direitos políticos, para defesa do patrimônio público, em benefício de toda a coletividade.

Na seqüência, entraram em vigor as Leis n. 7.347/85, Lei da Ação Civil Pública (“LACP”), e n. 8.078/90, Código de Defesa do Consumidor (“CDC"), as quais se integram e se complementam, formando, em conjunto com a Lei da Ação Popular, um verdadeiro microssistema processual coletivo ${ }^{116}$, especificamente destinado à tutela dos interesses difusos, coletivos e individuais homogêneos.

Em adição, a Constituição Federal de 1988 criou o Mandado de Segurança Coletivo, para a defesa de direito líquido e certo concernente à coletividade como um todo ou a grupo, categoria ou classe de pessoas, além de prever as Ações de Controle de Constitucionalidade (Ação Direta de Inconstitucionalidade e Ação Declaratória de Constitucionalidade).

\footnotetext{
115 ASSAGRA, Gregório de Almeida. Direito Processual Coletivo Brasileiro - Um novo ramo do Direito Processual. São Paulo: Saraiva, 2004, p. 17.

116 Sobre a complementaridade desses três diplomas legais, vide MANCUSO, Rodolfo de Camargo. Ação popular: proteção do erário, do patrimônio público, da moralidade administrativa e do meio ambiente. São Paulo: Revista dos Tribunais, 2003, p. 38, passim. Note-se que essa 'via de interação' entre referidos diplomas não só foi amplamente reconhecida pela doutrina, como, instituída pelo próprio legislador, no artigo 21 da Lei 7.347/85, com a redação que lhe foi dada pelo artigo 117 da Lei 8.078/90.
} 
É preciso reconhecer que "as ações coletivas ganharam, na Constituição Federal de 1988, dimensões até então desconhecidas no Direito Constitucional brasileiro" ${ }^{117}$. Como exemplifica BARBOSA MOREIRA, a nova ordem constitucional destacou as figuras do Mandado de Segurança Coletivo (art. 5, LXX), da Ação Popular (art. 5, LXXIII), da Ação Civil Pública (art. 129, III, e $\S 1^{\circ}$ ), e da legitimação de associações e sindicatos para tutela dos interesses dos seus membros (art. $5^{\circ}$, XXI e art. $8^{\circ}$, VI, respectivamente).

Não resta dúvida de que o microssistema processual coletivo modernizou institutos tradicionais e individualistas do processo civil, alterando profundamente alguns institutos básicos, de resto inadequados à tutela dos interesses metaindividuais ${ }^{118}$. De fato, as demandas coletivas diferem das individuais, na medida em que: (i) a legitimação para agir é extraordinária, sob a forma concorrente-disjuntiva, facultando-se a vários co-legitimados a propositura de ação, em nome próprio, no interesse da coletividade; (ii) a coisa julgada é erga omnes ou ultra partes ${ }^{119}$, ampliando-se os limites subjetivos do julgado; (iii) o objeto é indivisível, o que confere aos interesses metaindividuais tratamento unitário, de forma que a satisfação de um interessado implica necessariamente a satisfação de todos, dentre outras peculiaridades.

Referido microssistema processual coletivo, todavia, não prescinde da aplicação subsidiária do CPC, naquilo que não conflitar com as normas especiais da tutela processual coletiva $^{120}$, evidentemente.

\footnotetext{
${ }^{117}$ Conforme BARBOSA MOREIRA, José Carlos. Ações coletivas na Constituição Federal de 1988. Revista de Processo. n. 62. São Paulo: Revista dos Tribunais, jan./mar. 1991, p. 190, passim.

${ }^{118}$ É certo que existe farta discussão doutrinária acerca da terminologia a ser empregada: 'interesse simples', 'interesse legítimo', 'direito subjetivo individual' ou 'direito subjetivo transindividual' (para maior desenvolvimento do tema, vide MANCUSO, Rodolfo de Camargo. Interesses difusos - conceito e legitimação para agir. São Paulo: Revista dos Tribunais, 2004, p. 19/81; e LENZA, Pedro. Teoria Geral da Ação Civil Pública. São Paulo: Revista dos Tribunais, 2005, p. 47/56). Em que pese isso, o presente trabalho emprega as expressões como sinônimas, tendo em vista que, do ponto de vista prático, o 'interesse', a partir do momento em que passa a ser amparado/tutelado juridicamente, assume o status de 'direito' (cf. WATANABE, Kazuo. Código Brasileiro de Defesa do Consumidor comentado pelos autores do Anteprojeto. Rio de Janeiro: Forense Universitária, 2004, p. 800/801; e BARBOSA MOREIRA, José Carlos. A ação popular no direito brasileiro como instrumento de tutela jurisdicional dos chamados interesses difusos'. Temas de direito processual, primeira série. São Paulo: Saraiva, 1977, p. 113/114).

${ }^{119}$ Como salienta GRINOVER, Ada Pellegrini: a "coisa julgada erga omnes é uma exigência do próprio tratamento coletivo. De nada serviria tratar esses bens e interesses coletivamente, se não houvesse uma qualidade de imutabilidade da sentença que se projetasse com relação a todas aquelas pessoas que podem ser beneficiadas por esta sentença" (A coisa julgada perante a Constituição, a Lei da Ação Civil Pública, o Estatuto da Criança e do Adolescente e o Código de Defesa do Consumidor. O processo em evolução. Rio de Janeiro: Forense Universitária, 1996, p. 148-149).

${ }^{120}$ Nos termos dos artigos 19 da Lei da Ação Civil Pública e 90 do Código de Defesa do Consumidor.
} 


\section{II.3. Visão geral sobre os interesses metaindividuais: difusos $x$ coletivos (stricto sensu) $x$ individuais homogêneos}

Em sua clássica lição, BARBOSA MOREIRA subdivide os interesses metaindividuais em duas espécies: (i) os essencialmente coletivos; e (ii) os acidentalmente coletivos $^{121}$. Na primeira espécie estão os interesses difusos e coletivos (stricto sensu), e, na segunda, os individuais homogêneos.

Importa salientar, de início, que esses "feixes" de interesse não são excludentes entre si, sendo possível que um mesmo fato lesivo tenha diferentes graus de repercussão, dependendo de que ângulo seja analisado. Assim, v.g., pode-se pensar tanto no caso da embarcação Bateau Mouche IV (exemplo citado por $\mathrm{NERY}^{122}$ ), quanto no caso de contaminação de um curso d'água por agentes tóxicos (exemplo citado por SALLES ${ }^{123}$ ), para constatar-se que, de um mesmo fato/conduta, poderão advir interesses difusos (recuperação da qualidade do recurso hídrico), coletivos em sentido estrito (associação de horticultores que se viram privados do uso da água) e individuais homogêneos (moradores que contraíram doenças devido aos agentes carcinogênicos despejados no curso d'água).

Visto isso, cumpre analisar, inicialmente, os interesses essencialmente coletivos, que se caracterizam, no aspecto objetivo, pela indivisibilidade do objeto e, no aspecto subjetivo, pela pluralidade de sujeitos indeterminados ou indetermináveis. Nos termos do artigo 81 do $\mathrm{CDC}$, os interesses difusos e coletivos apresentam, em comum, a transindividualidade e a indivisibilidade do objeto, de tal forma que a satisfação do direito por parte de um membro da coletividade implica, necessariamente, a satisfação de todos.

\footnotetext{
${ }^{121}$ BARBOSA MOREIRA, José Carlos. Ações coletivas na Constituição..., op. cit., , p. 187. Ou, segundo ZAVASCKI, a diferenciação também pode ser feita entre (i) tutela de direitos coletivos; e (ii) tutela coletiva de direitos (In Tutela de Direitos Coletivos e Tutela Coletiva de Direitos. São Paulo: Revista dos Tribunais, 2008).

${ }^{122}$ NERY JR., Nelson. Código Brasileiro de Defesa do Consumidor..., op. cit., p. 1.016/1.017.

${ }^{123}$ SALLES, Carlos Alberto de. Tese (Doutorado). 24.06.1998. Orientador: Prof. Dr. Kazuo Watanabe. São Paulo, 1998. Faculdade de Direito, Universidade de São Paulo, p. 137/139, passim.
} 
O que os diferencia é o aspecto subjetivo: nos interesses difusos, os membros da coletividade estão ligados apenas por circunstâncias fáticas, comuns a todos, não havendo um vínculo jurídico entre eles, o que os torna indetermináveis; ao passo que nos interesses coletivos existe um grupo, categoria ou classe de pessoas determinadas ou determináveis, ligadas entre si ou com a parte contrária por uma relação jurídica-base.

Tendo em vista o recorte feito no presente trabalho, voltado às ações ambientais, merecem destaque os interesses difusos, assim definidos por MANCUSO:

São interesses metaindividuais, que, não tendo atingido o grau de agregação e organização necessários à sua afetação institucional junto a certas entidades ou órgãos representativos dos interesses já socialmente definidos, restam em estado fluido, dispersos pela sociedade civil como um todo (v.g., os consumidores). Caracterizam-se: pela indeterminação dos sujeitos, pela indivisibilidade do objeto, por sua intensa litigiosidade interna e por sua tendência à transição ou mutação no tempo e no espaço $^{124}$.

Já os interesses acidentalmente coletivos são os individuais homogêneos, que se distinguem dos difusos e coletivos por serem direitos tipicamente individuais e, portanto, divisíveis. $\mathrm{O}$ aspecto coletivo está no tratamento processual que recebem, com vistas a facilitar o acesso à justiça e a evitar a multiplicidade de feitos repetitivos.

Apesar de serem mais recorrentes nas relações de consumo, os interesses individuais homogêneos também emergem de questões ambientais, como ocorre, por exemplo, no caso do chamado dano ricochete, que são danos individualmente sofridos pelas vítimas de acidentes ecológicos, "a reboque" do dano coletivo. Exemplo clássico vamos encontrar na hipótese de poluição de um rio pelo lançamento de efluentes sem tratamento: além do dano coletivo causado ao bem ambiental (poluição do recurso hídrico), pescadores podem ver-se obrigados a paralisar suas atividades por conta da contaminação dos peixes, perdendo sua fonte de sustento, ainda que temporariamente ${ }^{125}$.

${ }^{124}$ MANCUSO, Rodolfo de Camargo. Interesses Difusos: conceito e legitimação para agir. São Paulo: Revista dos Tribunais, 2004, p. 150, passim (g.n.).

${ }^{125} \mathrm{Da}$ mesma forma, a poluição do rio pode acarretar a mortandade de um rebanho, após a utilização da água (contaminada) para dessedentação dos animais, causando um dano individual/ricochete ao proprietário. 
Os prejuízos advindos da paralisação forçada da pesca têm inegável natureza individual e, por terem origem comum, podem ser tutelados tanto coletiva quanto individualmente.

Nas palavras de GRINOVER, tais interesses compreendem direitos subjetivos divisíveis, titularizados por pessoas determinadas, tratados apenas a título individual (ou, quanto muito, pela figura do litisconsórcio), mas que, a partir de agora são "passíveis de reunião num único processo, em virtude de sua homogeneidade, decorrente de uma origem comum" ${ }^{\prime 26}$. Por certo, o tratamento coletivo de interesses individuais vem justificado, dentre outros fundamentos, pelo fato de que os conflitos relativos a um número muito expressivo de sujeitos (os ditos megalitígios) podem não ser aceitos no Judiciário por força do artigo 47 do CPC, que permite ao juiz limitar a formação do litisconsórcio multitudinário.

Assim, quando houver uma extraordinária dispersão dos interessados, melhor será enquadrar esses conflitos na jurisdição coletiva ${ }^{127}$. A condução coletiva do processo não retira a característica dos interesses individuais homogêneos de constituírem-se direitos subjetivos clássicos, divisíveis por natureza, sendo sempre permitido aos membros do grupo demandar individualmente.

Dentre outras vantagens, a tutela coletiva de interesses individuais de origem comum também é recomendável porque, uma vez reunidos, eles assumem uma dimensão coletiva, superior à soma dos interesses individuais, ganhando força e relevância social. Com efeito, "a soma, neste caso, seria algo mais do que simplesmente o conjunto de parcelas, exatamente porque o fenômeno assume, no contexto da vida social, um impacto de massa" ${ }^{128}$. Essa "mais-valia" está, justamente, na maior significação jurídico-social que o conflito atinge, ao ser encarado coletivamente, pois aí ele se apresenta como um impacto de massa.

\footnotetext{
${ }^{126}$ GRINOVER, Ada Pellegrini. Ação coletiva fortalece proteção. O Estado de S. Paulo, de 14.12.1991, Caderno Justiça, p. 8

${ }^{127}$ A esse respeito, MANCUSO lembra que, na Justiça do Trabalho, as controvérsias que transbordam o âmbito do contrato individual, atingindo os sujeitos componente de uma dada categoria, são encaminhadas nos moldes de dissídio coletivo - art. 857, CLT (In A concomitância de ações coletivas, entre si..., op. cit., p. 25).

${ }^{128}$ BARBOSA MOREIRA, José Carlos. Ações coletivas na Constituição..., op. cit., p. 188/189.
} 
Em reforço, MANCUSO ressalta que "na ação coletiva o interesse que constitui o objeto litigioso está sendo judicializado em sua dimensão metaindividual, com abstração, pois, dos sujeitos concernentes" ${ }^{\prime 29}$. Sobre o assunto, o autor cita decisão judicial na qual se consignou: "o excesso transforma a quantidade, emprestando-lhe outra qualidade"130.

Na consagrada expressão de WATANABE, a tutela coletiva atinge o escopo de molecularizar conflitos, hoje atomizados. Essa molecularização, a um só tempo, confere maior peso político às decisões proferidas em sede de demanda coletiva, soluciona mais adequadamente os conflitos dessa natureza, evita decisões conflitantes e alivia a sobrecarga do Poder Judiciário (atulhado de demandas fragmentárias), o que contribui para atingir-se maior uniformidade e eficácia mais potenciada de nossas Cortes de Justiça ${ }^{131}$.

De fato, a tutela coletiva de direitos é importante fator de economia judicial $e$ processual. Segundo MENDES, as ações coletivas contribuem para diminuir o número de demandas ajuizadas, originárias de fatos comuns e que acabam provocando acúmulo de processos. Com isso, "as ações coletivas poderão oferecer, também, maior segurança para a sociedade, na medida em que estaremos evitando a prolação de decisões contraditórias em processos individuais, em benefício da preservação do próprio princípio da isonomia" $" 132$.

MATTOS bem retrata os propósitos das ações coletivas ao dispor que:

A ação coletiva é criação jurídica projetada para a solução molecular, concentrada, em um único processo, de diversas lides derivadas de uma origem comum, que não devem esfarelar-se em numerosos e prescindíveis processos de conteúdo essencialmente idêntico ${ }^{133}$.

\footnotetext{
${ }^{129}$ MANCUSO, Rodolfo de Camargo. A concomitância de ações coletivas, entre si..., op. cit., p. 41.

${ }^{130}$ Decisão do Juiz José Eduardo Santos Neve, citada pelo Juiz Federal Victorio Giuzio Neto, nos autos da Ação Civil Pública nº 2000.61.00.033627-1.

131 WATANABE, Kazuo. Demandas Coletivas e os problemas emergentes da práxis forense. Revista de Processo, n. 67, jul./set. 1992, p. 19 e 23, passim.

${ }^{132}$ MENDES, Aluísio Gonçalves de Castro. O Código Modelo de Processos Coletivos. In Tutela Coletiva20 anos da Lei da Ação Civil Pública e do Fundo de Defesa de Direitos Difusos e 15 anos do Código de Defesa do Consumidor. LUCON, Paulo Henrique dos Santos (Coord.). São Paulo: Atlas, 2006, p. 46.

${ }^{133}$ MATTOS, Luiz Norton Baptista de. A litispendência e a coisa julgada nas ações coletivas segundo o Código de Defesa do Consumidor e os anteprojetos do Código Brasileiro de Processos Coletivos. In Direito Processual Coletivo e o Anteprojeto de Código Brasileiro de Processos Coletivos. GRINOVER, Ada Pellegrini, MENDES, Aluisio Gonçalves de Castro e WATANABE, Kazuo (Coords.). São Paulo: Revista dos Tribunais, 2007, p. 207.
} 
Em suma, pode-se dizer que os escopos das ações coletivas são: (i) a eliminação de decisões conflitantes sobre o mesmo tema jurídico ou fático, conferindo maior credibilidade às decisões; (ii) a diminuição do número excessivo de processos, permitindo maior qualidade nos julgamentos e com mais celeridade.

A esse respeito, vale uma pequena digressão para traçar um paralelo com as recentes inovações ocorridas no processo civil individual, como os mecanismos de contenção de recursos introduzidos pela Emenda Constitucional n. $45 / 04^{134}$ e pelas Leis n. 11.276/06 (súmula impeditiva de recurso), n. 11.277/06 (precedentes do juízo monocrático), n. 11.417/06 (súmula vinculante), n. 11.418/06 (repercussão geral) e n. 11.672/08 (recursos repetitivos no Superior Tribunal de Justiça). Passados vinte anos desde o boom do acesso à ordem jurídica justa, o que se vê são tendências doutrinárias, jurisprudenciais e legislativas no sentido de reduzir o volume de trabalho dos órgãos jurisdicionais.

O primeiro passo para tanto foi reconhecer que grande parte dos processos que afogam o Poder Judiciário discutem as mesmas questões de direito, tratando-se de demandas idênticas e repetitivas, para as quais, muitas vezes, bastaria uma única ação coletiva. Como salienta BARBOSA MOREIRA: “dezenas, centenas de processos, onde se discutem as mesmíssimas questões, para a Justiça constituem um fator de sobrecarga, e portanto, de retardamento da prestação jurisdicional"135.

A partir dessa constatação, nosso sistema passou por profundas reformas, que atribuíram cada vez mais força aos precedentes, à jurisprudência e às súmulas, em uma verdadeira escalada - partindo-se dos precedentes do próprio juízo monocrático, passando pelas súmulas persuasivas editadas pelos tribunais, pelos poderes do relator, pelas súmulas impeditivas de recurso, pela necessidade de repercussão geral para a admissibilidade de recurso extraordinário, que poderá ser aferida "por amostragem", até se chegar às súmulas vinculantes.

\footnotetext{
134 "A súmula terá por objetivo a validade, a interpretação e a eficácia de normas determinadas, acerca das quais haja controvérsia atual entre órgãos judiciários ou entre esses e a administração pública que acarrete grave insegurança jurídica e relevante multiplicação de processos sobre questão idêntica" (artigo 103-A, $\S 1^{\circ}$, da CF).

${ }_{135}$ BARBOSA MOREIRA, José Carlos. Ações coletivas na Constituição..., op. cit., p. 199.
} 
A utilização desses institutos, na visão MANCUSO, é positiva, uma vez que se trata de "inadiável adoção de medida idônea a conter a caótica dispersão de ações judiciais sobre um mesmo tema", o que acarreta conseqüências perversas, "tanto para o Estado-juiz, que se vê assoberbado com a sobrecarga do serviço, quanto para o jurisdicionado, que recebe uma resposta tardia e de conteúdo imprevisível"136.

E prossegue o autor: “a utilidade maior que se pode alcançar através da súmula vinculante é a realização prática do binômio justiça-certeza, que constitui o cerne do próprio Direito e a razão de ser da atividade judiciária do Estado" ${ }^{\text {"137. }}$

De fato, quer-nos parecer que a escolha do legislador foi acertada, na medida em que foram privilegiadas, a um só tempo, a segurança jurídica (previsibilidade dos julgamentos e fim da "loteria" judicial); a isonomia (mesma resposta para quem se encontra em situações idênticas); a celeridade nos julgamentos e a economia processual enfim, a efetividade do processo, além do caráter preventivo desses institutos, que tendem a desestimular a interposição de recursos e desencorajar a propositura de ações contrárias à jurisprudência dominante.

A bem ver, portanto, a jurisdição coletiva vai ao encontro dos mais legítimos anseios da sociedade, uma vez que também proporciona segurança jurídica, isonomia, celeridade e economia processual, estando em conformidade com as recentes reformas por que passou o Processo Civil - em que pese ter sido pensada e estruturada há mais de vinte anos.

\footnotetext{
${ }^{136}$ MANCUSO, Rodolfo de Camargo. Divergência jurisprudencial e súmula vinculante. São Paulo: Revista dos Tribunais, 2007, p. 331.

${ }^{137}$ Idem, ibidem, p. 334.
} 


\section{II.4. A tutela do meio ambiente em juízo}

Dentre as espécies de interesses metaindividuais, o presente trabalho dá destaque ao interesse difuso por excelência: o meio ambiente. Sua proteção jurídica teve início, no Brasil, há pouco mais de três décadas e assume importância cada vez maior, como é notório e intuitivo.

Em todo o mundo, a preocupação com o meio ambiente cresce a cada dia. Mais e mais, deparamo-nos com inúmeros e variados problemas ambientais à nossa volta, o que reforça a necessidade de buscarmos um desenvolvimento com sustentabilidade, no lugar da antiga bandeira do "crescimento a qualquer custo". A importância da temática ambiental cresce à medida que a humanidade torna-se consciente de que a sobrevivência da espécie humana depende da "saúde" do planeta e que os recursos naturais são finitos - e cada vez mais escassos. Daí se dizer que preservar e restabelecer o equilíbrio ecológico são questões de vida ou morte. A respeito do agravamento das lesões aos recursos ambientais ${ }^{138}$, MILARÉ lembra que "nossa casa" nunca esteve tão suja e doente:

O ar está mais contaminado, a água mais corrompida e escassa, a área florestal menor, os desertos maiores, o patrimônio genético se degradando. Devido à nossa maneira atual de viver, nossas civilizações correm risco. Os mais de 6 bilhões de pessoas vivas, sobretudo 1 bilhão nos países mais abastados, estão fazendo mau uso dos recursos naturais e sobrecarregando seriamente os ecossistemas da Terra ${ }^{139}$.

As conseqüências dessa crise ambiental são imprevisíveis (para não dizer catastróficas) e podem acarretar, até mesmo, uma limitação do processo evolutivo, "comprometendo inclusive a viabilidade de sobrevivência de grandes contingentes populacionais da espécie humana" ${ }^{\# 140}$. Diante desse quadro, devemos lançar mão de alguns

\footnotetext{
${ }^{138}$ Frise-se que os recursos ambientais abrangem um conjunto amplo de recursos, incluindo não só os elementos naturais, como também os artificiais e culturais.

${ }^{139}$ Cuidando do Planeta Terra: uma estratégia para o futuro da vida. São Paulo, publicação conjunta de UICN - União Internacional para Conservação da Natureza, PNUMA - Programa das Nações Unidas para o Meio Ambiente e WWF - Fundo Mundial para a Natureza (Governo do Estado de São Paulo/SP, ECO 92), 1991, p. 3. Apud MILARÉ, Édis. Direito do Ambiente. São Paulo: Revista dos Tribunais, 2007, p.731.

140 ERICKSON, John. Nosso planeta está morrendo. SANTOS, José Carlos Barbosa dos (Trad.). São Paulo: Makron/McGraw-Hill, 1992, p. 210.
} 
instrumentos para nos auxiliar na superação da crise. Ao lado dos consagrados instrumentos de Gestão Ambiental ${ }^{141}$ está o Direito, como ferramenta apta a coibir (pelo menos em tese) o agravamento da degradação ambiental, seja com regras coercitivas, seja com a imposição de penalidades.

No Brasil, o regramento jurídico de proteção do ambiente é bastante vasto e digno de elogio - o problema está na sua implementação... -, com destaque para os seguintes diplomas, que constituem os grandes marcos do nosso Direito Ambiental: (i) a Lei n. 6.938, de 31.08.1981, que instituiu a Política Nacional do Meio Ambiente; (ii) a Lei n. 7.347, de 24.07.1985, que trata da Ação Civil Pública; (iii) a Constituição Federal da República, de 05.10.1988; e (iv) a Lei n. 9.605, de 12.02.1998, também conhecida como Lei de Crimes Ambientais.

A Constituição Federal de 1988 inaugurou uma nova era para a proteção jurídica do meio ambiente, conferindo-lhe status constitucional pela primeira vez na história. Por força do art. 225, caput, o "meio ambiente ecologicamente equilibrado" é considerado "bem de uso comum do povo" e, destarte, "direito de todos", inclusive das futuras gerações.

Não por outro motivo a doutrina leciona que os danos ambientais atingem interesses difusos, na medida em que afetam diretamente uma coletividade indeterminada ou indeterminável de titulares. "Os direitos decorrentes dessas agressões caracterizam-se pela inexistência de uma relação jurídica base, no aspecto subjetivo, e pela indivisibilidade (...) do bem jurídico, diante do aspecto objetivo"142. De fato, a lesão ambiental afeta, sempre e necessariamente, uma pluralidade difusa de vitimas, ainda que alguns indivíduos sejam mais diretamente atingidos.

Daí se dizer que "nenhum outro interesse tem difusão maior do que o meio ambiente, que, como é curial, pertence a todos em geral e a ninguém em particular; sua proteção a todos aproveita, e sua postergação a todos em conjunto prejudica"143. Essa, aliás, é uma das justificativas para o recorte feito no presente trabalho.

\footnotetext{
${ }^{141}$ Elencados no artigo $9^{\circ}$ da Lei $6.938 / 81$.

142 CARVALHO, Délton Winter de. A proteção jurisdicional do meio ambiente: uma relação jurídica comunitária. Revista de Direito Ambiental, São Paulo: Revista dos Tribunais, n. 24, p. 197, 2001.

${ }^{143}$ FERRAZ, Sérgio. Responsabilidade civil por dano ecológico. Revista de Direito Público, São Paulo: 1979, v. 49-50, p. 35. Apud MILARÉ, Édis. Direito..., op. cit., p. 1.009.
} 
Dada a significância do bem jurídico ambiental, o artigo 225, $\S 3^{\circ}$, da Constituição Federal tratou da chamada tríplice responsabilidade ambiental, dispondo que "as condutas e atividades consideradas lesivas ao meio ambiente sujeitarão os infratores, pessoas físicas ou jurídicas, a sanções penais e administrativas, independentemente da obrigação de reparar os danos causados". A bem ver, ao lado da tutela preventiva, o constituinte consagrou as tutelas repressiva e reparatória do ambiente.

Para o nosso exame, merece destaque a responsabilidade civil pela reparação dos danos causados ao meio ambiente. Como regra geral, a tutela reparatória segue as normas de responsabilidade civil, que, no Direito comum, segue o regime da responsabilidade civil subjetiva, fundada na culpa ou dolo do agente, na existência do dano (ou da lesão), e do nexo de causalidade entre o dano e a conduta. Em matéria ambiental, ao contrário, a responsabilidade civil é objetiva, consoante artigo $14, \S 1^{\circ}$, da Lei n. 6.938/81, in verbis: “(...) é o poluidor ${ }^{144}$ obrigado, independentemente da existência de culpa, a indenizar ou reparar os danos causados ao meio ambiente e a terceiros, afetados por sua atividade".

Como conseqüência da adoção desse regime, pode-se dizer que a responsabilidade civil ambiental depende, apenas e tão somente, da presença de dois elementos: (i) o dano ambiental; e (ii) o nexo de causalidade entre a lesão e uma determinada atividade ${ }^{145}$.

Em adição, importa destacar que a responsabilidade civil ambiental é solidária, de tal forma que todos aqueles que, direta ou indiretamente, contribuíram para o evento danoso respondem igualmente pela sua reparação. Mais do que isso, a responsabilidade solidária admite que um único co-obrigado responda pela integralidade da obrigação - essa peculiaridade terá relevância para o exame da relação entre demandas coletivas, com foco no pólo passivo.

\footnotetext{
${ }^{144}$ Por 'poluidor' entenda-se: qualquer pessoa física ou jurídica, de direito público ou privado, que, direta ou indiretamente, der causa ao dano ambiental (art. $3^{\circ}$, IV, da referida Lei).

${ }^{145}$ Nesse sentido, a Súmula 18 do Conselho Superior do Ministério Público do Estado de São Paulo atesta que: "Em matéria de dano ambiental, a Lei $\mathrm{n}^{\circ}$ 6.938/81 estabeleceu a responsabilidade objetiva, o que afasta a investigação e a discussão da culpa, mas não se prescinde de nexo causal entre o dano havido e a ação ou omissão de quem cause o dano. Se o nexo não é estabelecido, é caso de arquivamento do inquérito civil ou das peças de informação".
} 
Tal qual ocorrido no plano do direito material, em que o legislador percebeu que as regras clássicas de responsabilidade, contidas na legislação civil tradicional, não ofereciam proteção suficiente e adequada às vítimas do dano ambiental, o direito processual também reclamava por sensíveis mudanças, tendo em vista que os institutos ortodoxos do Direito Processual clássico, voltados à composição do dano individualmente sofrido, não se mostravam aptos a tutelar os direitos transindividuais. Afinal, em uma sociedade de massa, repita-se, há que existir igualmente um processo civil de massa, tendo em vista que os direitos conferidos no plano material só fazem sentido quando o ordenamento jurídico coloca nas mãos de seus titulares, ou de seus representantes ideológicos, mecanismos efetivos para seu exercício ${ }^{146}$.

Assim, com esteio na Lei n. 6.938/81, que já concedia legitimação ao Ministério Público para a ação de responsabilidade civil contra o poluidor por danos causados ao meio ambiente $^{147}$, editou-se a Lei n. 7.347/85, que disciplina a 'Ação Civil Pública de responsabilidade por danos causados ao meio ambiente, ao consumidor, a bens e direitos de valor artístico, estético, histórico, turístico e paisagístico e dá outras providências'. Referida lei significou uma verdadeira revolução na ordem jurídica brasileira, abrindo espaço para que o processo civil, até então voltado à defesa de interesses individuais, se tornasse um efetivo mecanismo de participação da sociedade na tutela dos interesses metaindividuais.

A seguir, a Lei n. 8.078/90, que instituiu o CDC, em sua parte processual, não só alterou a Lei n. 7.347/85, como ampliou, em muito, o tratamento coletivo dos litígios de massa.

Assim, o microssistema processual coletivo integrado pela LACP e pelo CDC passou a cuidar da tutela jurisdicional de interesses transindividuais, "de início compreensivos dos difusos e dos coletivos em sentido estrito, aos quais na seqüência se agregaram os individuais homogêneos (Lei n. 8.078/90, art. 81, III, c/c os arts. 83 e $117)^{, 148}$.

\footnotetext{
${ }^{146}$ MILARÉ, Édis. Direito..., op. cit., p. 997/998.

${ }^{147}$ Lei 6.938/81, art. 14, $\S 1^{\circ}$, in fine: "O Ministério Público da União e dos Estados terá legitimidade para propor ação de responsabilidade civil e criminal, por danos causados ao meio ambiente".

${ }_{148}$ MANCUSO, Rodolfo de Camargo. Ação Civil Pública - em defesa do meio ambiente, do patrimônio cultural e dos consumidores. São Paulo: Revista dos Tribunais, 2007, p. 22, passim.
} 
Vale lembrar, por fim, que a tutela jurisdicional do meio ambiente é mais uma das instâncias decisórias de salvaguarda desse importante bem difuso, ao lado dos processos político e de mercado (decision-making institution). A via jurisdicional, porém, destaca-se como a instância decisória mais bem ajustada para decidir questões ambientais, comparativamente às outras duas, em razão de suas características de independência e imparcialidade. Como pondera SALLES: “em virtude de sua colocação entre os demais centros de poder social, o Poder Judiciário, na decisão de casos concretos, tem por característica decidir quem decide em relação a um dado problema"149, e ao juízo ainda é reservada a opção de realizar por si mesmo um determinado valor social.

\section{II.5. Pontos nevrálgicos das ações coletivas}

Visto isso, cumpre adentrarmos nas questões processuais afetas à proteção do meio ambiente e dos demais interesses coletivos lato sensu. Desde logo, dois esclarecimentos: a análise dos pontos nevrálgicos das ações coletivas tem (i) como finalidade: auxiliar no estudo da relação entre demandas coletivas; e (ii) como foco: os interesses difusos, tendo em vista a ênfase dada pelo presente trabalho às ações por danos ambientais. Referido escopo justifica, assim, o tratamento sucinto dado a temas como a legitimação para agir, a indivisibilidade do objeto e a coisa julgada nas demandas coletivas, os quais, certamente, poderiam ser desenvolvidos de maneira bastante detalhada, dada sua alta complexidade, mas não o serão, em função do recorte metodológico do presente trabalho.

\section{II.5.1. Legitimidade para agir}

Como visto, a característica marcante dos interesses de "terceira geração" diz respeito à sua metaindividualidade, isto é, ao fato de tais interesses dizerem respeito a uma pluralidade de sujeitos indeterminados ou indetermináveis, a qual transcende/perpassa a órbita dos indivíduos que a compõem. Por pertencerem a todos e a ninguém ao mesmo tempo, tais interesses reclamam um "porta-voz" que os represente adequadamente.

${ }^{149}$ SALLES, Carlos Alberto de. Execução judicial de obrigação..., op. cit., p. 97/98. 
Como se sabe, no sistema processual clássico instituído pelos artigos $3^{\circ}$ e $6^{\circ}$ do CPC, é preciso haver pertinência subjetiva da ação, devendo coincidir o titular da pretensão de direito material com aquele que vem a juízo (= autor). Há casos, porém, em que, por expressa disposição de lei, é possível litigar, em nome próprio, sobre direito alheio. É o que ocorre com a LACP, que conferiu o poder de provocar o Judiciário para a defesa de interesses transindividuais a "terceiros" (entes que ostentam um mínimo de representatividade), não havendo coincidência entre o titular do bem lesado (= coletividade) e o sujeito do processo. Essa sistemática mostra-se muito mais adequada para a defesa dos interesses metaindividuais, uma vez que não é possível que o titular do direito material venha a juízo defender interesse próprio. Nesse sentido, MANCUSO pontua que:

\begin{abstract}
Quando o embate é entre interesses metaindividuais (sujeitos indeterminados/objeto indivisível) aquele esquema de legitimação simplesmente não funciona, por não se conseguir visualizar onde se encontra, como diz a doutrina italiana, o punto de riferimento, isto é, a titularidade da situação jurídica ${ }^{150}$.
\end{abstract}

Não por outro motivo, CAPPELLETTI já apontava a necessidade de uma releitura dos institutos processuais clássicos, especialmente o da legitimação para agir como condição para uma tutela judicial efetiva aos interesses metaindividuais ${ }^{151}$. Com efeito, nas ações coletivas, a legitimidade para agir não podia permanecer nos moldes do processo civil individual, tendo sido repensada para adequar-se às necessidades e às peculiaridades da jurisdição coletiva, donde se justifica porque, nestas ações, "a idéia de legitimidade para a causa não tem nada a ver com a titularidade do direito material" ${ }^{\text {152 }}$. No mesmo sentido, MANCUSO esclarece que a noção de justa parte, nas demandas coletivas, não está na titularidade do direito, mas, sim, na capacidade ou idoneidade do portador desses interesses em representá-los adequadamente (enti esponenziali) ${ }^{153}$.

\footnotetext{
${ }^{150}$ MANCUSO, Rodolfo de Camargo. A concomitância de ações coletivas, entre si, e em face das ações individuais. In Revista dos Tribunais, ano 89, v. 782, São Paulo, dez. 2000, p. 27 (g.n.).

${ }^{151}$ CAPPELLETTI, Mauro. Vindicating the public interest through the courts. The judicial process in comparative perspective. Oxford: Clarendon Press, 1989, p. 304. Apud MANCUSO, Rodolfo de Camargo. Interesses Difusos ..., op. cit., p. 189.

${ }^{152}$ Cf. MARINONI, Guilherme e ARENHART, Sérgio Cruz. Manual do processo de conhecimento. São Paulo: Revista dos Tribunais, 2003, p. 68.

${ }^{153}$ MANCUSO, Rodolfo de Camargo. Interesses Difusos..., op. cit., p, 183.
} 
É bem verdade que, no caso da defesa do meio ambiente, por exemplo, em virtude da dispersão desse tipo de interesse por um grande ou indeterminado número de sujeitos, exsurge uma dificuldade de representação nos vários processos sociais, e não apenas no judicial, havendo uma tendência a que tais interesses permanecem sub-representados ${ }^{154}$. Em que pese essa dificuldade, é certo que, uma vez aberta a via judicial, é preciso definir quem poderá exercer a defesa desses interesses em juízo e, mais, se tal portador representará os interesses da coletividade adequadamente. A esse respeito, SALLES assinala que "esta opção quanto a quem pode exercer a defesa daqueles interesses está contida na definição da legitimidade para a iniciativa judicial, trazendo implícita uma política pública de acesso à justiça, que expressa uma escolha valorativa do legislador"155.

No Brasil, o legislador acabou distanciando-se do sistema norte-americano das class actions (de legitimação "privada" e difusa, em que a adequacy of representation é submetida a crivo/certificação judicial, em cada caso concreto) e da própria Lei da Ação Popular, para adotar, na LACP e no CDC, um critério formal e objetivo de legitimidade, entregando-a a algumas entidades, consideradas legítimas pelo só efeito da lei independentemente de sua capacidade material para desempenhar a respectiva função ${ }^{156}$.

A legitimação está prevista ope legis no artigo $5^{\circ}$ da Lei n. $7.347 / 85^{157}$, com a redação dada pela Lei n. 11.448/07:

Art. $5^{\circ}$. Têm legitimidade para propor a ação principal e a ação cautelar:

I - o Ministério Público;

II - a Defensoria Pública; ${ }^{158}$

\footnotetext{
${ }^{154}$ Cf. SALLES, Carlos Alberto de. Execução judicial de obrigação..., op. cit., p. 126 e 142.

${ }^{155}$ Idem, ibidem, p. 142.

156 A esse respeito, Alexandre Amaral GAVRONSKI defende que os entes legitimados devem buscar especialização, qualificação e organização de modo a consolidarem-se como litigantes habituais ativos e dessa condição fazerem bom uso (In Propostas para incrementar a efetividade dos instrumentos previstos na Lei n. 7.347/85 e ampliar o acesso à justiça nos direitos coletivos. In Ação Civil Pública - 20 anos da Lei 7.347/85. ROCHA, João Carlos de Carvalho, HENRIQUES F ${ }^{\circ}$, Tarcísio Humberto Parreiras, CAZETTA, Ubiratan (Coords.). Belo Horizonte: Del Rey, 2005, p. 121).

${ }^{157}$ No mesmo sentido, vide artigo 82 do Código de Defesa do Consumidor.

${ }^{158}$ A inclusão da Defensoria Pública no rol de legitimados ativos deu ensejo à propositura de Ação Direta de Inconstitucionalidade - ADI/3943, no Supremo Tribunal Federal, por parte da Associação Nacional dos Membros do Ministério Público - CONAMP, sob o argumento de que a Defensoria Pública somente pode atender aos necessitados que comprovarem, individualmente, carência financeira (artigo $5^{\circ}$, LXXIV, CF), não havendo possibilidade de atuar na defesa dos interesses difusos, coletivos ou individuais homogêneos. Referida Ação, de relatoria da Ministra Carmem Lucia, proposta em 16.08.2007, ainda não foi julgada (informação disponível em. $<$ http://www.stf.jus.br $>$. Acesso em: 27.12.2008).
} 
III - a União, os Estados, o Distrito Federal e os Municípios;

IV - a autarquia, empresa pública, fundação ou sociedade de economia mista;

$\mathrm{V}-\mathrm{a}$ associação que, concomitantemente:

a) esteja constituída há pelo menos 1 (um) ano nos termos da lei civil;

b) inclua, entre suas finalidades institucionais, a proteção ao meio ambiente, ao consumidor, à ordem econômica, à livre concorrência ou ao patrimônio artístico, estético, histórico, turístico e paisagístico ${ }^{159}$.

Tais entidades ${ }^{160}$ estão objetivamente legitimadas a defender os interesses da coletividade; vale dizer, não há um controle ope judicis, sendo a legitimidade operada ope legis. Exige-se, no entanto, que haja um mínimo de pertinência temática (e territorial) entre o legitimado ativo e o objeto da ação, bem como, no caso das associações, que tenham ao menos um ano de existência e tenham como finalidade institucional a defesa daquele bem jurídico tutelado na ação - tais requisitos deverão ser aferidos pelo juiz em cada caso concreto. Assim, por exemplo, uma associação de proteção das florestas de Araucária, sediada em Curitiba/PR, não teria legitimidade para propor ação coletiva em prol dos portadores de deficiência física, no Município de Manaus/AM.

Trata-se, como preceitua a maioria da doutrina, de legitimação concorrente $\boldsymbol{e}$ disjuntiva, de clara inspiração pluralista, no sentido de que os representantes adequados concorrem entre si para a propositura da ação, e qualquer um dos co-legitimados pode propor a ação sozinho, sem a anuência, intervenção ou autorização dos demais ${ }^{161}$.

Todavia, no que tange à natureza jurídica dessa legitimação, a doutrina diverge entre legitimação ordinária, extraordinária e autônoma. Embora não seja, como adverte BARBOSA MOREIRA, “tão relevante saber a que título se dá proteção jurisdicional aos

\footnotetext{
${ }^{159}$ Disponível em $<$ http://www.planalto.gov.br/ccivil 03/Leis/L7347orig.htm $>$. Acesso em: 27.12.2008.

${ }^{160}$ A respeito da não-inclusão de indivíduos (pessoas físicas) como legitimados ativos, vide MANCUSO, Rodolfo de Camargo. Interesses Difusos..., op. cit., p. 154 e ss., e SALLES, Carlos Alberto de. Execução judicial de obrigação..., op. cit., p. 142/151, dentre outros.

${ }^{161}$ Cf. BARBOSA MOREIRA, José Carlos. A ação popular no direito brasileiro como instrumento de tutela jurisdicional dos chamados "interesses difusos". Temas de Direito Processual, primeira série. São Paulo: Saraiva, 1977, p. 118; e LENZA, Pedro. Teoria Geral da Ação Civil Pública. São Paulo: Revista dos Tribunais, 2005, p. 178, passim.
} 
direitos superindividuais, se efetivamente se dá tal proteção"162, a doutrina majoritária - à qual nos afiliamos - entende se tratar de legitimidade extraordinária, havendo substituição processual da coletividade nas demandas coletivas. Isso porque, embora a entidade legitimada possa estar (também) em defesa de um interesse institucional próprio, o que importa é que a coletividade estará sempre e necessariamente substituída por um representante adequado, donde se conclui que, na sociedade de massa, a legitimação extraordinária deve ser a regra da tutela jurisdicional coletiva ${ }^{163}$.

Tomando por base a didática sistematização de BARBOSA MOREIRA ${ }^{164}$, pode-se afirmar que na defesa de interesses difusos ou coletivos, caracteriza-se a legitimação extraordinária, autônoma e exclusiva dos legitimados ${ }^{165}$, porque em tal hipótese a lei não permite que o substituído, individualmente, ajuíze a demanda; ao passo que, na defesa de interesses individuais homogêneos, verifica-se a caracterização da substituição processual, pois cada substituído pode, isoladamente, propor a ação ${ }^{166}$. Por seu turno, NERY e $\mathrm{NERY}^{167}$ entendem tratar-se de legitimação autônoma para a condução do processo (selbständige Prozeßfuhrüngsbefugnis) no caso dos interesses essencialmente coletivos, e de substituição processual somente no caso dos acidentalmente coletivos, posição também adotada por LEONEL ${ }^{168}$. Já SALLES faz uma distinção em se tratando de ação movida pelo Ministério Público: no caso dos interesses individuais homogêneos, trata-se de legitimação extraordinária, ao passo que, para a tutela dos difusos e coletivos, trata-se de legitimação anômala (nem ordinária nem extraordinária) ${ }^{169}$.

\footnotetext{
${ }^{162}$ BARBOSA MOREIRA, José Carlos. A ação popular..., op. cit., p. 113.

${ }^{163}$ Nesse sentido: GRINOVER (Uma nova modalidade de legitimação à ação popular. Possibilidade de conexão, continência e litispendência. In Ação Civil Pública - reminiscências e reflexões após 10 anos de aplicação. MILARÉ, Édis (Coord.). São Paulo: Revista dos Tribunais, 1995, p. 24/25), DINAMARCO (Instituições de Direito Processual Civil. São Paulo: Malheiros, 2005, v. I, p. 219), YARSHELL (Tutela jurisdicional. São Paulo: Atlas, 1998, p. 104), ZAVASCKI (Tutela de Direitos Coletivos e Tutela Coletiva de Direitos. São Paulo: Revista dos Tribunais, 2008, p. 77, 158 e 174), VIGLIAR (Tutela jurisdicional coletiva. São Paulo: Atlas, 1998, p. 153), LENZA (Teoria Geral..., op. cit., p. 191), dentre outros.

${ }_{164}$ BARBOSA MOREIRA, José Carlos. Apontamentos para um estudo sistemático da legitimação extraordinária. Direito Processual Civil (ensaios e pareceres). Rio de Janeiro: Borsoi, 1971, p. 58 e ss.

${ }^{165}$ Cf. LENZA, Pedro. Teoria ..., op. cit., p. 193.

${ }^{166}$ Nesse sentido, GRINOVER, Ada Pellegrini. Ação civil pública. Palestra proferida no Seminário Tutela dos Interesses Difusos e Coletivos - Inquérito Civil e Ação Civil Pública - Aspectos Polêmicos, realizado em 20.11.1996, na Escola Paulista do Ministério Público. Boletim Informativo ESMP, n. 3, p. 1, 1996.

${ }^{167}$ NERY JR., Nelson e NERY, Rosa Maria de Andrade. Código de processo civil..., op. cit. (nota 2 ao art. $5^{\circ}$ da Lei 7347/85).

${ }^{168}$ LEONEL, Ricardo de Barros. Manual do processo coletivo. São Paulo: Revista dos Tribunais, 2002, p. 160 , passim.

169 SALLES, Carlos Alberto de. Legitimação do Ministério Público para defesa de direitos e garantias constitucionais. Dissertação (Mestrado). 30.11.1992. Orientador: Prof. Dr. Kazuo Watanabe. São Paulo, 1992. Faculdade de Direito, Universidade de São Paulo.
} 
No ponto, vale lembrar que, embora a LACP e o CDC tenham excluído a legitimação de indivíduos, pessoas físicas, para a propositura da ação coletiva, estes continuam sendo legitimados expressamente para a propositura de Ação Popular, que também se revela meio adequado para fazer atuar a função jurisdicional do Estado em prol do interesse público, a teor da ressalva constante do art. $1^{\circ}$ da Lei n. 7.347/85 e do disposto no art. $5^{\circ}$, LXXIII, da Constituição Federal. Nesse caso, a legitimação para agir é ordinária, por agir o indivíduo em defesa de um direito que (também) lhe pertence ${ }^{170}$.

Um último aspecto relacionado à legitimidade para agir merece ser citado - nos estreitos limites do presente trabalho -, qual seja, a possibilidade de os legitimados agirem em conjunto, somando esforços, em litisconsórcio facultativo. Isso não só é possível como é, até, recomendável, no sentido de "levar ao Judiciário, com maior celeridade e transparência possível, esses interesses difusos que até agora vagavam, acéfalos e ignorados, pelas sombrias regiões do "limbo-jurídico""171. A possibilidade de litisconsórcio ativo terá relevância no exame da relação entre demandas, conforme se verá mais adiante.

Assim, respeitado o foco do presente trabalho, i.e., a relação entre demandas coletivas com ênfase no dano ambiental, o quanto até aqui exposto era o que precisava ser dito acerca da legitimidade para agir, especialmente para fundamentar que, em se tratando de substituição processual, a identidade física dos legitimados ativos não tem relevância, mas, sim, a função que exercem no processo.

\section{II.5.2. Indivisibilidade do objeto}

Outra característica marcante dos interesses transindividuais - em especial, os difusos - é a indivisibilidade do objeto.

\footnotetext{
${ }^{170}$ Nesse sentido, SILVA, José Afonso da. Ação Popular Constitucional. São Paulo: Revista dos Tribunais, 1978, p. 195.

${ }^{171}$ MANCUSO, Rodolfo de Camargo. Interesses Difusos..., op. cit., p. 257.
} 
Para compreender a exata noção do que vem a ser objeto indivisivel, socorremo-nos da lição de BARBOSA MOREIRA: "é impossível satisfazer o direito ou interesse de um dos membros da coletividade, e vice-versa: não é possível rejeitar a proteção sem que essa rejeição afete necessariamente a coletividade como tal" ${ }^{\text {172 }}$. Como decorrência, a solução será, por natureza, unitária, incindivel: ou todos serão satisfeitos ou nenhum será satisfeito. Dito de outro modo, a fruição do bem por um indivíduo implica a possibilidade de fruição por todos.

Nesse sentido, LENZA ressalta que, no tocante aos interesses difusos, a indivisibilidade é ampla e absoluta; já em relação aos interesses coletivos, a indivisibilidade dos bens é percebida no âmbito interno, dentre os membros do grupo, categoria ou classe de pessoas; ao passo que os interesses individuais homogêneos caracterizam-se por sua divisibilidade plena ${ }^{173}$.

No caso dos interesses difusos, portanto, a demanda deve ser formulada com o mote de beneficiar uniformemente a todos que se encontrem na mesma situação, dada a indivisibilidade do objeto. Essa característica é crucial para o exame da relação entre demandas coletivas. Isso porque o objeto indivisível (não-passível de fracionamento em múltiplas ações) reclama tratamento unitário e solução uniforme, de tal forma que a virtual prolação de comandos de conteúdo diverso engendrará contradição que não se conterá apenas no plano lógico, mas desbordará para o plano prático.

A condição de indivisibilidade tem íntima relação com os efeitos erga omnes da coisa julgada. Em última análise, esta é decorrência lógica daquela; afinal, se o objeto é insuscetível de divisão em quotas, é sinal que a decisão "atingirá necessariamente a esfera jurídica de todos os membros da coletividade ou do grupo, que, em última análise, são, em conjunto, os únicos titulares do direito em litígio"174.

\footnotetext{
${ }^{172}$ BARBOSA MOREIRA, José Carlos. Ações coletivas na Constituição..., op. cit., p. 188. No mesmo sentido, WATANABE salienta que "o bem jurídico (...) é indivisível no sentido de que basta uma única ofensa para que todos os consumidores sejam atingidos e também no sentido de que a satisfação de um deles, pela cessação da publicidade ilegal, beneficia contemporaneamente a todos eles" (In Comentários ao artigo 81, CDC. Código Brasileiro de Defesa..., op. cit., p. 802).

${ }^{173}$ LENZA, Pedro. Teoria..., op. cit., p. 76. Ainda, sobre o tema, vide SALLES, Carlos Alberto de. Execução Judicial em Matéria Ambiental. São Paulo: Revista dos Tribunais, 1998, p. 67/69.

${ }^{174}$ GIDI, Antonio. Coisa julgada..., op. cit., p. 58/59.
} 


\section{II.5.3. Coisa julgada}

O terceiro e último ponto nevrálgico das demandas coletivas que merece ser tratado, ainda que sucintamente, diz respeito aos limites subjetivos da coisa julgada.

Como visto no Capítulo I, a coisa julgada corresponde à imutabilidade do comando da sentença e, dessa forma, configura impedimento à rediscussão da mesma ação, já julgada definitivamente, em processo autônomo. No Direito Processual clássico, os limites objetivos da coisa julgada estão delineados nos artigos 468, 469, 470 e 471 do CPC, e os limites subjetivos, no artigo 472 do referido Código, que assim dispõe: "A sentença faz coisa julgada às partes entre as quais é dada, não beneficiando, nem prejudicando terceiros". A regra do res inter alios iudicata aliis nec nocet nec prodest obedece ao corolário do devido processo legal, em especial, o contraditório e a ampla defesa.

Todavia, já em 1943, LIEBMAN vislumbrava possíveis exceções à regra de que a autoridade da coisa julgada limita-se às partes, fazendo menção a uma "tendência socializadora e antiindividualística do direito" ${ }^{175}$. É o que ocorre, nos dias de hoje, com a jurisdição coletiva, em que os estreitos limites da coisa julgada, típicos da esfera intersubjetiva, não se mostram perfeitamente adequados; afinal, que sentido faria tratar molecularmente um conflito, se o resultado do processo não pudesse atingir a todos os interessados?

Assim, dadas as peculiaridades das demandas coletivas, em especial, a legitimidade extraordinária e a indivisibilidade do objeto, a coisa julgada coletiva foi sensivelmente alterada, ampliando-se os limites da imutabilidade do comando do julgado, de forma a estender seus efeitos a todos os indivíduos que se encontrem na situação disciplinada pela decisão. É o que se convencionou chamar de coisa julgada erga omnes.

\footnotetext{
${ }^{175}$ LIEBMAN, Enrico Tullio. Eficácia e Autoridade da Sentença e Outros Escritos Sobre a Coisa Julgada (atualizado por GRINOVER, Ada Pellegrini). Rio de Janeiro: Forense, 2007. Apud GIDI, Antonio. Coisa julgada..., op. cit., p. 13.
} 
A alteração é mais do que justificada, pois, como salienta GRINOVER, a coisa julgada erga omnes é uma exigência do próprio tratamento coletivo. Com efeito, "de nada serviria tratar esses bens e interesses coletivamente, se não houvesse uma qualidade de imutabilidade da sentença que se projetasse com relação a todas aquelas pessoas que podem ser beneficiadas por esta sentença"176.

Confira-se, a respeito, a redação dos artigos 103 e 104 do CDC, in verbis:

Art. 103. Nas ações coletivas de que trata este código, a sentença fará coisa julgada:

I - erga omnes, exceto se o pedido for julgado improcedente por insuficiência de provas, hipótese em que qualquer legitimado poderá intentar outra ação, com idêntico fundamento valendo-se de nova prova, na hipótese do inciso I do parágrafo único do art. 81;

II - ultra partes, mas limitadamente ao grupo, categoria ou classe, salvo improcedência por insuficiência de provas, nos termos do inciso anterior, quando se tratar da hipótese prevista no inciso II do parágrafo único do art. 81;

III - erga omnes, apenas no caso de procedência do pedido, para beneficiar todas as vítimas e seus sucessores, na hipótese do inciso III do parágrafo único do art. 81.

$\S 1^{\circ}$ Os efeitos da coisa julgada previstos nos incisos I e II não prejudicarão interesses e direitos individuais dos integrantes da coletividade, do grupo, categoria ou classe.

$\S 2^{\circ} \mathrm{Na}$ hipótese prevista no inciso III, em caso de improcedência do pedido, os interessados que não tiverem intervindo no processo como litisconsortes poderão propor ação de indenização a título individual.

$\S 3^{\circ}$ Os efeitos da coisa julgada de que cuida o art. 16 , combinado com o art. 13 da Lei n. 7.347, de 24 de julho de 1985, não prejudicarão as ações de indenização por danos pessoalmente sofridos, propostas individualmente ou na forma prevista neste código, mas, se procedente o pedido, beneficiarão as vítimas e seus sucessores, que poderão proceder à liquidação e à execução, nos termos dos arts. 96 a 99.

$\S 4^{\circ}$ Aplica-se o disposto no parágrafo anterior à sentença penal condenatória.

${ }^{176}$ GRINOVER, Ada Pellegrini. A coisa julgada perante a Constituição..., op.cit., p. 148/149. 
Art. 104. As ações coletivas, previstas nos incisos I e II e do parágrafo único do art. 81, não induzem litispendência para as ações individuais, mas os efeitos da coisa julgada erga omnes ou ultra partes a que aludem os incisos II e III do artigo anterior não beneficiarão os autores das ações individuais, se não for requerida sua suspensão ${ }^{177}$ no prazo de trinta dias, a contar da ciência nos autos do ajuizamento da ação coletiva.

Como se vê, a coisa julgada sofre uma ou outra variação, conforme o feixe de interesse metaindividual tutelado: difuso, coletivo (stricto sensu) ou individual homogêneo.

\section{II.5.3.1. Coisa julgada nos direitos difusos}

Inspiradas pela Lei da Ação Popular, as Leis n. 7.347/85 e n. 8.078/90 dispuseram que, para os direitos transindividuais de natureza indivisível, cujos titulares liguem-se por circunstâncias de fato, o alcance subjetivo da coisa julgada será erga omnes, exceto se o pedido for julgado improcedente por falta de provas (art. 103, I, CDC). Vale dizer: a decisão de mérito vinculará toda a coletividade, quer se trate de sentença de procedência ou de improcedência, impedindo a repropositura de nova ação coletiva (rectius $=$ mesma ação). Tal regra, no entanto, comporta duas exceções: (i) a ação coletiva poderá ser reproposta se o pedido tiver sido julgado improcedente por insuficiência de prova, 'hipótese em que qualquer legitimado poderá intentar outra ação com idêntico fundamento, valendo-se de nova prova'; e (ii) a coisa julgada coletiva não prejudicará interesses e direitos individuais, ficando resguardado o direito de ação de cada indivíduo.

A variação da imutabilidade do julgado de acordo com o resultado do processo é o que se denomina coisa julgada secundum eventum litis.

\footnotetext{
${ }^{177}$ Atualmente, a doutrina majoritária defende que a suspensão da ação individual não está sujeita aos limites temporais do CPC (art. 265, $\S 5^{\circ}=1$ ano), podendo perdurar até o trânsito em julgado da ação coletiva. Esta é a linha seguida pelo ANTEPROJETO DE CÓDIGO BRASILEIRO DE PROCESSOS COLETIVOS DA USP (art. $6^{\circ}, \S 2^{\circ}$ ) e pela PROPOSTA DO MINISTÉRIO DA JUSTIÇA/SECRETARIA DE REFORMA DO JUDICIÁRIO (art. $8^{\circ}, \S^{\circ}$ ).
} 
Quanto à primeira exceção, tem-se que, no caso da improcedência por insuficiência de prova, nova ação coletiva poderá ser intentada por qualquer legitimado (inclusive pelo mesmo autor da primeira demanda ${ }^{178}$ ), desde que apresente "prova nova", assim entendida aquela não apresentada na primeira demanda (não necessariamente ulterior) ${ }^{179}$.

No que se refere à segunda exceção, tem-se que: de um lado, a improcedência da ação coletiva não retira a possibilidade de os indivíduos eventualmente prejudicados moverem suas próprias demandas (art. 103, $\S 1^{\circ}, \mathrm{CDC}$ ); e, de outro lado, a procedência da ação coletiva beneficia os indivíduos prejudicados, os quais poderão liquidar diretamente a sentença coletiva para ressarcimento dos danos individualmente sofridos (art. 103, §3 $\mathrm{CDC})^{180}$ - a sentença coletiva estabelece o dever genérico de indenizar (an debeatur), restando apenas a fixação individual do quantum debeatur. Só não poderão beneficiar-se da sentença de procedência da ação coletiva os indivíduos que, tendo proposto ação individual, não requererem a suspensão de seus processos (art. 104, in fine, CDC).

\section{II.5.3.2. Coisa julgada nos direitos coletivos}

Quando se tratar de tutela de interesses coletivos em sentido estrito, a coisa julgada operará efeitos ultra partes, limitada ao grupo, categoria ou classe de pessoas, as quais estão ligadas ente si ou com a parte contrária por uma relação jurídica-base (art. 103, II, CDC).

\footnotetext{
${ }^{178}$ Nesse sentido: ARRUDA ALVIM. Código de Defesa do Consumidor Comentado. São Paulo: Revista dos Tribunais, 1995, p. 461; ARRUDA ALVIM, Eduardo. Coisa julgada a litispendência no Anteprojeto de Código Brasileiro de Processos Coletivos. In Direito Processual Coletivo e o Anteprojeto de Código Brasileiro de Processos Coletivos. GRINOVER, Ada Pellegrini, MENDES, Aluisio Gonçalves de Castro e WATANABE, Kazuo (Coords.). São Paulo: Revista dos Tribunais, 2007, p. 181, dentre outros.

179 ARRUDA ALVIM. Notas sobre a coisa julgada coletiva. Revista da Associação dos Magistrados Brasileiros - Cidadania e Justiça 9, p. 88.

${ }^{180}$ Nesse sentido, ARRUDA ALVIM, Eduardo salienta que "o indivíduo cuja situação específica seja afetada por esse mesmo evento poderá, diretamente, promover a liquidação de seu dano" (In Coisa julgada ..., op. cit., p. 179).
} 
A decisão de mérito vinculará todos os integrantes do grupo, quer se trate de sentença de procedência ou de improcedência, impedindo a repropositura de nova ação coletiva (rectius = mesma ação), exceto se o pedido for julgado improcedente por falta de provas. Exemplo típico advém das relações de consumo: em ação coletiva na qual se discuta a abusividade de cláusula contratual de determinada empresa de plano de saúde, todos os consumidores integrantes daquele grupo (todos aqueles que assinaram o contrato com a seguradora) serão atingidos pela decisão, seja ela favorável ou desfavorável. Aqui, também, a coisa julgada é secundum eventum litis, pois varia conforme o resultado do processo (se a improcedência for por insuficiência de provas, admite-se a repropositura da ação coletiva, por qualquer legitimado ativo).

Igualmente, nada obsta que os indivíduos eventualmente prejudicados proponham suas próprias demandas para a defesa de seus interesses (art. 103, $\S 1^{\circ}, \mathrm{CDC}$ ), sendo certo, também, que a procedência da ação coletiva beneficia os indivíduos prejudicados, os quais poderão liquidar diretamente a sentença coletiva para ressarcimento dos danos individualmente sofridos ( $\operatorname{art} 103, \S 3^{\circ}, \mathrm{CDC}$ ). Só não poderão beneficiar-se da sentença de procedência da ação coletiva os indivíduos que, tendo proposto ação individual, não requererem a suspensão de seus processos (art. 104, in fine, CDC).

\section{II.5.3.3. Coisa julgada nos direitos individuais homogêneos}

No caso das ações coletivas para tutela de interesses individuais homogêneos, o regime da coisa julgada opera-se de forma um pouco mais complexa: a coisa julgada será erga omnes apenas no caso de procedência do pedido, sendo, por isso, chamada de coisa julgada in utilibus

Se a ação for julgada procedente, todos os indivíduos serão beneficiados pela coisa julgada, isto é, a coisa julgada terá efeitos erga omnes - (art. 103. III, CDC). Nesta hipótese, os indivíduos poderão promover a liquidação da sentença coletiva, demonstrando que sua situação enquadra-se na condição genericamente descrita ${ }^{181}$. Tal regra, no entanto, comporta uma exceção - em uma interpretação analógica e teleológica do art. 104, in fine,

${ }^{181}$ ARRUDA ALVIM. Notas sobre a coisa julgada..., op. cit.. 
$\mathrm{CDC}^{182}$ : não poderão beneficiar-se da sentença de procedência da ação coletiva os indivíduos que, tendo proposto ação individual, não requererem a suspensão de seus processos.

De outro lado, se a ação for julgada improcedente, a sentença não prejudicará interesses e direitos individuais ${ }^{183}$, sendo facultado aos indivíduos intentarem sua própria ação (art. 103, $\S 2^{\circ}, \mathrm{CDC}$ ). Aqui, também, a regra comporta uma exceção: não poderão demandar individualmente as pessoas que tiverem ingressado na ação coletiva como assistentes $^{184}$.

Ressalvados os direitos individuais, é certo que, no plano coletivo, a sentença de improcedência inviabilizará a propositura de nova demanda por qualquer dos legitimados ativos, seja a improcedência pelo mérito ou por insuficiência de prova.

A bem ver, portanto, nos direitos individuais homogêneos, a coisa julgada opera efeitos erga omnes apenas para beneficiar os indivíduos. A extensão in utilibus da coisa julgada deve-se a uma opção do legislador brasileiro, de não adotar a técnica da fair notice e o sistema do opt in ou opt out, típico das class actions norte- americanas. É bem verdade que a doutrina não é unânime quanto ao acerto do legislador pátrio em instituir o sistema da extensão in utilibus da coisa julgada para os interesses individuais homogêneos.

\footnotetext{
${ }^{182}$ A doutrina, de forma majoritária, reconhece que houve um erro de remissão no artigo 104 do CDC, ao se referir apenas aos incisos I e II e do parágrafo único do art. 81 (interesses difusos e coletivos), deixando de mencionar o seu inciso III (interesses individuais homogêneos). Tal questão será analisada com mais vagar no Capítulo III, item III.7.

${ }^{183}$ Vale mencionar que o MINISTÉRIO DA JUSTIÇA/SECRETARIA DE REFORMA DO JUDICIÁRIO, em sua proposta de alteração da Lei da Ação Civil Pública, altera essa regra em dois dispositivos, a saber: artigo $8^{\circ}, \S 6^{\circ}$ ("Transitada em julgado a sentença coletiva de improcedência do pedido que não seja fundada na insuficiência de prova, as ações individuais serão extintas"); e artigo 29, §2 ("Os efeitos da coisa julgada coletiva na tutela de direitos individuais homogêneos não prejudicarão interesses e direitos individuais dos integrantes da coletividade, do grupo, categoria ou classe, que poderão propor ações individuais em sua tutela, desde que o pedido no processo coletivo tenha sido julgado improcedente por insuficiência de prova").

${ }^{184}$ Aqui, também, o ANTEPROJETO DA USP altera a regra atual, ao dispor em seu artigo $6^{\circ}, \S 1^{\circ}$ que: "Cabe ao demandado informar o juízo da ação individual sobre a existência de demanda coletiva que verse sobre idêntico bem jurídico, sob pena de, não o fazendo, o autor individual beneficiar-se da coisa julgada coletiva mesmo no caso de a ação individual ser rejeitada"; no mesmo sentido é a proposta do Ministério da Justiça/Secretaria de Reforma do Judiciário (artigo $8^{\circ}, \S 2^{\circ}$ ).
} 
Há quem entenda que essa sistemática torna o processo pouco eficaz no plano concreto, desatendendo ao objetivo de maximização dos resultados ${ }^{185}$. Isso porque, no caso de improcedência, inúmeras demandas individuais poderão ser propostas, o que tornaria o processo coletivo inútil. Pior: as ações individuais seriam distribuídas livremente, podendo gerar resultados antagônicos (pois nenhum juiz ficará vinculado ao julgamento de improcedência da ação coletiva), dando ensejo à situação denominada por CAMBI de "jurisprudência lotérica" "186. Tal circunstância pode ser entendida como uma afronta ao princípio da isonomia, não bastasse a diferença de tratamento entre as partes do processo (o julgamento a favor da coletividade é válido para fins de imutabilidade, ao passo que o julgamento a favor do réu não impede a rediscussão da matéria em inúmeras ações individuais). Daí porque os doutrinadores filiados a essa corrente propõem a adoção do sistema das class actions norte-americanas, com notificação dos interessados para, em querendo, optarem por não se sujeitarem à coisa julgada (right to opt out), ou, do contrário, sujeitarem-se à coisa julgada seja ela favorável ou não (whether or not favorable). Afinal, se o autor da ação coletiva representou adequadamente os interesses da coletividade, grupo, categoria ou classe, com zelo, capacidade, empenho, idoneidade, não há porque se alegar ofensa ao contraditório e à ampla defesa dos substituídos.

Em que pesem esses argumentos, outros tantos doutrinadores de escol defendem exatamente o contrário: o sistema da extensão secumdum eventum litis e in utilibus é condizente com as características e necessidades da jurisdição coletiva, além de observar o princípio da inafastabilidade da jurisdição e da inviabilidade de notificação de todos os interessados ${ }^{187}$. Além da custosa notificação (de difícil execução em um país de dimensões continentais e de comunicação precária como o nosso), o sistema norte-americano ainda

\footnotetext{
${ }^{185}$ Nesse sentido: CRUZ E TUCCI, José Rogério (Código do Consumidor e Processo civil - Aspectos polêmicos. Revista dos Tribunais, n. 671, p. 35/39, São Paulo: Revista dos Tribunais, set. 1991); LIMA, Maria Rosynete Oliveira (Devido processo legal. Porto Alegre: Fabris, 1999, p. 271/272); LEAL, Márcio Flávio Mafra (Ações coletivas: história, teoria e prática. Porto Alegre Fabris, 1998, p. 210); MENDES, Aluísio Gonçalves de Castro (As ações coletivas no direito comparado e nacional. São Paulo: Revista dos Tribunais, 2002, v. 4, p. 261/262); DINAMARCO, Pedro Silva (Ação civil Pública. São Paulo: Saraiva, 2001, p.105/106); MATTOS, Luiz Norton Baptista de (A litispendência e a coisa julgada nas ações coletivas segundo o Código de Defesa do Consumidor e os anteprojetos do Código Brasileiro de Processos Coletivos. In Direito Processual Coletivo e o Anteprojeto de Código Brasileiro de Processos Coletivos. GRINOVER, Ada Pellegrini, MENDES, Aluisio Gonçalves de Castro e WATANABE, Kazuo (Coords.). São Paulo: Revista dos Tribunais, 2007, p. 207).

${ }^{186}$ CAMBI, Eduardo Augusto Salomão. Jurisprudência lotérica. Revista dos Tribunais. São Paulo: Revista dos Tribunais, v. 786, p. 108/128, 2001.

${ }^{187}$ Nesse sentido: LENZA, Pedro. Teoria ..., op. cit., p. 269; ROCHA, Ibraim. Litisconsórcio, efeitos da sentença e coisa julgada nas ações coletivas. Rio de Janeiro: Forense, 2002, p 223; LEONEL, Ricardo de Barros. Manual..., op. cit., p 265; GIDI, Antônio. Coisa julgada..., op. cit., p 97, dentre outros.
} 
traz a 'desvantagem' da fase de certificação, que pode dar ensejo a incidentes processuais desnecessários $^{188}$, se comparado ao regime da representatividade ope legis. Embora não seja um sistema perfeito, entendemos que o sistema adotado pela LACP e pelo CDC ainda apresenta mais vantagens do que desvantagens.

\section{II.6. A Lei n. 9.494/97}

Um dos pontos que não poderia deixar de ser examinado, como premissa para o estudo da relação entre demandas coletivas, diz respeito à alteração do artigo 16 da LACP, pela Lei n. 9.494/97, que limitou o alcance da autoridade da coisa julgada ${ }^{189}$ à competência $^{190}$ territorial do juízo prolator da sentença, gerando graves conseqüências no exercício da jurisdição coletiva. A doutrina é unânime em rechaçar as alterações introduzidas por essa lei, por entender que representam verdadeiro retrocesso. A jurisprudência, por sua vez, trata da questão de maneira bastante oscilante, ora aplicando a referida Lei, ora rejeitando-a.

\section{II.6.1. Evolução histórica}

O artigo 16 da Lei n. 7.347/85, em sua redação original, reproduzia o artigo 18 da Lei da Ação Popular, e fixava o alcance erga omnes da autoridade da coisa julgada, salvo na hipótese de a ação ser julgada improcedente por insuficiência de provas.

Nos primeiros anos de aplicação da Lei da Ação Civil Pública, os tribunais tentaram limitar os efeitos erga omnes da coisa julgada, confundindo-os, por vezes, com critérios de competência. A doutrina cita como exemplos o caso da proibição da mistura de

\footnotetext{
${ }^{188}$ ALMEIDA, Gregório Assagra de salienta que "Não é razoável que [se] estabeleça muitos requisitos específicos de admissibilidade processual, pois isso poderá burocratizar o sistema com o surgimento de incidentes indesejados" (In Direito material coletivo - superação da summa divisio direito público e direito privado por uma nova summa divisio constitucionalizada. Belo Horizonte: Del Rey, 2008, p. 590).

${ }_{189}$ A coisa julgada é a qualidade de que se reveste a sentença, consistente na sua imutabilidade, seja no mesmo processo (coisa julgada formal), seja fora dele (coisa julgada material, desde que haja julgamento de mérito).

${ }^{190}$ Segundo LIEBMAN, a competência como "a quantidade de jurisdição cujo exercício é atribuído a cada órgão ou grupo de órgãos" (cf. CINTRA, GRINOVER e DINAMARCO. Teoria Geral do Processo. São Paulo: Malheiros, 2005, p. 237).
} 
metanol ao álcool para venda ao consumidor, e o caso do recebimento da diferença de $147 \%$ para aposentados e pensionistas.

Em 1990, o Código de Defesa do Consumidor disciplinou, de forma mais completa, os limites subjetivos da autoridade da coisa julgada nas ações coletivas. Alguns doutrinadores chegam a dizer que, "após o advento da Lei n. 8.078/90, o artigo 16 da Lei n. 7.347/85 perdera, inquestionavelmente, a sua atualidade"191. Em síntese, o artigo 103 do CDC dispõe que a sentença fará coisa julgada: (i) erga omnes, salvo se a ação for julgada improcedente por insuficiência de provas, quando se tratar de interesses difusos; (ii) ultra partes, salvo se a ação for julgada improcedente por insuficiência de provas, quando se tratar de interesses coletivos em sentido estrito; e (iii) erga omnes, apenas quando a demanda for julgada procedente (in utilibus), quando se tratar de interesses individuais homogêneos.

Esta disciplina mais bem elaborada do CDC fez com que, aos poucos, os tribunais passassem a reconhecer o "caráter regional e nacional das decisões proferidas nas ações coletivas" $" 192$, tendo a jurisprudência se solidificado "no sentido de a coisa julgada ultra partes ou erga omnes transcender o âmbito da competência territorial, para realmente assumir dimensão regional ou nacional"193.

Bom exemplo desse novo posicionamento jurisprudencial é o caso da privatização da Telebrás, que foi objeto de várias ações coletivas, de abrangência nacional, tendo o Superior Tribunal de Justiça decidido pela reunião dos feitos, de acordo com o critério da prevenção.

Mas, conforme a jurisprudência foi reconhecendo a eficácia erga omnes e a abrangência nacional das decisões proferidas em ações civis públicas, o Executivo Federal, por razões egoístas, passou a se preocupar com o avanço legislativo da LACP e do CDC, o que o levou a editar a Medida Provisória 1.570/97, na tentativa de limitar o alcance da autoridade da coisa julgada nas ações coletivas.

\footnotetext{
${ }^{191}$ VIGLIAR, José Marcelo Menezes. A Lei 9.494, de 10 de setembro de 1997, e a nova disciplina da coisa julgada nas ações coletivas: inconstitucionalidade. Revista dos Tribunais, 745, nov. 1997, ano 86, p. 69.

${ }_{192}$ LENZA, Pedro. Teoria..., op. cit., p. 274.

${ }^{193}$ GRINOVER, Ada Pellegrini et alii. Código Brasileiro de Defesa..., op. cit., p. 917.
} 


\section{II.6.2. Involução histórica}

A Medida Provisória 1.570/97, posteriormente convertida na Lei n. 9.494/97, alterou o artigo 16 da LACP, instituindo uma nova disciplina para os limites subjetivos da coisa julgada nas ações coletivas.

Com a alteração legislativa, a nova redação do artigo 16 da LACP passou a ser a seguinte: “A sentença civil fará coisa julgada erga omnes, nos limites da competência territorial do órgão prolator, exceto se o pedido for julgado improcedente por insuficiência de provas, hipótese em que qualquer outro legitimado poderá intentar outra ação com idêntico fundamento, valendo-se de nova prova" (g.n.).

Referida lei representa verdadeira involução histórica, indo na contramão de todas as flexibilizações do processo civil moderno voltadas à defesa dos direitos metaindividuais. Afinal, limitar o alcance da autoridade da coisa julgada à competência territorial do juízo prolator da sentença significa, em última análise, multiplicar demandas, com a possibilidade concreta de haver decisões conflitantes para situações de fato idênticas - o que objetiva, ao máximo, evitar, conforme se verá a seguir. Tal situação, decorrente da aplicação cega da Lei n. 9.494/97, contraria o próprio espírito do processo civil coletivo, pois, como se sabe,

\footnotetext{
O objetivo das ações coletivas (...) foi trazer maior celeridade ao processo, evitando o conflito de decisões e sua multiplicação, fenômenos responsáveis pelo assoberbamento do Judiciário. Outra grande valia do processo coletivo reside na capacidade de assegurar o acesso à Justiça de interesses metaindividuais, muitos deles marginalizados quando individualmente considerados ${ }^{194}$.
}

Não bastasse a má intenção do legislador de 1997, diz-se, também, que este pecou pela incompetência, na medida em que alterou apenas o artigo 16 da LACP, deixando intacto o artigo 103 do $\mathrm{CDC}$, que dispôs, posteriormente e de maneira mais completa, sobre o mesmo assunto. Aludido artigo 103, combinado com o artigo 93 do CDC, que fixa

${ }^{194}$ LENZA, Pedro. Teoria..., op. cit., p. 277. 
regras de competência, tem gerado conflitos práticos intransponíveis, que felizmente põem em xeque a própria eficácia da limitação introduzida pela Lei n. 9.494/97.

\section{II.6.3. Disciplina da competência}

Para melhor compreensão do tema proposto, notadamente no que se refere à gravidade das implicações que a questão gera, vale fazer uma breve análise das regras de fixação de competência nas ações coletivas.

$\mathrm{O}$ artigo $2^{\circ}$ da LACP elegeu o local do dano como foro competente para o julgamento das ações civis públicas, dispondo o legislador que tal competência é absoluta, embora territorial ${ }^{195}$. No regime da LACP, portanto, um dano que atingisse diversas comarcas simultaneamente (por exemplo, a contaminação de um rio que banha diversos municípios) tornaria todas elas igualmente competentes para julgar a causa, aplicando-selhes o critério da prevenção.

Por sua vez, o Código de Defesa do Consumidor tratou da matéria de forma distinta, definindo a competência para as ações coletivas segundo a abrangência do dano. Nos termos do artigo 93 do CDC, o foro competente para julgar as ações coletivas varia conforme se trate de dano local, regional ou nacional. O inciso I do artigo 93 reproduz a regra da LACP (local do dano) para os casos de dano de âmbito local, ou seja, aquele adstrito a uma única comarca. Já o inciso II do artigo 93 inovou em relação à LACP, tornando competente o foro da Capital do Estado ou do Distrito Federal para os danos de âmbito nacional ou regional.

Quanto à distribuição da competência entre a capital dos Estados e o Distrito Federal, nos casos de danos regionais e nacionais, GRINOVER vislumbra quatro situações diferentes: quando o dano for local, a competência será da comarca onde ocorreu o dano; quando o dano atingir duas comarcas, a competência será concorrente, adotando-se o critério da prevenção; quando o dano for regional, o foro competente será o da capital do

${ }^{195}$ Sobre o fato de o artigo $2^{\circ}$ da LACP ter instituído uma competência territorial absoluta e não uma competência funcional, vide BARBOSA MOREIRA, José Carlos. A expressão 'competência funcional' no art. $2^{\circ}$ da Lei da Ação Civil Pública. Revista Forense, v. 380, ano 101. Rio de Janeiro: Forense, p. 179/187, jul.-ago. 2005. 
Estado ou o do Distrito Federal; e, por fim, quando o dano for nacional, a competência será sempre do Distrito Federal ${ }^{196}$.

MILARÉ, por sua vez, entende que a regra do inciso II do artigo 93 do CDC carece de complementação, uma vez que não existe, ainda hoje, definição legal de dano regional $^{197}$. A partir de quantas comarcas considera-se que o dano é regional? A partir de quantos Estados o dano deixa de ser regional e passa a ser nacional? A ausência desses critérios, na visão do autor, leva à inaplicabilidade do dispositivo. Para o autor, o dano que ultrapassar os limites territoriais de uma comarca ensejará sempre competência concorrente, a ser definida pelo critério da prevenção, ainda que esse dano atinja mais de um Estado (por exemplo, a contaminação de um rio que divide os Estados de Minas Gerais e São Paulo torna igualmente competentes as comarcas mineiras e paulistas atingidas pelo dano). Somente na hipótese de o dano atingir todo o território nacional, a competência será do Distrito Federal.

Por seu turno, MAZZILLI entende, como GRINOVER, que o dano regional é de competência da capital do Estado ou do Distrito Federal. Já com relação ao dano nacional, aquele autor discorda desta, por entender que também na hipótese de dano nacional a competência será concorrente entre a capital do Estado ou o Distrito Federal, a critério do legitimado ativo, "para mais cômoda defesa dos interesses transindividuais lesados e mais eficaz acesso à Justiça" 198 .

Com vistas a sanar as dúvidas hoje existentes, o ANTEProjeto DE Código BRASILEIRO DE Processos Coletivos DA USP ${ }^{199}$ propõe, em seu artigo 20, uma definição de dano regional, nos seguintes termos:

Art. 20. É absolutamente competente para a causa o foro:

I - do lugar onde ocorreu ou deva ocorrer o dano, quando de âmbito local;

\footnotetext{
${ }^{196}$ GRINOVER, Ada Pellegrini. Código Brasileiro de Defesa..., op. cit., p. 878.

${ }^{197}$ MILARÉ, Édis. Direito ..., op. cit., p. 1.026.

198 MAZZILLI, Hugo Nigro. A defesa dos interesses difusos em juizo: meio ambiente, consumidor, patrimônio cultural, patrimônio público e outros interesses. São Paulo: Saraiva, 2005, p. 252, passim.

${ }_{199}$ Texto disponibilizado pelos Prof. Ada Pellegrini GRINOVER, Kazuo WATANABE e Carlos Alberto de SALLES, na disciplina 'Processos Coletivos II', oferecida no Programa de Pós-Graduação stricto sensu da Faculdade de Direito da Universidade de São Paulo (USP), no segundo semestre de 2006.
} 
II - de qualquer das comarcas ou sub-seções judiciárias, quando o dano de âmbito regional compreender até 3 (três) delas, aplicando-se no caso as regras de prevenção;

III - da Capital do Estado, para os danos de âmbito regional, compreendendo 4 (quatro) ou mais comarcas ou sub-seções judiciárias; IV - de uma das Capitais do Estado, quando os danos de âmbito interestadual compreenderem até 3 (três) Estados, aplicando-se no caso as regras de prevenção;

V- do Distrito Federal, para os danos de âmbito interestadual que compreendam mais de 3 (três) Estados, ou de âmbito nacional.

Por seu turno, o MinistéRIO DA JUSTIÇA/SECRETARIA DE REFORMA DO JUdiCIÁRIO traz a seguinte proposta (ainda em fase de discussão) ${ }^{200}$ :

Art. $6^{\circ}$. É competente para a causa o foro, sem prejuízo da regra da prevenção:

(...)

II - de qualquer das comarcas ou subseção judiciária, quando o dano ou ato ilícito for de âmbito interestadual ou regional, assim entendido o que abrange até 5 (cinco) daquelas ou uma desta;

III - de uma das Capitais dos Estados afetados, quando o dano ou ato ilícito for de âmbito interestadual ou regional, assim entendido o que abrange 6 (seis) ou mais comarcas, 2 (duas) ou mais subsecções judiciárias.

Como se vê, e ficará mais claro a seguir, as alterações promovidas numa penada pelo Executivo, no uso de excepcional e questionável poder legislativo, foram introduzidas no sistema jurídico sem o devido sopesar das respectivas conseqüências, imprudência esta não evitada pelo Poder Legislativo.

\footnotetext{
${ }^{200}$ Texto disponibilizado pela Escola de Magistrados da Justiça Federal da $3^{\text {a }}$ Região - EMAG, por ocasião do evento "Sistema Único Coletivo - Proposta de Alteração da Lei da Ação Civil Pública", realizado no Tribunal Regional Federal da $3^{\text {a }}$ Região, em 17.11.2008, em São Paulo/SP.
} 


\section{II.6.4. A inoperância da Lei n. 9.494/97 nas ações ambientais}

Pois bem. Vistas, em breves linhas, as disciplinas da coisa julgada (artigo 103 do CDC) e da competência (artigo 93 do CDC) nas ações coletivas, vale fazer uma breve análise dos efeitos práticos da alteração introduzida pela Lei n. 9.494/97. Como dito acima, a doutrina é unânime em rechaçar tais alterações.

O primeiro argumento utilizado pela doutrina para afastar a incidência da referida lei consiste na própria natureza dos interesses difusos e coletivos. O que a Lei n. 9.494/97 quis ardilosamente limitar é incompatível com a própria natureza dos interesses coletivos, natureza essa que, inclusive, é a justificativa para a adoção do regime da coisa julgada erga omnes e ultra partes criado pela LACP e pelo CDC.

Conforme salienta VIGLIAR, esse tratamento diferenciado da coisa julgada decorre da "natureza dos interesses que são veiculados na ação civil pública. É a indivisibilidade do interesse (seja essencial, seja acidental), na concepção de José Carlos Barbosa Moreira,

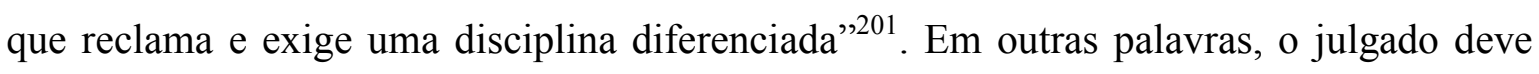
ser idêntico para todos os interessados, de forma que o benefício de um deve implicar, necessariamente, o benefício de todos, bem assim eventuais prejuízos.

Ora, se o interesse é essencialmente indivisível, como é possível limitar, na prática, os efeitos da coisa julgada a determinado território? Simplesmente, não é possível.

A título de exemplo, pensemos numa ação em que se discute a reparação de um dano ambiental (interesse difuso). Por certo, a sentença que julgar a ação procedente, determinando a reparação do dano, beneficiará tanto os moradores da comarca onde julgada a ação, como todos os outros integrantes da coletividade, titulares do direito (difuso) ao meio ambiente ecologicamente equilibrado.

A bem ver, ainda que a Lei n. 9.494/97 não queira, uma vez transitada em julgado a sentença, a sua execução implicará a recuperação do ambiente, em benefício de todos os interessados, mesmo que eles não residam na comarca do órgão prolator da decisão. Este é

${ }^{201}$ VIGLIAR, José Marcelo Menezes. A Lei 9.494..., op. cit., p. 70. 
um efeito prático da sentença proferida em ação civil pública que nenhuma Lei consegue retirar.

Segundo GRINOVER, quando se trata de interesses difusos, "a dimensão do problema se torna mais vasta, na medida em que a impossibilidade prática de se determinarem os titulares dos interesses torna mais ampla a extensão da coisa julgada, operando efetivamente erga omnes" ${ }^{202}$.

Idêntico raciocínio aplica-se às ações que têm por objeto interesses coletivos em sentido estrito, pois a indivisibilidade também lhes é intrínseca. De acordo com a lição de BARBOSA MOREIRA, no processo que visa a tutelar bens difusos ou coletivos, por sua própria natureza (leia-se: indivisibilidade), a coisa julgada há de operar erga omnes e ultra partes, respectivamente, pois o ar puro para um indivíduo implica necessariamente ar puro para todos. Por essa razão, mesmo para os interesses difusos e coletivos de abrangência nacional ou regional, não há como limitar o alcance da autoridade da coisa julgada a apenas alguns interessados. Logo, não há como aplicar a essas demandas a Lei n. 9.494/97.

Aliás, mesmo em situações alheias à jurisdição coletiva, "sempre que se decidam temas unitários, que não comportam fracionamento ou limitações geográficas" ${ }^{203}$, também se mostra inócua a tentativa de circunscrever a eficácia do julgado aos limites territoriais do órgão julgador. Sim, a questão é de eficácia do julgado, já que a coisa julgada, em si, tem apenas natureza adjetiva, ou seja, ela apenas agrega uma qualidade - a imutabilidade aos efeitos substantivos do julgado.

Daí porque é tecnicamente equivocado atrelar o instituto da coisa julgada ao da competência territorial, já que "o balizamento da coisa julgada é estabelecido pela relação jurídica material, que é moldada, por sua vez, pelo pedido e pela causa de pedir expostos na petição inicial" 204 .

\footnotetext{
${ }^{202}$ GRINOVER, Ada Pellegrini. Código Brasileiro de Defesa..., pp. cit., p. 904.

${ }^{203}$ Conforme MANCUSO, Rodolfo de Camargo. A concomitância de ações coletivas, entre si, e em face das ações individuais. In Revista dos Tribunais, ano 89, v. 782, São Paulo, dez. 2000, p. 44/45.

${ }^{204}$ MATTOS, Luiz Norton Baptista de. A litispendência..., op. cit., p. 205 (g.n.).
} 
Igual fundamento não se aplica ipsis literis aos interesses individuais homogêneos, embora a Lei n. 9.494/97 também lhes seja inócua. É que, como se sabe, os interesses individuais homogêneos não têm, intrinsecamente, natureza indivisível. Ao contrário, esses interesses são considerados divisíveis, justamente porque individuais. Em princípio, isto tornaria factível, do ponto de vista prático, a aplicação da Lei n. 9.494/97, devido à divisibilidade do objeto. Todavia, limitar a autoridade da coisa julgada aos limites territoriais do órgão prolator da sentença nas ações que têm por objeto interesses individuais homogêneos é o mesmo que multiplicar demandas (atomizá-las em vez de molecularizá-las), atribuindo menor peso político a cada uma delas, solucionando menos adequadamente esses conflitos, com possibilidade de decisões contraditórias (sendo o tratamento desigual de pessoas que se encontram em situação idêntica intolerável), com desprestígio e sobrecarga para o Judiciário, devido à propositura de inúmeras demandas fragmentárias.

Com efeito, a limitação do artigo 16 da LACP "desfigura, debilita, mutila e amesquinha" 205 a ação coletiva, projetada para o tratamento concentrado de diversas lides, gerando sua fragmentação em milhares de demandas (coletivas) repetitivas $e$ desnecessárias - tantas quantas forem as circunscrições judiciárias existentes no país.

Enfim, admitir a aplicação da Lei n. 9.494/97 às demandas coletivas, qualquer que seja a modalidade do interesse em jogo (difuso, coletivo ou individual homogêneo) é atuar na contramão da história e do próprio objetivo das ações coletivas.

Nesse sentido, merece destaque o valioso ensinamento de MANCUSO:

Por outras palavras, como a coisa julgada não é uma substância, e sim uma qualidade (= imutabilidade) que se agrega ao comando do julgado, $a$ expansão subjetiva dessa coisa julgada se dará até onde se encontre o interesse que constitui o objeto da demanda coletiva, e bem assim em face de todos os sujeitos concernentes a esse interesse ${ }^{206}$.

\footnotetext{
${ }^{205}$ MATTOS, Luiz Norton Baptista de. A litispendência..., op. cit., p. 205.

${ }^{206}$ MANCUSO, Rodolfo de Camargo. Manual do consumidor em juízo. São Paulo: Saraiva, 2001, p. 160 (g.n.).
} 
Por igual, MAZZILLI defende que:

A imutabilidade não será maior ou menor em decorrência da regra de competência que permitiu ao juiz decidisse a lide; a imutabilidade será mais ampla ou mais restrita de acordo, sim, com a natureza do direito controvertido e com o grupo social cujas relações se destine regular (interesses difusos, coletivos e individuais homogêneos) ${ }^{207}$.

É exatamente nisso que se constitui o efeito erga omnes ou ultra partes típico das ações coletivas, em alcançar todos aqueles que se encontrem na mesma situação fática ou jurídica tutelada naquela única ação coletiva. Daí porque o fato de a decisão produzir efeitos erga omnes ou ultra partes independe da competência do órgão prolator. Assim, tanto a sentença proferida por um juiz do Distrito Federal, quanto a decisão proferida por um juiz de Araçatuba terão a mesma eficácia erga omnes; o que diferencia uma sentença da outra é a abrangência do dano (nacional na primeira hipótese, e local na segunda), conforme os sujeitos concernentes ao interesse tutelado na ação se achem espalhados por todo o território nacional ou apenas no município de Araçatuba, respectivamente.

Porém, não bastassem todos esses argumentos, por si sós, suficientes para concluirse pela inoperância da Lei n. 9.494/97, vale salientar, ainda, mais um forte argumento para afastar a incidência da aludida regra. Segundo GRINOVER, a inoperância das regras contidas na nova redação do art. 16 da LACP também tem como base o seguinte argumento:

A competência territorial nas ações coletivas é regulada expressamente pelo art. 93 do CDC. E a regra expressa da lex specialis é no sentido da competência da capital do Estado ou do Distrito Federal nas causas em que o dano ou perigo de dano for de âmbito regional ou nacional. Assim, afirmar que a coisa julgada se restringe aos 'limites da competência do órgão prolator' nada mais indica do que a necessidade de buscar a especificação dos limites legais da competência: ou seja, os parâmetros do art. 93 do $\mathrm{CDC}$, que regula a competência territorial nacional e regional para os processos coletivos ${ }^{208}$.

\footnotetext{
${ }^{207}$ MAZZILLI, Hugo Nigro. A Defesa ..., op. cit., p. 264.

${ }^{208}$ GRINOVER, Ada Pellegrini. Código Brasileiro de Defesa..., op. cit., p. 921.
} 
E prossegue a autora, aduzindo que o âmbito da abrangência da coisa julgada é delimitado pelo pedido, e não pela competência. "Se o pedido é amplo (de abrangência nacional) não será por intermédio de tentativas de restrição da competência que o mesmo poderá ficar limitado"209. Ora, se o art. 93 do CDC trata de danos de âmbito regional ou nacional é porque a própria lei reconhece que a decisão de mérito, em função da amplitude da lesão, terá eficácia em todo o território nacional ou em toda a região onde ocorreu o dano.

Nesse sentido, MAZZILLI salienta que "o CDC estende a competência territorial do juiz prolator a todo o Estado ou a todo o País, conforme se trate de dano regional ou nacional (art. 93, II)”. E prossegue o autor, citando um acórdão do Tribunal Regional Federal da $4^{\text {a }}$ Região:

Os limites da competência territorial do órgão prolator de que trata o art. 16 da Lei 7.347/85 não são aqueles fixados na regra de organização judiciária quanto à competência do juízo, mas, sim, os que decorrem do art. 93 do $\mathrm{CDC}$ em função do alcance do dano que deu causa à demanda ${ }^{210}$.

\section{II.6.5. Conclusão}

Com base em tudo que se expôs, pode-se concluir pela inoperância das regras contidas na nova redação do art. 16 da $L A C P$, tendo em vista que não se pode limitar a abrangência da autoridade da coisa julgada nos processos coletivos às regras de competência, uma vez que "a decisão corresponderá ao pedido, não se podendo confundir as regras previstas nos incisos I, II e III do art. 103 do CDC, sobre os limites subjetivos da coisa julgada, com os institutos da jurisdição e da competência"211.

\footnotetext{
${ }^{209}$ MAZZILLI, Hugo Nigro. A Defesa ..., op. cit., p. 922/923.

${ }^{210}$ Idem, ibidem, p. 485 (g.n.).

${ }^{211}$ GRINOVER, Ada Pellegrini. Código Brasileiro de Defesa.., op. cit., p. 850/851. Apud LENZA, Pedro. Teoria..., op. cit., p. 284.
} 
A reforçar essa conclusão, vale lembrar, novamente, que a Lei n. 9.494/97 não alterou os artigos 93 e 103 do CDC, donde se conclui, por mais esse motivo, pela sua inoperância e inaplicabilidade.

Reconhecendo isso, o Anteprojeto de Código Brasileiro de Processos COLETIVOS DA USP restaura a sistemática das ações coletivas, ao prever em seu artigo 12, $\S 4^{\circ}$, que "a competência territorial do órgão julgador não representará limitação para a coisa julgada erga omnes". No mesmo sentido é a PROPOSTA DO MINISTÉRIO DA JUSTIÇA/SECRETARIA DE REFORMA DO JUDICIÁRIO (art. 29, caput), que põe fim a qualquer dúvida que, porventura, ainda possa existir.

No sentido oposto, e a despeito dos argumentos acima, destaca-se a Proposta de Emenda à Constituição PEC 358/2005, que confere ao Superior Tribunal de Justiça ("STJ") competência para definir a extensão territorial da decisão em ações civis públicas, quando a abrangência do dano ultrapassar a jurisdição de diferentes Tribunais Regionais Federais ou de Tribunais de Justiça de Estados ou do Distrito Federal. Todavia, referida Emenda, se aprovada, estará "inquinada de inconstitucionalidade, por ofensa aos princípios constitucionais da razoabilidade, da proporcionalidade, do acesso à justiça e da isonomia" ${ }^{, 212}$, além de contribuir para a insegurança jurídica, tendo em vista a falta de critérios objetivos para tal definição pelo STJ.

Por fim, vale ressaltar que a importância desse ponto para o escopo do presente trabalho reside no fato de que, se for considerada legítima/válida/constitucional a alteração do art. 16 da LACP, na análise da relação entre demandas coletivas, os limites da competência territorial do órgão prolator da decisão "passam a configurar na equação identificadora da ação, juntamente do pedido e da causa de pedir" ${ }^{\text {213 }}$.

\footnotetext{
${ }^{212}$ MATTOS, Luiz Norton Baptista de. A litispendência..., op. cit., p. 206.

${ }^{213}$ Idem, ibidem, p. 204.
} 


\section{II.6.6. O conflito de competência n. 47731/DF}

Em que pesem todas as "ressalvas" à Lei n. 9.494/97, a jurisprudência, por vezes, reconhece a sua aplicação, como ocorreu no julgamento do Conflito de Competência $\mathrm{n}^{\mathbf{o}}$ 47731/DF, pelo Superior Tribunal de Justiça, conforme voto vencedor do Ministro Teori Zavascki $^{214}$.

Trata-se de conflito de competência suscitado pela Anatel em face de Juízos Federais e de Direito com vistas à definição do juízo competente para julgar diversos feitos, de índole coletiva e individual, nos quais se discute a validade da cobrança da tarifa de assinatura básica pelas operadoras de serviço de telefonia fixo, sob a alegação, em síntese, de que a primeira demanda coletiva foi ajuizada perante a $3^{\text {a }}$ Vara Federal de Caxias do Sul (RS), posteriormente redistribuída para a $6^{\mathrm{a}}$ Vara Federal de Porto Alegre (RS), e, em seguida, várias ações, individuais e coletivas, foram propostas, com idêntico objeto, em todos os Estados da Federação.

Em seu voto vencedor, o Ministro Teori Zavascki concluiu pela inexistência de conflito de competência, seja positivo, ou negativo, consignando, dentre outros argumentos, que:

1) a mera possibilidade de sentenças divergentes sobre a mesma questão jurídica não configura, por si só, conflito de competência, cujo inconveniente o sistema busca minimizar com alguns instrumentos, v.g., uniformização de jurisprudência (CPC, art. 476), embargos de divergência (CPC, arts. 546 e 555, § $1^{\circ}$ ), edição de Súmulas (CPC, art. 479), fixação de precedentes;

2) considera-se, porém, existente o conflito positivo de competência diante da possibilidade de decisões divergentes em processos separados, envolvendo as mesmas partes e idêntica causa, como, por exemplo, propositura de ações populares e ações civis públicas relacionadas a mesmos direitos transindividuais, que se resolve pelo disposto no art. $5^{\circ}, \S 3^{\circ}$, da Lei n. $4.717 / 65$ e art. $2^{\circ}$, parágrafo único, da Lei n. $7.347 / 85$;

${ }^{214}$ No mesmo sentido, vide Resp 642.462/PR, Min. Eliana Calmon, 2005. 
3) no caso em exame, cuida-se de demandas com direitos individuais homogêneos, que podem ser tutelados por ação coletiva (substituto processual) ou individual, com plena autonomia na tramitação (CDC, arts. 103, III, $\S \S 2^{\circ}$ e $3^{\circ}$, e 104);

4) a existência de várias ações coletivas sobre a mesma questão jurídica não implica, por si só, a possibilidade de decisões antagônicas envolvendo as mesmas pessoas, pois os substituídos processuais (titulares do direito individual em favor de quem se pede a tutela coletiva) não seriam, obrigatoriamente, os mesmos em todas as demandas. Em regra, tratando-se de tutela de direitos individuais homogêneos, concorrem para a limitação do âmbito subjetivo dos substituídos, pelo menos, três fatores: a) a limitação da representatividade do órgão ou entidade autora (substituto processual), b) o âmbito do pedido formulado na demanda, c) a eficácia subjetiva da sentença imposta por lei nos limites territoriais do órgão prolator (Lei n. 9.494/97).

\section{II.7. Efetividade do processo coletivo}

Por fim, mas não menos importante, o presente Capítulo abordará a questão da efetividade do processo coletivo e como ela tem se mostrado na práxis forense.

Em termos semânticos, efetividade vem de efetivo, que quer dizer 'aquele que tem efeito real', 'aquilo que existe realmente'. Efetividade, portanto, é a 'atividade real', o 'resultado verdadeiro'.

Em termos processuais, efetividade significa atingir o resultado esperado, qual seja, eliminar a crise de direito material que ensejou o processo. Nas palavras de BEDAQUE, processo efetivo "é aquele que, observado o equilíbrio entre os valores segurança e celeridade, proporciona às partes o resultado desejado pelo direito material" ${ }^{215}$. Não por outro motivo, um dos escopos do processo, segundo a revolucionária doutrina de DINAMARCO, é justamente a pacificação social. A partir da visão instrumentalista do processo, este passou a ser visto não mais como um fim em si mesmo, mas como instrumento de solução de conflitos nas relações de direito material.

215 BEDAQUE, José Roberto dos Santos. Efetividade do Processo e Técnica Processual. São Paulo: Malheiros, 2006, p. 49. 
A partir dessa visão instrumentalista, a razão de ser do processo não é outra senão a prestação jurisdicional de forma efetiva, justa e tempestiva ${ }^{216}$. Impulsionados por essa nova teoria, os processualistas têm buscado mecanismos destinados a conferir à tutela jurisdicional efetividade cada vez maior, sempre pensando em um processo civil de resultados ${ }^{217}$.

Em que pesem todos os esforços e avanços legislativos nesse sentido, não se pode deixar de mencionar que, nem sempre, o processo atinge o resultado que dele se espera. Essa "frustração" pode ser ainda maior (e mais freqüente) no plano da jurisdição coletiva, por fatores que vão desde a complexidade dessas demandas, até a falta de institutos processuais adequados e o despreparo dos juízes para o trato dos interesses metaindividuais. A esse respeito, ASSAGRA pontua algumas das dificuldades enfrentadas no plano da jurisdição coletiva, dentre as quais se destacam: (i) o fato de as demandas coletivas incomodarem grandes interesses nacionais e internacionais, além dos freqüentes choques com o governo federal, que inúmeras vezes reagiu autoritariamente com a edição de medidas provisórias para restringir tutela jurisdicional coletiva ${ }^{218}$; e (ii) o fato de que a própria jurisprudência e parte da doutrina (ainda muito apegadas às regras ortodoxas do CPC e do CC) não têm plena consciência da importância da proteção e efetivação da tutela coletiva, o que se agrava com a dispersão e o distanciamento da sociedade em relação aos grandes problemas jurídicos vivenciados pelo país ${ }^{219}$.

Especificamente no caso da jurisprudência, tem-se apontado uma necessidade de

Mudança de mentalidade do Poder Judiciário, de modo a garantir uma ativa, crítica e compromissada participação de juízes atentos aos escopos maiores da jurisdição (...), impondo-se a revisão de práticas e posturas com o objetivo de garantir prioridade para o julgamento das ações

\footnotetext{
${ }^{216}$ Não se olvide que a tempestividade é um dos principais aspectos da prestação jurisdicional, na medida em que o fator tempo está diretamente relacionado à efetividade da jurisdição. Daí porque essa questão foi elevada a garantia constitucional, por força da Emenda Constitucional n ${ }^{\circ} 45$ : "a todos, no âmbito judicial e administrativo, são assegurados a razoável duração do processo e os meios que garantam a celeridade de sua tramitação" (inciso LXXVIII, do artigo $5^{\circ}$ da Constituição Federal - g.n.).

${ }^{217}$ Cf. BEDAQUE, José Roberto dos Santos. Efetividade..., op. cit., p. 17.

${ }^{218}$ A título de exemplo, citem-se as seguintes alterações da Lei 7.347/85: parágrafo único do artigo $1^{\circ}$ (Medida Provisória 2.180-35/01); e artigo 16 (Medida Provisória 1.570/97, posteriormente convertida na Lei 9.494/97), dentre outras.

${ }^{219}$ ALMEIDA, Gregório Assagra de. Direito material coletivo - superação da summa divisio..., op. cit., p. $569 / 591$.
} 
coletivas, superação de requisitos formais para enfrentamento do mérito e efetiva utilização de instrumentos processuais que assegurem efetividade aos provimentos judiciais ${ }^{220}$.

A falta de estrutura do Judiciário somada à falta de efetividade de suas decisões têm levado esse Poder a um descrédito, que, na visão de MESQUITA, não se limita aos jurisdicionados, mas, antes, aos próprios Poderes Executivo e Legislativo, que não reconhecem a autoridade das decisões judiciais. As razões da crise remontam, segundo o autor, à época do regime militar e, ainda hoje, não foram superadas. Nem mesmo as reformas por que passou o processo civil foram suficientes para projetar perante o povo a imagem do novo juiz, pelo qual tantos, há tanto tempo, estão esperando - ao contrário; na visão do autor, as reformas tendem a fazer com que a jurisdição contenciosa, e suas garantias, sejam absorvidas pela jurisdição voluntária, que se caracteriza pela relevação do critério da legalidade estrita ${ }^{221}$.

Dentre outros fatores que justificariam a baixa eficiência prática dos comandos judiciais, MESQUITA aponta o fato de esperar-se do processo a solução de crises que não são, propriamente, jurídicas. Como ensina o autor,

Lesões para cuja correção sejam necessários meios de outra natureza, como são os meios econômicos, financeiros, políticos técnicos, científicos, artísticos, etc., não constituem objeto da função jurisdicional. Constituem objeto da administração pública ou da função legislativa ${ }^{222}$.

\footnotetext{
${ }^{220}$ GAVRONSKI, Alexandre Amaral. Propostas para incrementar a efetividade dos instrumentos previstos na Lei n. 7.347/85 e ampliar o acesso à justiça nos direitos coletivos. In Ação Civil Pública - 20 anos da Lei 7.347/85. ROCHA, João Carlos de Carvalho, HENRIQUES F ${ }^{\circ}$, Tarcísio Humberto Parreiras, CAZETTA, Ubiratan (Coords.). Belo Horizonte: Del Rey, 2005, p. 124 e 127.

${ }^{221}$ MESQUITA, José Ignácio Botelho de. As novas tendências do direito processual: uma contribuição para o seu reexame. Teses, Estudos e Pareceres de Processo Civil. São Paulo: Revista dos Tribunais, 2005, v. I, p. $263 / 307$.

${ }^{222}$ Idem, ibidem, p. 293. O autor exemplifica sua afirmação nos seguintes termos: "uma medida de ordem econômica, como a elevação ou diminuição da taxa do câmbio, pode prejudicar intensamente o balanço das empresas de determinado setor, sem importar contudo qualquer lesão a direito. A solução, se necessária, terá que vir sob a forma de auxílio econômico, financeiro, ou tributário, e não pela modificação da taxa de câmbio por sentença".
} 
Especificamente no que tange à efetividade das decisões proferidas em ações coletivas, inúmeros casos há em que as decisões judiciais não atingem o resultado esperado, ou seja, não têm efetividade - sem embargo dos também numerosos casos em que a decisão surte efeitos práticos.

Como se sabe, uma das formas de o Judiciário recuperar sua credibilidade (e, por conseguinte, sua confiança e autoridade) é fazendo valer suas decisões. Para tanto, os juízes dispõem de meios coercitivos voltados à implementação de suas decisões, ou seja, à sua execução $o^{223}$. Com efeito, não há dúvida de que a execução / o cumprimento da sentença coletiva são uma das maiores "vitrines" do Poder Judiciário, sendo a "personificação" da efetividade do processo. Isso porque a atividade executiva “caracteriza-se, em sua essência, pelo fato de se dirigir à obtenção de resultados práticos, consubstanciados na realização dos direitos expressos na sentença ou no título extrajudicial" 224 . Como se sabe, por meio da atividade executória "o autor - exeqüente faz valer o seu direito à atividade sancionadora do Estado",225.

Analisando a questão no plano da jurisdição coletiva, SALLES pondera que a execução das decisões judiciais tem papel fundamental para que a ação civil pública cumpra sua finalidade de defesa dos interesses difusos e coletivos, uma vez que é nela que se podem aferir os resultados de um processo em sua dimensão prática. Em verdade, nesta seara, "efetividade do processo coloca-se vinculada a resultados práticos, servindo de importante referencial para a maneira pela qual os agentes moldam sua conduta a partir de uma determinada ação judicial"226. Diante da necessidade de maior comprometimento com o resultado concreto do processo, o autor defende que, em vez das medidas compensatórias (conversão em perdas e danos), deve-se dar prioridade à tutela específica, que consiste na reparação em espécie do dano, sendo (a única) capaz de "restaurar a distribuição de recursos sociais existentes antes do fato lesivo, na medida em que, ao reconstituir o próprio

\footnotetext{
${ }^{223}$ Sobre o tema, vide SALLES, Carlos Alberto de. Execução Judicial em Matéria Ambiental. São Paulo: Revista dos Tribunais, 1998.

${ }^{224}$ SALLES, Carlos Alberto de. Execução específica e Ação Civil Pública. In Ação Civil Pública após 20 anos - efetividade e desafios. MILARÉ, Édis. (Coord.). São Paulo: Revista dos Tribunais, 2005, p. 88. Sobre o direcionamento prático da execução, vide DINAMARCO, Cândido Rangel. Execução Civil. São Paulo: Malheiros, 1994, p. 111-112; e YARSHELL, Flávio Luiz. Tutela jurisdicional específica nas obrigações de declaração de vontade. São Paulo: Malheiros, 1993. p. 27.

${ }^{225}$ MESQUITA, José Ignácio Botelho de. Da ação civil. São Paulo: Revista dos Tribunais, 1975, p. 102.

${ }^{226}$ SALLES, Carlos Alberto de. Execução específica..., op. cit., p. 85/86.
} 
bem coletivo, contempla todos os interesses afetados" ${ }^{\text {227 }}$. Com efeito, dentre as espécies de obrigação descritas no artigo $3^{\circ}$ da LACP, a regra deve consistir em buscar-se, por todos os meios razoáveis, ir além da ressarcibilidade em seqüência ao dano, garantindo-se, ao contrário, a fruição do bem coletivo ${ }^{228}$.

No tocante à defesa do meio ambiente, especificamente, MIRRA ressalta que a natureza indisponível do bem difuso exige que o cumprimento da obrigação de fazer seja efetivamente garantido, sendo a reparação in natura a forma mais adequada - e mesmo indispensável - à recomposição integral do ambiente lesado. A medida compensatória (pecuniária) deve, portanto, guardar sempre o caráter de excepcionalidade, especialmente porque o dano ambiental não tem equivalente pecuniário, o que torna impossível sua conversão direta em unidades monetárias, para fins de cálculo do valor do prejuízo ${ }^{229}$.

Por essas e outras razões é que a tutela do ambiente reclama a instituição de novos instrumentos processuais, inclusive de execução, pois, como salienta SALLES,

As causas ambientais envolvem questões de elevada complexidade, implicando necessidade de conhecimento técnico e científico, variável grau de incerteza científica, apreciação de risco, grande número pessoas envolvidas, escolha de uma entre muitas alternativas de solução, vários órgãos com poder decisório sobre a matéria e efeitos distributivos decorrentes das medidas adotadas ${ }^{230}$.

\footnotetext{
${ }^{227}$ SALLES, Carlos Alberto de. Execução específica..., op. cit., p. 87. O autor cita como exemplo de medidas dirigidas à recomposição da integridade do bem lesado: a adoção de medidas para eliminar a emissão de poluentes, retirar do mercado um produto lesivo à saúde do consumidor, romper uma barreira arquitetônica impeditiva do acesso de portadores de deficiência a uma edifício.

${ }^{228}$ Nesse sentido, a PROPOSTA DO MINISTÉRIO DA JUSTIÇA/SECRETARIA DE REFORMA DO JUDICIÁRIO dispõe que: “Art. $24, \S 1^{\circ}$. A conversão em perdas e danos somente será admissível se inviável a tutela específica ou a obtenção do resultado prático correspondente e, no caso de interesses ou direitos coletivos ou individuais homogêneos, se houver interesse do grupo titular do direito".

${ }^{229}$ MIRRA, Álvaro Luiz Valery. Ação Civil Pública e a reparação do dano ao meio ambiente. São Paulo: Juarez de Oliveira, 2004, p. 325/326 e 346/348.

${ }^{230}$ TRUBEK, David M., Environmental defense I: introduction to interest group advocacy in complex disputes. In Public interest law: an economic and institutional analysis. WEISBROD, Burton A., HANDLER, Joel F., KOMESAR, Neil K. et al. (Org.). Berkeley: University of California Press, 1978. p. 102-194. Apud SALLES, Carlos Alberto de. Execução específica..., op. cit., p. 89. SALLES sustenta, ainda que o reconhecimento e equacionamento legal dos problemas afetos ao meio ambiente está estritamente relacionado com a forma pela qual se dá sua defesa em juízo, cumprindo analisar se as alternativas de resposta judicial permitem convenientemente atingir os objetivos de proteção ambiental que o sistema consagra. Em outras palavras, é preciso averiguar se o processo coletivo é efetivo, no sentido de produzir os resultados esperados (In Execução judicial de obrigação..., op. cit.,, p. 142).
} 
Nessa linha de raciocínio, merece destaque a alteração do artigo 461 do CPC, que, com clara inspiração nos artigos 11 da LACP e 84 do CDC, incluiu a tutela específica como remédio adequado e exigível àquelas obrigações de fazer e não fazer trazidas a juízo. A respeito do referido dispositivo, cumpre salientar que ele efetivamente prestigia em grau máximo o interesse do Estado em fazer obedecer os ditames de seus agentes políticos ${ }^{231}$, o que pode contribuir para a recuperação do prestígio, da confiança e da credibilidade do Poder Judiciário - às vezes, a qualquer custo.

Interessante notar que a primazia da efetividade do processo constitui, hoje, exceção ao próprio postulado da correlação entre a sentença e a demanda (arts. 128 e 460 do CPC), na medida em que o art. $461, \S 5^{\circ}$ autoriza a substituição / sub-rogação ${ }^{232}$ da obrigação por outra de resultado prático equivalente, o que "já não será a mesma pedida na inicial e concedida em sentença, que se mostrou ineficaz a proporcionar tal resultado"233. Essas ditas 'transgressões', inseridas no sistema por norma legal do mesmo nível das 'transgredidas', “contam com a plena legitimidade sistemática conferida pela promessa constitucional de acesso à justiça, a qual não se positiva sem a efetividade das decisões judiciárias" ${ }^{234}$.

É bem verdade que, mesmo com todo esse "aparato", em muitos casos, ainda é extremamente difícil executar as decisões proferidas em ações civis públicas, seja em razão da complexidade dos temas nela enfrentados (e dos vultosos valores envolvidos), seja pela ausência de instrumentos legais adequados para garantir o cumprimento das obrigações impostas $^{235}$. Nessas hipóteses, o sistema oferece mecanismos de coerção para o cumprimento de decisões judiciais (sejam elas liminares ou de mérito), os quais, todavia,

${ }^{231}$ Cf. CARMONA, Carlos Alberto. Novidades sobre a execução civil: observações sobre a Lei 11.232/2005. In A Nova Execução de Títulos Judiciais: comentários à Lei 11.232/05. RENAULT, Sérgio e BOTTINI, Pierpaolo (Orgs.). São Paulo: Saraiva, 2006, p. 56.

${ }^{232}$ Nesse sentido, WATANABE, Kazuo. Tutela jurisdicional dos interesses difusos: a legitimação para agir. In A tutela dos interesses difusos. GRINOVER, Ada Pellegrini (Org.). São Paulo: Max Limonad, 1984. A respeito da possibilidade de sub-rogação, ressalte-se que a proposta do Ministério da Justiça/Secretaria de Reforma do Judiciário reconhece expressamente essa possibilidade, conforme verbis: "Art. 24. Na ação que tenha por objeto a imposição de conduta de fazer, de não fazer, pagar ou de entregar coisa, o juiz determinará a prestação ou a abstenção devida, bem como a cessação da atividade nociva, em prazo razoável, sob pena de cominação de medida subrogatória ou de indução, independentemente de requerimento do autor".

${ }^{233}$ DINAMARCO, Cândido Rangel. Instituições de Direito Processual Civil. São Paulo: Malheiros, 2003, v. III, p. 245.

${ }^{234}$ Idem, ibidem.

${ }^{235}$ DIAS, Jefferson Aparecido. A efetividade das decisões proferidas em ações civis públicas. In Ação Civil Pública - 20 anos da Lei 7.347/85. ROCHA, João Carlos de Carvalho, HENRIQUES Fo, Tarcísio Humberto Parreiras, CAZETTA, Ubiratan (Coords.). Belo Horizonte: Del Rey, 2005, p. 98. 
nem sempre são suficientes para compelir o réu a cumprir as decisões, a exemplo do que ocorre com a fixação de penas de multas e, mesmo, com o crime de desobediência ${ }^{236}$. Talvez por isso processualistas que, no passado, defendiam que só a lide 'processualizada' interessa ao Poder Judiciário (o objeto litigioso do processo "limita-se à parcela de lide sociológica submetida à Justiça" ${ }^{237}$ ), passaram a reconhecer, em prol da efetividade do processo, que a sentença condenatória, nas relações continuativas, não resolve a lide socializada $^{238}$. No mesmo sentido, há bastante tempo MANCUSO vem defendendo os meios alternativos de solução de conflitos.

Isso justifica porque, nas demandas coletivas, o Compromisso de Ajustamento de Conduta, previsto no art. $5^{\circ}, \S 6^{\circ}$, da LACP, pode ser uma excelente alternativa. Frise-se que a composição em ação civil pública não só é possível como até aconselhável, tendo em vista que, mesmo sem abrir mão do direito difuso em jogo, ela propicia um resultado prático imediato, que levaria anos para, eventualmente, ser obtido com uma decisão judicial transitada em julgado. Nesse sentido, destaque-se a lição de MANCUSO:

Reza a sabedoria popular que 'é melhor um mau acordo do que uma boa demanda', ante os fatores imponderáveis e os custos inerentes a toda ação judicial, sem falar nas externalidades negativas, (...) decorrentes da própria pendência da controvérsia e da demora na sua resolução (...). De outro lado, haverá casos em que a não-celebração do acordo laboraria contra a tutela do interesse metaindividual objetivado. (...) Nas ações coletivas o interesse reside menos em 'vencer' a causa do que em obter, do modo menos oneroso, ou menos impactante, a melhor tutela para o conflito judicializado ${ }^{239}$.

Esse também é o posicionamento de FINK, para quem existe uma série de vantagens que podem ser trazidas pela celebração de acordos, como, por exemplo, o aumento da consciência da empresa e do aprendizado ambiental, a diminuição dos custos para o Judiciário, a solução mais rápida dos conflitos, etc.. Com efeito,

\footnotetext{
${ }^{236}$ DIAS, Jefferson Aparecido. A efetividade..., op. cit., p. 84.

${ }^{237}$ GRINOVER, Ada Pellegrini. A ação civil pública no STJ. A marcha do processo. Rio de Janeiro: Forense Universitária, 2000, p. 26.

${ }^{238}$ GRINOVER, Ada Pellegrini. Fundamentos da Justiça Conciliativa. Revista dos Tribunais. Cadernos de Direito Constitucional e Ciência Política, v. 14, p. 16-21, 2007.

${ }^{239}$ MANCUSO, Rodolfo de Camargo. A ação civil pública..., op. cit., p. 237 (g.n.).
} 
a composição negociada em boa parte dos casos traz vantagens em relação a uma sentença imposta à parte contrária. É oportuno lembrar que a solução judicial por via da sentença condenatória deve ser o último recurso. (...) Há vantagens do ajustamento de conduta em relação ao processo judicial representado pela ação civil pública. Portanto, antes de lançar mão de tão desgastante, cara e difícil solução para o conflito ambiental, deve-se buscar a via da negociação, por meio da qual todos encontrarão seus lugares e ao final do processo sairão muito mais fortalecidos do que se fossem obrigados a obedecer um comando frio e inexorável de uma sentença ${ }^{240}$. 


\section{CAPÍTULO III - RELAÇÃO ENTRE DEMANDAS COLETIVAS}

De posse dos conceitos até aqui tratados, o presente trabalho ingressa na análise do cabimento/pertinência da aplicação dos institutos processuais clássicos, voltados para solução da relação entre demandas intersubjetivas, à jurisdição coletiva, especialmente considerando as características peculiares dos interesses metaindividuais. Com base nos conceitos explorados nos capítulos anteriores, faz-se um confronto entre essas duas 'realidades', com vistas a investigar a possibilidade ou não de traslado dos conceitos tradicionais e individualistas do CPC para a jurisdição de massa. O presente capítulo aborda, assim, o conceito de identidade de ações, flexibilizando sua aplicação no plano da jurisdição coletiva, com ênfase não apenas na tríplice identidade, mas também no núcleo essencial da demanda, no thema decidendum, enfim, no bem jurídico tutelado, valendo-se para tanto da aplicação subsidiária da teoria da identidade da relação jurídica.

\section{III.1. Problemas decorrentes da concomitância / concorrência de ações $\operatorname{coletivas}^{241}$}

Como visto no Capítulo anterior, os interesses metaindividuais são aqueles que tocam ou que pertinem a um expressivo grupo de pessoas ou mesmo à inteira coletividade, 'trifurcando-se' em difusos, coletivos em sentido estrito e individuais homogêneos. Das características intrínsecas dos direitos metaindividuais decorrem as seguintes

\footnotetext{
241 Embora haja discussões acadêmicas acerca do adequado nomen juris deste peculiar instrumento processual de tutela dos interesses transindividuais - ação civil pública ou ação coletiva - o presente trabalho adota a expressão ação coletiva, seja porque (i) trata-se de expressão mais genérica, que abrange outras “espécies” de ação que não apenas a Ação Civil Pública, como também o Mandado de Segurança Coletivo e as Ações de Controle de Constitucionalidade; seja porque (ii) na linha do que preleciona GRINOVER, esta terminologia respeita "à legitimação para a causa (também atribuída, pela lei, às formações sociais) e aos bens protegidos (interesses de dimensão coletiva)" (In Ações coletivas para a tutela do ambiente e dos consumidores - a Lei 7.347, de 24.07.1985. Revista de Processo, São Paulo: Revista dos Tribunais, n. 44, 1986, p. 124, nota 1). No mesmo sentido: A defesa dos interesses difusos em juizo: meio ambiente, consumidor, patrimônio cultural, patrimônio público e outros interesses. São Paulo: Saraiva, 2005, p. 110) e VIGLIAR, José Marcelo Menezes (Ação civil pública ou ação coletiva?. In Ação civil pública: Lei 7.347/85 - 15 anos. MILARÉ, Édis (Coord.). São Paulo: Revista dos Tribunais, 2001. p. 409, 410 e 416). Em adição, cumpre salientar que o ANTEPROJETO DE CóDIGo BRASILEIRO DE PROCESSOS COlETIVOS DA USP utiliza-se da expressão ações coletivas (art. $1^{\circ}$ ), ao passo que a PROPOSTA DO MINISTÉRIO DA JUSTIÇA/SECRETARIA DE REFORMA DO JUDICIÁRIO vale-se das duas expressões ("Art. 1'. Regem-se pelas disposições desta Lei, as ações civis públicas e as demais ações coletivas destinadas à proteção").
} 
peculiaridades processuais, dentre outras: (i) a legitimação para agir é extraordinária, sob a forma concorrente-disjuntiva, facultando-se a vários co-legitimados a propositura de ação, em nome próprio, no interesse da coletividade; (ii) a coisa julgada é erga omnes ou ultra partes, ampliando-se os limites subjetivos do julgado; (iii) o objeto é indivisível, o que confere aos interesses metaindividuais um tratamento unitário, de forma que a satisfação de um interessado implica necessariamente a satisfação de todos.

Da vivência e análise desses três pontos nevrálgicos, conclui-se que a legitimação aberta pode ensejar a propositura de mais de uma ação coletiva por diferentes colegitimados, todas com efeitos erga omnes e objeto indivisível.

Ao dispor sobre as razões de uma possível concomitância entre demandas coletivas, MANCUSO salienta que a indivisibilidade do objeto, aliada ao regime de legitimação aberta, "deferida concorrente e disjuntivamente a um número expressivo de sujeitos, entidades e órgãos públicos, acabam por ensejar a virtualidade de intercorrência de mais de uma ação coletiva" ${ }^{242}$, especialmente em um país de dimensão continental como o Brasil.

A justaposição entre ações de tipo coletivo traz complicações ainda maiores, tendo em vista que, nesse caso,

Os perigos redobram, por conta da projeção erga omnes ou ultra partes da coisa julgada, caso em que a virtual prolação de comandos de conteúdo diverso vai engendrar contradição que não se conterá apenas no plano lógico, mas desbordará para o plano prático, como facilmente se deduz ${ }^{243}$.

Tais complicações intensificam-se, ainda mais, nas ações por danos ao meio ambiente - bem difuso, por excelência -, em que o objeto é incindível, de tal forma que a propositura de mais de uma ação coletiva por diferentes co-legitimados, todas com efeitos erga omnes, pode acarretar a prolação de comandos antagônicos. Com efeito, a indivisibilidade do objeto é fator determinante para que as ações versando sobre interesses

\footnotetext{
${ }^{242}$ Conforme MANCUSO, Rodolfo de Camargo. A concomitância de ações coletivas, entre si..., op. cit., p. 37 (g.n.).

${ }^{243}$ Idem Ibidem.
} 
essencialmente coletivos (difusos e coletivos em sentido estrito) recebam tratamento unitário e solução uniforme ${ }^{244}$.

Isso porque a contradição de julgados, no mais das vezes, terá desdobramentos no plano prático e não apenas lógico, como no exemplo citado por LEONEL:

Considerando que a relação jurídica de direito material era uma só (decorrente, v.g., das lesões ambientais decorrentes de certa conduta), ficaria a dúvida: qual das duas decisões está correta? A que reconheceu a prática da lesão e a responsabilidade dela decorrente, ou a que a negou? ${ }^{245}$.

A dúvida é pertinente e decorre do fato de que a contradição de julgados "acontece quando o bem da vida assegurado numa decisão de mérito vem suprimido, esvaziado ou obstaculizado por outro comando judicial" ${ }^{246}$. Não por outro motivo a contradição entre os resultados práticos do processo é considerada inaceitável ${ }^{247}$, afinal, uma coisa não pode, ao mesmo tempo, ser e não ser. A prolação de decisões conflitantes, além de desprestigiar o Judiciário, enfraquece a autoridade das decisões judiciais e esvazia sua validade e eficácia, violando as garantias da isonomia e do non bis in idem.

Mais do que isso. A prolação de comandos com resultados práticos contraditórios (ambos com alcance erga omnes) implicará, no fim, o desrespeito a um deles, o que não é tolerado pelo nosso sistema ${ }^{248}$. Nesse sentido, GRINOVER ressalta que:

A multiplicidade dessas ações coletivas, versando a mesma situação de direito material respeitante a uma pluralidade de pessoas, pode gerar não é difícil entrever - situações insustentáveis ou, nas felizes e

\footnotetext{
${ }^{244}$ Nesse sentido, MENDES, Aluísio Gonçalves de Castro. Ações coletivas no direito comparado e nacional. São Paulo: Revista dos Tribunais, 2002, p. 260.

${ }^{245}$ LEONEL, Ricardo de Barros. Causa de pedir e pedido nos processos coletivos: uma nova equação para a estabilização da demanda. In Direito Processual Coletivo e o Anteprojeto de Código Brasileiro de Processos Coletivos. GRINOVER, Ada Pellegrini, MENDES, Aluisio Gonçalves de Castro e WATANABE, Kazuo (Coords.). São Paulo: Revista dos Tribunais, 2007, p. 153 (g.n.).

${ }^{246}$ MANCUSO, Rodolfo de Camargo. A concomitância de ações coletivas, entre si..., op. cit., p. 35 (g.n.).

${ }^{247}$ Sobre a incompatibilidade lógica - aceitável - e incompatibilidade prática - inaceitável - entre coisas julgadas, vide GRINOVER, Ada Pellegrini. Eficácia e autoridade da sentença penal. São Paulo: Revista dos Tribunais, 1978, p. 12.

${ }^{248}$ LEONEL, Ricardo de Barros. Manual.., op. cit., p. 249.
} 
atualíssimas palavras de Kazuo Watanabe 'contradições tão flagrantes de julgados' que 'povo algum terá estrutura suficiente para absorver com tranqüilidade e paciência por muito tempo'. Desarmonia dessa ordem põe em sério risco o próprio prestígio do Poder Judiciário, que dificilmente teria 'condições bastantes para resistir por muito tempo a tamanho desgaste ${ }^{249}$.

Daí o acerto da afirmação de MENDES, para quem "o processamento, por vezes, concomitante de demandas coletivas, na realidade brasileira, vem sendo motivo de insegurança e de descrédito para a própria tutela coletiva"250.

A isso, acrescente-se o argumento de que o mote do processo/fase de conhecimento é justamente a eliminação de incerteza. Ou seja, a partir do momento em que se têm duas decisões contraditórias sobre um mesmo bem jurídico coletivo, e ambas com efeitos erga omnes, a jurisdição acaba contribuindo para o aumento das incertezas, contrariando sua própria finalidade.

Se não for para atingir o fim de pacificar os conflitos coletivos, eliminando a crise de direito material, não há porque oferecer acesso à justiça. Afinal, as ações coletivas devem ser capazes de pacificar para o presente e para o futuro e de evitar as incertezas de julgados conflitantes em torno de uma tese jurídica só ${ }^{251}$. Em suma: os problemas que podem advir da concomitância entre ações coletivas são gravíssimos e, por isso, devem ser evitados - ainda que tenhamos de abrir mão da rigidez de certos institutos processuais clássicos.

\footnotetext{
${ }^{249}$ GRINOVER, Ada Pellegrini, et alii. Código Brasileiro de Defesa..., op. cit., p. 940.

${ }^{250}$ MENDES, Aluísio Gonçalves de Castro. O Anteprojeto de Código Modelo de Processos Coletivos para os Países Ibero-Americanos e a legislação brasileira. Gênesis - Revista de Direito Processual Civil 31/11, jan.mar. 2004, p. 11.

${ }^{251}$ DINAMARCO, Cândido Rangel. A instrumentalidade do processo. São Paulo: Malheiros, 1998, p. 303 (g.n.).
} 


\title{
III.2. Inadequação dos institutos processuais clássicos
}

Em que pesem o expressivo número de casos de concomitância de ações coletivas com o mesmo fim e os problemas práticos que podem advir dessa situação, não existe, até hoje, em nosso microssistema processual coletivo, um regramento específico para o tema $^{252}$. A concomitância de ações coletivas entre si, especialmente o instituto da litispendência, não veio tratada na Lei da Ação Popular, nem na Lei da Ação Civil Pública, nem no Código de Defesa do Consumidor ${ }^{253}$, acarretando a necessidade de traslado e aplicação, nas ações coletivas, de institutos clássicos e individualistas do Código de Processo Civil.

Todavia, como adverte MANCUSO,

\begin{abstract}
A aplicação de institutos e categorias da jurisdição singular para o plano coletivo nem sempre será possível, ou nem sempre será segura, de modo que devem intérprete e aplicador proceder com toda cautela nesse transporte, atentando a que o plano da jurisdição coletiva parte de pressupostos que lhe são peculiares e intenta alcançar finalidades específicas, aqueles e estas bem diversos de seus correspondentes na jurisdição singular ${ }^{254}$.
\end{abstract}

Daí se dizer que os tradicionais institutos da conexão, continência, prevenção, litispendência e coisa julgada, previstos no $\mathrm{CPC}$, não podem ser transplantados, sic et simpliciter, para o plano da jurisdição coletiva.

\footnotetext{
${ }^{252}$ Nesse sentido, Antonio GIDI afirma que o CDC “omite-se, inexplicavelmente, quanto à litispendência entre demandas coletivas" (In Coisa julgada..., op. cit., p. 218).

${ }^{253}$ Ressalva seja feita aos artigos $5^{\circ}, \S 3^{\circ}$, da Lei da Ação Popular; $2^{\circ}$, parágrafo único, da Lei da Ação Civil Pública; e 104 do Código de Defesa do Consumidor.

${ }^{254}$ MANCUSO, Rodolfo de Camargo. Jurisdição Coletiva e Coisa Julgada - Teoria Geral das Ações Coletivas. São Paulo: Revista dos Tribunais, 2006, p. 112, passim (g.n.).
} 
De modo enfático, WAMBIER assevera que o modelo definido pelo CPC para a constatação de conexão e litispendência "não serve para regular o confronto entre duas ações coletivas, a não ser que seja aplicado de outro modo, tendo em vista as peculiaridades de tais ações" 255 . Por igual, MATTOS entende que, no tocante às ações coletivas confrontadas entre si, "o instituto da litispendência não pode ser tratado nos moldes do processo civil comum, de cunho individualista, sem um temperamento das regras contidas no Código de Processo Civil"256.

Como pontua OVÍDIO BAPTISTA, a influência exercida pelo individualismo sobre o processo civil é enorme, a ponto de causar dificuldade toda vez que o processo civil "tem de lidar com direitos supra-individuais, com as ações coletivas, para as quais a maioria das categorias tradicionais tornam-se imprestáveis" ${ }^{257}$.

De fato, diante das peculiaridades dos conflitos surgidos no âmbito da contemporânea sociedade de massa, o legislador e os operadores do direito podem optar por um de dois caminhos: (a) adotar o sistema tradicional ou (b) inovar ${ }^{258}$. Expressões como aplicado de outro modo, temperamento e imprestáveis - acima citadas e destacadas - exigem que o presente trabalho proponha a inovação, a modernização, a adequação, a adaptação, enfim, a flexibilização dos institutos processuais clássicos. A propósito, GIDI sugere que:

$\mathrm{Na}$ compreensão dos institutos de direito processual e material referentes aos direitos coletivos, é fundamental haver certa dose da inventiviness do magistrado americano, que VIGORITTI traduziu em termos de coraggio e fantasia. É preciso criatividade na aplicação e interpretação dos novos institutos $^{259}$.

\footnotetext{
${ }^{255}$ WAMBIER, Teresa Arruda Alvim. Litispendência em ações coletivas. In Processo Civil Coletivo. MAZZEI, Rodrigo e NOLASCO, Rita Dias (Coords.). São Paulo: Quartier Latin, 2005, p. 290, passim (g.n.). ${ }^{256}$ MATTOS, Luiz Norton Baptista de. A litispendência..., op. cit., p. 197 (g.n.).

${ }^{257}$ SILVA, Ovídio Baptista da, GOMES, Fábio. Teoria Geral do Processo Civil. São Paulo: Revista dos Tribunais, 2002, p. 36 (g.n.).

${ }^{258}$ Cf. LEONEL, Ricardo de Barros. Causa de pedir e pedido nos processos coletivos: uma nova equação para a estabilização da demanda. In Direito Processual Coletivo e o Anteprojeto de Código Brasileiro de Processos Coletivos. GRINOVER, Ada Pellegrini, MENDES, Aluisio Gonçalves de Castro e WATANABE, Kazuo (Coords.). São Paulo: Revista dos Tribunais, 2007, p. 153.

${ }^{259}$ GIDI, Antonio. Coisa julgada..., op. cit., p. 113. No mesmo sentido, cite-se ARAKEN DE ASSIS: "a difícil e perigosa passagem do direito processual de tutela de interesses interindividuais para o direito
} 


\section{III.2.1. Necessidade de flexibilização das regras processuais}

De forma geral, pode-se afirmar que os institutos processuais clássicos não se mostram perfeitamente adequados à jurisdição coletiva, especialmente no que tange aos problemas advindos da relação entre demandas coletivas. Tal realidade, aliada ao pensamento do processo civil de resultados, propicia a revisão de antigos "dogmas" do direito processual clássico, à luz das peculiaridades que decorrem da própria essência dos interesses metaindividuais.

O que tem sido proposto, doutrinariamente, não é o rompimento com o processo civil tradicional, mas seu aproveitamento com modernização e avanço, adaptando-o às exigências da atualidade e dos conflitos coletivos ${ }^{260}$. Essa modernização se justifica, na medida em que não há como pensar em um processo coletivo de resultados, sem uma "prudente ousadia, expressada tanto na adaptação criativa do existente, como na instituição ex novo de figuras ou técnicas processuais, onde haja carência ou insuficiência de elementos" 261 .

De fato, para que o processo civil continue sendo um instrumento de composição justa de conflitos, os institutos processuais clássicos hão de ser relidos e readaptados, devendo amoldar-se às novas necessidades da sociedade de massa ${ }^{262}$. Mais do que isso, no trato das demandas coletivas, os operadores do direito devem estar desarmados do pensamento individual ${ }^{263}$.

Porém, como se sabe, ainda hoje, os juízes têm aplicado às lides coletivas alguns institutos típicos dos conflitos interssubjetivos, gerando entraves à garantia constitucional de acesso à ordem jurídica justa. Como salienta MANCUSO:

processual coletivo exige apuro metodológico e, principalmente, mente aberta" (TJRS - Apelação Cível n. 70014404784, rel. Des. Araken de Assis, j. 12.04.2006 - g.n.).

${ }^{260}$ Cf. LEONEL, Ricardo de Barros. Causa de pedir..., op. cit., p. 145.

${ }^{261}$ MANCUSO, Rodolfo de Camargo. Jurisdição Coletiva..., op. cit., p. 104 (g.n.).

${ }^{262}$ Nesse sentido, MANCUSO, Rodolfo de Camargo. Ibidem, p. 7 (g.n.).

263 Cf. RODRIGUES, Marcelo Abelha. Ação Civil Pública e Meio Ambiente. Rio de Janeiro: Forense Universitária, 2004. p. 13 (g.n.). 
Helas, fatores diversos, que vão da mera desinformação até o desinteresse pelo estudo e acompanhamento da evolução do Direito, especialmente o Processual, têm levado a lamentáveis equívocos no trato judiciário de conflitos metaindividuais, não raro baralhando-se conceitos e categorias que relevam dos planos coletivo e individual, tudo resultando em situações de perplexidade e de injustiça, com graves prejuízos para muitos jurisdicionados e desprestígio para o Judiciário ${ }^{264}$.

Dentre os institutos processuais clássicos que têm sido transplantados da jurisdição individual para a coletiva sem o necessário temperamento estão aqueles destinados à solução dos problemas decorrentes da relação entre demandas. Nesse sentido, WAMBIER salienta que, para a aferição da ocorrência de litispendência entre ações coletivas, "a jurisprudência tem aplicado critérios equivocados, já que recolhe da letra do CPC e da doutrina que a estes critérios se refere" ${ }^{265}$. O equívoco consistiria no fato de a jurisprudência se valer (desacertadamente) dos mesmos critérios que regulam o tema quanto às ações individuais.

Por conta disso, a doutrina tem defendido, a partir dos resultados colhidos do dia-adia forense e dos debates acadêmicos, que as soluções oferecidas pelos processos coletivos podem e devem ser aperfeiçoadas. Para tanto, pode-se pensar na reunião dos princípios e normas gerais atinentes aos processos coletivos em um estatuto codificado, "dando tratamento sistemático e atual para a tutela coletiva, bem como preenchendo as lacunas existentes e dando respostas às dúvidas e controvérsias que grassam no meio jurídico"266. À evidência, além do avanço legislativo, também é indispensável que o intérprete adote esse novo método de pensamento e que os juízes sejam capazes de dar ao seu instrumento de trabalho a dimensão que os tempos exigem ${ }^{267}$.

\footnotetext{
${ }^{264}$ MANCUSO, Rodolfo de Camargo. A concomitância de ações coletivas, entre si..., op. cit., p. 29.

${ }^{265}$ WAMBIER, Teresa Arruda Alvim. Litispendência em ações coletivas. In Tutela Coletiva - 20 anos da Lei da Ação Civil Pública e do Fundo de Defesa de Direitos Difusos e 15 anos do Código de Defesa do Consumidor. LUCON, Paulo Henrique dos Santos (Coord.). São Paulo: Atlas, 2006, p. 269.

${ }^{266}$ Texto extraído da apresentação do Anteprojeto elaborado em conjunto nos programas de pós-graduação stricto sensu da Universidade do Estado do Rio de Janeiro (UERJ) e da Universidade Estácio de Sá (UNESA).

${ }^{267}$ DINAMARCO, Cândido Rangel. A instrumentalidade..., op. cit. .
} 
Metaforicamente, FABRÍCIO salienta que "quando o agigantamento do usuário faz romper o tecido e rebentar as costuras, já não é o caso para remendos ou ajustes: a roupa toda tem de ser substituída" ${ }^{268}$. Todavia, enquanto essa codificação não se concretiza (enquanto a 'nova roupa' não fica pronta), pode-se trabalhar com o redimensionamento dos institutos processuais com base na própria instrumentalidade do processo.

\section{III.2.1.1. Instrumentalidade do processo e instrumentalidade das formas}

Decorre da doutrina de DINAMARCO a afirmação de que o processo tem por escopo a pacificação social, no sentido de que "o processo alimenta-se das crises jurídicas preexistentes e, quando termina, apresenta um resultado consistente na sua eliminação" 269 . Ressalta-se, neste ponto, a instrumentalidade do processo, que consiste, justamente em dotá-lo de meios, funcionalidade, características e institutos aptos a fazer com que realmente atinja sua finalidade de servir efetivamente como instrumento destinado à composição de conflitos concretos da vida real. Em suma, o processo deve ser apto a equacionar os problemas que justificam sua própria existência.

Com isso em mente, torna-se mais fácil compreender e aceitar propostas de flexibilização dos (rígidos) institutos processuais clássicos, de origem romanística. A partir dessa visão instrumentalista, a razão de ser do processo não é outra senão a pacificação social, que se alcança por meio de um processo équo e justo.

Impulsionados por essa nova teoria, pouco a pouco, os processualistas deixaram de "se preocupar exclusivamente com conceitos e formas para buscar mecanismos destinados a conferir à tutela jurisdicional o grau de efetividade que dela se espera"270. A partir dessas premissas, tornou-se necessário rever também a técnica processual, para adequá-la à visão instrumentalista do processo.

\footnotetext{
${ }^{268}$ FABRÍCIO, Adroaldo Furtado. As novas necessidades do processo civil e os poderes do juiz. In $O$ Judiciário e a Constituição. TEIXEIRA, Sálvio de Figueiredo (Org.). São Paulo: Saraiva, 1994. Apud GIDI, Antonio. Coisa julgada..., op. cit., p. 58.

${ }^{269}$ DINAMARCO, Cândido Rangel. Instituições..., op. cit., p. 181.

${ }^{270}$ BEDAQUE, José Roberto dos Santos. Efetividade..., op. cit., p. 17.
} 
Assim, pensando-se em um processo de resultados, não mais se admite que a técnica processual constitua óbice a que se atinjam os escopos do processo. Ao contrário, a técnica visa a proporcionar que o instrumento cumpra sua finalidade de eliminar a crise de direito material. Isso porque as exigências formais do processo não passam de técnicas destinadas a "impedir abusos e conferir certeza aos litigantes (due process of law), [o que] manda que elas não sejam tratadas como fins em si mesmas, senão como instrumentos $a$ serviço de um fim" ${ }^{271}$. Daí se dizer que a técnica processual está a serviço do processo e este, por sua vez, a serviço da ordem jurídica material, tendo por escopo a pacificação social.

Não há dúvida de que a técnica processual confere segurança e regularidade ao instrumento. Para o bom desenvolvimento do processo, é preciso observar os requisitos formais de cada um dos atos processuais indicados na lei, bem como a seqüência temporal em que tais atos devem ocorrer. No entanto, o processo não pode ser escravo da forma, já que "o apego exagerado ao formalismo acaba por transformar o processo em mecanismo burocrático e o juiz no burocrata incumbido de conduzi-1o"272. Por essa razão e para evitar que a estrita observância do formalismo não comprometa os objetivos e a própria efetividade do processo, BEDAQUE sustenta que devemos extrair do sistema positivo soluções aptas a compatibilizá-los ${ }^{273}$.

Como síntese desses pensamentos, merece destaque a lição de DINAMARCO, ao ressaltar que a jurisprudência, com arrimo na doutrina, vem abrandando a rigidez de algumas técnicas processuais, o que, a seu ver, legitima-se, tendo em vista que "a extremada rigidez seria fator de inevitável burocratização do processo, (...) afastando o processo de seu primordial objetivo de fazer justiça (processo justo e équo)"274.

A bem ver, analisando-se a técnica processual à luz da instrumentalidade do processo, é possível admitir que os institutos da litispendência, coisa julgada, conexão e continência sejam relativizados em sede de jurisdição coletiva, para possibilitar que o resultado do processo reflita a vontade do direito material, atingindo-se os escopos do processo.

\footnotetext{
${ }^{271}$ DINAMARCO, Cândido Rangel. Instituições..., op. cit, p. 600.

${ }^{272}$ BEDAQUE, José Roberto dos Santos. Efetividade..., op. cit., p. 45.

${ }^{273}$ Idem, ibidem, p. 44.

${ }^{274}$ DINAMARCO, Cândido Rangel. Ibidem, p. 460 (g.n.).
} 
Nesse sentido, SALLES enfatiza que, diante dos novos desafios apresentados, o processo passa a ser pautado por objetivos mais amplos, destinados a verificar a necessidade de modelos processuais mais flexíveis. Dessa maneira, o exercício do poder jurisdicional poderá tornar-se mais maleável, aderente à realidade social e apto a criar condições para construção de sua efetividade ${ }^{275}$.

Por fim, cumpre ressaltar a importância da ampliação dos poderes do juiz, como forma de atingirem-se os escopos do processo. Nas palavras de BEDAQUE, "é preciso abandonar a idéia de que os atos processuais devem atender rigorosamente a determinada forma previamente estabelecida, não tendo o juiz poderes para flexibilizar os rigores da lei”276. Na visão do autor, o formalismo exagerado é incompatível com a própria visão social do processo. Tal característica acentua-se nos casos de jurisdição coletiva. Daí sustentar MANCUSO que o processo deve ser visto como meio de acesso à ordem jurídica justa, "objetivo que, sob a perspectiva de uma sociedade impactada pelos conflitos de massa, deve vir qualificado pela especial aptidão a alcançar uma resposta judiciária eficaz e aderente a essa nova realidade"277.

Assim, como reflexo da instrumentalidade do processo, a instrumentalidade das formas recomenda sua flexibilização, como condição à viabilização do direito material. Afinal, o processo é meio para atingir-se esse fim. Encampando essa idéia, o MINISTÉRIO DA JUSTIÇA/SECRETARIA DE REFORMA DO JUDICIÁRIO, em sua proposta de alteração da Lei da Ação Civil Pública, destaca como princípios do Processo Civil Coletivo a "máxima instrumentalidade, amplitude e utilidade da tutela jurisdicional coletiva" e a "flexibilização e adequação da técnica processual" (art. $5^{\circ}$, V e VI).

\footnotetext{
${ }^{275}$ SALLES, Carlos Alberto de. Execução judicial de obrigação..., op. cit., p. 12 (g.n.).

${ }^{276}$ BEDAQUE, José Roberto dos Santos. Efetividade..., op. cit., p. 108.

${ }^{277}$ MANCUSO, Rodolfo de Camargo. Jurisdição Coletiva..., op. cit., p. 5 (g.n.).
} 


\section{III.3. Teoria da tríplice identidade obtemperada pela teoria da identidade da relação jurídica ${ }^{278}$}

Não só os institutos da conexão, continência, prevenção, litispendência e coisa julgada devem ser flexibilizados no plano da jurisdição coletiva, como também - e antes deles - o próprio conceito de identidade de ações.

Como visto no Capítulo I, em algumas situações concretas, a teoria da tríplice identidade mostra-se insuficiente para desempenhar o papel que the é reservado no confronto de duas ou mais ações. Por esse motivo, a despeito de sua adoção expressa pelo CPC, a doutrina e a jurisprudência devem procurar soluções para determinadas questões que extravasam os seus limites ${ }^{279}$.

Com efeito, diante de situações excepcionais, que revelem a insuficiência da teoria dos tria eadem, é possível pensar na aplicação subsidiária da teoria da identidade da relação jurídica ${ }^{280}$. Nessa linha de raciocínio, cite-se novamente a lição de ARRUDA ALVIM, para quem

\footnotetext{
Se os fatos das duas demandas deixarem margem à dúvida, quanto à respectiva identificação, deverá o intérprete aprofundar-se no exame da relação jurídica deduzida em juízo e, entendendo que são idênticas (a da primeira e da segunda ação), como também as conseqüências jurídicas pedidas, deverá obstar a segunda demanda ${ }^{281}$.
}

O abrandamento da teoria da tríplice identidade, proposto por ARRUDA ALVIM e CRUZ E TUCCI para o processo civil individual, pode ser ainda mais útil no plano da jurisdição coletiva, porque aqui o problema apresenta-se de forma muito mais complexa.

\footnotetext{
${ }^{278}$ Mais adiante, no item III.5.1, será analisada a questão sob o enfoque da identidade do bem jurídico tutelado, mais específico e adequado ao escopo do presente trabalho.

${ }^{279}$ Cf. CRUZ E TUCCI, José Rogério. A causa petendi..., op. cit., p. 213.

${ }^{280}$ Nesse sentido, CRUZ E TUCCI, José Rogério. Ibidem, p. 213.

281 ARRUDA ALVIM. Ensaio sobre a litispendência no Direito Processual Civil. São Paulo: Revista dos Tribunais, 1970, v. II, p. 103 (g.n.).
} 
Note-se que, em nenhum momento, propõe-se o rompimento com a teoria da tríplice identidade. O presente trabalho propõe, apenas, uma abertura para critérios subsidiários, que possam auxiliar na difícil tarefa de identificar demandas coletivas - o que se faz com amparo em doutrinadores de escol. De fato, a individualização das demandas coletivas, em muitos casos, necessitará uma ampliação dos critérios utilizados, extrapolando os tradicionais tria eadem. Mais do que isso, no plano da jurisdição coletiva, a operação de identificação de demandas não poderá ser tão rígida a ponto de exigir-se a identidade absoluta de partes, pedido e causa de pedir.

Isso porque, se já é difícil encontrar demandas absolutamente idênticas no plano da jurisdição singular, que dizer das ações coletivas, que apresentam peculiaridades processuais como a legitimação extraordinária, o efeito erga omnes da coisa julgada e a indivisibilidade do objeto. Nesse sentido, MENDES salienta que a definição tradicional de identidade, a partir dos três elementos - partes, pedido e causa de pedir - por certo não condiz com a realidade da tutela coletiva e a pluralidade de legitimados ${ }^{282}$.

Assim, a simples possibilidade de a teoria da tríplice identidade revelar-se insuficiente em determinados casos concretos permite a adoção subsidiária da teoria da identidade da relação jurídica para solucionar os problemas decorrentes da relação entre demandas coletivas.

Nesse sentido, merece destaque a posição vanguardista de LEONEL, que propõe a adoção de critérios subsidiários para caracterizar devidamente a conexão, a continência, a litispendência e a coisa julgada no âmbito das ações coletivas, não se limitando a identificar os três elementos da ação (tria eadem), mas, também, a relação jurídica material $^{283}$. Por ser aplicada subsidiariamente, a teoria da identidade da relação jurídica não exclui nem afasta a teoria da tríplice identidade, que apenas virá obtemperada por aquela.

\footnotetext{
${ }^{282}$ MENDES, Aluísio Gonçalves de Castro. O Anteprojeto de Código Modelo de Processos Coletivos para os Países Ibero-Americanos e a legislação brasileira. Gênesis - Revista de Direito Processual Civil 31/11, jan.mar. 2004, p. 11. Em sentido contrário, GIDI, Antonio. Rumo a um Código de Processo Civil Coletivo: a codificação das ações coletivas no Brasil. Rio de Janeiro: Forense Universitária, 2008, p. 306.

${ }^{283}$ Cf. LEONEL, Ricardo de Barros. A causa petendi nas ações coletivas. In Causa de pedir e pedido no processo civil: questões polêmicas. CRUZ E TUCCI, José Rogério e BEDAQUE, José Roberto dos Santos (Coords.). São Paulo: Revista dos Tribunais, 2002.
} 
Isso explica a razão pela qual o presente trabalho é pautado nos elementos das demandas coletivas, ainda que seja para romper alguns paradigmas - até porque "a sociedade de massa exige do intérprete nova visão, sendo evidente a insuficiência dos instrumentos próprios de um momento em que o fenômeno dos conflitos de massa eram socialmente menos incidentes" $" 284$.

\section{III.4. Elemento subjetivo: irrelevância da identidade física do legitimado}

A irrelevância da identidade física da parte formal no pólo ativo das demandas coletivas conta com amplo embasamento na doutrina.

De início, é preciso ter em mente que, para fins de identificação de demandas, os elementos objetivos preponderam sobre o elemento subjetivo, quer no plano da jurisdição singular, quer no plano da jurisdição coletiva. CHIOVENDA já dizia que os elementos objetivos da demanda são aqueles que se referem à identificação do bem da vida de que tratam as ações objeto de confronto. Para o autor, o elemento subjetivo tem em vista apenas a pertinência ativa ou passiva desse bem ${ }^{285}$.

Na consagrada obra 'Ensaio sobre a litispendência no Direito Processual Civil', ARRUDA ALVIM já demonstrava a preponderância dos elementos objetivos sobre o subjetivo, para fins de identificação de demandas, reconhecendo que:

Deve-se partir do fim objetivado, o que nos leva ao exame da prestação jurisdicional que se deseja. Havendo identidade de prestações jurisdicionais - em dois ou mais pedidos - haverá identidade de ações. Deve-se advertir, contudo, que para haver identidade de ações - embora diversas as partes - impõe-se, necessariamente, que as partes diversas sejam igualmente legitimas processualmente ${ }^{286}$.

\footnotetext{
${ }^{284}$ RUFFOLO, Ugo. Interessi Collettivi o Difussi e Tutela Del Consumatore. Milão: Giuffrè, 1985, p.106. Apud GOMES JR., Luiz Manoel. Curso de Direito Processual Civil Coletivo. São Paulo: SRS, 2008, p. 195. ${ }^{285}$ CHIOVENDA, Giuseppe. Instituições..., op. cit., v. I, p. 355.

${ }^{286}$ ARRUDA ALVIM. Ensaio..., op. cit., v. II, p. 66 (g.n.).
} 
E conclui o autor: se podem pessoas diversas valer-se da mesma ação é porque elas têm legitimação concorrente, "isto é, mais de uma pessoa pode usar da mesma ação para idêntico fim. A que ajuizar a ação em primeiro lugar exclui a ação idêntica das demais, conquanto não haja identidade física"287.

Apesar de a obra ter sido escrita em 1970, ela se amolda perfeitamente à sistemática das ações coletivas, em que, por disposição expressa de lei, a legitimação para a propositura de ação em defesa dos interesses coletivos (lato sensu) é concorrente e disjuntiva. Vale dizer: mais de uma pessoa pode substituir a coletividade em juízo, e, entre elas, não há ordem de prioridade.

Não por outro motivo a doutrina dedicada ao estudo da tutela coletiva, quase que por unanimidade ${ }^{288}$, defende que a propositura de duas ou mais demandas por diferentes legitimados não obsta o reconhecimento de identidade de partes. $\mathrm{O}$ fundamento para tanto repousa na qualidade jurídica da parte, que deve preponderar sobre sua identidade física.

Como visto acima, a legitimação extraordinária permite que determinadas pessoas ingressem em juízo, em nome próprio, para defender direito alheio. Isso significa que, no caso da jurisdição coletiva, o interesse/direito 'feito valer' pertence à coletividade, que é a parte substancial da demanda, na condição de substituída.

Em sua clássica lição a respeito do tema, GRINOVER faz um comparativo entre a Ação Civil Pública contra ato de improbidade administrativa e a Ação Popular, enfatizando que: "Lá o parquet, aqui o cidadão, são sempre de qualquer modo substitutos processuais,

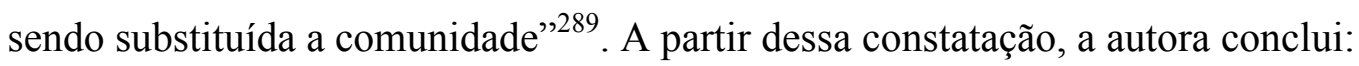

\footnotetext{
${ }^{287}$ ARRUDA ALVIM. Ensaio..., op. cit., v. II, p. 67 (g.n.).

${ }^{288}$ Nesse sentido: Rodolfo de Camargo MANCUSO, Ada Pellegrini GRINOVER, Antonio GIDI, Hugo Nigro MAZZILLI, Kazuo WATANABE, Teresa Arruda Alvim WAMBIER, Ricardo de Barros LEONEL, Luiz Guilherme MANINONI e Sérgio Cruz ARENHART, dentre tantos outros. Em sentido oposto, José dos Santos CARVALHO FILHO e Pedro da Silva DINAMARCO, para quem: "apenas quando o mesmo autor (parte formal) ajuizar duas ações coletivas com a mesma causa de pedir e mesmo pedido é que se estará caracterizada a litispendência" (In Competência, conexão e prevenção nas ações coletivas. In Ação Civil Pública após 20 anos: efetividade e desafios. MILARÉ, Édis (Coord.). São Paulo: Revista dos Tribunais, 2005, p. 513).

${ }^{289}$ GRINOVER, Ada Pellegrini. Uma nova modalidade de legitimação à ação popular. Possibilidade de conexão, continência e litispendência. In Ação Civil Pública - reminiscências e reflexões após 10 anos de aplicação. MILARÉ, Édis (Coord.). São Paulo: Revista dos Tribunais, 1995, p. 24.
} 
A diferença entre os legitimados não exclui a identidade de partes ativas, por serem todos substitutos processuais da coletividade. $\boldsymbol{E}$ esta $-\boldsymbol{a}$ substituída - que está em juízo, pelo portador de interesses, extraordinariamente legitimado pela Constituição e pela lei ${ }^{290}$.

De certa forma, a doutrina afasta a regra literal do CPC, para reconhecer a identidade de partes nas ações coletivas, conquanto diferentes os legitimados ativos. Tratando especificamente de ações coletivas, ARRUDA ALVIM sustenta que apesar de os legitimados não serem exatamente os mesmos, isso não impede que eles sejam considerados, juridicamente, a mesma parte, tendo em vista a idêntica função que exercem no processo, levando o mesmo conflito de interesses ao juízo e com fundamento na mesma causa de pedir. "Daí se falar, à luz dessas considerações, em litispendência entre duas ações coletivas, desde que se esteja em defesa do mesmo direito"291.

\section{Em reforço, VENTURI pondera que:}

A aferição da litispendência na tutela coletiva deve ser regida não pela análise de quem formalmente se apresenta como o autor das diversas demandas, mas sim pela qualificação jurídica de tal legitimação, vale dizer, indagando-se a que título estão as diferentes entidades autoras em juizo, deduzindo idênticas pretensões de tutela de direitos metaindividuais (mesmos pedidos e causas de pedir), quando, então, será possível afirmar serem idênticas as demandas coletivas ${ }^{292}$.

\footnotetext{
${ }^{290}$ GRINOVER, Ada Pellegrini. Uma nova modalidade..., op. cit., p. 25. Em reforço, MAZZILLI, Hugo Nigro salienta que "tanto o cidadão nas ações populares como os co-legitimados ativos nas ações civis públicas, todos eles agem por substituição processual em benefício da coletividade lesada" (In A defesa dos interesses difusos..., op. cit., p. 228).

${ }^{291}$ ARRUDA ALVIM. Código de Defesa do Consumidor Comentado. São Paulo: Revista dos Tribunais, 1995, p. 236. Apud ARRUDA ALVIM, Eduardo. Coisa julgada a litispendência no Anteprojeto de Código Brasileiro de Processos Coletivos. In Direito Processual Coletivo e o Anteprojeto de Código Brasileiro de Processos Coletivos. GRINOVER, Ada Pellegrini, MENDES, Aluisio Gonçalves de Castro e WATANABE, Kazuo (Coords.). São Paulo: Revista dos Tribunais, 2007, p. 188). No mesmo sentido, GIDI, Antonio entende que "para efeito de legitimidade, litispendência, efeitos da sentença e sua imutabilidade (...) as partes são consideradas as mesmas pelo direito positivo, muito embora, empiricamente, no mundo naturalístico, não o sejam" (In Coisa julgada..., op. cit., p. 219).

${ }^{292}$ VENTURI, Elton. Processo Civil Coletivo. São Paulo: Malheiros, 2007, p. 331, passim. Ainda no mesmo sentido, LEONEL, Ricardo de Barros pontua que "na identificação do autor (...) não se leva em conta a sua identidade física ou institucional, mas sim a identidade da respectiva condição jurídica" (In Manual..., op. cit., p. 229 - g.n.).
} 
Traçando um paralelo com o instituto da coisa julgada, MAZZILLI posiciona-se no sentido de que, em casos de ações propostas por diferentes co-legitimados, negar que haja litispendência é o mesmo que não admitir a formação da coisa julgada erga omnes ${ }^{293}$. Isto é, no caso de uma ação coletiva ser julgada improcedente, sem que seja por falta de prova, nenhum outro co-legitimado poderá intentar ação com a mesma causa de pedir e o mesmo pedido, pois sobre a matéria terá se formado imutabilidade erga omnes. Ou seja, o fato de a coisa julgada ser erga omnes significa que a sentença: (i) beneficia a todos em caso de procedência; e (ii) impede qualquer um de agir, em caso de improcedência - salvo por insuficiência de provas.

E faz sentido que seja assim. Caso a imutabilidade do julgado das ações coletivas não se estendesse a terceiros, haveria como resultado a multiplicação desnecessária de ações semelhantes, com o mesmo objetivo. Isso emperraria ainda mais o Judiciário, inviabilizando a prevenção ou reparação do dano, e daria causa a decisões contraditórias, comprometendo o já desgastado prestígio do Poder Judiciário brasileiro, o que leva GIDI a concluir que "perderiam, assim, a sua própria razão de ser as ações coletivas" "294.

\section{III.4.1. Peculiaridade: pólo passivo}

Enquanto a irrelevância da identidade física do legitimado ativo nas demandas coletivas parece estar suficientemente esclarecida, questão ainda pouco debatida diz respeito à identidade de partes no pólo passivo nas ações coletivas. Indo direto ao ponto: é possível falar em identidade de partes quando os réus de duas ou mais ações coletivas não forem os mesmos?

Em princípio, a resposta haveria de ser negativa. No entanto, é possível pensar em uma hipótese na qual a identidade do pólo passivo torna-se "secundária": o caso de dano ambiental causado por mais de um poluidor, assim entendido qualquer "a pessoa física ou jurídica, de direito público ou privado, responsável, direta ou indiretamente, por atividades

\footnotetext{
${ }^{293}$ MAZZILli, Hugo Nigro. A defesa dos interesses difusos..., op. cit., p. 227 e 230 . No mesmo sentido posiciona-se WAMBIER, Teresa Arruda Alvim por reconhecer que os institutos da coisa julgada e da litispendência assentem-se nos mesmos elementos (Litispendência em ações coletivas. In Processo Civil Coletivo. MAZZEI, Rodrigo e NOLASCO, Rita Dias (Coords.). São Paulo: Quartier Latin, 2005, p. 290).

${ }^{294}$ GIDI, Antonio. Coisa julgada..., op. cit., p. 60 (g.n.).
} 
causadoras de degradação ambiental" ${ }^{295}$. Tal hipótese não é rara, podendo-se citar, como exemplos, a contaminação de um rio por lançamento de efluentes de diversas empresas; a poluição do ar por conta de emissões atmosféricas provenientes de diversas fontes; a contaminação do solo em decorrência da má gestão de resíduos oriundos de diferentes geradores.

Em termos processuais, pode-se dizer que, nessas demandas ambientais, como a responsabilidade é solidária, isto é, cada 'poluidor' responde pela reparação integral do dano, as ações podem ser consideradas idênticas, ainda que os réus sejam diferentes, na medida em que ambas buscam a reparação integral do mesmo dano, causado conjuntamente por mais de uma pessoa. Não se está, com isso, admitindo que a coisa julgada atingirá quem não integrou o pólo passivo da demanda - tanto que o réu terá ação de regresso contra os demais responsáveis. Está-se apenas admitindo que, nesta hipótese, poderá haver identidade de ações, conquanto diferentes os legitimados passivos, uma vez que cada réu responderá pela integralidade da obrigação, no lugar dos demais responsáveis.

Nesse sentido, GRINOVER admite a possibilidade de litispendência mesmo quando haja apenas identidade parcial do pólo passivo. É o que a autora chama de “aparente diferença de partes passivas", que, por si só, não é suficiente para afastar a identidade de ações, tendo em vista que "a pedra de toque para o exame dos nexos entre as ações é dada pela análise do pedido e da causa de pedir "296. Também RODRIGUES reconhece essa possibilidade ao analisar os institutos da conexão, continência e litispendência nas ações civis públicas ambientais, dando como "ultrapassada a problematização acerca da concomitância de demandas coletivas propostas por representantes adequados distintos ou defendidas por partes passivas distintas, porém solidárias ${ }^{297}$.

\footnotetext{
${ }^{295}$ Conforme definição da Lei 6.938/81, art. $3^{\circ}$, IV.

${ }^{296}$ GRINOVER, Ada Pellegrini. Uma nova modalidade de legitimação à ação popular. Possibilidade de conexão, continência e litispendência. In Ação Civil Pública - reminiscências e reflexões após 10 anos de aplicação. MILARÉ, Édis (Coord.). São Paulo: Revista dos Tribunais, 1995, p. 25/26.

${ }^{297}$ RODRIGUES, Marcelo Abelha. Ação Civil Pública..., op. cit., p. 145 (g.n.).
} 
Ainda neste tópico, vale uma breve nota quanto ao regime diferenciado da coisa julgada nas ações coletivas e a sua não-aplicação ao pólo passivo. De fato, aquele que não foi parte no processo, na condição de réu, não pode sofrer os efeitos negativos do julgado, sob pena de violar a garantia constitucional do devido processo legal, em especial, o direito à ampla defesa. Essa premissa continua válida mesmo em sede de ações coletivas.

O exemplo de uma sentença proferida, em sede de ação coletiva, contra determinada montadora de veículos, um banco ou uma empresa de plano de saúde ilustra tal situação. Os limites subjetivos da coisa julgada desta decisão só poderão ser ampliados (erga omnes) quanto ao pólo ativo, para atingir aqueles que, embora não tenham sido parte formal no processo, estão substituídos pelo legitimado ativo. A decisão não poderá, contudo, atingir outras montadoras, bancos ou empresas de plano de saúde que não tenham sido incluídas no pólo passivo da ação, tendo em vista que, nesse caso, elas não terão sido nem parte formal, nem parte substancial no processo.

Daí GIDI ressalvar que apesar de a coisa julgada nas ações coletivas atingir quem não foi parte no processo (efeito erga omnes ou ultra partes), apenas os consumidores podem ser beneficiados com a sentença coletiva favorável. Em outras palavras, os fornecedores não citados como réus na ação coletiva não podem ser por ela prejudicados $^{298}$.

De fato, a coisa julgada passiva 'erga omnes' e a Ação Coletiva Passiva 299 (defendant class action) ainda não existem em nosso sistema, tratando-se, no entanto, de figuras previstas no ANTEProjeto de Código De Processo Civil Coletivo da USP ${ }^{300}$

\footnotetext{
${ }^{298}$ GIDI, Antonio. Coisa julgada..., op. cit., p. 184.

${ }^{299}$ A respeito do tema, vide VIOLIN, Jordão. Ação Coletiva Passiva. Salvador: Podium, 2008.

${ }^{300}$ Sobre o tema, dispõem os artigos 36, 37 e 38, in verbis:

"Art. 36. Ações contra o grupo, categoria ou classe - Qualquer espécie de ação pode ser proposta contra uma coletividade organizada, mesmo sem personalidade jurídica, desde que apresente representatividade adequada (artigo 19, I, "a", "b" e "c"), se trate de tutela de interesses ou direitos difusos e coletivos $\left(\right.$ artigo $3^{\circ}$ ) e a tutela se revista de interesse social.

Parágrafo único. O Ministério Público e os órgãos públicos legitimados à ação coletiva ativa (art. 19, incisos III, IV, V e VI e VII deste Código) não poderão ser considerados representantes adequados da coletividade, ressalvadas as entidades sindicais.

Art. 37. Coisa julgada passiva - A coisa julgada atuará erga omnes, vinculando os membros do grupo, categoria ou classe e aplicando-se ao caso as disposições do artigo 12 deste Código, no que dizem respeito aos interesses ou direitos transindividuais.

Art. 38. Aplicação complementar às ações coletivas passivas - Aplica-se complementarmente às ações coletivas passivas o disposto no Capítulo I deste Código, no que não for incompatível.
} 
(até o momento, sem correspondência na PROPOSTA DO MINISTÉRIO DA JUSTIÇA/SECRETARIA DE REFORMA DO JUDICIÁRIO) ${ }^{301}$.

A Ação Coletiva Passiva (defendant class action) a despeito de um regramento específico no direito positivo brasileiro, já vem sendo utilizada num ou noutro caso, como ocorre, por exemplo, nos casos de demandas propostas em razão de movimentos grevistas contra associações ou sindicatos ${ }^{302}$. Outro exemplo bastante citado pela doutrina está relacionado às torcidas organizadas de futebol, que poderiam ser acionadas em nome da respectiva categoria ou classe, de modo que todos os torcedores a ela associados sejam abrangidos pela decisão.

A hipótese mais aceita de Ação Coletiva Passiva são as chamadas ações duplamente coletivas, que têm lugar quando há um conflito entre massas. Traçando um paralelo com a garantia do acesso à justiça, VIOLIN assevera que "a ação coletiva passiva amplia a tutela de conflitos de massas (...), [na medida em que] alarga o campo de atuação do Poder Judiciário na efetivação dos direitos coletivos"303.

Com efeito, não há como negar que a alta conflituosidade interna, característica dos interesses difusos, pode dar margem a que um interesse se oponha a outro, ambos igualmente dignos de tutela coletiva. É o caso, por exemplo, da instalação de uma usina de compostagem de resíduos domiciliares, em que se podem imaginar, pelo menos, duas posições: (i) de um lado, haverá quem seja a favor da implantação do empreendimento, como forma de solucionar o problema do lixo urbano, que afeta toda a coletividade; (ii) de outro lado, haverá quem se oponha à implantação da usina, tendo em vista a geração de odor, a propagação de vetores (insetos transmissores de doenças) e o aumento do tráfego de caminhões. Dependendo de quem figure como autor ou como réu, estar-se-á diante de

Parágrafo único. As disposições relativas a custas e honorários, previstas no artigo 16 e seus parágrafos, serão invertidas, para beneficiar o grupo, categoria ou classe que figurar no pólo passivo da demanda".

${ }^{301} \mathrm{~A}$ única referência que há, no texto, à possibilidade de o legitimado coletivo figurar no pólo passivo está relacionada à Ação Rescisória, que vem tratada da seguinte forma: "Art. 45. A ação rescisória objetivando desconstituir sentença ou acórdão de ação coletiva deverá ser ajuizada em face do legitimado coletivo que tenha ocupado o pólo ativo originariamente, podendo os demais co-legitimados atuarem como assistentes. $\mathrm{Na}$ sua impossibilidade, a ação rescisória coletiva será ajuizada em face do Ministério Público".

${ }^{302}$ Nesse sentido, VIOLIN, Jordão cita como exemplos a ação ajuizada pela União em face da Federação nacional dos Policiais Federais e do Sindicato dos Policiais Federais no Distrito Federal, em razão da greve nacional da categoria, e a ação ajuizada pelo Estado do Rio de Janeiro em face da Associação dos Defensores Públicos, em razão de greve reputada ilegal e abusiva (Ação Coletiva .., op. cit., p. 95).

${ }^{303}$ VIOLIN, Jordão. Ibidem, p. 112. 
uma Ação Coletiva "normal” ou de uma Ação Coletiva Passiva. Daí se dizer que ambas as ações são lados opostos de uma mesma moeda.

A maior dificuldade relacionada às ações coletivas passivas está, sem dúvida, na legitimação passiva ad causam: quem será o substituto processual da coletividade? A solução para o problema, porém, está no controle judicial da representatividade adequada. Havendo um legitimado que represente adequadamente os interesses da classe, nada impede que a coletividade organizada seja ré em uma ação.

Quanto à possibilidade de a Ação Coletiva Passiva ser utilizada contra os interesses coletivos (lato sensu), GIDI adverte - pautando-se no sistema norte-americano - que um potencial réu não pode dela se utilizar para obter uma decisão que declare, v.g., que seu produto não causou danos à coletividade (sentença declaratória negativa). Para o autor, esta hipótese não configura uma ação coletiva passiva, mas, sim, uma "ação coletiva ativa iniciada pelo réu"304.

No que tange ao objeto de estudo, i.e., a relação entre demandas coletivas, importa ressaltar que, em princípio, nada obsta haver identidade (rectius: litispendência) entre uma Ação Coletiva "normal" e uma Ação Coletiva Passiva. Basta, para tanto, que se considerem os elementos objetivos de ambos os processos, independentemente de quem figure como autor ou como réu. Se o thema decidendum for o mesmo, as ações serão a mesma, comportando uma única decisão. No exemplo acima citado, o thema decidendum é a instalação de uma usina de compostagem, questão que só comporta uma solução: ou a usina será permitida ou será negada. Nessa esteira, WAMBIER assevera que nas ações coletivas em que o objeto e a causa de pedir forem os mesmos, coincidirão, necessariamente, os titulares dos direitos. Deste modo, dentre os elementos de que trata a doutrina clássica, a apuração da litispendência entre ações coletivas deve considerar apenas o objeto e a causa de pedir ${ }^{305}$.

\footnotetext{
${ }^{304}$ GIDI, Antonio. A class action como instrumento de tutela coletiva dos direitos. São Paulo: Revista dos Tribunais, 2007, p. 392.

${ }^{305}$ WAMBIER, Teresa Arruda Alvim. Litispendência em ações coletivas. In Tutela Coletiva - 20 anos da Lei da Ação Civil Pública e do Fundo de Defesa de Direitos Difusos e 15 anos do Código de Defesa do Consumidor. LUCON, Paulo Henrique dos Santos (Coord.). São Paulo: Atlas, 2006, p. 273.
} 
Por fim, com certa dose de inventiviness, é ainda possível traçar um paralelo entre as Ações Coletivas “normal” e Passiva e as Ações Dúplices e a Reconvenção. A respeito do tema, BARBOSA MOREIRA já escreveu que "a reconvenção e a ação primitiva não necessitam ser conexas no sentido do enunciado do art. 103"306.

A bem ver, portanto, a Ação Coletiva Passiva (assim que passar a existir de lege lata em nosso sistema) também deverá ser considerada na relação com outras demandas coletivas.

\section{III.5. Elementos objetivos das demandas coletivas ${ }^{307}$}

Como visto, os elementos objetivos preponderam sobre o elemento subjetivo para fins de identificação de demandas. Como salienta GRINOVER, é preciso analisar o objeto da ação, ou seja, o pedido, levando-se em conta a causa de pedir, para aferir se há identidade total ou parcial de ações, impedindo a duplicidade ou a desarmonia de julgados $^{308}$. Isso porque, repetindo o ensinamento de MESQUITA, “causa petendi e petitum, intimamente ligados (...) são por excelência os elementos identificadores do objeto do processo"309.

Nesta esteira, WATANABE ressalta a importância de identificarem-se demandas coletivas por meio do isolamento de seus elementos objetivos. Para o autor, tais dados não apenas fixam a amplitude da demanda, como, também, indicam se no caso concreto ocorre mera conexidade entre as diversas demandas coletivas ou se é caso de litispendência a obstar o prosseguimento das ações posteriores ${ }^{310}$.

\footnotetext{
${ }^{306}$ BARBOSA MOREIRA, José Carlos. A conexão de causas como pressuposto da reconvenção. São Paulo: Saraiva, 1979, p. 124.

307 A respeito do tema, vide GABBAY, Daniela. Processo coletivo e elementos objetivos da demanda. Dissertação (Mestrado). 23.10.2007. Orientador: Prof. Dr. Carlos Alberto de Salles. São Paulo, 2007. Faculdade de Direito, Universidade de São Paulo.

${ }^{308}$ GRINOVER, Ada Pellegrini. Código Brasileiro de Defesa..., op. cit., p. 939 e ss.

${ }^{309}$ MESQUITA, José Ignácio Botelho de. A causa petendi nas ações reivindicatórias. Teses, Estudos e Pareceres de Processo Civil. São Paulo: Revista dos Tribunais, 2005, p. 140.

310 WATANABE, Kazuo. Demandas coletivas e os problemas emergentes da práxis forense. Revista de Processo, n. 67, São Paulo: Revista dos Tribunais, jul./set. 1992, p. 18.
} 
Ao tratar dos elementos objetivos, MANCUSO salienta que, no plano da jurisdição coletiva,

O interesse judicializado é indivisível e pertine a sujeitos indeterminados, fazendo com que a causa substancial do conflito e suas peculiaridades acabem de envolta com o que constitui o pedido, e, pois, o objeto da lide, tomado esse num sentido amplo ou holístico. (...) Essa estreita $e$ praticamente incindível conexão entre causa de pedir e pedido parece mesmo ser uma peculiaridade dos processos coletivos ${ }^{311}$.

Pois bem. Com foco nos elementos objetivos, não se pode perder de vista que no plano da jurisdição coletiva, a operação de identificação de demandas não pode ser tão rígida a ponto de exigir-se a identidade absoluta de partes, pedido e causa de pedir - tendo lugar a adoção de critérios subsidiários, como a identidade do bem jurídico coletivo.

Esse é o sentir de GRINOVER, para quem o conceito rígido de pedido e causa de pedir, próprio do processo individual, aplicado ao processo coletivo, "tem dificultado, no Brasil, a reunião de processos, provocando a condução fragmentária de demandas, com decisões contraditórias" ${ }^{, 312}$. Por esse motivo,

$\mathrm{O}$ que se tem em mente, para a identificação dos fenômenos acima indicados, não é o pedido, mas o bem jurídico a ser protegido; a causa de pedir é interpretada extensivamente; e a diferença de legitimados ativos não constitui empecilho para o reconhecimento da identidade dos sujeitos. Isso significa que as causas são reunidas com maior facilidade e que a litispendência tem um âmbito maior de aplicação ${ }^{313}$.

\footnotetext{
${ }^{311}$ MANCUSO, Rodolfo de Camargo. Jurisdição coletiva..., op. cit., p. 102/103 (g.n.).

312 GRINOVER, Ada Pellegrini. Direito Processual Coletivo. In Tutela Coletiva: 20 anos da Ação Civil Pública e Fundo de Defesa de Direitos Difusos, 15 anos do Código de Defesa do Consumidor. LUCON, Paulo Henrique dos Santos (Coord. ). São Paulo: Atlas, 2006, p. 307.

${ }^{313}$ GRINOVER, Ada Pellegrini. Ibidem, p. $305 / 306$ (g.n.).
} 
Por igual, GIDI sustenta que a litispendência nas ações coletivas só depende de uma 'interpretação inteligente' das normas do CPC, asseverando que duas demandas coletivas são idênticas (rectius: são a mesma) quando têm por objeto controvérsia sobre o mesmo bem jurídico ${ }^{314}$.

Com isso em mente, é possível passar à análise dos elementos objetivos das demandas coletivas, mais especificamente, da causa de pedir remota e do pedido mediato. Para tanto, faz-se necessário retomar uma premissa definida no Capítulo I, qual seja: no presente trabalho, a causa de pedir remota refere-se aos fatos constitutivos do direito alegado, isto é, aos fatos 'históricos' e ao fato violador, ambos denominados 'acontecimentos da vida'; ao passo que a causa de pedir próxima informa apenas a repercussão jurídica destes fatos, o efeito que o ordenamento jurídico lhes atribui ${ }^{315}$.

\section{III.5.1. Foco no núcleo essencial / thema decidendum / bem jurídico coletivo / resultado prático visado pelos processos}

Com o objetivo claro de nortear a leitura dos parágrafos seguintes, este subitem inicia-se pela sua conclusão (a qual não será surpresa para o leitor atento):

Não é necessário que a segunda demanda seja rigorosamente idêntica à primeira para que ela seja inadmissivel em razão da litispendência. Deve-se atentar para o resultado prático e externo que o processo é apto a produzir ${ }^{316}$.

\footnotetext{
314 GIDI, Antonio. Rumo a um Código de Processo Civil Coletivo: a codificação das ações coletivas no Brasil. Rio de Janeiro: Forense Universitária, 2008, p. 306, passim (g.n.).

${ }^{315}$ No caso das ações ambientais, dada a responsabilidade civil objetiva, os fatos constitutivos do direito alegado cingem-se ao dano e ao nexo de causalidade, ao passo que o fundamento jurídico do pedido repousa, por exemplo, no direito ao meio ambiente ecologicamente equilibrado (art. 225 da Constituição Federal) e na obrigação do poluidor de reparar os danos causados ao meio ambiente independentemente de culpa (art. 14, $\S 1^{\circ}$, da Lei $6.938 / 81$ ).

316 DINAMARCO, Pedro Silva. Competência, conexão e prevenção nas ações coletivas. In Ação Civil Pública após 20 anos: efetividade e desafios. MILARÉ, Édis (Coord.). São Paulo: Revista dos Tribunais, 2005, p. 513.
} 
O primeiro passo para chegar a essa conclusão é aprofundar-se, justamente, no exame da relação jurídica deduzida em juízo e nas conseqüências jurídicas dos pedidos de ambas as ações coletivas. A adoção de uma visão mais ampla e menos formalista conduz à identificação das demandas coletivas não por meio da literalidade do pedido e da causa de pedir, mas pela análise do núcleo essencial, do thema decidendum, do bem jurídico coletivo, do resultado prático visado pelas demandas.

Nesse sentido, DINAMARCO ressalta que mais importante do que identificar os elementos da ação é saber o resultado prático visado pelo processo:

A chamada teoria das três eadem (mesmas partes, mesma causa petendi $\mathrm{e}$ mesmo petitum), conquanto muito prestigiosa e realmente útil, não é suficiente em si mesma para delimitar com precisão o âmbito de incidência do impedimento causado pela litispendência. Considerando o objetivo do instituto (evitar o bis in idem), o que importa é evitar dois processos instaurados com o fim de produzir o mesmo resultado prático. Por isso, impõe-se a extinção do segundo processo sempre que o mesmo resultado seja postulado pelos mesmos sujeitos $(\ldots)^{317}$.

Valendo-se do exemplo das ações de controle de constitucionalidade, MANCUSO demonstra a complexidade decorrente da concomitância entre duas ações coletivas, consignando que não se pode conceber mais de um pronunciamento do Supremo Tribunal Federal sobre um mesmo contencioso objetivo de constitucionalidade: ou o ato normativo é ou não é constitucional. Nessa linha, "fica evidente a nenhuma utilidade de uma segunda ação direta de inconstitucionalidade com igual finalidade ${ }^{\text {,318. }}$.

Note-se que o autor utiliza a expressão igual 'finalidade', em vez de igual 'pedido'. Isso reforça a idéia de que o que deve nortear a operação de identificação de demandas coletivas não é, necessariamente, os tria eadem, mas, antes, o próprio núcleo essencial das demandas, identificado pela relação jurídica substancial que as originou.

${ }^{317}$ DINAMARCO, Cândido Rangel. Instituições..., op. cit., p. 62 (g.n.).

${ }^{318}$ Cf. MANCUSO, Rodolfo de Camargo. A concomitância entre ações de natureza coletiva. In Direito Processual Coletivo e o Anteprojeto de Código Brasileiro de Processos Coletivos. GRINOVER, Ada Pellegrini, MENDES, Aluisio Gonçalves de Castro e WATANABE, Kazuo (Coord.). São Paulo: Revista dos Tribunais, 2007, p. 164 (g.n.). 
A identidade da relação substancial - em que pese a dificuldade de conceituação - pode ser entendida como "aquela integrante da mesma contextura existencial (tempo, local, circunstâncias concretas dos atos e fatos que deram margem à lesão de direitos)"319.

Não há como negar, pois, a importância dos fatos na identificação da relação jurídica substancial e, por conseguinte, do núcleo essencial das demandas coletivas. Embora pareça contraditório dizer isso, tendo em vista a teoria da identidade da relação jurídica aproximar-se mais da teoria da individuação do que da teoria da substanciação, é certo que o estudo da relação entre demandas coletivas não pode prender-se a posições extremadas.

Desta feita, é possível, em uma abordagem acadêmica, apropriar-se de aspectos provenientes das duas teorias, desde que, juntas, elas atendam às necessidades e às peculiaridades dos processos coletivos. Até porque "a validade da elaboração científica encontra-se, justamente, na sua utilidade e adequação para a solução de problemas concretos, que constitui seu verdadeiro banco de provas" ${ }^{320}$. E, como reconhece LEONEL, o grande problema das teorias extremadas é a sua "relativa aptidão para o equacionamento de dúvidas pragmáticas, inerentes à sua aplicação, associada ao equívoco na própria concepção"321.

Assim, ao mesmo tempo em que se propõe a adoção subsidiária da teoria da identidade da relação jurídica, ressalta-se a importância dos acontecimentos da vida para o fim de identificarem-se ações coletivas. Ao operador do direito cabe atentar tanto para a relação jurídica material que está por trás das demandas, quanto para os 'fatos históricos' e o 'fato violador' do direito coletivo (causa de pedir remota) que originaram a sua propositura.

\footnotetext{
319 LUCON, Paulo Henrique dos Santos, GABBAY, Daniela Monteiro, ALVES, Rafael Francisco e ANDRADE, Tathyana Chaves de. Interpretação do pedido e da causa de pedir nas demandas coletivas (conexão, continência e litispendência). In Tutela Coletiva - 20 anos da Lei da Ação Civil Pública e do Fundo de Defesa de Direitos Difusos e 15 anos do Código de Defesa do Consumidor. LUCON, Paulo Henrique dos Santos (Coord.). São Paulo: Atlas, 2006, p. 195/196, citando LEONEL, Ricardo de Barros. A causa petendi nas ações coletivas. In Causa de pedir e pedido no processo civil. CRUZ E TUCCI, José Rogério e BEDAQUE, José Roberto dos Santos (Coords.). São Paulo: Revista dos Tribunais, 2002, p. $163 / 168$.

${ }^{320}$ LEONEL, Ricardo de Barros. Causa de pedir e pedido: o direito superveniente. Op. cit., p. 84.

${ }^{321}$ Idem, ibidem, p. 84.
} 
Nessa linha de raciocínio, merece destaque o conceito de interesses difusos, coletivos e individuais homogêneos, definido pelo artigo 81, parágrafo único, da Lei n. 8.078/90, que 'privilegia' os acontecimentos da vida, conforme verbis:

Art. 81. A defesa dos interesses e direitos dos consumidores e das vítimas poderá ser exercida em juízo individualmente, ou a título coletivo.

Parágrafo único. A defesa coletiva será exercida quando se tratar de:

I - interesses ou direitos difusos, assim entendidos, para efeitos deste Código, os transindividuais, de natureza indivisível, de que sejam titulares pessoas indeterminadas e ligadas por circunstâncias de fato;

II - interesses ou direitos coletivos, assim entendidos, para efeitos deste Código, os transindividuais, de natureza indivisível de que seja titular grupo, categoria ou classe de pessoas ligadas entre si ou com a parte contrária por uma relação jurídica base;

III - interesses ou direitos individuais homogêneos, assim entendidos os decorrentes de origem comum (g.n.).

A bem ver, o CDC adotou três critérios básicos para definir e distinguir os interesses difusos, coletivos e individuais homogêneos: o critério subjetivo (titularidade do direito material), o critério objetivo (divisibilidade do direito material) e o critério de origem (origem do direito material) ${ }^{322}$. No que tange ao aspecto origem, a lei privilegiou (i) as circunstâncias de fato, como elemento essencial dos interesses difusos; (ii) a existência de uma relação jurídica base, como elemento essencial dos interesses coletivos em sentido estrito; e (iii) a existência de fatos de origem comum, como elemento essencial dos interesses individuais homogêneos. As 'circunstâncias de fato' (que englobam a 'origem comum ${ }^{323}$ ) e a 'relação jurídica base' são, justamente, os elementos que compõem a causa de pedir e, também, auxiliam a identificar a relação jurídica substancial.

\footnotetext{
${ }^{322}$ Cf. GIDI, Antonio. Coisa julgada..., op. cit., p. 22.

${ }^{323}$ Nesse sentido, GIDI defende que sob o aspecto origem, "não há como distinguir os direitos difusos dos direitos individuais homogêneos, pois a 'origem comum' que caracteriza os direitos individuais homogêneos é nada mais nada menos que as mesmas 'circunstâncias de fato' que ligam as pessoas que compõem a comunidade titular do direito difuso" (Ibidem, p. 24). Em sentido contrário, entendendo que, nesse aspecto, os direitos individuais homogêneos aproximam-se dos direitos coletivos, MAZZILLI, Hugo Nigro (Ação Civil Pública. Livro de Estudos Jurídicos. Rio de Janeiro: Instituto de Estudos Jurídicos, 1992, 6:97-8).
} 
Se, na essência, os interesses metaindividuais se definem e se identificam pelos acontecimentos da vida (no sentido de 'circunstâncias de fato' / 'relação jurídica base') por que não se adotar o mesmo critério processualmente? Para tanto, basta que, no confronto entre duas ações coletivas, a atenção do julgador esteja voltada não à literalidade dos elementos parte, pedido e causa de pedir, mas, sim, à identidade de circunstâncias materiais, à correlação entre as situações concretas da vida tratadas em ambas as demandas.

Daí a proposta de CRUZ E TUCCI e LEONEL, para quem o equacionamento de questões afetas à coisa julgada, muitas vezes, requer a adoção dos critérios da relação jurídica material, da relação substancial, do evento da vida, ou dos fatos jurígenos em sentido amplo, os quais se prestam, inclusive, à ampliação subjetiva dos efeitos da coisa julgada $^{324}$. Mais do que adotar um conceito meramente estrito e jurídico da relação jurídica de direito material, LEONEL sugere adotar uma visão mais abrangente da relação, avaliando, em um enfoque mais elástico, a existência ou não de uma identidade de circunstâncias materiais (ex: avaliar se o dano ambiental coletivo e o dano individual ocorreram no mesmo contexto dos atos que ocasionaram a lesão, no mesmo local, na mesma circunstância temporal) $)^{325}$.

A bem ver, deve-se atentar para o núcleo essencial das ações coletivas, o qual se revela, primeiro, pelos acontecimentos da vida que levaram os legitimados extraordinários a agir processualmente (v.g., a transposição do rio São Francisco; o licenciamento ambiental de determinado empreendimento causador de significativo impacto; a contaminação de um curso d'água ou de um lençol freático; a destruição de um certo bem tombado), e, segundo, pelo resultado prático visado pelas demandas.

A esse respeito, a Súmula n. 01 do Conselho Superior do Ministério Público do Estado de São Paulo estabelece que "se os mesmos fatos investigados no inquérito civil foram objeto de ação popular julgada improcedente pelo mérito e não por falta de provas, o caso é de arquivamento do procedimento instaurado" (g.n.). Em adição, diferentes julgados firmaram que: "há litispendência se a finalidade da ação popular é a mesma da ação civil

${ }^{324}$ TUCCI, José Rogério Cruz e. A causa petendi..., op. cit., p. 181. Apud LEONEL, Ricardo de Barros. A causa petendi nas ações coletivas. In Causa de pedir e pedido no processo civil. CRUZ E TUCCI, José Rogério e BEDAQUE, José Roberto dos Santos (Coords.). São Paulo: Revista dos Tribunais, 2002, p. 177.

${ }^{325}$ LEONEL, Ricardo de Barros. Ibidem. p. 164/165 e 169. 
pública, vez que ambas se destinam a anular os mesmos atos tidos como ilegais"326; e "a existência de ação civil pública já julgada ocasiona a falta de interesse processual do autor de ação popular que pretende o mesmo resultado jurídico obtido na ação anterior" ${ }^{\text {} 327 . ~}$

Tanto a Súmula quanto os julgados acima citados têm a mesma razão de ser: impedir que uma situação de fato idêntica, submetida a uma mesma disciplina jurídica, receba tratamentos diferenciados, ou seja, com decisões judiciais divergentes, em alguns $\operatorname{casos}^{328}$.

\section{III.5.2. Interpretação extensiva da causa de pedir remota e do pedido mediato}

Para chegar-se ao núcleo essencial da demanda, ao thema decidendum, ao bem jurídico coletivo, ao resultado prático visado pela demanda, é preciso flexibilizar, também, a forma de interpretar a causa de pedir remota e o pedido mediato. Para saber o exato alcance de uma demanda coletiva - e, então, confrontá-la com as demais -, o juiz, muitas vezes, não poderá ater-se à literalidade da petição inicial, devendo perquirir o bem jurídico tutelado pelo autor, ainda que, para tanto, tenha que interpretar extensivamente a causa de pedir remota e o pedido mediato.

Esse é o sentir de LUCON et al., para quem uma das principais diferenças entre os regimes jurídicos aplicáveis à jurisdição singular e à jurisdição coletiva reside na necessidade de uma interpretação extensiva do pedido e da causa de pedir, o que se justifica pelas peculiaridades do bem jurídico coletivo ${ }^{329}$. Para chegar a tal conclusão, os autores partem de três premissas.

\footnotetext{
${ }^{326}$ TJPR, 3 ${ }^{\text {a }}$ Câm. Cív., ApCív 79636-7, rel. Des. Jesus Serrão, j. 09.02.2000.

327 Cf. TJSP, 7 ${ }^{a}$ Câm. Direito Público, ApCív 153.521/8-00, rel. Des. Torres de Carvalho, j. 18.12.2000, citado por WAMBIER, Teresa Arruda Alvim. Litispendência em ações coletivas. In Processo Civil Coletivo. MAZZEI, Rodrigo e NOLASCO, Rita Dias (Coords.). São Paulo: Quartier Latin, 2005, p. 292/293.

${ }^{328}$ Cf. GOMES JR, Luiz Manoel. Curso de Direito Processual Civil Coletivo. São Paulo: SRS, 2008, p. 186, passim (g.n.).

329 LUCON, Paulo Henrique dos Santos, GABBAY, Daniela Monteiro, ALVES, Rafael Francisco e ANDRADE, Tathyana Chaves de. Interpretação do pedido e da causa de pedir nas demandas coletivas (conexão, continência e litispendência). In Tutela Coletiva - 20 anos da Lei da Ação Civil Pública e do Fundo de Defesa de Direitos Difusos e 15 anos do Código de Defesa do Consumidor. LUCON, Paulo Henrique dos Santos (Coord.). São Paulo: Atlas, 2006, p. 184/199.
} 
A primeira é a de que não há, no microssistema processual coletivo, norma explícita sobre os institutos da conexão, continência e litispendência ${ }^{330}$, o que torna necessário socorrer-se do CPC (mais especificamente, dos artigos 293, 103, 104, 105, 106, 219 e 301). Todavia, essa "importação" deve ser feita de modo a compatibilizar os institutos clássicos do $\mathrm{CPC}$ às necessidades e às peculiaridades das ações coletivas, o que pode dar-se (i) de lege ferenda, por meio de inovação legislativa, consubstanciada nos Anteprojetos de Código de Processos Coletivos atualmente em discussão ${ }^{331}$; ou (ii) de lege lata, a partir de uma nova perspectiva interpretativa dos institutos existentes, que conduza ao melhor resultado para a coletividade. Neste ponto, vale lembrar que a interpretação tem como objetivo garantir a continuidade da lei e sua harmonização com as demais normas do sistema, e a interpretação extensiva é aquela que vai além do significado textual da norma jurídica, buscando seu conteúdo teleológico e finalístico.

A segunda premissa é a de que o bem jurídico coletivo, por dizer respeito a interesses de determinados grupos ou corpos intermediários é, por natureza, indisponivel $^{332}$.

Finalmente, a terceira premissa é a de que, na transposição extraprocessual para o processo, a pretensão deduzida em juízo não coincide com a totalidade do conflito existente na realidade social. Com efeito, não raras vezes, o autor de demandas individuais narra os fatos $\mathrm{e}$ formula o pedido de maneira incompleta - consciente ou inconscientemente -, deixando de exercer a tutela integral de seus direitos, seja porque o desconhece toda a realidade emergente dos fatos, seja porque optou por dispor de parcela do seu direito. Ocorre, porém, que, nas ações coletivas, o interesse é indisponível, de forma que não pode o autor abrir mão de parcela do direito, no recorte do seu pedido. Em que pese isso, casos há em que o legitimado ativo sequer conhece toda a extensão do dano, no

\footnotetext{
${ }^{330}$ Salvo o art. 104, CDC (que trata de litispendência - e não conexão nem continência - entre ações coletivas e individuais, mas não entre ações coletivas) e os artigos $5^{\circ}, \S 3^{\circ}$, da Lei da Ação Popular e $2^{\circ}$, parágrafo único, da Lei da Ação Civil Pública (que abordam a conexão entre ações coletivas, mas não a litispendência).

331 Além das duas propostas analisadas no presente trabalho (ANTEPROJETO DA USP e PROPOSTA DE AlteraÇão da Lei da AÇÃo Civil Pública do Ministério da JustiÇA/SECretaria de Reforma dO JUDICIÁRIO), importa salientar que ainda existem outras duas propostas sendo discutidas no cenário nacional - além do Código-Modelo de Processos Coletivos para a Ibero-América. São elas: o ANTEPROJETO DE ANTONIO GIDI e o ANTEPROJETO DAS UNIVERSIDADES DO ESTADO DO RIO DE JANEIRO (UERJ) E ESTÁCIO DE SÁ (UNESA).

${ }^{332}$ Nesse sentido, CAPPELLETTI, Mauro. Formações sociais e interesses coletivos diante da Justiça Civil. Revista de Processo n. 5, São Paulo: Revista dos Tribunais, 1977; e MANCUSO, Rodolfo de Camargo. Interesses difusos..., op. cit..
} 
momento da propositura da ação, e acaba fazendo um pedido 'menor' do que deveria. Nesses casos, a disposição indevida feita pelo autor poderia ser corrigida pelo próprio juiz, na tarefa de interpretar, extensivamente, o pedido, de modo a se atingir a proteção integral do bem jurídico coletivo.

Traçando um paralelo com as ações cautelares, em que o juiz tem o poder geral de cautela (inclusive, ex officio), LUCON et al. destacam a lição de NEVES, segundo a qual "a limitação objetiva e subjetiva do conflito de interesses, em toda a sua abrangência, é que determina a limitação da ação cautelar" ${ }^{333}$. Ou seja, mais vale o que está no mundo real do que o recorte formulado pelo autor na petição inicial.

Logicamente, essa "correção", pela via da interpretação extensiva do pedido, deve observar os princípios do contraditório e da ampla defesa.

E concluem os autores, afirmando que o artigo 293 do CPC não é aplicável subsidiariamente aos processos coletivos, devendo prevalecer a interpretação extensiva, tanto do pedido, quanto da causa de pedir. Somente desta maneira restará preservada a indisponibilidade deste direito ${ }^{334}$.

Nesse contexto, ao interpretar extensivamente o pedido, o juiz promoverá a adequação da pretensão deduzida em juízo ao bem jurídico subjacente ${ }^{335}$. Aqui, por exemplo, a teoria da identidade da relação jurídica poderia ser aplicada, subsidiariamente, como parâmetro/limite ao juiz para a interpretação dos elementos objetivos da demanda. Em outras palavras: o juiz poderá interpretar extensivamente a causa de pedir e o pedido nas ações coletivas, desde que não extrapole a relação jurídica substancial levada a juízo.

Em reforço a essa idéia, MANCUSO demonstrou que a adstrição do julgado ao pedido (princípio dispositivo), tão marcante no sistema tradicional do processo civil ${ }^{336}$ "vem sofrendo refrações e temperamentos, ao influxo do crescente acesso à Justiça dos

${ }^{333}$ NEVES, Celso. Estrutura fundamental do processo civil: tutela jurídica processual, ação, processo e procedimento. Rio de Janeiro: Forense, 1997, p. 145. Apud LUCON et al. Interpretação do pedido..., op. cit., p. 189.

${ }^{334}$ LUCON et al., Interpretação do pedido..., op. cit., p. 189.

335 Idem, ibidem, p. 191.

${ }^{336}$ No sentido de que não pode a decisão de mérito ir além, ficar aquém ou dar coisa diversa do que foi pedido pelo autor. 
interesses metaindividuais" ${ }^{337}$. Ainda mais enfático, GIDI propõe romper com a teoria de que o objeto do processo é rigidamente delimitado pelo pedido feito pelo autor na petição inicial, pois, nessa fase, "a controvérsia e suas conseqüências ainda estão imaturas",338.

Conseqüentemente, o objeto do processo coletivo deverá abranger toda a controvérsia coletiva, independentemente do pedido. Esse abrandamento do princípio da adstrição/congruência viria (i) condicionado ao devido processo legal; e (ii) embasado na lei norte-americana, que já foi rígida e formalista e, hoje, não exige que o pedido seja feito expressamente na petição inicial - tendência essa que vem sendo internacionalmente seguida $^{339}$. Com o objeto coletivo assim delimitado GIDI conclui que "não haverá casos de continência ou conexão - somente litispendência - simplificando sobremaneira o processo coletivo" ${ }^{340}$. É o que veremos mais adiante.

Desde logo, importa destacar a proposta contida no ANTEPROJETo DE Código Brasileiro de Processos Coletivos da USP, a esse respeito: “Art. $4^{\circ}$. Pedido e causa de pedir - Nas ações coletivas, a causa de pedir e o pedido serão interpretados extensivamente, em conformidade com o bem jurídico a ser protegido" (g.n.). Por igual, o MinistÉRIO DA JUSTIÇA/SECRETARIA DE REFORMA DO JUDiCIÁRIO propõe, em seu art. 18, parágrafo único, que "Ressalvada a ação de improbidade administrativa e a ação popular de proteção ao erário, a causa de pedir e o pedido serão interpretados extensivamente, em conformidade com o bem jurídico a ser protegido" (g.n.).

A esta altura, vale abrir um parêntese para abordar uma questão levantada por LEONEL, que, ao analisar as diferentes espécies de interesses coletivos lato sensu, destaca que os difusos são os interesses de grupos menos determinados de pessoas, sendo o mais autêntico dos interesses metaindividuais. A partir dessa constatação, e trazendo isso para o processo, o autor propõe que, quanto maior a indeterminação da coletividade interessada,

\footnotetext{
${ }^{337}$ MANCUSO, Rodolfo de Camargo. Uma análise comparativa entre os objetos e as legitimidades ativas das ações vocacionadas à tutela dos interesses metaindividuais: mandado de segurança coletivo, ação civil pública, ações do Código de Defesa do Consumidor e ação popular. Justitia, 54 (160), São Paulo: out./dez. 1992, p. 183.

${ }^{338}$ GIDI, Antonio. Rumo ..., op. cit., p. 46.

${ }^{339}$ Idem, ibidem, p. 46.

${ }^{340}$ Idem, ibidem, p. 49 (g.n.).
} 
menor a necessidade de especificação dos fatos, ou seja, menor a necessidade de substanciação da demanda ${ }^{341}$.

É da própria essência do interesse difuso uma abstração maior. Daí se dizer que, nessa hipótese, a conduta descrita tem "ontologicamente amplo espectro de incidência, o que impossibilita, ao menos em linha de princípio, que a inicial da ação traga minúcias não só do comportamento impugnado (...), como ainda do resultado (lesão)"342. Por conta disso, diz-se que a substanciação, nas demandas coletivas, torna-se mais tênue, bastando para isso que a descrição dos fatos seja suficientemente apta para demonstrar a situação material mais ampla, decorrente da própria essência dos interesses metaindividuais ${ }^{343}$.

Se assim é, se basta a descrição da conduta genericamente e se a descrição fática pode limitar-se à demonstração da situação material mais ampla, cabe reconhecer que não precisa haver uma identidade absoluta/literal entre as petições iniciais para fins de litispendência. Ambas serão descritas de maneira mais genérica, devendo o operador do direito atentar para sua essência, para os acontecimentos da vida, para o bem jurídico tutelado e, se preciso for, interpretar extensivamente a causa de pedir e o pedido.

Essa é mais uma das razões para não se ficar "preso" à literalidade da petição inicial, abrindo-se para a idéia de que a lide sociológica deve prevalecer sobre a lide processualizada - especialmente em sede de tutela de direitos coletivos. Com efeito, nos últimos tempos, os processualistas vêm se dando conta de que a máxima segundo a qual "o que importa para fins da tutela jurisdicional é o que o autor da demanda coletiva traz para o processo" não se sustenta ${ }^{344}$, tendo em vista que a sentença condenatória não resolve o conflito de interesses existente no plano real. Assumindo isso como verdade e trazendo este conceito para o tema objeto do presente estudo, pode-se dizer que, para fins de identificação das demandas, o conflito que deve ser confrontado é a lide sociológica, e não apenas a porção da lide trazida pelo autor da demanda.

\footnotetext{
${ }^{341}$ LEONEL, Ricardo de Barros. A causa petendi..., op. cit., p. 148.

${ }^{342}$ Idem, ibidem, p. 148/149.

${ }^{343}$ Idem. Manual..., op. cit., p. 232 (g.n.).

${ }^{344}$ Nesse sentido, Rodolfo de Camargo MANCUSO destaca-se como um dos autores que mais tem defendido o incremento dos meios alternativos de solução de conflitos.
} 


\section{III.5.3. Causa de pedir próxima e pedido imediato: elementos 'secundários'}

Este subitem demonstra que a causa de pedir próxima e o pedido imediato, conquanto importantes, não são primordiais para fins de identificação das demandas. Em outras palavras, havendo coincidência entre a causa de pedir remota e o pedido mediato, aqueles outros dois elementos objetivos não são suficientes para impedir o reconhecimento da litispendência.

Com relação à causa de pedir próxima, no mais das vezes, ela contém não só os fundamentos jurídicos do pedido, como, também, informações de cunho social, político e ideológico, isto é, fatos secundários voltados quase que exclusivamente ao convencimento do juiz. Nesse sentido, LEONEL reconhece que os fatos secundários trazidos pela causa de pedir próxima, embora possam ser preponderantes para o acolhimento ou a rejeição da demanda, não se prestam, propriamente, à individuação da demanda, tratando-se de um mecanismo suasório $^{345}$. Se assim o é, pode-se concluir que a causa de pedir próxima tem menor relevância como elemento de identificação da demanda, não podendo ser empecilho para o reconhecimento da litispendência quando a causa de pedir remota e o pedido mediato forem, essencialmente, os mesmos.

Mesmo raciocínio aplica-se ao pedido imediato, isto é, ao tipo de provimento requerido. Em sede de demandas coletivas, considerando que o artigo 83 do CDC admite todas as espécies de ação para a tutela dos interesses coletivos, é possível que haja demandas com pedidos imediatos distintos, mas todas visando ao mesmo fim, ou seja, objetivando o mesmo resultado prático. Nesse caso, ontologicamente, o elemento petitum será o mesmo, de forma que a literalidade do pedido imediato não poderá ser empecilho ao reconhecimento da litispendência.

${ }^{345}$ LEONEL, Ricardo de Barros. A causa petendi..., op. cit., p. 154. Todavia, no Manual do Processo Coletivo (op. cit.), o autor refere-se a essa mesma questão em sentido oposto: "a fundamentação valorativa (...) não configura dados simplesmente secundários do conflito (...), mas dados essenciais, servindo à individualização da demanda coletiva" (p. 234). 
Este é o caso, por exemplo, de duas ações civis públicas ambientais propostas por diferentes legitimados ativos contra a mesma empresa poluidora: em uma delas, o pedido é de cassação da licença ambiental (constitutiva negativa) e, na outra, de paralisação das atividades (condenatória em obrigação de não fazer), mas ambas objetivam, em uma interpretação extensiva, a mesma coisa: o estancamento daquela atividade poluidora.

A expressão "estancamento daquela atividade poluidora" traz, em si, os dois elementos necessários e suficientes para identificar as ações: (i) o fato constitutivo do direito alegado - a poluição -, que constitui a causa de pedir remota ('fato violador'); e (ii) a finalidade das demandas - o estancamento da atividade, com vistas a melhorar a qualidade do ambiente -, que constitui o pedido mediato (o bem da vida).

Corroborando esse entendimento, o Tribunal Regional Federal da $4^{\mathrm{a}}$ Região já decidiu pela reunião de duas ações civis públicas ambientais dada a semelhança do pedido mediato (preservação do ecossistema do rio Jacuí), salientando que o bem jurídico coletivo (o rio) deve ser o objeto central da tutela coletiva, ainda que os pedidos imediatos sejam distintos, desde que conduzam a um mesmo resultado: a efetiva proteção do bem da vida $^{346}$. Assim, a bem ver, também a identidade dos pedidos imediatos pode ser mitigada, contanto que esteja bem delineada a identidade de propósitos, o fim último que se visa a atingir com ambas as ações, o resultado prático dos processos, enfim, o bem jurídico por elas tutelado.

É preciso mencionar, no particular, a relação estabelecida entre a espécie de interesse coletivo tutelado (difuso x coletivo em sentido estrito $\mathrm{x}$ individuais homogêneos) e o pedido imediato. Em linhas gerais, a doutrina entende que o pedido imediato divergirá conforme se trate de interesses difusos, coletivos em sentido estrito ou individuais homogêneos, o que afastaria a identidade de ações pelo tipo de provimento jurisdicional requerido.

346 TRF da $4^{\text {a }}$ Região. Turmas Reunidas. Conflito de Competência - CC 8904007089, Rel. Juiz Oswaldo Alvarez, j, 20.05.1992, v.u., DJU 15.07.1992. 
Como salienta GIDI, “o pedido da ação coletiva de direito difuso é absolutamente diverso do pedido de condenação genérica de responsabilidade civil por danos individuais" 347 .

No mesmo sentido, MANCUSO entende que:

Se a concomitância ocorre entre duas ações que, posto relevem de uma mesma causa remota (v.g., publicidade enganosa) visam cada qual a tutela de diferentes dimensões do interesse metaindividual (numa, o interesse difuso à correta divulgação dos produtos e serviços e supressão da mensagem publicitária viciada; noutra, o interesse individual homogêneo ao ressarcimento devido à comunidade dos lesados individuais), é claro que aí não se configura a litispendência, podendo, eventualmente, dar-se a continência ou a conexão, conforme se apresente o caso concreto $^{348}$.

Em que pese isso, concessa maxima venia, é possível argumentar que a espécie de interesse diz respeito não ao tipo de provimento jurisdicional, mas ao próprio bem jurídico tutelado, que poderá ter natureza difusa, coletiva ou individual homogênea. A esse respeito, vale lembrar a distinção trazida por SANTOS, segundo a qual "o pedido imediato consiste na providência jurisdicional solicitada: sentença condenatória, declaratória, constitutiva ou mesmo providência executiva, cautelar ou preventiva" ${ }^{\text {349, }}$, ao passo que o pedido mediato é a utilidade que se quer alcançar pela sentença. Nas ações coletivas, como se sabe, o pedido imediato tem, em regra, natureza condenatória, eis que consubstanciado em obrigações de fazer, não fazer e dar (artigo $3^{\circ}$ da LACP). Disso extrai-se que a diferenciação quanto ao bem jurídico tutelado - se difuso, coletivo ou individual homogêneo - é questão afeta mais ao pedido mediato do que ao imediato.

\footnotetext{
${ }^{347}$ GIDI, Antonio. Coisa julgada..., op. cit., p. 221. No mesmo sentido, RODRIGUES, Marcelo Abelha. Ação Civil Pública..., op. cit., p. 145.

${ }^{348}$ MANCUSO, Rodolfo de Camargo. A concomitância de ações coletivas, entre si, e em face das ações individuais. In Revista dos Tribunais, ano 89, v. 782, São Paulo, dez. 2000, p. 40.

${ }^{349}$ AMARAL SANTOS, Moacyr. Primeiras linhas de direito processual civil. São Paulo: Saraiva, 1997, v.1, p. 163.
} 
De outro enfoque, BEDAQUE ressalta que qualificar um direito como difuso, coletivo ou individual homogêneo precede a própria judicialização do conflito, razão pela qual se opõe à afirmação de que "a tutela jurisdicional pleiteada [é] o elemento a determinar a natureza do interesse deduzido em juízo. Ao contrário, é o tipo de direito que determina a espécie de tutela",350.

Por seu turno, VENTURI afirma haver relação de litispendência ou continência entre uma ação coletiva em defesa de direito difuso e outra em defesa de direitos individuais homogêneos. Isso porque as ações em defesa de direito difuso contêm, implicitamente, um pedido de condenação genérica que já abrangeria a tutela dos direitos individuais homogêneos ${ }^{351}$. Conclui que:

Já estando inserida a pretensão de tutela de direitos individuais homogêneos na demanda difusa ou coletiva, haverá, necessariamente, relação de litispendência, continência ou de coisa julgada assim que ajuizada a demanda de tutela de direitos individuais homogêneos, devendo, portanto, ou determinar-se, ao menos, a reunião dos feitos, ou rejeitar-se liminarmente a admissão desta última, respectivamente ${ }^{352}$.

O mesmo se diga em relação ao "nome" ou ao "tipo" de ação coletiva ou à Lei na qual se funda a ação: Lei da Ação Popular, Lei da Ação Civil Pública, Código de Defesa do Consumidor ou Lei do Mandado de Segurança ${ }^{353}$.

No entender de RODRIGUES, a mera diferença de procedimento não afasta a identidade entre tais ações, uma vez que o procedimento não constitui o elemento identificador da demanda ${ }^{354}$. A esse respeito, já ensinava CHIOVENDA que "pouco

\footnotetext{
${ }^{350}$ BEDAQUE, José Roberto dos Santos. Direito e processo: influência do direito material sobre o processo. São Paulo: Malheiros, 1997, p. 34/36.

${ }^{351}$ Como, por exemplo, o reconhecimento da responsabilidade civil do infrator - an debeatur -, permitindo, desde logo, a liquidação e execução individuais - quantum debeatur -, com base na sentença de procedência da ação em defesa de direito difuso.

${ }^{352}$ VENTURI, Elton. Processo Civil Coletivo. São Paulo: Malheiros, 2007, p. 338.

${ }^{353}$ Sobre o contraste entre ação civil pública e ação popular, vide CRUZ E TUCCI, José Rogério e TUCCI, Rogério Lauria. Devido processo legal e tutela jurisdicional. São Paulo: Revista dos Tribunais, 1993, p. 138 e ss.

${ }^{354}$ RODRIGUES, Marcelo Abelha. Ação Civil Pública..., op. cit., p. 139.
} 
importa que as duas causas procedam de demandas concebidas em forma diversa ou em formas de procedimentos diversos" ${ }^{\text {355 }}$. Com efeito,

\begin{abstract}
Não será pelo fato de se tratar de demandas nominalmente distintas (ação civil pública, ação popular, mandado de segurança coletivo, ação de improbidade administrativa etc.) que, teoricamente, poderá deixar de existir entre todas elas relação de litispendência, conexão ou continência, e, conseqüentemente, a rejeição das posteriores ou sua reunião perante o juízo prevento ${ }^{356}$.
\end{abstract}

Como salienta GIDI, se entre essas ações ocorrer identidade de causa de pedir e de pedido, haverá litispendência: "serão a mesma e única ação coletiva, apenas propostas com base em leis processuais diferentes" ${ }^{, 357}$. Em adição, GRINOVER ${ }^{358}$ e MAZZILLI ${ }^{359}$ entendem que, nessa hipótese, as ações não poderão coexistir, sob pena de resultarem em decisões contraditórias. Isso porque "entre a ação civil pública e a ação popular existe, quanto ao objeto, um vasto núcleo comum, justificado pela aptidão de ambas para a tutela judicial de interesses difusos" 360 , o que, em última análise, permite que se reconheça a "identidade" entre elas.

Em sentido contrário, em estudo de 1991, BARBOSA MOREIRA aponta uma possível diferença entre as Ações Civil Pública e Popular: por se tratar de 'ação de responsabilidade por dano', a Ação Civil Pública, se julgada procedente, desembocará em uma sentença condenatória (obrigação de fazer, não fazer ou dar), ao passo que a Ação Popular, por cuidar de 'atos eivados de vício de ilegalidade', desembocará, se procedente, em uma sentença declaratória ou constitutiva, embora, eventualmente, com alguma condenação assessória $^{361}$. Segundo o autor, essa diferença seria suficiente para afastar eventual bis in idem. Ocorre, porém, que, de 1991 para cá, a doutrina evoluiu e passou a

\footnotetext{
${ }^{355}$ CHIOVENDA, Giuseppe. Instituições..., op. cit., v.II, p. 387.

${ }^{356}$ VENTURI, Elton. Processo..., op. cit., p. 340.

357 GIDI, Antonio. Coisa julgada..., op. cit., p. 219. No mesmo sentido, LEONEL, Ricardo de Barros. Manual..., op. cit., p. 229. Ainda, sobre o assunto, destacam-se os seguintes julgados: STJ - Resp 208680/MG - $2^{\text {a }}$ Turma - Min. Peçanha Martins - j. 31.05.2004; STJ - RMS 12550/RJ - 2 ${ }^{\mathrm{a}}$ Turma - Min. Eliana Calmon - j, 12.08.2002; e STJ - Resp 158536/SP - 1a Turma - Min. Garcia Vieira - j. 17.04.1998.

${ }^{358}$ GRINOVER, Ada Pellegrini. Uma nova modalidade de legitimação à ação popular. Possibilidade de conexão, continência e litispendência. In Ação Civil Pública - reminiscências e reflexões após 10 anos de aplicação. MILARÉ, Édis (Coord.). São Paulo: Revista dos Tribunais, 1995, p. 23/27.

${ }^{359}$ MAZZILLI, Hugo Nigro. A defesa dos interesses difusos..., op. cit., p. 229.

${ }^{360}$ MANCUSO, Rodolfo de Camargo. Ação Civil Pública..., op. cit., p. 215.

${ }^{361}$ BARBOSA MOREIRA, José Carlos. Ações coletivas na Constituição..., op. cit..
} 
reconhecer que o objeto da ação civil pública é muito mais amplo e pode ter natureza, inclusive, mandamental. Com isso, é plenamente possível que os objetos de uma e de outra ação coincidam, não sendo, dadas todas as vênias ao grande doutrinador, empecilho para o reconhecimento de litispendência, por exemplo.

\section{III.6. Conclusão preliminar: identidade de seis elementos $x$ semelhança de dois elementos}

Embora a teoria dos tria eadem seja toda baseada na identidade dos três elementos, é certo que cada um desses elementos se subdivide em dois (pólo ativo e passivo; causa de pedir próxima e remota; pedido mediato e imediato), de forma que a tríplice identidade, pode-se dizer, é "sêxtupla". Dessa forma, pela regra do CPC, para que duas ações possam ser consideradas idênticas ou repetidas, é necessário que haja coincidência dos seis elementos, o que é bastante difícil de acontecer na prática.

É possível, no entanto, imaginarmos uma situação em que os seis elementos não sejam absolutamente idênticos e, mesmo assim, as ações sejam repetidas (litispendentes). Naturalmente, para tanto, será necessário adotar uma visão mais flexível das regras do CPC (e mais consentânea com a realidade da jurisdição coletiva). Com efeito, ainda que os elementos de duas ou mais ações não sejam absolutamente idênticos, pode acontecer de todas as demandas estarem inseridas no mesmo contexto social, temporal e geográfico, e, mais do que isso, visarem ao mesmo resultado prático, de forma que, em uma visão mais flexível, elas podem ser consideradas a mesma e única ação.

Daí se dizer que, em sede de jurisdição coletiva, é possível que duas ações sejam a mesma e única demanda ainda que, dos seis elementos, apenas dois sejam comuns. Os elementos necessários e suficientes para se reconhecer a identidade de ações coletivas são a causa de pedir remota e o pedido mediato. A conjugação desses dois elementos permite identificar o núcleo essencial da demanda, o thema decidendum, o bem jurídico coletivo tutelado em ambas as ações - o que, em última análise, não escapa da análise (subsidiária) da própria relação jurídica substancial. 
Mas a modernização dos conceitos tradicionais do processo civil não pára por aí. Além do foco na causa de pedir remota e no pedido mediato, é possível afirmar que tais elementos não precisam ser rigorosamente idênticos para que as ações sejam consideradas a mesma; basta que eles sejam semelhantes ou comuns $^{362}$. A expressão comum é, aqui, empregada no sentido de tudo aquilo que é "compartilhado" por mais de uma pessoa, no sentido de "algo em comum". Mais especificamente, estamos a nos referir à contextura existencial $^{363}$ e ao resultado prático visado pelas ações coletivas, que poderão ser comuns a todas.

De posse desses conceitos, vale analisar brevemente um caso concreto, ocorrido em 2003 no Estado de Santa Catarina. Trata-se da implantação de uma unidade industrial, cujo licenciamento foi presidido pelo o órgão ambiental estadual. Apresentados o Estudo de Impacto Ambiental o respectivo Relatório de Impacto Ambiental - EIA/RIMA e realizada audiência pública, o órgão competente analisou os impactos positivos e negativos do empreendimento e concluiu pela sua viabilidade ambiental, razão pela qual emitiu_a Licença Ambiental Prévia.

Contrapondo-se ao projeto, três associações civis ambientalistas propuseram uma primeira Ação Civil Pública, visando a obstaculizar a implantação da unidade industrial, bem como impedir o licenciamento ambiental do empreendimento, sob a alegação de riscos ao meio ambiente. Nesta primeira ação, foram requeridas a declaração de ilegalidade da Licença Ambiental Prévia, assim como a declaração de inviabilidade do projeto. Ainda, requereu-se a condenação da empresa à obrigação de não fazer, consistente em não promover a instalação do empreendimento e a condenação do órgão ambiental em absterse de expedir quaisquer licenças ou autorizações.

Indeferida a decisão liminar, o licenciamento teve seguimento, sendo emitida a Licença Ambiental de Instalação. Às vésperas da emissão da Licença Ambiental de Operação, outras tantas ações civis públicas foram propostas, por diferentes legitimados

\footnotetext{
${ }^{362}$ Como pontua ARAÚJO FILHO, Luiz Paulo da Silva: “a ação coletiva será a mesma quando forem comuns a causa de pedir e o pedido" (In Comentários ao Código de Defesa do Consumidor. São Paulo: Saraiva, 2002, p. 198 - g.n.).

${ }^{363}$ Cf. LUCON, Paulo Henrique dos Santos, GABBAY, Daniela Monteiro, ALVES, Rafael Francisco e ANDRADE, Tathyana Chaves de. Interpretação do pedido..., op. cit., p. 195/196.
} 
ativos, em comarcas distintas, ora na Justiça Estadual, ora na Justiça Federal, todas elas com o mesmo objetivo: impedir ou dificultar a implantação do empreendimento.

Na segunda Ação Civil Pública, a associação civil requereu a declaração de nulidade das Licenças Ambientais emitidas; a inviabilização do empreendimento; a demolição das obras já realizadas; e a reparação de eventuais danos causados.

Concomitantemente, houve a propositura de uma terceira Ação Civil Pública, por outra associação, na qual se requereu a paralisação dos testes que vinham sendo realizados na unidade industrial.

Não bastasse, uma quarta Ação Civil Pública foi proposta por outra associação, requerendo-se a declaração de nulidade das Licenças Ambientais emitidas, o deslocamento da competência para o licenciamento ambiental do órgão estadual para o federal e, por conseguinte, a reelaboração/reapresentação dos estudos ambientais.

Houve, ainda, uma quinta Ação Civil Pública, movida por outra associação, na qual foram requeridos: a interrupção das obras e testes referentes ao emissário de efluentes; a condenação da empresa à indenização pelos danos causados ao meio ambiente; nãoemissão da Licença Ambiental de Operação.

Por fim, uma sexta Ação Civil Pública foi proposta, desta vez pelo Ministério Público Federal, que requereu a condenação da empresa em obrigação de fazer, consistente na implantação dos controles ambientais necessários para que a empresa opere dentro dos padrões legais, sob pena de cessação de suas atividades.

Uma análise mais profunda (e flexível) das seis demandas permite concluir que todas elas têm um mesmo núcleo essencial e visam ao mesmo resultado prático: obstaculizar a implantação da unidade industrial, impedindo o seu licenciamento ambiental. É inegável que as demandas versam sobre o mesmo thema decidendum, sendo fácil notar que o bem jurídico tutelado por todas elas é um só. 
Assim, por mais que haja uma ou outra diferença ("cosmética") entre as petições iniciais, é certo que essas "nuances" nada mais são do que tentativas de "camuflar a identidade jurídica existente entre elas, justamente no intuito de tentar-se evitar a 'exceção' de litispendência oponível na segunda demanda"364. De fato, todas essas ações possuem a mesma causa de pedir remota e o mesmo pedido mediato: a causa de pedir é a suposta ilegalidade das licenças ambientais emitidas e o receio de dano ambiental decorrente das atividades da empresa, e o pedido mediato é a não-implantação do empreendimento.

Com base nisso, parece-nos possível sustentar a existência de verdadeira litispendência entre tais demandas, tanto por economia processual (não faz sentido a empresa ter que se defender em seis ações), quanto para evitar a prolação de decisões conflitantes. Afinal, se o juiz estadual determinar o prosseguimento do licenciamento, autorizando o funcionamento da unidade industrial e o juiz federal determinar sua imediata paralisação, declarando a inviabilidade ambiental do empreendimento, que decisão deverá ser implementada, considerando-se que o objeto é indivisível e a coisa julgada, erga omnes?

Daí porque o presente trabalho propõe - como resultado da flexibilização/modernização dos conceitos tradicionais do processo civil - não só um enfoque preponderante sobre a causa de pedir remota e o pedido mediato, como, também, um "abrandamento" da identidade absoluta, que poderá ser substituída pela semelhança desses dois elementos (interpretação extensiva). Embora essas alterações não estejam vigentes, nem na legislação processual individual, nem na coletiva, dada a inovação que encerram, é importante tê-las como paradigma.

${ }^{364}$ ARRUDA ALVIM. Ensaio..., op. cit., v. II, p. 102 (g.n.). 


\section{III.7. Ações coletivas $x$ ações individuais: exceção que confirma a regra}

A questão da relação entre demandas, no campo da jurisdição coletiva, ainda deve ser analisada em face da propositura de ações individuais. Todavia, por fugir do escopo do presente trabalho (concomitância/concorrência de demandas coletivas entre si), a relação entre demandas coletivas e individuais será analisada apenas en passant - embora o tema seja vasto e haja muita bibliografia a respeito.

Inicialmente, vale lembrar o que dispõe o artigo 104 do CDC:

Art. 104. As ações coletivas, previstas nos incisos I e II do parágrafo único do art. 81, não induzem litispendência para as ações individuais, mas os efeitos da coisa julgada erga omnes ou ultra partes a que aludem os incisos II e III do artigo anterior não beneficiarão os autores das ações individuais, se não for requerida sua suspensão no prazo de 30 (trinta) dias, a contar da ciência nos autos do ajuizamento da ação coletiva.

A doutrina é praticamente unânime em apontar a existência de erro de remissão no aludido dispositivo, tendo em vista a falta de correspondência entre os incisos I e II do parágrafo único do art. 81 e os incisos II e III do artigo 103 do CDC $^{365}$. Embora os doutrinadores concordem que há um erro de remissão no artigo 104, nem todos comungam do mesmo entendimento quanto àquela que seria a redação correta do aludido dispositivo.

De um lado, há quem sustente que o legislador excluiu, correta e propositalmente, o inciso III do parágrafo único do artigo 81 do $\mathrm{CDC}$, que alude aos interesses individuais homogêneos, por entender que a propositura de uma ação coletiva para tutelar esses interesses induziria litispendência para ações individuais. Nesse sentido, cite-se WAMBIER, para quem

\footnotetext{
${ }^{365}$ As ações a que aludem os incisos I e II do parágrafo único do art. 81 do CDC são, respectivamente, as destinadas a tutelar interesses difusos e coletivos (estrito senso). Os incisos II e III do artigo 103 do CDC, por sua vez, tratam dos efeitos da coisa julgada nas ações que visam a tutelar interesses coletivos (estrito senso) e individuais homogêneos, respectivamente.
} 
A coisa julgada das ações coletivas, como regra geral, não prejudica as ações em que o titular do direito pretende obter proteção do Judiciário pela via da ação individual. Essa afirmação é inteiramente verdadeira quando se trata de ações 'substancialmente coletivas', ou 'essencialmente coletivas', e não quando o caso é de ação em que se visa a proteção de direitos individuais homogêneos, que, na verdade, são direitos tipicamente individuais, (...) que recebem tratamento coletivizado, no plano do processo $^{366}$.

A distinção se justificaria, pois, no caso dos interesses difusos e coletivos (essencialmente coletivos). O objeto da demanda é um bem indivisivelmente considerado, o que é suficiente para distinguir essas ações coletivas das ações individuais, ao passo que, nas ações que visam à tutela de interesses individuais homogêneos (acidentalmente coletivos), o objeto é divisível, podendo coincidir com o objeto das ações individuais, donde se mostra pertinente a distinção feita pelo artigo 104 do CDC.

Nessa linha de raciocínio, nem mesmo sob uma ótica mais flexível (tal qual proposto no presente trabalho) haveria coincidência entre o núcleo essencial das demandas coletiva e individual, uma vez que o bem jurídico tutelado em ambas não seria o mesmo: naquela, trata-se de um bem indivisivelmente considerado (a recuperação do meio ambiente, por exemplo); nesta, do ressarcimento dos prejuízos individualmente sofridos (v.g., indenização pela perda do rebanho). Ainda que a causa de pedir remota seja a mesma, os pedidos mediatos são distintos, o que afasta eventual litispendência. Mas se fosse assim tão "óbvio" que não há litispendência entre demandas individuais e coletivas (fundadas nos incisos I e II do parágrafo único do art. 81 do $\mathrm{CDC}$ ), por que teria o legislador se preocupado em dizer isso?

Diante dessa e de outras indagações, grande parte da doutrina entende que o erro de remissão do artigo 104 do CDC estaria justamente no fato de terem sido excluídos os interesses individuais homogêneos (inciso III do parágrafo único do artigo 81 do CDC), o que não se justifica, sendo aplicável também - e principalmente - a essas ações coletivas a ressalva de que não induzem litispendência para as ações individuais. GIDI, por exemplo,

\footnotetext{
${ }^{366}$ WAMBIER, Teresa Arruda Alvim. Litispendência em ações coletivas. In Tutela Coletiva: 20 anos da Ação Civil Pública e Fundo de Defesa de Direitos Difusos, 15 anos do Código de Defesa do Consumidor. LUCON, Paulo Henrique dos Santos (Coord.). São Paulo: Atlas, 2006, p. 266.
} 
sustenta que a regra do artigo 104 vale, indistintamente, para as três espécies de ações coletivas, por entender que, em qualquer das espécies, afigura-se manifesta a “descoincidência entre os seus elementos. Quanto às partes, a descoincidência é total (...). Quanto às causas de pedir, a diferenciação é ainda mais delicada (...). Também os objetos de ambos os processos (...) são diversos"367.

Especificamente com relação ao objeto das ações, GIDI entende que o pedido da ação coletiva para tutela de interesses individuais homogêneos é próprio (pedido de condenação genérica) e não se confunde com o mero somatório de pedidos individuais (como se um litisconsórcio ativo fosse). A diferença entre ambos está na dimensão com que é tomado: lá, o pedido assume uma dimensão coletiva, aqui, limita-se à sua dimensão individual. Isso explica porque as ações relacionadas ao Plano Bresser, por exemplo, não foram consideradas idênticas/litispendentes (ainda que idênticas as causas de pedir, os pedidos haviam sido tomados em diferentes dimensões).

Apesar de serem tecnicamente distintas, é inegável que "a causa de pedir da demanda individual está inserida no mesmo contexto social, temporal e geográfico da causa de pedir da demanda coletiva" ${ }^{\natural 68}$. Essa semelhança de contextos / causas de pedir aproxima-se muito do quanto proposto no presente trabalho, de tal forma que, em rigor, a flexibilização dos institutos processuais poderia levar ao reconhecimento da litispendência não só das ações coletivas, entre si, como, também, em face das ações individuais, o que entraria em choque com texto expresso de lei. Ocorre, porém, que o artigo 104 do CDC pode ser entendido como uma exceção que confirma a regra. O legislador pode ter feito uma opção consciente pela não-aplicação da regra geral - reconhecimento da litispendência -, em prol de outros valores, como o acesso à Justiça, o devido processo legal e a participação democrática.

Afastada, ex vi legis, a litispendência entre demandas coletivas e individuais, é preciso considerar, ainda, a existência de eventual conexão, por força de uma íntima relação existente entre elas, como ocorre, por exemplo, com uma demanda (coletiva) em defesa do meio ambiente e uma demanda (individual) por "dano ricochete", originadas de

\footnotetext{
${ }^{367}$ GIDI, Antonio. Coisa Julgada..., op. cit., p. 208.

368 LUCON, Paulo Henrique dos Santos, GABBAY, Daniela Monteiro, ALVES, Rafael Francisco e ANDRADE, Tathyana Chaves de. Interpretação..., op. cit., p. 195.
} 
um mesmo vazamento de efluentes industriais. A esse respeito, analisando a repercussão do julgamento de procedência de uma ação coletiva sobre as respectivas ações individuais, MANCUSO observa que:

O acolhimento do pedido coletivo trará embutido o reconhecimento de que a causa de pedir indicada na ação individual é fundada (...) e esse fundamento, provavelmente acarretará o acolhimento das demandas individuais, na medida em que estas vêm igualmente reportadas à tal causa de pedir; para GRINOVER, o fenômeno se explica pela 'ampliação ope legis do objeto do processo, para incluir na coisa julgada decisão sobre a causa petendi'. Aliás, isso ocorre pela boa razão de que uma coisa não pode, ao mesmo tempo, ser e não $\operatorname{ser}^{369}$.

A partir disso, conclui o autor, tomando como exemplo as ações de controle de constitucionalidade: "o motivo da declaração de constitucionalidade faz coisa julgada, impedindo novas argüições com base nos mesmos fundamentos" ${ }^{370}$.

Resta saber se, a despeito dessa semelhança, a melhor solução prática a ser adotada seria a reunião (obrigatória) das demandas para julgamento conjunto. Muitos autores sustentam que, em razão de identidade parcial entre as demandas individuais e coletiva, devem todas ser reunidas, por conexão, para julgamento conjunto. Nesse sentido, VENTURI e PIZZOL ${ }^{371}$, dentre tantos outros. GRINOVER, por sua vez, já sustentou que o objeto da ação coletiva para defesa de interesses individuais homogêneos seria abrangente e conteria o pedido nas correspondentes ações individuais, levando a concluir tratar-se de uma relação de continência ${ }^{372}$. Mesmo nessa hipótese, a conseqüência prática seria a mesma: reunião para julgamento simultâneo.

\footnotetext{
369 GRINOVER, Ada Pellegrini. Da coisa julgada no Código de Defesa do Consumidor. Revista da Associação dos Advogados de São Paulo, n. 33, dez. 1990, p. 8. Apud MANCUSO, Rodolfo de Camargo. A concomitância de ações coletivas, entre si..., op. cit., p. 33 (g.n.).

${ }^{370}$ MANCUSO, Rodolfo de Camargo. Jurisdição coletiva..., op. cit., p. 103 (g.n.).

${ }^{371}$ VENTURI, Elton. Processo..., op. cit., p. 360/363; PIZZOL, Patrícia Miranda. A competência no processo civil. São Paulo: Revista dos Tribunais, 2003, p. 584.

372 Revendo seu posicionamento anterior, a autora passou a entender que haveria não mais relação de continência, mas, sim, de prejudicialidade externa da ação coletiva em relação às ações individuais, impondo-se a suspensão destas.
} 
Tal solução favoreceria, por certo, a efetividade da tutela jurisdicional, na medida em que viabilizaria o processamento e o julgamento simultâneos, afastando o problema de uma eventual colidência lógica entre os julgados, evitando perplexidades e, mesmo, a suscitação de violação do princípio constitucional da isonomia ${ }^{373}$. Embora isso seja verdade, não se pode olvidar dos

Problemas pragmaticamente previsíveis que decorreriam da reunião de todas as coes individuais e coletivas conexas e/ou continentes perante um mesmo juízo, sobretudo em relação ao eventual comprometimento da celeridade da prestação jurisdicional - valor hoje alçado ao status de verdadeira garantia constitucional ${ }^{374}$.

Ao fator celeridade, some-se, ainda, o acesso à justiça, no sentido literal/físico da palavra. Não só porque o espírito do artigo 104 do CDC foi o de permitir que o indivíduo possa acessar diretamente o Judiciário, mas pelas distâncias continentais do nosso país: se um gaúcho tiver de propor sua ação individual em Natal/RN, provavelmente, deixará de fazê-lo.

Assim, por ser inviável, muitas vezes, reunir todas as ações no juízo prevento, a conseqüência prática da relação entre demandas individuais e coletivas pode não ser a adoção da sistemática da conexão.

Por fim, cumpre analisar a proposta do ANTEPROJETo DE Código BRASILEIRO DE PRocessos Coletivos DA USP a respeito do tema.

Art. $6^{\circ}$ Relação entre demanda coletiva e ações individuais - A demanda coletiva não induz litispendência para as ações individuais em que sejam postulados direitos ou interesses próprios e específicos de seus autores, mas os efeitos da coisa julgada coletiva (art. 12 deste Código) não beneficiarão os autores das ações individuais, se não for requerida sua suspensão no prazo de 30 (trinta) dias, a contar da ciência efetiva da demanda coletiva nos autos da ação individual.

\footnotetext{
${ }^{373}$ Quanto à isonomia, VENTURI, Elton ressalta que não há ofensa ao princípio, pois o indivíduo que escolheu ir a juízo diferencia-se dos demais, na medida em que, para ele, cai por terra a "presunção (relativa) de inacessibilidade pessoal à justiça" (In Processo..., op. cit., p. 368).

${ }^{374}$ Idem, ibidem, p. 361.
} 
$\S 1^{\circ}$ Cabe ao demandado informar o juízo da ação individual sobre a existência de demanda coletiva que verse sobre idêntico bem jurídico, sob pena de, não o fazendo, o autor individual beneficiar-se da coisa julgada coletiva mesmo no caso de a ação individual ser rejeitada.

$\S 2^{\circ}$ A suspensão do processo individual perdurará até o trânsito em julgado da sentença coletiva, facultado ao autor requerer a retomada do curso do processo individual, a qualquer tempo, independentemente da anuência do réu, hipótese em que não poderá mais beneficiar-se da sentença coletiva.

$\S 3^{\circ}$ O Tribunal, de ofício, por iniciativa do juiz competente ou a requerimento da parte, após instaurar, em qualquer hipótese, o contraditório, poderá determinar a suspensão de processos individuais em que se postule a tutela de interesses ou direitos referidos a relação jurídica substancial de caráter incindível, pela sua própria natureza ou por força de lei, a cujo respeito as questões devam ser decididas de modo uniforme e globalmente, quando houver sido ajuizada demanda coletiva versando sobre o mesmo bem jurídico.

$\S 4^{\circ} \mathrm{Na}$ hipótese do parágrafo anterior, a suspensão do processo perdurará até o trânsito em julgado da sentença coletiva, vedada ao autor a retomada do curso do processo individual antes desse momento (g.n.).

Inicialmente, nota-se que o ANTEPROJETO não traz qualquer distinção quanto à espécie de demanda coletiva, abrangendo tanto as ações que tenham por objeto a tutela de interesses difusos e coletivos, quanto as que visam à defesa de interesses individuais homogêneos.

A redação do caput do artigo $6^{\circ}$ eliminou a possibilidade de contradição prática (mas não lógica) de julgados, ao estabelecer que os indivíduos que não suspenderem suas ações individuais, não se beneficiarão da sentença coletiva - a menos que o demandado, a quem incumbe o dever de informar a concomitância de ações, não o faça $\left(\S 1^{\circ}\right)$.

$\mathrm{O} \S 2^{\circ}$ solucionou a questão relativa ao tempo de duração da suspensão do processo individual, estabelecendo regra específica para a jurisdição coletiva, não mais se aplicando a regra clássica (e inadequada) do artigo $265, \S 5^{\circ}$, do CPC. Neste ponto, o ANTEPROJETO 
DA USP assemelha-se, em muito, à PROPOSTA DO MINISTÉRIO DA JUSTIÇA/SECRETARIA DE REFORMA DO JUDICIÁRIO ${ }^{375}$.

O $\S 3^{\circ}$ trata do que WATANABE convencionou chamar de ações pseudoindividuais, que será visto a seguir. Diferentemente do que permite o $\S 2^{\circ}$, o $\S 4^{\circ}$ veda ao autor da ação pseudoindividual retomar sua ação, até o trânsito em julgado da sentença coletiva.

\section{III.7.1. Peculiaridade: ações pseudo-individuais}

Ainda dentro deste subitem, cabe analisar a questão das chamadas ações pseudoindividuais, que são aquelas propostas por indivíduos, com aparência de ações individuais, mas que, em verdade, têm alcance coletivo, dada a incindibilidade do seu objeto. Nesses casos, considerando a natureza jurídica da relação de direito material, o Judiciário deverá decidir a questão de modo uniforme e global para todos, sob pena de denegar-se acesso à justiça, por meio da prolação de decisões contraditórias, não só no plano teórico, mas no plano prático, para situações idênticas ${ }^{376}$.

375 “Art. 8\%. O ajuizamento de ações coletivas não induz litispendência para as correspondentes ações individuais, que tenham objeto correspondente, mas haverá a suspensão destas, até o julgamento da demanda coletiva em primeiro grau de jurisdição.

$\S 1^{\circ}$. Durante o período de suspensão, poderá o juiz perante o qual foi ajuizada a demanda individual conceder medidas de urgência.

$\S 2^{\circ}$. Cabe ao réu, na ação individual, informar o juízo sobre a existência de demanda coletiva que verse sobre idêntico bem jurídico, sob pena de, não o fazendo, o autor individual beneficiar-se da coisa julgada coletiva mesmo no caso de o pedido da ação individual ser improcedente.

$\S 3^{\circ}$. A ação individual somente poderá ter prosseguimento, a pedido do autor, se demonstrado mediante fundamentos idôneos a existência de graves prejuízos decorrentes da suspensão, caso em que não se beneficiará do resultado da demanda coletiva.

$\S 4^{\circ}$. A suspensão do processo individual perdurará até a prolação da sentença da ação coletiva, facultado ao autor, no caso de procedência desta e decorrido o prazo concedido ao réu para cumprimento da sentença, requerer a conversão da ação individual em liquidação provisória ou em cuprimento provisório da sentença coletiva, para apuração ou recebimento do valor ou pretensão a que faz jus.

$\S 5^{\circ}$. No prazo de 90 dias contados do trânsito em julgado da sentença coletiva, a ação individual suspensa será extinta, salvo se postulada a sua conversão em liquidação ou cumprimento de sentença coletiva.

$\S 6^{\circ}$. Transitada em julgado a sentença coletiva de improcedência do pedido que não seja fundada na insuficiência de prova, as ações individuais serão extintas.

$\S 7^{\circ}$. Em caso de julgamento de improcedência do pedido em ação coletiva por insuficiência de provas, a ação individual será extinta, salvo se não for requerido o prosseguimento no prazo de 90 dias contados do trânsito em julgado da sentença coletiva".

376 WATANABE, Kazuo. Relação entre demanda coletiva e demandas individuais. In Direito Processual Coletivo e o Anteprojeto de Código Brasileiro de Processos Coletivos. GRINOVER, Ada Pellegrini, 
Partindo da indivisibilidade do objeto, SALLES ensina que:

Uma medida em benefício de um interesse mais disperso pode reflexamente beneficiar um mais concentrado, e, reversamente, há situações nas quais, em razão da indivisibilidade do objeto, a defesa de um determinado bem, por um grupo ou mesmo por um indivíduo, pode atender, por via indireta, um interesse difuso ${ }^{377}$.

Assim, quando o objeto de uma demanda individual for indivisível, pode ocorrer de o seu atendimento, em prol do indivíduo, atingir, por via reflexa, a coletividade como um todo. Nessas hipóteses, a questão deverá ser decidida de modo uniforme e molecularmente. Mesmo se tratando de um bem indivisível, o cidadão está legitimado a agir, a exemplo do que já ocorria na Ação Popular romana, em que o indivíduo e a gens tinham o mesmo interesse e por isso ele é autorizado a agir.

Em termos práticos, basta pensar no caso de poluição ambiental: "sendo deferida uma obrigação de não fazer como a determinação do fechamento da fábrica, mesmo que em sede de demanda individual, estas medidas iriam beneficiar a todos os envolvidos" ${ }^{378}$, como decorrência lógica da indivisibilidade do objeto. Outros exemplos de demandas pseudo-individuais podem ser encontrados nos casos de poluição sonora, em que o fechamento de um estabelecimento a pedido de um vizinho traz reflexos para toda a coletividade, ou no caso de suspensão da fabricação de determinado medicamento a pedido de um consumidor.

Neste caso, pergunta-se: o artigo 104 do CDC teria aplicabilidade? A propositura de uma ação (pseudo)individual poderia configurar litispendência com uma ação coletiva? Tudo indica que sim. Se ambas as ações tiverem por base mesma relação jurídica substancial e objetivarem o mesmo resultado prático, qual seja, a tutela do

MENDES, Aluisio Gonçalves de Castro e WATANABE, Kazuo (Coords.). São Paulo: Revista dos Tribunais, 2007, p. 156.

${ }^{377}$ SALLES, Carlos Alberto de. Execução Judicial em Matéria Ambiental. São Paulo: Revista dos Tribunais, 1998, p. 141.

${ }^{378}$ GABBAY, Daniela. Processo coletivo e elementos objetivos da demanda. Dissertação (Mestrado). 23.10.2007. Orientador: Prof. Dr. Carlos Alberto de Salles. São Paulo, 2007. Faculdade de Direito, Universidade de São Paulo, p. 59. 
mesmo bem indivisível, a litispendência pode ser reconhecida, até para se evitar a prolação de decisões contraditórias.

Nesse sentido, vale lembrar que a questão foi muito bem tratada no art. $6^{\circ}, \S 3^{\circ}$, do Anteprojeto de Código Brasileiro de Processos Coletivos da USP (sem correspondência na PROPOSTA DO MinistÉRIO DA JUSTIÇA/SECRETARIA DE REFORMA DO JUDICIÁRIO). 


\section{CAPÍTULO IV - POSSÍVEIS SOLUÇÕES PARA O CONFLITO}

A partir de tudo o que se expôs - especialmente as flexibilizações propostas no Capítulo III - passa-se à análise das possíveis soluções práticas para a concomitância/concorrência de demandas coletivas, ponderando-se prós e contras de ambas as opões: reunião para julgamento conjunto (conexão) ou extinção das demandas subseqüentes (litispendência).

\section{IV.1. Qual a solução para o conflito?}

Reconhece-se, inicialmente, que a proposta de flexibilização apresentada no presente trabalho favoreceria a configuração da litispendência, dado o abrandamento dos seus requisitos ("identidade de seis elementos $x$ semelhança de dois elementos"). Nessa esteira, GRINOVER reconhece que o foco no bem jurídico a ser protegido e a interpretação extensiva da causa de pedir fazem com que a litispendência tenha um âmbito maior de aplicação ${ }^{379}$.

É certo, no entanto, que a conseqüência jurídica advinda do fenômeno ora estudado comporta, ainda, outro vetor. Vale dizer, diante de uma situação concreta de similaridade entre a causa de pedir remota e o pedido mediato de ações coletivas, existem, ao menos, duas formas de resolver o problema ${ }^{380}$ : (i) a reunião para julgamento conjunto (rectius $=$ conexão/continência); ou (ii) a extinção das ações subseqüentes (rectius = litispendência/coisa julgada).

\footnotetext{
${ }^{379}$ Cf. GRINOVER, Ada Pellegrini. Direito Processual Coletivo. In Tutela Coletiva - 20 anos da Lei da Ação Civil Pública e do Fundo de Defesa de Direitos Difusos e 15 anos do Código de Defesa do Consumidor. LUCON, Paulo Henrique dos Santos (Coord.). São Paulo: Atlas, 2006, p. 305/306 (g.n.).

${ }^{380}$ Cf. MANCUSO, Rodolfo de Camargo. A concomitância entre ações de natureza coletiva. In Direito Processual Coletivo e o Anteprojeto de Código Brasileiro de Processos Coletivos. GRINOVER, Ada Pellegrini, MENDES, Aluisio Gonçalves de Castro e WATANABE, Kazuo (Coords.). São Paulo: Revista dos Tribunais, 2007, p. 173. No mesmo sentido, GIDI, Antonio, para quem pode ocorrer a reunião dos processos idênticos em um único juízo, ou extinção de todos, exceto um, em geral, o primeiro (In Rumo..., op. cit., p. 310/311).
} 
Segundo bem observado por GIDI "uma vez que a litispendência coletiva seja determinada, resta decidir a melhor solução para o conflito. Trata-se de uma escolha

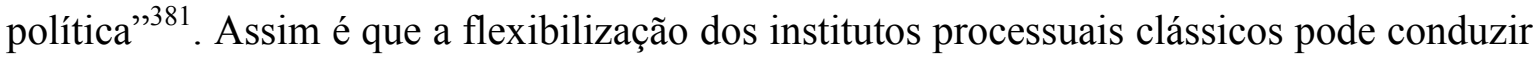
tanto à conexão/continência, quanto à litispendência/coisa julgada.

\title{
IV.1.1. Reunião para julgamento conjunto (conexão / continência)
}

Não há dúvida de que a doutrina e a jurisprudência majoritárias optam pela reunião para julgamento conjunto. Essa opção é vista, pela maioria dos doutrinadores, como a saída mais adequada para solucionar a relação entre demandas coletivas. Trata-se de solução que, a um só tempo, preserva a legitimação concorrente-disjuntiva para a defesa dos interesses coletivos (lato sensu) e evita a prolação de decisões contraditórias.

A reunião de processos coletivos poderia ser a melhor solução, por quatro motivos: (i) porque o segundo processo pode estar mais adiantado que o primeiro; (ii) porque o autor do segundo processo pode ser mais adequado do que o do primeiro; (iii) porque os processos podem ter objetos diferentes; e (iv) porque, com a reunião, todos os colegitimados poderão participar do processo $^{382}$.

Nessa linha, MANCUSO destaca que:

\begin{abstract}
A reunião das ações assemelhadas consulta ao ideal da democracia participativa, na medida em que não se tolhem as iniciativas de cada qual dos co-legitimados ativos, e ao mesmo tempo evitam-se os riscos do trâmite em paralelo dessas ações afins, as quais ficam reunidas para julgamento conjunto perante o Juízo que, tendo despachado a primeira delas, ficou prevento ${ }^{383}$.
\end{abstract}

\footnotetext{
${ }^{381}$ GIDI, Antonio. Rumo..., op. cit., p. 311.

${ }^{382}$ Cf. apontado por GIDI, Antonio. Ibidem, p. 311.

${ }^{383}$ MANCUSO, Rodolfo de Camargo. A concomitância entre ações de natureza coletiva. Op. cit., p. 167.
} 
Em adição, existem diversos precedentes jurisprudenciais do Superior Tribunal de Justiça determinando a reunião dos processos, a exemplo do Conflito de Competência $\mathrm{n}^{\mathrm{o}}$ 19686/DF, em que Ministro Demócrito Delgado proferiu o seguinte voto:

\begin{abstract}
O malefício de decisões contraditórias sobre a mesma relação de direito consubstancia a espinha dorsal da construção doutrinária inspirada no princípio da 'simultaneus processus' a que se reduz a criação do 'forum connexiatatis materialis'. O acatamento e respeito às decisões da justiça constituem o alicerce do Poder Judiciário que se desprestigiaria na medida em que dois ou mais juízes proferissem decisões conflitantes sobre a mesma relação jurídica ou sobre o mesmo objeto da prestação jurisdicional. A configuração do instituto da conexão não exige perfeita identificação das demandas, senão que entre elas preexista um liame que as torne passíveis de decisões unificadas ${ }^{384}$.
\end{abstract}

Encampando a tese de que os processos devam ser reunidos, GOMES JR. afirma que "havendo identidade de pedido(s) e causa(s) de pedir entre Ação Popular e Ação Civil Publica, devem os processos ser reunidos para decisão conjunta, não se justificando a extinção de um deles sob o argumento de que havia litispendência"385. Para o autor, deveria ser invocada a regra do art. $5^{\circ}, \S 3^{\circ}$, da Lei $4.717 / 65$, para se reunir os processos perante o juízo prevento e, "caso haja decisões diferentes (liminares), deve ser cumprida aquela de lavra do juízo prevento, já que esse é quem irá julgar todas as demandas" ${ }^{386}$.

Boa parte da doutrina e da jurisprudência assenta sua conclusão no artigo $5^{\circ}, \S 3^{\circ}$, da Lei da Ação Popular, reiterado pelo artigo $2^{\circ}$, parágrafo único, da LACP (introduzido pela Medida Provisória n. 2.180-35/2001). Ocorre, porém, que a regra de prevenção estipulada nesses dispositivos nada mais é, a nosso ver, do que um critério de fixação de competência, não implicando, necessariamente, que demandas idênticas tenham de tramitar como se fossem conexas (i.e., reunidas para julgamento conjunto). A regra determina, apenas, que as futuras ações, sejam elas idênticas ou conexas à ação já ajuizada, devam ser julgadas (ou

\footnotetext{
${ }^{384}$ STJ, Conflito de Competência CC 19686/DF, DJU 17.11.1997.

${ }^{385}$ GOMES JR, Luiz Manoel. Curso..., op. cit., p. 194 (g.n.).

${ }^{386}$ Idem, ibidem.
} 
extintas) pelo juízo prevento $^{387}$. Este, como se sabe, será aquele em que for distribuída a primeira ação coletiva, nos termos do artigo $2^{\circ}$, parágrafo único, da $\mathrm{LACP}^{388}$.

É preciso também considerar a importância do critério de prevenção na fixação do foro e do juízo competentes, nos termos dos arts. 106, 219 e 263 do CPC, assegurando prelação ao órgão jurisdicional a quem foi distribuída a primeira das ações confrontadas. Nesse sentido, MANCUSO destaca o posicionamento firmado pelo STJ, no sentido de que as ações civis públicas intentadas em juízos diferentes, com fundamentos idênticos ou assemelhados, devem ser reunidas perante o juízo a quem foi distribuída a primeira ação (prevento), a quem competirá processar e julgar todas as ações ${ }^{389}$.

Por seu turno, LUCON et al. defendem que, configurada a litispendência, pode ser "preferível que não ocorra a extinção do processo ulterior, mas a reunião das demandas ${ }^{, 390}$, pois isso certamente beneficiaria a tutela do bem jurídico coletivo. No mesmo sentido, GOMES JR. ${ }^{391}$, referindo-se à posição de PIZZOL, defende que, ainda que haja litispendência entre ações coletivas, não deve ser aplicada a regra (individualista) da extinção de um dos processos, conforme verbis:

$\mathrm{O}$ instituto processual da litispendência tem forte característica individualista, devendo ser aplicado com reservas quando estiver sendo objeto de análise ações coletivas. (...) Resumindo: ainda que haja coincidência entre o objeto de uma Ação Popular e uma Ação Civil pública, não há lugar para a invocação da litispendência, devendo haver a

\footnotetext{
${ }^{387}$ Nesse sentido, WAMBIER, Teresa Arruda Alvim. Litispendência em ações coletivas. In Processo Civil Coletivo. MAZZEI, Rodrigo e NOLASCO, Rita Dias (Coords.). São Paulo: Quartier Latin, 2005, p. 286/287 citando REZENDE FILHO, Gabriel, para quem "a prevenção pode ocorrer não só em relação a causas idênticas, como em relação a causa conexas" (In Curso de direito processual civil, v. 1, Saraiva, 1957, n. 147, p. 148).

${ }^{388}$ Por se tratar de regra especial, este critério de prevenção prevalece sobre os critérios do CPC. Sobre o tema, vide SCARPINELLA BUENO, Cassio. Conexão e continência entre ações de Improbidade Administrativa (Lei 8.429, de 1992, art. 17, $\S 5^{\circ}$ ). In Improbidade Administrativa - questões polêmicas e atuais. SCARPINELlA BUENO, Cassio e PORTO FILHO, Pedro Paulo de Rezende (Coords.). São Paulo: Malheiros, 2003; e, ainda, VENTURI, Elton. Processo..., op. cit., p. 342.

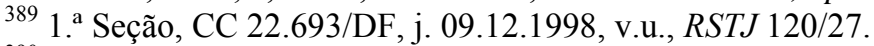

${ }^{390}$ LUCON, Paulo Henrique dos Santos, GABBAY, Daniela Monteiro, ALVES, Rafael Francisco e ANDRADE, Tathyana Chaves de. Interpretação do pedido..., op. cit., p. 195. Sustentam os autores que o Anteprojeto de Código Brasileiro de Processos Coletivos da USP teria adotado esta linha de raciocínio, ao modificar o tradicional efeito da litispendência para determinar a reunião dos processos ao invés da extinção das ações ulteriores.

${ }^{391}$ GOMES JR, Luiz Manoel. Curso..., op. cit., p. 193.
} 
reunião dos processos, com fundamento na conexão, para tramitação e decisão conjunta, raciocínio que se estende às demais Ações Coletivas ${ }^{392}$.

Para LUCON et al. a extinção das demandas ulteriores só seria admitida excepcionalmente, como no caso de mais de uma ação proposta pelo mesmo legitimado ativo $^{393}$. Com o devido respeito, ousamos discordar: o argumento está em contradição com outra afirmação dos mesmos autores, contida no mesmo estudo, no sentido de que "a identidade de partes, importante requisito, será flexibilizada para atentar à coletividade como um todo e não aos legitimados ativos que vieram em juízo"394. Se o que deve coincidir é a coletividade titular do bem (substituída), e não os substitutos processuais, por que diferenciar ações propostas pelo mesmo legitimado de ações propostas por legitimados distintos, reconhecendo a litispendência naquele caso e afastando neste? Concedida a devida vênia, parece não haver uma resposta satisfatória para tal diferenciação.

Por fim, e não com menos respeito, entendemos que também merece ressalva o entendimento de GOMES JR., no sentido de que "se já houve sentença, não há utilidade na reunião, devendo, aí sim, ser extinta a demanda ajuizada em segundo lugar, até pela ausência de interesse processual ${ }^{\text {"395 }}$. Com o devido respeito, a exceção acaba por infirmar a própria "regra" da conexão; afinal, se os institutos da litispendência e da coisa julgada são 'paralelos', não há justificativa plausível para se reconhecer a falta de interesse processual quando uma das demandas já foi julgada e negar esta mesma conclusão quando uma das demandas ainda estiver pendente.

\footnotetext{
${ }^{392}$ GOMES JR, Luiz Manoel. Curso..., op. cit., p. 196.

${ }^{393}$ No mesmo sentido (a contrario sensu), cite-se julgado do STJ, no qual foi a repetição de ações foi encarada como conexão e não como litispendência, por se tratar de diferentes legitimados ativos (STJ, $2^{\mathrm{a}}$ Turma, REsp 512074/RS, rel. Min. Franciuli Netto, j. 16.11.2004, apud WAMBIER, Teresa Arruda Alvim. Litispendência em ações coletivas. In Processo Civil Coletivo. MAZZEI, Rodrigo e NOLASCO, Rita Dias (Coords.). São Paulo: Quartier Latin, 2005, p. 289/290).

${ }^{394}$ LUCON, Paulo Henrique dos Santos et al. Op. cit., p. 195.

${ }^{395}$ GOMES JR, Luiz Manoel. Ibidem, p. 199.
} 


\section{IV.1.2. Extinção das demandas subseqüentes (litispendência / coisa julgada)}

Sem embargo dos argumentos acima expendidos, sempre de grande valia, não se pode negar a possibilidade de ocorrência de verdadeira litispendência, sempre que dois ou mais legitimados ativos intentarem ações coletivas com base nos mesmos eventos ocorridos no mundo dos fatos e visando ao mesmo resultado prático.

De início, importa reconhecer que existe um interesse público à higidez técnicojurídica da relação processual e à mantença da autoridade das decisões judiciais, o que nem sempre é solucionado pela conexão.

Isso porque nem sempre a reunião será possível ou nem sempre ela será determinada pelos juízes. Com efeito, embora NERY \& NERY entendam ser a reunião de processos obrigatória ${ }^{396}$, outros tantos doutrinadores defendem exatamente o contrário, que a reunião dos processos é uma faculdade do juiz. Nesse sentido, MAZZILLI sustenta que a reunião de processos é uma questão de conveniência e oportunidade:

\footnotetext{
No caso da conexão, a nosso ver, a reunião de processos é uma faculdade judicial e não uma norma cogente. (...) Deve mesmo existir uma certa margem de discricionariedade para o juiz ao avaliar até que ponto convém ou não a reunião das ações, para o que deverá levar em conta: a) a fase processual de cada uma delas no momento em que se identifica o nexo; b) qual o grau ou a intensidade da conexão entre elas, e em que nível seu julgamento em separado poderá provocar decisões inconciliáveis ${ }^{397}$.
}

\footnotetext{
${ }^{396}$ No mesmo sentido, RODRIGUES, Marcelo Abelha (Ação Civil Pública..., op. cit., p. 141); VENTURI, Elton (Processo..., op. cit., p. 339); GOMES JR., José Manoel (Curso..., op. cit., p. 188), dentre outros.

${ }^{397}$ MAZZILLI, Hugo Nigro. A defesa dos interesses difusos..., op. cit., p. 231.
} 
Em reforço, LEONEL assevera que esse juízo de conveniência deverá ser feito em cada caso concreto, tendo o juiz o poder de recusar a reunião dos processos - a exemplo do litisconsórcio multitudinário - toda vez que, ao invés de promover a economia e a instrumentalidade do processo, ela mostrar-se prejudicial (surgimento de incidentes procrastinatórios, multiplicidade de autores ou réus etc.).

De mais a mais, é sabido que, na hipótese de uma das demandas já ter sido sentenciada, a conexão não operará seus efeitos, por força da Súmula 235 do STJ ${ }^{398}$. A esse respeito, inclusive, já dizia CHIOVENDA que "subentende-se, pois, que, exatamente pela inderrogabilidade da competência por graus, não se pode, por mais íntima que seja a conexão, propor pela primeira vez a ação conexa em grau de recurso" ${ }^{\text {,99 }}$. Em casos tais, quando tiver sido proferida sentença em uma das ações, ARRUDA ALVIM entende que, a despeito da existência de conexão entre elas (como ocorre, por exemplo, com ações fundadas uma em erro e outra em dolo), deverá ser aplicada a "terapêutica da litispendência”, pois existe um risco real de decisões contraditórias ${ }^{400}$.

Se assim é, não se pode fechar os olhos para a hipótese de as ações não serem reunidas. Diante de ações objetivando o mesmo resultado prático, a partir dos mesmos eventos ocorridos no mundo dos fatos, a opção mais segura pode ser a extinção da segunda ação. Com isso, asseguram-se a indisponibilidade do bem coletivo, a economia processual e a harmonização de julgados. A esse respeito, GIDI é categórico: "Havendo litispendência, somente o primeiro processo será mantido, sendo os demais extintos (...). Parece ser essa a solução mais simples, prática e eficiente"401. No mesmo sentido, WAMBIER argumenta que não se pode correr o risco de haver decisões inconciliáveis; assim, considerando-se que a reunião das causas não ocorre necessária e inexoravelmente, a segunda ação coletiva deve ser extinta ${ }^{402}$.

Mais um argumento a favor da litispendência é lançado pela autora, desta vez, com base na inoperância do artigo 16 da LACP (especialmente para as ações de tutela de direitos difusos, em que o objeto é incindível):

\footnotetext{
398 "Súmula 235. A conexão não determina a reunião dos processos, se um deles já foi julgado".

${ }^{399}$ CHIOVENDA, Giuseppe. Instituições..., op. cit., v.II, p. 307/308.

${ }^{400}$ ARRUDA ALVIM. Ensaio..., op. cit., v. II, p. 100.

${ }^{401}$ GIDI, Antonio. Rumo..., op. cit., p. 49 (g.n.).

402 WAMBIER, Teresa Arruda Alvim. Litispendência em ações coletivas. In Processo Civil Coletivo. MAZZEI, Rodrigo e NOLASCO, Rita Dias (Coords.). São Paulo: Quartier Latin, 2005, p. 294.
} 
Claro está que se se entende que a coisa julgada, no que diz respeito aos direitos difusos se operaria realmente 'erga omnes', sendo o dano de âmbito nacional, uma só ação poderia ser proposta, havendo, em relação às subseqüentes, a mais pura litispendência - não sendo o caso, em absoluto, de se falar em conexão e de provocar a reunião das ações! $!^{403}$.

Nesse mesmo sentido, VENTURI entende que, além da necessidade de se assentar a ocorrência da litispendência mesmo quando diversos os seus proponentes, "resta ainda a tarefa de rechaçar a limitação territorial da eficácia dos provimentos das demandas coletivas" $^{\text {"404 }}$. Isso porque, segundo o autor, tal restrição tem acarretado a não-reunião de feitos por conexão ou continência e, conseqüentemente, a multiplicação de ações coletivas e decisões contraditórias, cada uma sendo eficaz sobre um território distinto, mesmo que a pretensão de tutela diga respeito a direitos essencialmente indivisíveis, como são os difusos e os coletivos.

Ainda, discordando do tratamento que é dado pela maioria da doutrina e jurisprudência às ações litispendentes (reunião para julgamento conjunto, como se conexas fossem), WAMBIER lança uma série de questionamentos:

O que ocorreria se uma ação popular estivesse em fase de RE e/ou REsp, e fosse intentada outra, por outro cidadão, com vistas a anular o mesmo ato, sob os mesmos fundamentos? Seria o caso de reuni-las? Teria a primeira ação seu curso suspenso? E, com isso, ficaria toda a comunidade prejudicada com a demora na resolução de um conflito que a envolve? Aplicar-se-ia à hipótese, realmente, a regra da conexão, segundo a qual as ações devem, mas não necessariamente, ser reunidas? Qual o modo então de se evitar decisões conflitantes prática e juridicamente? ${ }^{405}$.

Reservando a litispendência para casos extremos, MANCUSO pondera que a reunião por conexão ou continência tem em seu favor o fato de que "amiúde as ações coletivas sobre um mesmo tema não são exatamente iguais, porém assemelhadas, nelas

\footnotetext{
${ }^{403}$ WAMBIER, Teresa Arruda Alvim. Litispendência..., op. cit., p. 286 (grifos no original). ${ }^{404}$ VENTURI, Elton. Processo..., op. cit., p. 335.

${ }^{405}$ WAMBIER, Teresa Arruda Alvim. Ibidem, p. 288. No mesmo sentido, LACERDA, Galeno. Ação Civil Pública. Revista do MP do Rio Grande do Sul, n. 19, 1986 (conferência proferida em 17.10.1985).
} 
coincidindo o objeto ou a causa, ou então o pedido de uma, por sua extensão, já abrange o da outra"406.

Mas justamente por não ser muito comum que os pedidos imediato e mediato e as causas remota e próxima sejam precisamente iguais é que, acreditamos, não se pode ficar "preso" aos critérios rigorosos do CPC. Até porque, como visto, normalmente o que ocorre é que as demandas apresentam-se tentando "camuflar a identidade jurídica existente entre elas, justamente no intuito de tentar-se evitar a 'exceção' de litispendência oponível na segunda demanda"407.

No caso das ações coletivas propostas por ocasião da venda da empresa estatal Telebrás, MANCUSO entende que (i) foi melhor ter reunido, para evitar decisões conflitantes, mas reconhece que (ii) em rigor,

\begin{abstract}
Não sobeja espaço processual para uma segunda ação coletiva e bem assim para as subseqüentes, porque a primeira já é suficiente para cuidar do thema decidendum e já torna litigioso o objeto, além do que a tutela ofertada na jurisdição coletiva é de cunho molecular, cujo perímetro abrange as possíveis demandas-átomo, tudo em ordem a evitar a pulverização do conflito coletivo. Por esse viés, faltaria interesse de agir às ações coletivas ulteriores com o mesmo objeto da primeira, justificando-se a extinção delas sem julgamento de mérito (CPC, art. 267, VI) ${ }^{408}$.
\end{abstract}

De fato, se determinado bem jurídico coletivo já está sendo tutelado por um substituto da coletividade e se essa decisão terá efeitos erga omnes, não se vislumbra a presença dos requisitos necessidade e utilidade que justifique a propositura de nova demanda voltada à proteção do mesmo bem jurídico. Essa opção, segundo MANCUSO, parece ser "mais palatável aos operadores do direito do que a fórmula mais rigorosa da litispendência, que, sobretudo para os menos versados nas peculiaridades do processo coletivo, demandaria a coincidência integral dos tria eadem" ${ }^{409}$. Daí se dizer que, no caso

\footnotetext{
${ }^{406}$ MANCUSO, Rodolfo de Camargo. A concomitância entre ações de natureza coletiva. Op. cit., p. 167. ${ }^{407}$ ARRUDA ALVIM. Ensaio..., op. cit., v. II, p. 102 (g.n.).

${ }^{408}$ MANCUSO, Rodolfo de Camargo. Ibidem, p. 172.

${ }^{409}$ Idem, ibidem.
} 
de intercorrência de ações versando sobre um mesmo thema decidendum coletivo, em rigor, antes da própria litispendência (pressuposto processual negativo) haveria de reconhecer-se a falta de interesse processual (condição da ação) ${ }^{410}$.

Em um outro exemplo, ao analisar a transposição do rio São Francisco, MANCUSO aborda a concomitância de ações coletivas com objetivo comum e os problemas práticos que podem advir dessa situação: um juiz autorizando a transposição, outro, negando-a ${ }^{411}$. Inicialmente, o autor salienta que o objeto litigioso destas demandas (o manejo das águas do rio São Francisco) têm natureza unitária - trata-se do típico objeto indivisível a que alude o artigo 81, I, CDC -, de forma que a decisão acerca desse objeto será igualmente unitária, “tornando desnecessária uma 'segunda' ação coletiva para o mesmo fim" ${ }^{412}$. Em adição, chama a atenção para o fato de que referidas demandas, por tutelarem um interesse tipicamente difuso, terão decisões com eficácia erga omnes, de tal sorte que "o andamento separado de processos coletivos engendra o risco virtual de decisões de mérito em sentido discrepante", criando um ambiente processual caótico e paradoxal $^{413}$.

Embora reconheça as graves conseqüências da concomitância de ações coletivas com o mesmo objetivo, MANCUSO sustenta que o ajuizamento de uma ação coletiva não induz litispendência a outras ações coletivas, pois não há como impedir que outro colegitimado venha a exercer seu direito de ofertar uma segunda ação coletiva. Isso por conta da legitimação concorrente-disjuntiva (todos os credenciados podem agir juntos ou separadamente: art. 5\%, LACP) e da garantia de acesso ao Judiciário. Daí porque "não há como sustentar que a ação primeiro ajuizada seja impeditiva e excludente de possíveis outras" ${ }^{\prime 414}$. Ao admitir essa possibilidade, o autor reconhece que naturalmente se estaria aceitando a virtual concorrência de mais de uma ação de tipo coletivo, envolvendo análogo objeto, o que, todavia, pode ser solucionado pelos institutos da conexão, da continência e

\footnotetext{
${ }^{410}$ Nesse sentido, MANCUSO, Rodolfo de Camargo. A concomitância entre ações de natureza coletiva. $O p$. cit., p. 164.

${ }^{411}$ Idem. Transposição das águas do Rio São Francisco: uma abordagem jurídica da controvérsia. In Ação Civil Pública após 20 anos: efetividade e desafios. MILARÉ, Édis (Coord.). São Paulo: Revista dos Tribunais, 2005, p. 553, passim.

${ }^{412}$ Idem. Transposição..., op. cit., p. 553.

${ }^{413}$ Idem, ibidem.

${ }^{414}$ Idem, ibidem, p. 555.
} 
da prevenção, “deixando-se para os casos extremos, em que seja marcante a superposição entre causas e pedidos (...) a litispendência»"415.

A partir dessa abordagem, o autor conclui que:

Há que conviver com a virtualidade do ajuizamento de mais de um feito de natureza coletiva sobre um mesmo thema decidendum; todavia, ante o risco virtual de prolação de decisões discrepantes, que a partir de certo momento ficarão acobertadas por coisas julgadas de eficácia expandida, há que diligenciar para que tal imbricação não engendre situações processualmente (e praticamente) caóticas. Para tanto, tais ações devem ser reunidas por conexão (identidade da causa ou do pedido) para julgamento conjunto no órgão judicial que primeiro tenha oficiado e que assim ficou prevento (CPC, arts. 103, 105 e 106) ${ }^{416}$.

No entanto, é possível discordar do argumento segundo o qual "não há como impedir que outro co-legitimado venha a exercer seu direito de ofertar uma segunda ação coletiva (...) por conta da legitimação concorrente-disjuntiva”. Concessa venia, entendemos que o artigo $5^{\circ}$ da LACP não confere um direito às pessoas ali relacionadas; 0 titular do direito de ação é, sempre, a coletividade. A legitimação é concorrente e disjuntiva no sentido de que não há uma ordem de preferência. São todos igualmente legitimados. Justamente por isso, um deles agindo significa que a coletividade já agiu, tornando-se desnecessária a atuação de qualquer outro.

O fato de a lei ter legitimado mais de uma pessoa para defender os interesses da sociedade não significa que todos eles poderão agir dissociada e concomitantemente na defesa do mesmo bem jurídico coletivo. Em verdade, aquele que propuser a primeira ação estará, com isso, esvaziando o interesse dos demais legitimados para agir autonomamente na defesa daquele bem jurídico coletivo. Isso não retira nem diminui a legitimação conferida pela Lei a todas aquelas pessoas citadas no artigo $5^{\circ}$. Elas continuam sendo absolutamente legítimas para intentar ações na defesa de outros bens coletivos ou intervir no processo já proposto para a defesa daquele bem jurídico específico.

\footnotetext{
${ }^{415}$ MANCUSO, Rodolfo de Camargo. Transposição..., op. cit., p. 554.

${ }^{416}$ Idem, ibidem, p. 556.
} 
Nesse sentido, vale recordar o que discorreu ARRUDA ALVIM acerca da legitimação concorrente: "mais de uma pessoa pode usar da mesma ação para idêntico fim. A que ajuizar a ação em primeiro lugar exclui a ação idêntica das demais, conquanto não haja identidade física” ${ }^{\natural 17}$. Portanto, não só é possível, como é recomendável impedir que outro co-legitimado proponha a segunda ação para tutelar o mesmo bem jurídico. Se não há como prevenir isso, que, ao menos, corrija-se o mais brevemente possível, extinguindose a segunda a ação - assim, privilegia-se o objetivo maior da jurisdição coletiva, que é a molecularização.

Com efeito, há de se convir: se rigidamente interpretada, a conexão leva à proliferação de ações coletivas e à multiplicação de decisões contraditórias ${ }^{418}$. Daí porque se entende que a propositura da primeira demanda coletiva induz à litispendência, sendo facultado aos demais co-legitimados habilitarem-se no pólo ativo daquela primeira ação, como assistentes litisconsorciais ${ }^{419}$, conforme se verá mais adiante.

A esse respeito, WATANABE salienta que, para as "causas" que tenham como causa de pedir interesses difusos ou coletivos e como pedido a tutela desses interesses indivisíveis,

\footnotetext{
É suficiente uma só demanda coletiva. (...) Não faz qualquer sentido admitir-se uma segunda demanda para a tutela desses interesses ou direitos difusos ou coletivos, ou mesmo interesses ou direitos individuais homogêneos. (...) De pronto é constatável a ocorrência de litispendência ${ }^{420}$.
}

Adiante, o autor exemplifica com o caso de diversas demandas 'coletivas' propostas nos vários Estados em favor de aposentados e que constituem repetição da primeira demanda coletiva proposta para o mesmo fim (rectius: litispendência) ${ }^{421}$.

\footnotetext{
${ }^{417}$ ARRUDA ALVIM. Ensaio..., op. cit., v. II, p. 67 (g.n.).

${ }^{418}$ GRINOVER, Ada Pellegrini. Rumo a um Código Brasileiro de Processos Coletivos - Exposição de Motivos. In Tutela Coletiva: 20 anos da Ação Civil Pública e Fundo de Defesa de Direitos Difusos, 15 anos do Código de Defesa do Consumidor. LUCON, Paulo Henrique dos Santos (Coord.). São Paulo: Atlas, 2006, p. 2 (g.n.).

${ }^{419}$ Cf. GIDI, Antonio, Rumo..., op. cit., p. 313. A expressão "tomar o seu lugar" é uma alusão ao controle judicial da representação adequada.

${ }^{420}$ WATANABE, Kazuo. Demandas coletivas e os problemas emergentes da práxis forense. Revista de Processo n. 67. São Paulo: Revista dos Tribunais, jul.-set. 1992, p. 18/19 (g.n.).

${ }^{421}$ Idem, ibidem.
} 
Em situações como essa, ARRUDA ALVIM já ensinava caber ao juiz aprofundarse no exame da relação jurídica deduzida em juízo nas duas ações e, entendendo que são idênticas, como também as conseqüências jurídicas pedidas, obstar a segunda demanda ${ }^{422}$.

A reiterar tal entendimento, MENDES lembra que:

Estando em jogo o mesmo pedido e causa de pedir, bem como havendo coincidência entre os titulares dos interesses difusos e coletivos, não se deve admitir o ajuizamento de nova ação coletiva, em razão de litispendência. Outras soluções, como a reunião de processos, sob o argumento da conexão ou da continência, além de tecnicamente incabíveis diante da identidade objetiva, muito provavelmente acabariam ocasionando tumulto processual e retardamento no julgamento da demanda coletiva ${ }^{423}$.

Por seu turno, WAMBIER entende que o art. $5^{\circ}, \S 3^{\circ}$, da Lei da Ação Popular não pode ser entendido como um 'permissivo legal' para que "nas ações coletivas atuais se entenda, como regra geral, que pode haver litispendência e que as ações idênticas devem ser pura e simplesmente reunidas, não devendo a segunda ser extinta» ${ }^{424}$.

De certa forma, a opção pela conexão, nesses casos, equivaleria a uma permissão para que fossem ajuizadas inúmeras ações coletivas com o mesmo objeto, o que, além de ser anti-econômico, é perigoso, pois, como bem observado por VENTURI, o processamento de mais de uma demanda coletiva versando sobre idênticas pretensões (sobretudo quando elas não são sequer reunidas perante o mesmo juízo para processamento e julgamento simultâneos) favorece a multiplicação de feitos coletivos e conseqüentes decisões contraditórias, além de desvirtuar a lógica e a própria ideologia do sistema de tutela coletiva no que diz respeito ao significado da abrangência erga omnes ou ultra partes do julgamento ${ }^{425}$.

\footnotetext{
${ }^{422}$ ARRUDA ALVIM. Ensaio..., op. cit., v. II, p. 103 (g.n.).

${ }^{423}$ MENDES, Aluísio Gonçalves de Castro. Ações coletivas no direito comparado e nacional. São Paulo: Revista dos Tribunais, 2002, p. 260.

${ }^{424}$ WAMBIER, Teresa Arruda Alvim. Litispendência em ações coletivas. In Processo Civil Coletivo. MAZZEI, Rodrigo e NOLASCO, Rita Dias (Coords.). São Paulo: Quartier Latin, 2005, p. 294.

${ }^{425}$ VENTURI, Elton. Processo..., op. cit., p. 334.
} 
Precisa, no particular, a advertência de MATTOS, no sentido de que:

O processamento conjunto de ações repetidas não acarreta qualquer vantagem para a eficiente prestação jurisdicional. Ao contrário, atenta contra os princípios da economia processual e da instrumentalidade das formas, pois duplica o dispêndio de atividade processual, energias, dinheiro e tempo e retarda a entrega da tutela jurisdicional quando ela é prioritária $^{426}$.

Esta também a posição de GIDI, para quem

A proposta de reunião dos processos (idênticos ou conexos) complicará ainda mais os processos coletivos, multiplicando desnecessariamente o número de autos independentes, principalmente se houver um número grande de processos coletivos (...) com o mesmo objeto ou objetos semelhantes e sobrepostos. Reuni-los todos em um único juízo não somente é desnecessário e anti-econômico como impraticável. O juízo prevento terá que decidir dezenas de processos com pedidos, causa de pedir, elementos probatórios semelhantes e sobrepostos, mas não necessariamente iguais ${ }^{427}$.

Em resumo, pode-se dizer que a vedação de dois processos tendentes a obter o mesmo resultado ou solucionar o mesmo conflito de interesses justifica-se tanto pelo princípio da economia processual, quanto pelo fato de afastar a possibilidade de decisões conflitantes, que comprometeriam a credibilidade, o prestígio e a autoridade do Poder Judiciário, provocando incertezas no meio social; isso sem falar no impedimento à realização do direito da parte, “em razão da dificuldade de determinar qual julgado deveria prevalecer" ${ }^{\prime 28}$.

\footnotetext{
${ }^{426}$ MATTOS, Luiz Norton Baptista de. A litispendência e a coisa julgada nas ações coletivas segundo o Código de Defesa do Consumidor e os anteprojetos do Código Brasileiro de Processos Coletivos. In Direito Processual Coletivo e o Anteprojeto de Código Brasileiro de Processos Coletivos. GRINOVER, Ada Pellegrini, MENDES, Aluisio Gonçalves de Castro e WATANABE, Kazuo (Coords.). São Paulo: Revista dos Tribunais, 2007, p. 199 (g.n.).

${ }^{427}$ GIDI, Antonio. Rumo ..., op. cit., p. 313/314.

${ }^{428}$ MATTOS, Luiz Norton Baptista de. Ibidem, p. 195.
} 
Assim, pode-se concluir, no que tange à litispendência entre ações coletivas, que “deve-se dispensar a exigência de uma exata identidade entre os elementos (partes, pedido e causa - os 'tria eadem') das ações comparadas"429.

Um exemplo pode ilustrar e confirmar essa conclusão. Ao examinar se a insurgência de duas entidades de defesa do meio ambiente, contra a degradação de um manancial causada por uma empresa, configuraria conexão ou litispendência, CRUZ E TUCCI conclui que "em situações de aparente conexão, o que na realidade ocorre é outro fenômeno de maior amplitude (verdadeira litispendência)" ${ }^{\text {,30 }}$, tomando por base a seguinte linha de raciocínio:

Estaríamos diante de situação de mera conexão de ações, a determinar que fossem elas reunidas para julgamento numa única ocasião? Caso levássemos em consideração estritamente o conceito previsto no art. 103 e seguintes do Código de Processo Civil, chegaríamos à solução de que seriam ações conexas, com a solução preconizada no art. 105. Portanto, insuficiente o conceito legal para a correta solução da hipótese. (...) Como equacionar a questão? A insuficiência de interação, nesse caso, da definição legal da conexão com fundamento causa petendi e dos elementos de identificação das ações implicaria a aceitação de que, na hipótese, a causa deveria ser interpretada como identidade de relação jurídica substancial, ainda que entre pessoas distintas, mas providas da mesma condição jurídica (parte em sentido material). Isso resultaria no reconhecimento de que em verdade seriam duas ações idênticas e a solução seria a extinção da demanda aforada posteriormente, em virtude da ocorrência do fenômeno da litispendência ${ }^{431}$.

Por fim, cabe reconhecer que a opção pela litispendência, com a extinção das demandas repetidas requer, em um país de dimensões continentais com o Brasil, maior instrumentalização da comunicação de processos, como a instituição do Cadastro Nacional

\footnotetext{
${ }^{429}$ MANCUSO, Rodolfo de Camargo. Jurisdição coletiva ..., op. cit., p. 108 (g.n.).

${ }^{430}$ CRUZ E TUCCI, José Rogério. A causa petendi no processo civil. São Paulo: Revista dos Tribunais, 2001, p. 222/223.

${ }^{431}$ Idem, ibidem, p. 222/223 (g.n.).
} 
de Ações Coletivas, contemplado tanto no ANTEPROJETO DA USP ${ }^{432}$ quanto na PROPOSTA DO MiNisTÉRIO DA JUSTIÇA/SECRETARIA DE REFORMA DO JUDICIÁRIO ${ }^{433}$.

\section{IV.1.2.1. Molecularização = uma única demanda}

Em reforço à idéia acima desenvolvida, é cabível uma digressão à própria finalidade das ações coletivas.

Para tanto, vale lembrar que, com o advento da Constituição Federal de 1988, o Brasil passou a assistir a uma verdadeira ampliação do acesso à justiça ao longo das últimas duas décadas. Se essa ampliação foi salutar, por um lado, pois democratizou o acesso ao Poder Judiciário, conferindo maior relevância ao escopo social do processo, por outro, acabou acarretando sobrecarga de trabalho aos magistrados, que, devido ao grande número de processos e à falta de estrutura, não mais conseguiam prestar uma tutela jurisdicional efetiva e de qualidade, isto é, dotada das seguintes características: justa, jurídica, econômica, tempestiva e razoavelmente previsível ${ }^{434}$.

432 “Art. 46. Do Cadastro Nacional de Processos Coletivos - O Conselho Nacional de Justiça organizará e manterá o Cadastro Nacional de Processos Coletivos, com a finalidade de permitir que todos os órgãos do Poder Judiciário e todos os interessados tenham acesso ao conhecimento da existência de ações coletivas, facilitando a sua publicidade.

$\S 1^{\circ}$. Os órgãos judiciários aos quais forem distribuídos processos coletivos remeterão, no prazo de 10 (dez) dias, cópia da petição inicial ao Cadastro Nacional de Processos Coletivos.

$\S 2^{\circ}$. O Conselho Nacional de Justiça, no prazo de 90 (noventa) dias, editará regulamento dispondo sobre o funcionamento do Cadastro Nacional de Processos Coletivos, incluindo a forma de comunicação pelos juízos quanto à existência de processos coletivos e aos atos processuais mais relevantes, como a concessão de antecipação de tutela, a sentença e o trânsito em julgado, a interposição de recursos e seu andamento, a execução provisória ou definitiva; disciplinará, ainda, os meios adequados a viabilizar o acesso aos dados e seu acompanhamento por qualquer interessado".

433 “Art. 43. O Conselho Nacional de Justiça organizará e manterá o Cadastro Nacional de Processos Coletivos, com a finalidade de permitir que os órgãos do Poder Judiciário e os interessados tenham amplo acesso às informações relevantes relacionadas com a existência e o estado das ações coletivas.

$\S 1^{\circ}$. Os órgãos judiciários aos quais forem distribuídos processos coletivos remeterão, no prazo de 10 (dez) dias, cópia da petição inicial, preferencialmente por meio eletrônico, ao Cadastro Nacional de Processos Coletivos.

$\S 2^{\circ}$. No prazo de 90 (noventa) dias, o Conselho Nacional de Justiça, editará regulamento dispondo sobre o funcionamento do Cadastro Nacional de Processos Coletivos e os meios adequados a viabilizar o acesso aos dados e seu acompanhamento por qualquer interessado através da rede mundial de computadores. $\mathrm{O}$ regulamento disciplinará a forma através da qual os juízos comunicarão a existência de processos coletivos e os atos processuais mais relevantes sobre o seu andamento, como a concessão de antecipação de tutela, a sentença, o trânsito em julgado, a interposição de recursos e a execução".

${ }^{434}$ Cf. MANCUSO, Rodolfo de Camargo. A concomitância entre ações de natureza coletiva. Op. cit., p. 162. 
Em certa medida, a crise do Judiciário, por todos sentida e percebida, deve-se ao acúmulo de ações repetitivas, versando sobre a mesma questão de fundo. Nesse cenário, ganham importância as ações que tratam de forma molecular possíveis demandas-átomo. Com efeito, as ações coletivas são uma das formas de contribuir-se para a superação da crise do Judiciário $^{435}$, na medida em que centenas ou milhares de conflitos idênticos podem ser resolvidos em uma única demanda.

Na precisa lição de MANCUSO, a finalidade da jurisdição coletiva não é outra senão "potencializar a resposta judiciária, por modo que um só comando possa resolver o conflito metaindividual em modo unitário e isonômico" "436. Com isso, estar-se-á prevenindo "os malefícios de sua pulverização em multifárias demandas individuais [e] o risco de decisões contraditórias sobre um mesmo thema decidendum"437.

Dentre as vantagens da tutela processual coletiva, pode-se destacar o princípio da economia processual, uma vez que, “com apenas uma decisão, o Poder Judiciário resolve controvérsia que demandaria uma infinidade de sentenças individuais. Isso faz o Judiciário mais ágil’ ${ }^{, 38}$ e as relações mais seguras. Daí se dizer que:

Ao original thema decidendum podem se agregar outros pontos conflituosos, na esteira da desejável jurisdição integral, pela qual num mesmo processo fica resolvida a demanda-núcleo e também os demais pontos conflitivos periféricos, que, de outro modo, ficariam em aberto, podendo engendrar futuras lides em outros $\operatorname{processos}^{439}$.

\footnotetext{
${ }^{435}$ Outra resposta à crise está nos novos mecanismos de contenção de recursos nos Tribunais Superiores, instituídos pela Emenda Constitucional 45/2004 e pelas Leis 11.276/06 (súmula impeditiva de recurso), 11.277/06 (precedentes do juízo monocrático), 11.417/06 (súmula vinculante), 11.418/06 (repercussão geral) e 11.672/08 (recursos repetitivos no STJ).

${ }^{436}$ MANCUSO, Rodolfo de Camargo. A concomitância entre ações de natureza coletiva. Op. cit., p. 162 (g.n.).

${ }^{437}$ Idem, ibidem.

${ }^{438}$ Trecho da ementa - MS 5.187/DF, rel. Min. Humberto Gomes de Barros, DJU 29.06.1998. Apud ARRUDA ALVIM, Eduardo. Coisa julgada..., op. cit., p. 175.

${ }^{439}$ MANCUSO, Rodolfo de Camargo. Ibidem, p. 165.
} 
Em reforço a essas idéias, MANCUSO entende ser "intolerável a atomização do conflito coletivo, fracionado em inúmeras demandas individuais múltiplas e repetitivas, ensejando julgamentos discrepantes ou mesmo contraditórios sobre um mesmo tema”,440. Para o autor, essa situação configura "uma sorte de inconstitucionalidade, se considerado que o princípio de igualdade de todos perante a lei $\left(\mathrm{CF}\right.$, art. $5^{\circ}$, caput) estabelece uma isonomia substancial ${ }^{, 441}$.

Seguindo essa mesma linha de raciocínio, GOMES JR. enfatiza que:

Se duas decisões judiciais, analisando uma mesma situação fática, submetida a idêntica disciplina jurídica, produzem resultados opostos, uma delas, conseqüentemente, violou o Princípio Constitucional da Igualdade (art. $5^{\circ}$, caput da CF-88) sendo, portanto, inconstitucional" ${ }^{\text {"42. }}$. Com efeito, "o processo coletivo só se justifica se através dele se puder alcançar uma resposta isonômica que resolva 'molecularmente' o conflito (...), sem deixar resíduos conflituosos que na seqüência darão azo a novas lides, num perverso ciclo vicioso ${ }^{443}$.

Se é isso que se espera das ações coletivas, se é essa a missão que lhes foi dada, é preciso fornecer-lhes instrumentos que permitam o bom desempenho dessa função, dotando o processo coletivo de poderes mais amplos e, muitas vezes, mais flexíveis. Afinal, a multiplicidade de demandas coletivas versando sobre o mesmo thema decidendum é intolerável e pode gerar problemas gravíssimos, especialmente em se tratando de interesses difusos, dada a incindibilidade (absoluta) do objeto ${ }^{444}$.

\footnotetext{
${ }^{440}$ Conforme MANCUSO, Rodolfo de Camargo. A concomitância de ações coletivas, entre si, e em face das ações individuais. In Revista dos Tribunais, ano 89, v. 782, São Paulo, dez. 2000, p. 46. Em sentido oposto, Teresa Arruda Alvim WAMBIER defende que "não é garantia constitucional o compromisso absoluto de acabar com o fenômeno das decisões contraditórias" (In Litispendência em ações coletivas. In Processo Civil Coletivo. MAZZEI, Rodrigo e NOLASCO, Rita Dias (Coords.). São Paulo: Quartier Latin, 2005, p. 285).

${ }^{441}$ MANCUSO, Rodolfo de Camargo. Ibidem.

${ }^{442}$ GOMES JR., Luiz Manoel. Curso..., op. cit., p. 187.

${ }^{443}$ MANCUSO, Rodolfo de Camargo. Jurisdição Coletiva e Coisa Julgada - Teoria Geral das Ações Coletivas. São Paulo: Revista dos Tribunais, 2006, p. 108 (g.n.).

${ }^{444}$ A incindibilidade é absoluta em função da própria indeterminação das pessoas que compõem a comunidade titular do direito (Cf. MANSUCO, Rodolfo de Camargo. Comentários ao Código de Defesa do Consumidor. São Paulo: Saraiva, 1991, p. 276; e GIDI, Antonio. Coisa julgada..., op. cit., p. 28).
} 
Não por outro motivo, WATANABE afirma que para a tutela dos interesses difusos (que, pela sua própria natureza, deve ser feita molecularmente), "será suficiente uma só demanda coletiva, cuja sentença, nos termos do artigo 103, I [do CDC], fará coisa julgada erga omnes" ${ }^{\prime 45}$. Nesse mesmo sentido, MENDES demonstra que, em função da indivisibilidade do objeto, "os interesses difusos e coletivos não comportam - material ou logicamente - a convivência de várias ações, diante de pretensões e fundamentos idênticos"446. Isso pela simples razão de que a emissão de pronunciamentos judiciais contraditórios poderia estabelecer padrões de conduta incompatíveis entre si.

Por certo, admitir o processamento simultâneo de duas ações coletivas com o mesmo fim pode chegar a um de dois resultados possíveis: (i) na melhor hipótese, ambas as decisões seriam no mesmo sentido, o que tornaria a segunda demanda totalmente supérflua; e (ii) na pior hipótese, as decisões seriam opostas, ambas com efeitos erga omnes, gerando contradição prática e não apenas lógica de julgados.

Nas palavras de ARRUDA ALVIM:

Havendo duplicidade de litispendências idênticas, ou se proferem duas decisões idênticas, o que infringiria obviamente a economia da atividade jurisdicional, ou elas seriam contraditórias, o que, além do primeiro aspecto, traria problemas mais graves a serem dificilmente solucionados. Normalmente, obsta-se esse perigo pela eliminação de um dos $\operatorname{processos}^{447}$.

GRINOVER corrobora esse entendimento ao ressaltar que, no caso de identidade do bem jurídico coletivo tutelado, não é possível o prosseguimento de ambas as ações, tendo em vista a possibilidade de surgirem decisões contraditórias, com coisas julgadas não só logicamente inconciliáveis, mas praticamente incompatíveis.

\footnotetext{
${ }^{445}$ WATANABE, Kazuo. Comentários ao artigo 81, CDC. Código Brasileiro de Defesa..., op. cit., p. 803. ${ }^{446}$ MENDES, Aluísio Gonçalves de Castro. Ações coletivas..., op. cit., p. 260 (g.n.).

${ }^{447}$ ARRUDA ALVIM. Direito Processual Civil - Teoria Geral do Processo de Conhecimento. São Paulo: Revista dos Tribunais, 1972, p. 76/77.
} 
Diante deste quadro, questiona a autora: “como poderiam, autores e réus, atender a dois julgados, quando um acolhesse o pedido de declaração de nulidade do ato de nomeação e o outro considerasse válido o mesmo ato?"448.

Em razão da dificuldade de determinar qual julgado deva prevalecer, pode-se chegar ao ponto de impedir-se a própria realização do direito da parte ${ }^{449}$. A bem ver, portanto, a unidade da convicção favorece a efetividade do processo coletivo, atingindo-se o escopo do processo, de pacificar com justiça. Assim, em homenagem aos princípios da economia processual, da isonomia e da certeza das relações jurídicas, há que se dotar o sistema processual coletivo de instrumentos aptos a resolver os problemas decorrentes da relação entre demandas coletivas.

É preciso, pois, contribuir para que a jurisdição coletiva forneça uma resposta judiciária justa, econômica e tempestiva a toda a sociedade, evitando-se a propositura de reiteradas ações, "com o que ganham as partes em celeridade, ganha a sociedade, que se vê aliviada de numerosas lides, e ganha o Poder Judiciário ao distribuir uma justiça mais rápida e homogênea, afastando o risco de decisões contraditórias em casos análogos" ${ }^{\text {450 }}$.

Por isso, ANTEPROJETO DA USP (art. $7^{\circ}$ ) e a PROPOSTA DO MINISTÉRIO DA JustiçA/SECRETARIA DE REFORMA DO JUdiCIÁRIO (art. $8^{\circ}, \S 2^{\circ}$ ) determinam que, havendo diversos processos individuais correndo contra o mesmo demandado, com identidade de fundamento jurídico, o juiz notificará os legitimados ativos a fim de que proponham demanda coletiva. Essa solução vai ao encontro do próprio espírito do processo civil coletivo, no sentido de que uma única ação coletiva pode substituir múltiplas ações individuais, trazendo maior celeridade e diminuindo o risco de decisões conflitantes.

\footnotetext{
${ }^{448}$ GRINOVER, Ada Pellegrini. Uma nova modalidade de legitimação à ação popular. Possibilidade de conexão, continência e litispendência. In Ação Civil Pública - reminiscências e reflexões após 10 anos de aplicação. MILARÉ, Édis (Coord.). São Paulo: Revista dos Tribunais, 1995, p. 27.

${ }_{449}^{4}$ MATTOS, Luiz Norton Baptista de. A litispendência..., op. cit., p. 195.

${ }^{450}$ MANCUSO, Rodolfo de Camargo. Uma análise comparativa entre os objetos e as legitimações ativas das ações vocacionadas à tutela dos interesses metaindividuais: Mandado de Segurança Coletivo, Ação Civil Pública, Ações do Código de Defesa do Consumidor e Ação Popular. Justitia, São Paulo, 54 (160), out.-dez. 1992 (g.n.).
} 
A propósito, é possível identificar uma convergência de interesses/finalidade entre o espírito das ações coletivas e o espírito da própria litispendência. Ambos os instrumentos estão a serviço do mesmo fim: evitar o bis in idem. As ações coletivas atingem tal objetivo quando resolvem, com um só comando, de modo unitário e isonômico, conflitos que atingem uma multiplicidade de pessoas, e a litispendência o faz quando previne a prolação de decisões conflitantes sobre o mesmo objeto. Ademais, a litispendência tem como finalidade "abreviar a duração dos processos, (...) otimizar a eficiência da resposta judiciária, e, sobremodo, evitar as discrepâncias entre os julgados" ${ }^{\text {"451 }}$. Nesse contexto cabe indagar se não são esses, justamente, os objetivos da própria jurisdição coletiva.

\section{IV.1.2.2. Proposta de solução: possibilidade de ampliação da primeira demanda}

Diante das drásticas conseqüências advindas da opção de extinguirem-se as demandas subseqüentes, pode-se aventar (em contrapartida) uma possibilidade de ampliação da demanda proposta em primeiro lugar - até para não privilegiar o 'afoito', em detrimento da efetiva tutela dos interesses metaindividuais. Isso porque nem sempre aquele legitimado que foi o mais rápido no ajuizamento da demanda é o representante mais adequado do grupo ou da sociedade. $\mathrm{Ou}$, pior, pode haver conluio entre autor e réu, com vistas a impedir a propositura de demandas de melhor nível.

Embora não se deva legislar pensando na exceção, é certo que o legislador pátrio preocupou-se com os abusos, como se vê no artigo $5^{\circ}, \S 2^{\circ}$, da LACP, que faculta ao Poder Público e às associações a habilitação como litisconsorte de quaisquer das partes. Ao examinar o sistema hoje existente, MANCUSO admite a formação de um litisconsórcio ulterior, decorrente do ingresso de um co-legitimado ativo na ação já proposta, mas destaca que, nesse caso, o que ocorre é uma verdadeira 'intervenção litisconsorcial voluntária'452 e 453

\footnotetext{
${ }^{451}$ MANCUSO, Rodolfo de Camargo. Ação Civil Pública..., op. cit., p. 233.

${ }^{452}$ DINAMARCO, Cândido Rangel. Litisconsórcio. São Paulo: Malheiros, 2002, p. 333. Apud MANCUSO, Rodolfo de Camargo. Ibidem, p. 217.

453 Por analogia à Lei da Ação Popular (que, de forma mais ampla, permite a qualquer cidadão "habilitar-se como litisconsorte ou assistente do autor da ação popular", cf. artigo $6^{\circ}, \S 5^{\circ}$ ), pode-se cogitar, ainda, da assistência simples em sede de ações civis públicas, sendo que, nesta hipótese, diferentemente do
} 
Assim, não há como negar a admissão, no pólo ativo, dos demais legitimados interessados na tutela daquele mesmo bem jurídico - em especial, aqueles que tiveram suas demandas extintas pela litispendência -, na qualidade de litisconsortes ulteriores (assistentes litisconsorciais). Aos litisconsortes seria permitido promover a "melhoria" da ação, trazendo novos elementos à ação, modificando os elementos objetivos da demanda, desde que se observe o contraditório e a ampla defesa. No caso de haver discordância entre os co-autores, caberá ao juiz decidir quanto ao deferimento ou não do aditamento à inicial e, em caso positivo, resguardar o direito à ampla defesa e ao contraditório da parte contrária.

É o que admite GIDI, para quem

Em vez de reunir os diversos processos coletivos, o mais adequado seria seguir a norma tradicional do processo civil individual de manter o primeiro processo e extinguir os demais (...), autorizando-se, claro, os autores dos processos coletivos extintos a intervir no primeiro processo e a trabalhar colaborativamente em um único processo, apresentando novos pedidos, causas de pedir, provas e argumentos se preciso (...), desde que não haja desnecessária repetição de atos processuais ${ }^{454}$.

É bem verdade que, se o número de legitimados ativos for tal que configure o litisconsórcio multitudinário, o juiz poderá indeferir novos pedidos de ingresso ${ }^{455}$. Nem por isso estar-se-á pondo em risco o interesse da coletividade: a uma, porque o interesse coletivo já estará suficientemente tutelado; a duas, porque "o direito não socorre os que dormem".

litisconsórcio (assistência litisconsorcial), o assistente não terá amplos poderes para agir mesmo em desconformidade com a vontade do autor original.

${ }^{454}$ GIDI, Antonio. Rumo ..., op. cit., p. 313/314.

${ }^{455}$ Nesse sentido, a PROPOSTA DO MINISTÉRIO DA JustiÇA/SECRETARIA DE REFORMA DO JUdiCIÁRIO dispõe que "Art. $10, \S 1^{\circ}$. O juiz rejeitará liminarmente o pedido de habilitação como assistente, do membro do grupo, na ação em defesa de interesses ou direitos individuais homogêneos, quando o interessado não demonstrar, de plano, razões de fato ou de direito que assegurem utilidade à tutela coletiva e justifiquem a sua intervenção, podendo o juiz limitar o número de assistentes, quando este comprometer o bom andamento e a duração razoável do processo". 
A solução de admitir, no pólo ativo, os demais legitimados interessados amenizaria a preocupação de alguns doutrinadores quanto a perder-se a oportunidade de analisar iniciais de melhor nível, caso a primeira ação não tenha sido bem proposta, pois seria permitido aos demais co-legitimados corrigir ou melhorar a ação remanescente. Com isso, o sistema não estaria, pura e simplesmente, privilegiando o 'afoito'. Portanto, como bem enfatiza NORTON, os autores do processo extinto sempre poderão intervir no processo inicial como litisconsortes, suprindo omissões do autor originário, o que afasta o argumento de que uma atuação mais expedita ou diligente de um dos representantes cercearia o acesso dos demais à justiça, limitando sua influência na proteção ao direito difuso ou coletivo ${ }^{456}$.

\section{IV.1.2.3. Nova equação das regras de estabilização da demanda}

Nessa esteira, cumpre salientar que as regras de estabilização da demanda (preclusão + eventualidade) devem considerar as melhores opções em busca da celeridade e da segurança jurídica, de acordo com a espécie de interesse jurídico submetido ao Judiciário.

Vale lembrar o que dispõe o $\mathrm{CPC}$ a respeito:

Quanto à alteração do pedido - isto é, à substituição do pedido originário por outro -, a lei a faculta: a) antes de citado o réu, pela simples manifestação do autor (art. 264, caput, a contrario sensu); b) após a citação (mas nunca depois de saneado o processo: art. 264, parágrafo único), mediante o consentimento do réu (...). Ao réu, naturalmente, há de assegurar-se novo prazo para resposta, pois, alterado o pedido, a ação passa a ser diversa (art. 301, $\S 2^{\circ}$, a contrario sensu $)^{457}$.

\footnotetext{
${ }^{456}$ MATTOS, Luiz Norton Baptista de. A litispendência..., op. cit., p. 199.

457 BARBOSA MOREIRA, José Carlos. O novo processo civil brasileiro: exposição sistemática do procedimento. Rio de Janeiro: Forense, 1999, p. 13.
} 
De outro lado, vige no direito brasileiro a regra da eventualidade, segundo a qual autor e réu devem alegar, em um mesmo momento, todos os meios de ataque e defesa, ainda que contraditórios entre si (artigos 264 e 294, CPC) ${ }^{458}$. Tal regra impõe um sistema rígido de preclusões, a ponto de "passada em julgado uma sentença de mérito, reputar-seão deduzidas e repelidas todas as alegações e defesas, que a parte poderia opor assim ao acolhimento como à rejeição do pedido" (art. 474, CPC).

A partir da análise do sistema processual civil tradicional, GIDI propõe "o repensar das vetustas normas de preclusão e do princípio da eventualidade, fugindo de um sistema rígido para um sistema flexível de estabilização da demanda" ${ }^{459}$. Por seu turno, LEONEL posiciona-se a favor de um meio-termo entre a rigidez excessiva e a flexibilização total, ponderando que: “um sistema rígido favorece a solução mais rápida $d a$ ação, mas não obrigatoriamente do conflito adjacente" 460 .

Embora o legislador de 1973 tenha optado por um modelo rígido de processo, é de reconhecer-se, na esteira de LEONEL, que:

\begin{abstract}
Pelas peculiaridades do processo coletivo, considerando o dinamismo das respectivas situações de direito material (característica marcante dos interesses difusos, coletivos e individuais homogêneos), é possível afirmar que a solução mais apropriada passa pelo caminho da
\end{abstract} flexibilização da estabilização da causa de pedir e do pedido nas demandas coletivas ${ }^{461}$.

A partir dessa constatação, cabe indagar: o que é preferível, celeridade do processo ou da solução definitiva da controvérsia? A esse respeito, CHIOVENDA pondera que o princípio da economia processual recomenda a sua utilização o máximo possível,

\footnotetext{
${ }^{458}$ LIEBMAN, Enrico Tullio (Notas). In CHIOVENDA, Giuseppe. Instituições de Direito Processual Civil. MENEGALE, J. Guimarães (Trad.). São Paulo: Saraiva, 1965, v. III, p. 158. Apud CRUZ E TUCCI, José Rogério. A causa petendi..., op. cit., p. 148.

${ }_{459}$ GIDI, Antonio. Rumo..., op. cit., p. 48 (g.n.).

${ }^{460}$ LEONEL, Ricardo de Barros. Causa de pedir e pedido nos processos coletivos: uma nova equação para a estabilização da demanda. In Direito Processual Coletivo e o Anteprojeto de Código Brasileiro de Processos Coletivos. GRINOVER, Ada Pellegrini, MENDES, Aluisio Gonçalves de Castro e WATANABE, Kazuo (Coords.). São Paulo: Revista dos Tribunais, 2007, p. 148.

${ }^{461}$ LEONEL, Ricardo de Barros. Ibidem (g.n.).
} 
favorecendo a mudança da demanda. O autor, em passagem já citada no Capítulo I, lembra que os legisladores austríaco e alemão foram levados a "sacrificar os rigorosos princípios da identificação das ações, admitindo que possa mudar-se a demanda quando o magistrado julga que a defesa do réu não seja substancialmente agravada"462.

Quanto aos elementos pedido e causa de pedir, por exemplo, GRINOVER salienta que "o conceito rígido de pedido e causa de pedir, próprio do processo individual, aplicado ao processo coletivo, tem dificultado, no Brasil, a reunião de processos, provocando a condução fragmentária de demandas, com decisões contraditórias" ${ }^{\text {"463 }}$. Nesse sentido, é preferível flexibilizar e permitir a modificação da demanda, com vistas a eliminar a crise de direito, em vez de aplicar extremo rigor na estabilização da demanda e provocar novas demandas coletivas. A título de exemplo, cite-se a modernização do processo civil português, que admitiu a alteração dos elementos objetivos da demanda, em determinadas situações e sob certas condições, com vistas a prestigiar a efetividade do processo (isto é, obtenção do máximo de resultado em cada processo, resolvendo-se de forma integral o litígio).

A bem ver, a maior flexibilização da técnica processual, considerando o direito material controvertido, pode significar importante avanço rumo à instrumentalidade e à efetividade do processo. Com isso, busca-se solucionar numa só ação toda a crise de direito material. Ou, nas palavras de LEONEL, a flexibilidade das regras de estabilização da demanda atende à finalidade de "numa só relação processual instaurada seja viável equacionar definitivamente o conflito" 464 .

Com relação ao dinamismo das relações coletivas, é comum constatar, no decorrer da instrução de uma ação civil pública ambiental, que os danos causados ao meio ambiente são mais graves e abrangentes do que os descritos na inicial, quando da descrição dos fatos constitutivos do pedido. Para isso, o pedido pode ser genérico (reparação integral dos danos que vierem a ser constatados). De qualquer forma, estaria havendo uma alteração da causa de pedir remota. Em situações como essa, caso já tivesse ocorrido o saneamento do feito, não seria permitido alterar-se a causa de pedir, dando ensejo, eventualmente, à

${ }^{462}$ CHIOVENDA, Giuseppe. Instituições..., op. cit., v. I, p. 364.

${ }^{463}$ GRINOVER, Ada Pellegrini. Direito Processual Coletivo. In Tutela Coletiva..., op. cit., p. 307.

${ }^{464}$ LEONEL, Ricardo de Barros. Causa de pedir e pedido: o direito superveniente. São Paulo: Método, 2006, p. 292 (g.n.). 
propositura de nova ação. A opção pelo sistema rígido, tradicional, acarretaria a propositura de novas demandas coletivas sempre que novos fatos fossem descobertos no decorrer do processo. Por outro lado, flexibilizar a estabilização da demanda abriria oportunidade para que, em um único processo e com uma única decisão, fosse resolvida, definitivamente, a crise de direito material.

Para o réu, a flexibilização também pode ser interessante, pois, além de mais econômica, traz a segurança de que não haverá outra(s) ação(ões) rediscutindo o mesmo thema decidendum - desde que atrele a isso o reconhecimento da litispendência também de forma mais flexivel, como proposto no presente trabalho.

Ao tratar de ações coletivas, WATANABE reconhece que "é na transposição do conflito de interesses do plano extraprocessual para o processual e na formulação do pedido de provimento jurisdicional que são cometidos vários equívocos"465.

Por sua vez, GABBAY questiona:

Se o legitimado ativo, ao formular o pedido, é o responsável pela livre escolha do interesse defendido (perspectiva individual ou coletiva individual homogêneo, coletivo ou difuso) ou se, em alguns casos, deverse-ia considerar a incindibilidade do objeto, de forma que não seria possivel segregar e fragmentar a defesa judicial do conflito, dada a indivisibilidade e interdependência de suas esferas ${ }^{466}$.

Como bem sentido por GIDI, “a regra tradicional, que limita rigidamente o objeto do processo ... [é] altamente perigosa, se for transferida para o processo coletivo, no qual o autor não é titular do direito levado a juízo" ${ }^{\$ 67}$. Isso porque, na jurisdição coletiva, mais do que no processo civil individual, existe uma inafastável necessidade de tutelar a controvérsia coletiva de forma completa e adequada.

\footnotetext{
465 WATANABE, Kazuo. Comentários ao artigo 81, CDC. Código brasileiro de defesa do consumidor: comentado pelos autores do anteprojeto. Rio de Janeiro: Forense Universitária, 2004, p. 811.

${ }^{466}$ GABBAY, Daniela. Processo coletivo..., op. cit., p. 58.

${ }^{467}$ GIDI, Antonio. Rumo..., op. cit., p. 47 (g.n.).
} 
Por fim, uma última remissão ao ANTEPRojeto DE Código BRASILEIRO DE Processos Coletivos da USP e à PROPOSta do Ministério da JustiÇA/SECRETARia de REFORMA DO JUDICIÁRIO há de ser feita, pois ambos contemplam a possibilidade de alteração do objeto litigioso do processo, como se vê nos artigos abaixo transcritos respectivamente:

Art. $4^{\circ}$. Parágrafo único. A requerimento da parte interessada, até a prolação da sentença, o juiz permitirá a alteração do pedido ou da causa de pedir, desde que seja realizada de boa-fé, não represente prejuízo injustificado para a parte contrária e o contraditório seja preservado, mediante possibilidade de nova manifestação de quem figure no pólo passivo da demanda, no prazo de $10(\mathrm{dez})$ dias, observado o parágrafo $3^{\circ}$ do artigo 10.

Art. 18. Nas ações coletivas, a requerimento do autor, em qualquer grau de jurisdição, o juiz ou tribunal poderá permitir a alteração do pedido ou da causa de pedir, desde que realizada de boa-fé e não importe prejuízo injustificado para a parte contrária, devendo ser preservado o contraditório, mediante a possibilidade de manifestação específica do réu, no prazo mínimo de quinze dias, facultada prova complementar.

As inovações trazidas pelas propostas, quanto às regras de estabilização de demandas, são consentâneas com a complexidade dos processos coletivos e, naturalmente, está sujeita a alguns requisitos, a saber: requerimento da parte interessada, boa-fé, inexistência de prejuízo injustificado para o réu, e observância do contraditório e da ampla defesa, o que pode representar, inclusive, a produção de novas provas.

Se, por um lado, essa solução pode trazer maior delonga ao processo, por outro, é certo que a prolação de uma só decisão que resolva toda a crise de direito material tende a ser mais rápida do que a propositura de novas ações (tantas quantas forem os fatos supervenientes), as quais darão início, de tempos em tempos, à rediscussão da mesma 
controvérsia material, acarretando demora ainda maior e maiores custos quanto à solução definitiva e integral do conflito ${ }^{468}$.

\section{IV.1.3. A relação entre demandas coletivas no ANTEPROJETO DA USP e na PROPOSTA DO MINISTÉRIO DA JUSTIÇA ${ }^{469}$}

Como encerramento do presente trabalho, não podíamos deixar de analisar os dispositivos do Anteprojeto de Código Brasileiro de Processos Coletivos da USP e da proposta de Alteração DA Lei dA AÇÃo Civil PÚblica do Ministério dA JUSTIÇA/SECRETARIA DE REFORMA DO JUDICIÁRIO que tratam, especificamente, da relação entre demandas coletivas.

De início, cumpre analisar a proposta contida no AnteProjeto DE Código Brasileiro de Processos Coletivos da USP. Dispõe seu artigo $5^{\circ}$ que:

Art. $5^{\circ}$. Relação entre demandas coletivas - Observado o disposto no artigo 20 deste Código, as demandas coletivas de qualquer espécie poderão ser reunidas, de ofício ou a requerimento das partes, ficando prevento o juízo perante o qual a demanda foi distribuída em primeiro lugar, quando houver:

I - conexão, pela identidade de pedido ou causa de pedir, conquanto diferentes os legitimados ativos, e para os fins da ação prevista no Capítulo III, os legitimados passivos;

II - continência, pela identidade de partes e causa de pedir, observado o disposto no inciso anterior, sendo o pedido de uma das ações mais abrangente do que o das demais.

$\S 1^{\circ}$. Na análise da identidade do pedido e da causa de pedir, será considerada a identidade do bem jurídico a ser protegido.

\footnotetext{
${ }^{468}$ Cf. LEONEL, Ricardo de Barros. Causa de pedir e pedido: o direito superveniente. São Paulo: Método, 2006, p. 293/294.

${ }^{469}$ Conforme já salientado, além das duas propostas ora analisadas, existem outras duas propostas sendo discutidas no cenário nacional, quais sejam: o ANTEPROJETO DE ANTONIO GIDI e o ANTEPROJETO DAS UNIVERSIDADES DO ESTADO DO RIO DE JANEIRO (UERJ) E ESTÁCIO DE SÁ (UNESA).
} 
$\S 2^{\circ}$. Na hipótese de conexidade entre ações coletivas referidas ao mesmo bem jurídico, o juiz prevento deverá obrigatoriamente determinar a reunião de processos para julgamento conjunto.

$\S 3^{\circ}$. Aplicam-se à litispendência as regras dos incisos I e II deste artigo, quanto à identidade de legitimados ativos ou passivos, e a regra de seu parágrafo $1^{\mathrm{o}}$, quanto à identidade do pedido e da causa de pedir ${ }^{470}$ (g.n.).

A proposta do ANTEPROJETO está em consonância com a posição majoritária da doutrina e da jurisprudência. Primeiro, porque o requisito da identidade física da parte foi expressamente afastado, tornando de lege lata o que, hoje, já é pacificamente aceito de lege ferenda. Segundo, porque foi dada maior ênfase aos elementos objetivos da demanda, os quais serão analisados considerando a identidade do bem jurídico a ser protegido. Tratase de uma clara (e esperada!) flexibilização do conceito de identidade de ações.

Embora essa flexibilização facilite, em tese, o reconhecimento da litispendência, não foi essa a opção adotada pelo ANTEPROJETO: a solução prática escolhida foi a reunião das demandas coletivas para julgamento conjunto, seguindo-se a sistemática (mais conservadora) da conexão. Com vistas a minimizar eventuais "efeitos colaterais" dessa opção legislativa, previu-se que o juiz deverá obrigatoriamente determinar a reunião de processos para julgamento conjunto, o que tende a evitar a prolação de comandos contraditórios.

Em que pesem os avanços da proposta em relação ao sistema atual, entende-se que o ANTEPROJETO pode ir além, adotando a sistemática da litispendência, especialmente porque o mais difícil foi feito, ou seja, a dispensa de uma exata identidade entre os elementos das ações comparadas.

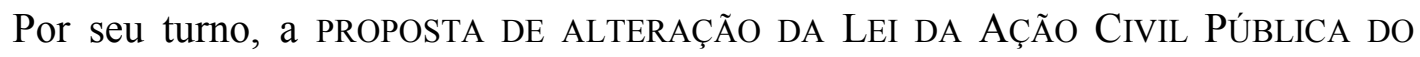
MinistÉRIO DA JustiÇA/SECRETARIA DE REFORMA DO JUdiciÁRIO tratou a questão da seguinte forma:

\footnotetext{
${ }^{470}$ Redação extraída do ANTEPROJETO apresentado ao Ministério da Justiça por Ada Pellegrini GRINOVER, após reuniões com Ministério Público e órgãos do Governo Federal, em dezembro de 2005 / Última versão.
} 
Art. $7^{\circ}$. A distribuição de uma ação coletiva induzirá litispendência para as demais ações coletivas que tenham o mesmo pedido, causa de pedir e interessados e prevenirá a competência do juízo para todas as demais ações coletivas posteriormente intentadas que possuam a mesma causa de pedir ou o mesmo objeto, ainda que diferentes os legitimados coletivos, quando houver:

I - conexão, pela identidade de pedido ou causa de pedir ou da defesa, conquanto diferentes os legitimados;

II - conexão probatória;

III - continência, pela identidade de interessados e causa de pedir, quando o pedido de uma das ações for mais abrangente do que o das demais.

$\S 1^{\circ}$. Na análise da identidade da causa de pedir e do objeto, será preponderantemente considerado o bem jurídico a ser protegido.

$\S 2^{\circ}$. Na hipótese de conexão ou continência entre ações coletivas que digam respeito ao mesmo bem jurídico, o juízo prevento, até o início da instrução, deverá determinar a reunião de processos para julgamento conjunto. Iniciada a instrução a reunião dos processos somente poderá ser determinada se não houver prejuízo para a duração razoável do processo. (g.n.)

Tal qual o ANTEPROJETO DA USP, a proposta do Ministério DA JustiÇA/SECRETARIA DE REFORMA DO JUDICIÁRIO dispensa a identidade física da parte, referindo-se aos 'interessados' (rectius: os substituídos). Apesar disso, o caput do artigo $7^{\circ}$ continua a exigir a 'tríplice identidade' para o reconhecimento da litispendência, com a ressalva de que, na análise da identidade da causa de pedir e do pedido, será considerado o bem jurídico tutelado, flexibilizando-se o conceito de identidade de ações.

A PROPOSTA DO Ministério DA JustiÇA/SECRETARIA DE REFORMA DO JUDICIÁRIO também privilegia a sistemática da reunião das demandas para julgamento conjunto, sendo esta obrigatória somente até o início da instrução. As críticas tecidas ao ANTEPROJETO DA USP valem, da mesma forma, à PROPOSTA DO MINISTÉRIO DA JUSTIÇA - com a agravante de, aqui, os riscos de decisões conflitantes serem ainda maiores. 


\section{CONCLUSÃO}

Revisitando os temas abordados ao longo do presente trabalho, podem-se extrair algumas conclusões acerca do tema Relação entre Demandas Coletivas, com ênfase no dano ambiental. O primeiro passo para tanto é retomar a pergunta central que direcionou nossa pesquisa e que pode ser assim sintetizada: é cabível a transposição, sic et simpliciter, dos institutos processuais clássicos voltados à relação entre demandas individuais (conexão, continência, litispendência e coisa julgada) para o plano da jurisdição coletiva? Em caso negativo, a pergunta que deve ser feita na seqüência é: que inovações precisam ser feitas nesses institutos, em sede de tutela coletiva, para que eles atinjam a finalidade de impedir que uma situação de fato idêntica, submetida a uma mesma disciplina jurídica, receba tratamentos diferenciados?

Em que pese o fato de o presente trabalho ter buscado uma resposta para tais perguntas, não se pode perder de vista que a resposta certa não importa nada: o essencial é que as perguntas estejam certas (Mario Quintana). De qualquer forma, de tudo o que foi analisado, destacam-se as seguintes conclusões, que, juntas, constroem uma linha de raciocínio com o intuito de oferecer uma resposta aos citados questionamentos - ainda que de lege ferenda.

1. Na difícil tarefa de identificação de demandas, doutrina e jurisprudência costumam lançar mão da teoria da tríplice identidade (partes, causa de pedir e pedido), com base na teoria da substanciação. Todavia, perante várias situações concretas, esta teoria mostra-se insuficiente para solucionar o confronto de duas ou mais ações. Assim, a despeito de sua adoção expressa pelo $\mathrm{CPC}$, não se pode perder de vista que os tria eadem não constituem um critério absoluto, mas, sim, uma 'boa hipótese de trabalho', razão pela qual deve ser admitida a aplicação subsidiária da teoria da identidade da relação jurídica. Ambas as teorias não se excluem, mas, ao contrário, complementam-se, tendo em vista que se destinam a uma única finalidade: dizer quando o conteúdo de um processo é idêntico ao de outro, para vedar-se a reprodução simultânea ou sucessiva (litispendência ou coisa 
julgada) de duas demandas, porque isso atenta contra o bom funcionamento da justiça;

2. Na operação de identificação das ações, mais do que o elemento subjetivo, deve-se identificar o objeto litigioso do processo, também entendido como o pedido devidamente iluminado pela causa de pedir (sendo que esta última deverá conter os fatos constitutivos do direito e o fundamento jurídico do pedido - aproximando-se as teorias da substanciação e da individuação);

3. As dificuldades percebidas no plano da jurisdição singular tornam-se ainda mais complexas no plano da jurisdição coletiva, pois aqui os perigos redobram. Isso porque, segundo as regras do microssistema processual coletivo (LAP, LACP e CDC), as demandas coletivas apresentam as seguintes peculiaridades, dentre outras: (i) a legitimação para agir é extraordinária, sob a forma concorrente-disjuntiva, facultando-se a vários co-legitimados a propositura de ação, em nome próprio, no interesse da coletividade; (ii) a coisa julgada é erga omnes ou ultra partes, ampliando-se os limites subjetivos do julgado; (iii) o objeto é indivisivel ${ }^{471}$, o que confere aos interesses metaindividuais um tratamento unitário, de forma que a satisfação de um interessado implica necessariamente a satisfação de todos;

4. Em função dessas características, a justaposição entre ações de tipo coletivo traz complicações seríssimas, por conta da projeção erga omnes ou ultra partes da coisa julgada, caso em que a virtual prolação de comandos de conteúdo diverso engendrará contradição não só no plano lógico, mas desbordará para o plano prático; afinal, como poderiam, autores e réus, atender a dois julgados, quando um acolhesse o pedido de declaração de nulidade do ato de nomeação e o outro considerasse válido o mesmo ato?;

5. As peculiaridades dos interesses metaindividuais reclamam instrumentos adequados e, por vezes, mais 'maleáveis' que os institutos processuais clássicos;

6. No que tange à relação entre demandas coletivas, essa flexibilização iniciase pela aplicação subsidiária da teoria da identidade da relação jurídica em adição à teoria dos tria eadem, de tal forma que o foco recaia sobre o núcleo essencial / o 'thema decidendum' / o bem jurídico coletivo / o resultado

${ }^{471}$ A esse respeito, inclusive, vale lembrar que nenhum outro interesse tem difusão maior do que o meio ambiente, que pertence a todos em geral e a ninguém em particular. 
prático visado pelos processos, o que se revela pela causa de pedir remota $\mathrm{e}$ pelo pedido mediato;

7. Em adição a essa conjugação dos elementos objetivos, o elemento parte também é 'relativizado' para dar maior relevância à sua qualidade jurídica e não à sua identidade física, tendo em vista que os legitimados ativos são substitutos processuais da coletividade;

8. Assim, não é necessário que a segunda demanda seja rigorosamente idêntica à primeira para que ela seja inadmissível em razão da litispendência. Dos seis elementos da ação, basta que apenas dois sejam comuns: a causa de pedir remota e o pedido mediato. A conjugação desses dois elementos permite a identificação do núcleo essencial da demanda, ou seja, do bem jurídico coletivo tutelado em ambas as ações - o que, em última análise, não escapa da análise (subsidiária) da própria relação jurídica substancial;

9. Nessa análise, deve-se atentar para as circunstâncias materiais (fatos, no sentido de ocorrências da vida) e para o resultado prático visado pelos processos (bem jurídico tutelado);

10. Por meio dessa visão inovadora, atinge-se o objetivo maior de impedir que uma situação de fato idêntica, submetida a uma mesma disciplina jurídica, receba tratamentos diferenciados, ou seja, com decisões judiciais divergentes, em alguns casos opostas;

11. Daí se dizer que nem sempre é possível tutelar direitos coletivos por intermédio das regras do direito processual civil clássico, as quais foram concebidas por uma filosofia liberal-individualista arraigada, não mais adequada à sociedade e aos conflitos de massa;

12. Fácil notar que essa flexibilização favorece a configuração da litispendência, dado o abrandamento dos seus requisitos ("identidade de seis elementos $x$ semelhança de dois elementos"). No entanto, a solução a ser dada para o conflito depende de uma opção legislativa: reunir as ações para julgamento conjunto (= conexão) ou extinguir as demandas subseqüentes (= litispendência)?;

13. A reunião de processos coletivos é tida por muitos como a melhor solução, por quatro motivos fundamentais: (i) porque o segundo processo pode estar mais adiantado que o primeiro; (ii) porque o autor do segundo processo 
pode ser mais adequado do que o do primeiro; (iii) porque os processos podem ter objetos diferentes; e (iv) porque, com a reunião, todos os colegitimados poderão participar do processo;

14. Diante disso, a maioria da doutrina sustenta que ainda que haja coincidência entre o objeto de duas ações coletivas, não há lugar para a invocação da litispendência, devendo haver a reunião dos processos, com fundamento na conexão, para tramitação e decisão conjunta;

15. De outro lado, há quem defenda que, quando dois ou mais legitimados ativos intentarem ações coletivas com base nos mesmos eventos ocorridos no mundo dos fatos e visando ao mesmo resultado prático, estará caracterizada verdadeira litispendência, devendo as ações subseqüentes ser extintas. Isso porque, em rigor, dada a indivisibilidade do objeto, não sobeja espaço processual para uma segunda ação coletiva e bem assim para as subseqüentes, porque a primeira já é suficiente para cuidar do thema decidendum e já torna litigioso o objeto, além do que a tutela ofertada na jurisdição coletiva é de cunho molecular, cujo perímetro abrange as possíveis demandas-átomo, tudo em ordem a evitar a pulverização do conflito coletivo. Por esse viés, faltaria interesse de agir às ações coletivas ulteriores com o mesmo objeto da primeira, justificando-se a extinção delas sem julgamento de mérito;

16. Ademais, não se pode perder de vista que a reunião dos processos é entendida como uma faculdade do juiz, de tal forma que a opção mais segura pode ser a extinção da segunda ação, para evitar que uma mesma situação de fato receba tratamentos diferenciados;

17. Assim, no que tange à litispendência entre ações coletivas, deve-se dispensar a exigência de uma exata identidade entre os elementos (partes, pedido e causa - os 'tria eadem') das ações comparadas;

18. Essa solução atende à finalidade de molecularização, que é a própria razão de ser das demandas coletivas, potencializando a resposta judiciária, por modo que um só comando possa resolver o conflito metaindividual em modo unitário e isonômico; e

19. Extintas as demandas subseqüentes, seria autorizado aos autores dos processos extintos intervir no primeiro processo e trabalhar colaborativamente em um único processo. Para que essa intervenção seja 
eficaz (para que os legitimados possam efetivamente contribuir para a melhoria da primeira ação), é necessário 'abrandar' as regras de estabilização da demanda, permitindo a alteração do pedido e da causa de pedir, desde que realizada de boa-fé e que seja garantido o contraditório e a ampla defesa. Outrossim, ao juiz também poderá interpretar extensivamente os elementos objetivos, devido à indisponibilidade dos bens objeto de tutela coletiva.

A bem ver, portanto, é legítima a conclusão no sentido de que não é cabível a transposição, sic et simpliciter, dos institutos processuais clássicos voltados à relação entre demandas individuais (conexão, continência, litispendência e coisa julgada) para o plano da jurisdição coletiva, sendo necessário flexibilizar/modernizar estas e outras figuras, a começar pelo próprio conceito de identidade de ações, com vistas a impedir que a mesma situação de fato receba tratamentos diferenciados em duas ou mais demandas. Tudo em prol da efetividade do processo coletivo e dos princípios da economia processual, da isonomia e da certeza das relações jurídicas.

A esse respeito, as propostas de codificação do direito processual coletivo analisadas neste trabalho afastam expressamente o requisito da identidade física da parte, tornando de lege lata o que, hoje, já é pacificamente aceito de lege ferenda; além disso, dão maior ênfase aos elementos objetivos da demanda, os quais devem ser analisados levando-se em conta a identidade do bem jurídico a ser protegido. Trata-se de uma clara flexibilização do conceito de identidade de ações. Embora essa modernização facilite, em tese, o reconhecimento da litispendência, não foi essa a opção adotada pelo ANTEPROJETO DA USP: a solução prática escolhida foi a reunião das demandas coletivas para julgamento conjunto, seguindo-se a sistemática (mais conservadora) da conexão. Com vistas a minimizar eventuais "efeitos colaterais" dessa opção legislativa, previu-se que o juiz deverá obrigatoriamente determinar a reunião de processos para julgamento conjunto, o que tende a evitar a prolação de comandos contraditórios. 
Por fim, não se ignora o fato de que as propostas constantes do presente trabalho (em sua maioria, de lege ferenda) dependem de uma compreensão arrojada por parte do intérprete, o que indica que a matéria ainda demanda estudo e desenvolvimento. Assim, longe de representarem proposições de pretensa certeza, as propostas aqui abordadas configuram apenas uma tentativa de equacionamento dos problemas decorrentes da concomitância/concorrência de ações coletivas, dadas a relevância do tema e as dificuldades enfrentadas no dia-a-dia dos operadores do direito. 


\section{REFERÊNCIAS BIBLIOGRÁFICAS}

ALMEIDA, Gregório Assagra de. Direito Processual Coletivo Brasileiro - Um novo ramo do Direito Processual. São Paulo: Saraiva, 2004.

. Codificação do direito processual coletivo brasileiro. Belo Horizonte: Del Rey, 2007.

. Direito material coletivo - superação da summa divisio direito público e direito privado por uma nova summa divisio constitucionalizada. Belo Horizonte: Del Rey, 2008.

AMARAL SANTOS, Moacyr. Primeiras linhas de direito processual civil. São Paulo: Saraiva, 1997, v. I.

ARAÚJO FILHO, Luiz Paulo da Silva. Comentários ao Código de Defesa do Consumidor. São Paulo: Saraiva, 2002.

ARRUDA ALVIM. Ensaio sobre a litispendência no Direito Processual Civil. São Paulo: Revista dos Tribunais, 1970, v. I e II.

. Direito Processual Civil - Teoria Geral do Processo de Conhecimento.

São Paulo: Revista dos Tribunais, 1972.

. Código de Defesa do Consumidor Comentado. São Paulo: Revista dos Tribunais, 1995.

. Manual de Direito Processual Civil. São Paulo: Revista dos Tribunais, 1996, v. I.

- Notas sobre a coisa julgada coletiva. Revista da Associação dos Magistrados Brasileiros - Cidadania e Justiça 9/101. 
ARRUDA ALVIM, Eduardo. Coisa julgada a litispendência no Anteprojeto de Código Brasileiro de Processos Coletivos. In Direito Processual Coletivo e o Anteprojeto de Código Brasileiro de Processos Coletivos. GRINOVER, Ada Pellegrini, MENDES, Aluisio Gonçalves de Castro e WATANABE, Kazuo (Coords.). São Paulo: Revista dos Tribunais, 2007, p. 174/193.

AZEVEDO, Antonio Junqueira de. Conceito, identificação e conexão de causas no direito processual civil. São Paulo: Escolas Profissionais Salesianas, 1967.

BARBOSA MOREIRA, José Carlos. Apontamentos para um estudo sistemático da legitimação extraordinária. In Direito Processual Civil (ensaios e pareceres). Rio de Janeiro: Borsoi, 1971.

- A ação popular no direito brasileiro como instrumento de tutela jurisdicional dos chamados 'interesses difusos'. In Temas de direito processual, primeira série. São Paulo: Saraiva, 1977.

. A conexão de causas como pressuposto da reconvenção. São Paulo: Saraiva, 1979.

. Os temas fundamentais do direito brasileiro nos anos 80. Revista Brasileira de Direito Processual, v. 47, p. 69/75.

. Ações coletivas na Constituição Federal de 1988. Revista de Processo. n. 62. São Paulo: REVISTA DOS TRIBUNAIS, jan./mar. 1991, p. 187/200.

. O novo processo civil brasileiro: exposição sistemática do procedimento.

Rio de Janeiro: Forense, 1999.

. A expressão 'competência funcional' no art. $2^{\circ}$ da Lei da Ação Civil Pública. Revista Forense, v. 380, ano 101. Rio de Janeiro: Forense, p. 179/187, jul.-ago. 2005. 
BEDAQUE, José Roberto dos Santos. Direito e processo: influência do direito material sobre o processo. São Paulo: Malheiros Editores, 1995.

. Direito e processo: influência do direito material sobre o processo. São Paulo: Malheiros, 1997.

. Efetividade do Processo e Técnica Processual. São Paulo: Malheiros, 2006.

BOEIRA, Alex Perozzo. A litispendência na ação popular. Revista Síntese. São Paulo: Síntese, 2001.

CALAMANDREI, Piero. Instituzioni di diritto processuale civile secondo Il nuovo codice. Padova: Cedam, 1943.

CAMBI, Eduardo Augusto Salomão. Jurisprudência lotérica. Revista dos Tribunais. São Paulo: Revista dos Tribunais, v. 786, p. 108/128, 2001.

CANOVA, Augusto Cerino. La domanda giudiziale ed il suo contenuto. Comentario del Codice di Procedura Civile. Torino: Uted, 1980.

CAPPELLETTI, Mauro. Formações sociais e interesses coletivos diante da Justiça Civil, Formações sociais e interesses coletivos diante da Justiça Civil. Revista de Processo n. 5, São Paulo: Revista dos Tribunais, 1977.

e GARTH, Bryant. Acesso à justiça. Porto Alegre: Fabris, 1998.

CAPPELLETTI, Mauro. Vindicating the public interest through the courts. The judicial process in comparative perspective. Oxford: Clarendon Press, 1989.

CARMONA, Carlos Alberto. Novidades sobre a execução civil: observações sobre a Lei 11.232/2005. In A Nova Execução de Títulos Judiciais: comentários à Lei 11.232/05. RENAULT, Sérgio e BOTTINI, Pierpaolo (Orgs.). São Paulo: Saraiva, 2006. 
CARVALHO, Délton Winter de. A proteção jurisdicional do meio ambiente: uma relação jurídica comunitária. Revista de Direito Ambiental. São Paulo: Revista dos Tribunais, n. 24, 2001.

CARVALHO, Milton Paulo de. Pedido novo e adiantamento de pedido. O art. 294 do Código de Processo Civil na sua nova redação. In Processo Civil - Evolução - Vinte anos de vigência. CRUZ E TUCCI, José Rogério (Coord.). São Paulo: Saraiva, 1995.

CHIOVENDA, Giuseppe. Principii di diritto processualie civile. Nápoles: Jovene, 1928.

Instituições de Direito Processual Civil. MENEGALE, J. Guimarães (Trad.). LIEBMAN, Enrico Tullio (Notas). São Paulo: Saraiva, v. I, 1965.

. Instituições de Direito Processual Civil. MENEGALE, J. Guimarães (Trad.). LIEBMAN, Enrico Tullio (Notas). São Paulo: Saraiva, v.II, 1943.

CINTRA, Antonio Carlos de Araujo, GRINOVER, Ada Pellegrini e DINAMARCO, Cândido Rangel. Teoria Geral do Processo. São Paulo: Malheiros, 2005.

COGLIOLO, Pietro. Trattato teorico e pratico della eccezione di cosa giudicata, secondo il diritto romano e il codice civile italiano, con accenni al diritto intermedio, dell'avv. Fratelli Bocca, 1883.

CRUZ E TUCCI, José Rogério, Class action e mandado de segurança coletivo: diversificações conceptuais. São Paulo, Saraiva, 1990.

e TUCCI, Rogério Lauria. Devido processo legal e tutela jurisdicional. São Paulo: Revista dos Tribunais, 1993.

. Código do Consumidor e Processo civil - Aspectos polêmicos. Revista dos Tribunais, n. 671, p. 35/39, São Paulo: REVISTA DOS TRIBUNAIS, set. 1991.

. A causa petendi no processo civil. São Paulo: Revista dos Tribunais, 2001. 
D’ONOFRIO, Paolo. Identificazione delle azioni in rapporto allá teoria della litispendenza e della cosa giudicata. Benevento: Coop. Tipogr., 1924.

DIAS, Jefferson Aparecido. A efetividade das decisões proferidas em ações civis públicas. In Ação Civil Pública - 20 anos da Lei 7.347/85. ROCHA, João Carlos de Carvalho, HENRIQUES Fo, Tarcísio Humberto Parreiras, CAZETTA, Ubiratan (Coords.). Belo Horizonte: Del Rey, 2005, p. 81/101.

DIÉGUEZ, Francisco Málaga. La litispendência. Barcelona: Bosh, 1999.

DINAMARCO, Cândido Rangel. Execução Civil. São Paulo: Malheiros, 1994. . Litisconsórcio. São Paulo: Malheiros, 1994.

. A instrumentalidade do processo. São Paulo: Malheiros, 1998. . Instituições de Direito Processual Civil. São Paulo: Malheiros, 2005 v. I, II e III.

DINAMARCO, Pedro Silva. Ação civil Pública. São Paulo: Saraiva, 2001.

. Competência, conexão e prevenção nas ações coletivas. In Ação Civil Pública após 20 anos: efetividade e desafios. MILARÉ, Édis (Coord.). São Paulo: Revista dos Tribunais, 2005, p. 505/518.

ERICKSON, John. Nosso planeta está morrendo. SANTOS, José Carlos Barbosa dos (Trad.). São Paulo: Makron/McGraw-Hill, 1992.

FABRÍCIO, Adroaldo Furtado. As novas necessidades do processo civil e os poderes do juiz. In O Judiciário e a Constituição. TEIXEIRA, Sálvio de Figueiredo (Org.). São Paulo: Saraiva, 1994.

FAZZALARI, Elio. Note in tema di diritto e processo. Milano: Giuffrè, 1957. 
FERRAZ, Sérgio. Responsabilidade civil por dano ecológico. Revista de Direito Público, São Paulo: 1979, v. 49-50.

FINK, Daniel Roberto. Alternativa à ação civil pública ambiental. In Ação Civil Pública - Lei 7.347/1985 - 15 anos. MILARÉ, Édis (Coord.). São Paulo: Revista dos Tribunais, 2001.

FISS, Owen. Teoria Política das ações coletivas. In Um novo processo civil: estudos norte-americanos sobre jurisdição, constituição e sociedade. SALLES, Carlos Alberto de (Coord. Trad.). São Paulo: Revista dos Tribunais, 2004.

FRANCHI, Giuseppe. La litispendenza. Padova: CEDAM, 1963.

FREDERICO MARQUES, José. Instituições de direito processual civil. Rio de Janeiro: Forense, 1962.

. As ações populares no direito brasileiro. Revista dos Tribunais, 266/5-13.

GABBAY, Daniela. Processo coletivo e elementos objetivos da demanda. Dissertação (Mestrado). 23.10.2007. Orientador: Prof. Dr. Carlos Alberto de Salles. São Paulo, 2007. Faculdade de Direito, Universidade de São Paulo.

GAVRONSKI, Alexandre Amaral. Propostas para incrementar a efetividade dos instrumentos previstos na Lei n. 7.347/85 e ampliar o acesso à justiça nos direitos coletivos. In Ação Civil Pública - 20 anos da Lei 7.347/85. ROCHA, João Carlos de Carvalho, HENRIQUES Fo, Tarcísio Humberto Parreiras, CAZETTA, Ubiratan (Coords.). Belo Horizonte: Del Rey, 2005.

GIDI, Antonio. Coisa julgada e litispendência em ações coletivas. São Paulo: Saraiva, 1995.

. A class action como instrumento de tutela coletiva dos direitos. São Paulo: Revista dos Tribunais, 2007. 
. Rumo a um Código de Processo Civil Coletivo: a codificação das ações coletivas no Brasil. Rio de Janeiro: Forense Universitária, 2008.

GOMES JR, Luiz Manoel. Curso de Direito Processual Civil Coletivo. São Paulo: SRS, 2008.

GRINOVER, Ada Pellegrini. Eficácia e autoridade da sentença penal. São Paulo: Revista dos Tribunais, 1978.

. Da coisa julgada no Código de Defesa do Consumidor. Revista da Associação dos Advogados de São Paulo, n. 33, dez. 1990, p. 05/15.

. Ação coletiva fortalece proteção. O Estado de S. Paulo, de 14.12.1991, Caderno Justiça.

. Uma nova modalidade de legitimação à ação popular. Possibilidade de conexão, continência e litispendência. In Ação Civil Pública - reminiscências e reflexões após 10 anos de aplicação. MILARÉ, Édis (Coord.). São Paulo: Revista dos Tribunais, 1995, p. 23/27.

. A coisa julgada perante a Constituição, a Lei da Ação Civil Pública, o Estatuto da Criança e do Adolescente e o Código de Defesa do Consumidor. O processo em evolução. Rio de Janeiro: Forense Universitária, 1996.

Ação civil pública. Palestra proferida no Seminário Tutela dos Interesses Difusos e Coletivos - Inquérito Civil e Ação Civil Pública - Aspectos Polêmicos, realizado em 20.11.1996, na Escola Paulista do Ministério Público. Boletim Informativo ESMP, n. 3, p. 1, 1996.

- A ação civil pública no STJ. A marcha do processo. Rio de Janeiro: Forense Universitária, 2000. 
et alii. As nulidades do processo penal. São Paulo: Revista dos Tribunais, 2000.

. Defesa do meio ambiente em juízo como conquista da cidadania. Revista de Direitos Difusos, v. 2, 2000, p. 121/128.

et alii. Código Brasileiro de Defesa do Consumidor comentado pelos autores do Anteprojeto. Rio de Janeiro: Forense Universitária, 2004.

. Rumo a um Código Brasileiro de Processos Coletivos - Exposição de Motivos. In Tutela Coletiva: 20 anos da Ação Civil Pública e Fundo de Defesa de Direitos Difusos, 15 anos do Código de Defesa do Consumidor. LUCON, Paulo Henrique dos Santos (Coord.). São Paulo: Atlas, 2006, p. 1/6.

. Direito Processual Coletivo. In Tutela Coletiva: 20 anos da Ação Civil Pública e Fundo de Defesa de Direitos Difusos, 15 anos do Código de Defesa do Consumidor. LUCON, Paulo Henrique dos Santos (Coord.). São Paulo: Atlas, 2006, p. $302 / 308$.

, MENDES, Aluisio Gonçalves de Castro e WATANABE, Kazuo (Coords.). Direito Processual Coletivo e o Anteprojeto de Código Brasileiro de Processos Coletivos. São Paulo: Revista dos Tribunais, 2007.

. Fundamentos da Justiça Conciliativa. Revista dos Tribunais. Cadernos de Direito Constitucional e Ciência Política, v. 14, p. 16-21, 2007.

KLONOFF, Class action and other multi-party litigation. Saint Paul: Thomson/West, 2004.

LACERDA, Galeno. Ação Civil Pública. Revista do MP do Rio Grande do Sul, n. 19, 1986 (conferência proferida em 17.10.1985).

LEAL, Márcio Flávio Mafra. Ações coletivas: história, teoria e prática. Porto Alegre: Fabris, 1998. 
LENZA, Pedro. Teoria Geral da Ação Civil Pública. São Paulo: Revista dos Tribunais, 2005

LEONEL, Ricardo de Barros. Manual do processo coletivo. São Paulo: Revista dos Tribunais, 2002.

. A causa petendi nas ações coletivas. In Causa de pedir e pedido no processo civil. CRUZ E TUCCI, José Rogério e BEDAQUE, José Roberto dos Santos (Coords.). São Paulo: Revista dos Tribunais, 2002.

. Causa de pedir e pedido: o direito superveniente. São Paulo: Método, 2006.

. Causa de pedir e pedido nos processos coletivos: uma nova equação para a estabilização da demanda. In Direito Processual Coletivo e o Anteprojeto de Código Brasileiro de Processos Coletivos. GRINOVER, Ada Pellegrini, MENDES, Aluisio Gonçalves de Castro e WATANABE, Kazuo (Coords.). São Paulo: Revista dos Tribunais, 2007, p. 144/155.

LIEBMAN, Enrico Tullio. Limites objetivos da coisa julgada. Estudos sobre o Processo Civil brasileiro (com notas de GRINOVER, Ada Pellegrini). São Paulo: Bushatsky, 1976.

. Manual de Direito Processual Civil. DINAMARCO, Cândido Rangel (Trad.). Rio de Janeiro: Forense, 1984.

- Eficácia e Autoridade da Sentença e Outros Escritos Sobre a Coisa Julgada (atualizado por GRINOVER, Ada Pellegrini). Rio de Janeiro: Forense, 2007.

LIMA, Maria Rosynete Oliveira. Devido processo legal. Porto Alegre: Fabris, 1999. 
LIPOVETSKY, Gilles. A felicidade paradoxal: ensaio sobre a sociedade de hiperconsumo. MACHADO, Maria Lucia(Trad.). São Paulo: Companhia das Letras, 2007.

LUCON, Paulo Henrique dos Santos (Coord.). Tutela Coletiva: 20 anos da Ação Civil Pública e Fundo de Defesa de Direitos Difusos, 15 anos do Código de Defesa do Consumidor. São Paulo: Atlas, 2006.

LUCON, Paulo Henrique dos Santos, GABBAY, Daniela Monteiro, ALVES, Rafael Francisco e ANDRADE, Tathyana Chaves de. Interpretação do pedido e da causa de pedir nas demandas coletivas (conexão, continência e litispendência). In Tutela Coletiva: 20 anos da Ação Civil Pública e Fundo de Defesa de Direitos Difusos, 15 anos do Código de Defesa do Consumidor. Tutela Coletiva. LUCON, Paulo Henrique dos Santos (Coord.). São Paulo: Atlas, 2006, p. 184/199.

MACIEL JUNIOR, Vicente de Paula. Teoria das ações coletivas. As ações coletivas como ações temáticas. São Paulo: LTr, 2006.

MANCUSO, Rodolfo de Camargo. Comentários ao Código de Defesa do Consumidor. São Paulo: Saraiva, 1991.

. Uma análise comparativa entre os objetos e as legitimidades ativas das ações vocacionadas à tutela dos interesses metaindividuais: mandado de segurança coletivo, ação civil pública, ações do Código de Defesa do Consumidor e ação popular. Justitia, 54 (160), São Paulo, out./dez., p. 181/203, 1992.

- A concomitância de ações coletivas, entre si, e em face das ações individuais. Revista dos Tribunais, ano 89, v. 782, São Paulo, dez. 2000, p. 20/47.

. Manual do consumidor em juízo. São Paulo: Saraiva, 2001.

. Ação popular: proteção do erário, do patrimônio público, da moralidade administrativa e do meio ambiente. São Paulo: Revista dos Tribunais, 2003. 
. Interesses difusos - conceito e legitimação para agir. São Paulo: Revista dos Tribunais, 2004.

. Transposição das águas do Rio São Francisco: uma abordagem jurídica da controvérsia. In Ação Civil Pública após 20 anos: efetividade e desafios. MILARÉ, Édis (Coord.). São Paulo: Revista dos Tribunais, 2005, p. 519/558.

. Jurisdição Coletiva e Coisa Julgada - Teoria Geral das Ações Coletivas. São Paulo: Revista dos Tribunais, 2006.

. Ação Civil Pública: em defesa do meio ambiente, do patrimônio cultural e dos consumidores. São Paulo: Revista dos Tribunais, 2007.

. Divergência jurisprudencial e súmula vinculante. São Paulo: Revista dos Tribunais, 2007.

. A concomitância entre ações de natureza coletiva. In Direito Processual Coletivo e o Anteprojeto de Código Brasileiro de Processos Coletivos. GRINOVER, Ada Pellegrini, MENDES, Aluisio Gonçalves de Castro e WATANABE, Kazuo (Coords.). São Paulo: Revista dos Tribunais, 2007, p. 161/173.

MARINONI, Guilherme e ARENHART, Sérgio Cruz. Manual do processo de conhecimento. São Paulo: Revista dos Tribunais, 2003.

MATTOS, Luiz Norton Baptista de. A litispendência e a coisa julgada nas ações coletivas segundo o Código de Defesa do Consumidor e os anteprojetos do Código Brasileiro de Processos Coletivos. In Direito Processual Coletivo e o Anteprojeto de Código Brasileiro de Processos Coletivos. GRINOVER, Ada Pellegrini, MENDES, Aluisio Gonçalves de Castro e WATANABE, Kazuo (Coords.). São Paulo: Revista dos Tribunais, 2007, p. 194/215.

MAZZEI, Rodrigo e NOLASCO, Rita Dias (Coords.). Processo Civil Coletivo. São Paulo: Quartier Latin, 2005. 
MAZZILLI, Hugo Nigro. A defesa dos interesses difusos em juizo: meio ambiente, consumidor, patrimônio cultural, patrimônio público e outros interesses. São Paulo: Saraiva, 2005.

MAZZILLI, Hugo Nigro. Ação Civil Pública. Livro de Estudos Jurídicos. Rio de Janeiro: Instituto de Estudos Jurídicos, 6:95-106, 1992.

MENDES, Aluísio Gonçalves de Castro. Ações coletivas no direito comparado e nacional. São Paulo: Revista dos Tribunais, 2002.

. O Anteprojeto de Código Modelo de Processos Coletivos para os Países Ibero-Americanos e a legislação brasileira. Gênesis - Revista de Direito Processual Civil 31/11, jan.-mar. 2004.

. O Código Modelo de Processos Coletivos. In Tutela Coletiva: 20 anos da Ação Civil Pública e Fundo de Defesa de Direitos Difusos, 15 anos do Código de Defesa do Consumidor. Tutela Coletiva. LUCON, Paulo Henrique dos Santos (Coord.). São Paulo: Atlas, 2006.

MESQUITA, José Ignácio Botelho de. Da ação civil. São Paulo: Revista dos Tribunais, 1975.

MESQUITA, José Ignácio Botelho de. A causa petendi nas ações reivindicatórias. Teses, Estudos e Pareceres de Processo Civil. São Paulo: Revista dos Tribunais, 2005.

As novas tendências do direito processual: uma contribuição para o seu reexame. Teses, Estudos e Pareceres de Processo Civil. São Paulo: Revista dos Tribunais, 2005 , v. I.

MILARÉ, Édis. Direito do Ambiente. São Paulo: Revista dos Tribunais, 2007.

MIRRA, Álvaro Luiz Valery. Ação Civil Pública e a reparação do dano ao meio ambiente. São Paulo: Juarez de Oliveira, 2004. 
MONIZ DE ARAGÃO. Conexão e 'tríplice identidade'. Revista de Processo, 29 (1983):55.

MORI, Celso Cintra. A litispendência entre ações individuais e ações coletivas em defesa de interesses individuais homogêneos. Revista do Advogado. Ano XXIV, n. 84. São Paulo: AASP, dez. 2005.

NERY JR., Nelson e NERY, Rosa Maria de Andrade. Código de processo civil comentado e legislação processual civil extravagante. São Paulo: Revista dos Tribunais, 2003.

. O Ministério Público e as Ações Coletivas. In Ação Civil Pública: Lei 7.347/85 - reminiscências e reflexões após 10 anos de aplicação. MILARÉ, Édis (Coord.). São Paulo: Revista dos Tribunais, 1995.

NEVES, Celso. Estrutura fundamental do processo civil: tutela jurídica processual, ação, processo e procedimento. Rio de Janeiro: Forense, 1997.

OLIVEIRA, Bruno Silveira de. Conexidade e efetividade processual. São Paulo: Revista dos Tribunais, 2007.

PARÁ FILHO, Tomás Francisco de Madureira. Estudo sobre a conexão de causas no processo civil. São Paulo: Revista dos Tribunais, 1964.

PINTO, Junior Alexandre Moreira. A causa petendi e o contraditório. São Paulo: Revista dos Tribunais, 2007.

PIZZOL, Patrícia Miranda. A competência no processo civil. São Paulo: Revista dos Tribunais, 2003.

ROCHA, Ibraim. Litisconsórcio, efeitos da sentença e coisa julgada nas ações coletivas. Rio de Janeiro: Forense, 2002. 
RODRIGUES, Marcelo Abelha. Ação Civil Pública e Meio Ambiente. Rio de Janeiro: Forense Universitária, 2004.

SALleS, Carlos Alberto de. Legitimação do Ministério Público para defesa de direitos e garantias constitucionais. Dissertação (Mestrado). 30.11.1992. Orientador: Prof. Dr. Kazuo Watanabe. São Paulo, 1992. Faculdade de Direito, Universidade de São Paulo.

- Execução judicial de obrigação de fazer e não fazer em matéria ambiental. 24.06.1998. Tese (Doutorado). Orientador: Prof. Dr. Kazuo Watanabe. São Paulo, 1998. Faculdade de Direito, Universidade de São Paulo.

- Execução Judicial em Matéria Ambiental. São Paulo: Revista dos Tribunais, 1998.

(Org.). Processo Civil e Interesse Público: o processo como instrumento de defesa social. São Paulo: Revista dos Tribunais, 2003.

(Org.). Rumo a um novo Código Brasileiro de Processos Coletivos: documentos básicos para análise e discussão. Santos: Programa de Mestrado da Universidade Católica de Santos, 2005.

. Execução específica e Ação Civil Pública. In Ação Civil Pública após 20 anos - efetividade e desafios. MILARÉ, Édis. (Coord.). São Paulo: Revista dos Tribunais, 2005.

, SILVA, Solange Teles da, NUSDEO, Ana Maria de Oliveira (Orgs.). Processos coletivos e tutela ambiental. Santos: Editora Universitária Leopoldianum, 2006.

SCARPINELLA BUENO, Cassio. Conexão e continência entre ações de Improbidade Administrativa (Lei 8.429, de 1992, art. 17, $\S 5^{\circ}$ ). In Improbidade Administrativa - questões polêmicas e atuais. SCARPINELLA BUENO, Cassio e PORTO FILHO, Pedro Paulo de Rezende (Coords.). São Paulo: Malheiros, 2003. 
SCHAWB, Karl Heinz. El objeto litigioso en el processo civil. BANZHAF, Tomas (Trad.). Buenos Aires: Ediciones Jurídicas Euopa-America, 1968.

SILVA, Bruno Freire. A ineficácia da tentativa de limitação territorial dos efeitos da coisa julgada na ação civil pública. In Processo Civil Coletivo. MAZZEI, Rodrigo, NOLASCO, Rita Dias (COords.). São Paulo: Quartier Latin, 2005.

SILVA, Edward Carlyle. Conexão de causas. São Paulo: Revista dos Tribunais, 2006.

SILVA, José Afonso da. Ação Popular Constitucional. São Paulo: Revista dos Tribunais, 1978.

THEODORO JR., Humberto. Curso de direito processual civil. São Paulo: Malheiros, 2002.

UICN - União Internacional para Conservação da Natureza, PNUMA - Programa das Nações Unidas para o Meio Ambiente e WWF - Fundo Mundial para a Natureza. Cuidando do Planeta Terra: uma estratégia para o futuro da vida. São Paulo: Governo do Estado de São Paulo/SP, ECO 92, 1991.

VENTURI, Elton. Processo Civil Coletivo. São Paulo: Malheiros, 2007.

VIGLIAR, José Marcelo de Menezes. A Lei 9.494, de 10 de setembro de 1997, e a nova disciplina da coisa julgada nas ações coletivas: inconstitucionalidade. Revista dos Tribunais, 745, nov. 1997, ano 86.

. Tutela jurisdicional coletiva. São Paulo: Atlas, 1998.

. A causa de pedir e os interesses individuais homogêneos. In Causa de pedir e pedido no processo civil. CRUZ E TUCCI, José Rogério, BEDAQUE, José Roberto dos Santos (Coords.). São Paulo: Revista dos Tribunais, 2002. 
VIGORITI, Vincenzo. Interessi coletivi e processo: La legittimazione ad agire. Milão: Giuffrè, 1979.

VIOLIN, Jordão. Ação Coletiva Passiva. Salvador: Podium, 2008.

WAMBIER, Teresa Arruda Alvim. Apontamentos sobre as ações coletivas. Revista de Processo, São Paulo, ano 19, n. 75, jul.-set. 1994.

. Litispendência em ações coletivas. In Processo Civil Coletivo. MAZZEI, Rodrigo e NOLASCO, Rita Dias (Coords.). São Paulo: Quartier Latin, 2005, p. 280/295.

. Litispendência em ações coletivas. In Tutela Coletiva - 20 anos da Lei da Ação Civil Pública e do Fundo de Defesa de Direitos Difusos e 15 anos do Código de Defesa do Consumidor. LUCON, Paulo Henrique dos Santos (Coord.). São Paulo: Atlas, 2006, p. 263/278.

WATANABE, Kazuo. Tutela jurisdicional dos interesses difusos: a legitimação para agir. A tutela dos interesses difusos. GRINOVER, Ada Pellegrini (org.). São Paulo: Max Limonad, 1984.

. Demandas Coletivas e os problemas emergentes da práxis forense. Revista de Processo, n. 67, jul./set. 1992, p. 15/25.

- Relação entre demanda coletiva e demandas individuais. In Direito Processual Coletivo e o Anteprojeto de Código Brasileiro de Processos Coletivos. GRINOVER, Ada Pellegrini, MENDES, Aluisio Gonçalves de Castro e WATANABE, Kazuo (Coords.). São Paulo: Revista dos Tribunais, 2007, p. 156/160.

YARSHELL, Flávio Luiz. Tutela jurisdicional específica nas obrigações de declaração de vontade. São Paulo: Malheiros, 1993.

. Tutela jurisdicional. São Paulo: Atlas, 1998. 
ZANZUCCHI, Marco Túlio. Nuove demande, nuove prove in appello. Milão, Giuffrè, 1916.

ZAVASCKI, Teori Albino. Ação Civil Pública: competência para a causa e repartição de atribuições entre os órgãos do Ministério Público. Tutela Coletiva: 20 anos da Lei da Ação Civil Pública e do Fundo de Defesa dos Direitos Difusos, 15 anos do Código de Defesa do Consumidor / coord. - LUCON, Paulo Henrique dos Santos. São Paulo: Atlas, 2006.

. Tutela de Direitos Coletivos e Tutela Coletiva de Direitos. São Paulo: Revista dos Tribunais, 2008. 